\author{
UNIVERSIDADE DE SÃO PAULO \\ FACULDADE DE CIÊNCIAS FARMACÊUTICAS \\ Programa de Pós-Graduação em Tecnologia Bioquímico- \\ Farmacêutica \\ Área de Tecnologia Químico-Farmacêutica
}

\title{
Preparação, avaliação físico-química e biológica in vitro de pericárdio bovino conjugado com fibroína de seda/quitosana via liofilização e irradiação
}

\author{
Roberta Polak
}

Dissertação para obtenção do grau de MESTRE

Orientador:

Prof. Dr. Ronaldo N. M. Pitombo

São Paulo

2010 


\title{
Roberta Polak
}

Preparação, avaliação físico-química e biológica in vitro de pericárdio bovino conjugado com fibroína de seda/quitosana via liofilização e irradiação

\author{
Comissão Julgadora \\ da \\ Dissertação para obtenção do grau de Mestre
}

Prof. Dr. Ronaldo N. M. Pitombo

Orientador/Presidente

$1^{\circ}$. examinador

$2^{\circ}$. examinador

São Paulo, de 


\section{Dedicatória}

Dedico este trabalho à minha família e ao meu namorado, Leandro, que sempre me apoiaram e me incentivaram a seguir meus sonhos. 


\section{AGRADECIMENTOS}

Ao meu orientador Professor Ronaldo N. M. Pitombo pela grande oportunidade e pela orientação.

Aos meus pais, Rosa e Damazio, por sempre terem incentivado minha formação e sempre respeitaram minhas decisões.

Aos meus irmãos, Kate e Neto, pelo apoio e amizade.

Aos meus padrinhos, Clais e Elcio, por todo o apoio, incentivo e carinho.

Ao meu namorado, Leandro, por todas as conversas, amizade, apoio e companheirismo.

Aos meus colegas de laboratório Virgílio e Camila, que sempre estiveram dispostos a me ajudar e contribuir com o meu trabalho.

À Dra. Olga Z. Higa e Dra. Andrea C. D. Rodas do CB-IPEN/SP pelos testes de citotoxicidade e ensaios de biofuncionalidade e por toda a contribuição para meu crescimento intelectual e científico.

À Beth e ao Carlos do CTR-IPEN/SP, por sempre estarem dispostos a me ajudarem e por realizarem as irradiações por feixe de elétrons.

Ao Dennis Chicoma Lara, por todas as análises de espectroscopia Raman, e ao Professor Reinaldo Giudici da Escola Politécnica, Departamento de Engenharia Química - Universidade de São Paulo.

Às minhas queridas amigas Milena, Karine e Janaína por todas as colaborações científicas e conversas.

Ao Professor Bronislaw Polakiewicz pela ajuda com a quitosana e fibroína de seda.

À Raquel F. Weska e Dra. Marisa M. Beppu da UNICAMP/SP pela ajuda com os ensaios de calcificação.

Aos técnicos Nildemar e Celso, CCTM-IPEN/SP pelos recobrimentos com ouro para realização dos testes de microscopia eletrônica de varredura.

Aos funcionários Ivani, Alexandre, Mirian, Elza, Nilton, Elaine, Jorge e especialmente ao Juarez por toda atenção e auxílio.

Ás minhas colegas Roberta e Fabiana e ao Professor Luiz Antonio Gioielli pela ajuda com as análises térmicas.

À Yasko Kodama e Dra. Luci D. B. Machado IPEN-CNEN/SP, pela colaboração com as análises térmicas e por toda atenção e ajuda. 
A todos meus colegas de trabalho, Ana Carolina, Ana Lúcia, Ana Paula Espirito Santo, Cristina, Cíntia, Daniel, Bruno, Regina, Estela, Adelaida, Tatiane, Marco e Carolina Santos pela convivência diária e momentos de alegria compartilhados.

Ao técnico Alexander Seixas de Souza por sua assistência com as análises de microscopia confocal e ao Dr. Toshie Kawano do Laboratório de Parasitologia do Instituto Butantan.

À Simone Jared e Marta M. Antoniazzi pelas análises de Microscopia eletrônica de transmissão do Laboratório de Biologia Celular do Instituto Butantan.

À Fundação de Amparo à Pesquisa do Estado de São Paulo, pelo apoio Financeiro para a realização desta pesquisa.

E a todos os que não foram citados, mas que estão cientes de sua participação direta ou indireta na realização deste trabalho. 


\section{Resumo}

POLAK, R. Preparação, avaliação físico-química e biológica in vitro de pericárdio bovino conjugado com fibroína de seda/quitosana via liofilização e irradiação. São Paulo. 2010. Dissertação (Mestrado) - Faculdade de Ciências Farmacêuticas, Universidade de São Paulo.

Neste trabalho, a irradiação por feixe de elétrons foi estudada como uma ferramenta para a reticulação do tecido de pericárdio bovino (PB). A conjugação de quitosana e fibroína de seda no tecido de PB liofilizado também foi objeto de estudo deste trabalho. Para isto, amostras de PB foram liofilizadas e irradiadas em um acelerador de elétrons utilizando-se diferentes doses e taxas de dose. Essas amostras foram analisadas por calorimetria exploratória diferencial (DSC), análises termogravimétricas (TGA), espectroscopia Raman, teste de intumescimento, microscopia eletrônica de varredura (MEV), microscopia eletrônica de transmissão (MET), testes de tração e quanto sua biofuncionalidade. Após as análises foi possível concluir que a irradiação do tecido na ausência de oxigênio favorece a reticulação das fibras de colágeno, enquanto na presença de oxigênio observou-se preferencialmente a cisão das fibras de colágeno. Ambas as amostras apresentaram diminuição de suas propriedades mecânicas. Também pôde-se concluir que a irradiação tanto na ausência quanto na presença de oxigênio produz um novo biomaterial cuja adesão e proliferação de células endoteliais é favorecida ao longo do tecido. Na segunda etapa deste trabalho amostras de PB liofilizadas foram incorporadas em soluções de quitosana, fibroína de seda e suas misturas $(1: 3,1: 1,3: 1)$. Depois de modificadas, as amostras foram novamente liofilizadas e submetidas à irradiação. Estas amostras foram caracterizadas por espectroscopia Raman, e avaliadas quanto sua citotoxicidade, biofuncionalidade e potencial de calcificação. Após lavagens das amostras de biomaterial com solução aquosa ( $\mathrm{NaCl}$ 0,9\%), as mesmas não apresentaram toxicidade. O teste de biofuncionalidade mostrou que as amostras de PQSFI (todas as proporções) favoreceram a adesão e crescimento das células endoteliais. Todas as amostras induziram a calcificação, entretanto apresentaram uma relação $\mathrm{Ca} / \mathrm{P}$ menor do que a da hidroxiapatita.

Palavras-chaves: Pericárdio bovino; Radiação ionizante; Quitosana; Fibroína de seda; Liofilização. 


\begin{abstract}
POLAK, R. Preparation, physico-chemical and biological in vitro evaluation of bovine pericardium combined with silk fibroin/chitosan via freeze-drying and irradiation. São Paulo. 2010. (Master of Science) - Faculty of Pharmaceutical Sciences, University of São Paulo.

In this work, electron beam irradiation was studied as a crosslinker of bovine pericardium tissue (BP). The treatment of BP with chitosan and silk fibroin was also the goal of this study. Samples of BP were freeze-dried and irradiated in an electron beam accelerator using different doses and dose rates. Samples were analyzed by differential scanning calorimetry (DSC), thermogravimetric analysis (TGA), Raman spectroscopy, water uptake tests, scanning electron microscopy (SEM), transmission electron microscopy (TEM), tensile tests and evaluation as biofunctionality. After analysis, it was concluded that irradiation of the tissue in the absence of oxygen promotes crosslinking of collagen fibers. On the other hand, in the presence of oxygen the chain scission of the collagen fibers was observed, and both samples suffered a decrease in their mechanical properties. It was also concluded that irradiation, both in the absence or presence of oxygen, promotes the adhesion and proliferation of endothelial cells throughout the tissue. In the second part of this work, lyophilized BP were incorporated into chitosan, silk fibroin solutions and mixtures of chitosan/silk fibroin in the ratio of $1: 3,1: 1,3: 1$. Then, the samples were again lyophilized and submitted to irradiation. These samples were characterized by Raman spectroscopy, and tested for their cytotoxicity, biofunctionality, and calcification. After washing the biomaterial with aqueous solution ( $\mathrm{NaCl} 0.9 \%$ ), the samples did not show cytotoxicity. Biofunctionality test showed that PQSFI samples (all proportions) promoted the adhesion and growth of endothelial cells. All samples induced calcification, but they exhibited a $\mathrm{Ca} / \mathrm{P}$ ratio lower than hydroxyapatite.
\end{abstract}

Keywords: Bovine pericardium; lonizing radiation; Chitosan; Silk fibroin; Freezedrying. 


\section{SUMÁRIO}

LISTA DE FIGURAS

LISTA DE TABELAS

LISTA DE NOMENCLATURAS E SIGLAS

1. INTRODUÇÃO

2. REVISÃO BIBLIOGRÁFICA 02

2.1. Biomateriais 02

2.2. Aplicação do pericárdio bovino (PB) em biomateriais 04

2.3. Colágeno 06

2.4. Liofilização 07

2.5. Radiação ionizante 09

2.6. Aplicação de radiação ionizante em proteínas 13

2.7. Fibroína de seda (SF) 14

$\begin{array}{ll}\text { 2.8. Quitosana (Q) } & 18\end{array}$

3. OBJETIVOS 19

3.1. Objetivos gerais 19

3.2. Objetivos específicos 19

4. MATERIAL E MÉTODOS 20

4.1. Obtenção do pericárdio bovino 20

4.2. Liofilização do pericárdio bovino 20

4.3. Irradiação do PB 20

4.4. Calorimetria exploratória diferencial (DSC) 22

4.5. Análise termogravimétrica (TGA) 22

4.6. Espectroscopia Raman 23

4.7. Microscopia eletrônica de varredura (MEV) 23

4.8. Teste de intumescimento 23

4.9. Testes de tração 24

4.10. Microscopia eletrônica de transmissão (MET) 24

4.11. Quitosana (Q) 25

4.11.1. Preparo da solução de quitosana a 1 e $2 \%$

4.11.2. Preparo da N-succinil-quitosana a $2 \% \quad 26$

4.12. Fibroína de seda 26

4.12.1. Remoção da sericina 26 
4.12.2. Preparação da suspensão de fibroína a $2 \%$

4.13. Congelamento e liofilização para modificações do PB com fibroína de seda e quitosana

4.14. Determinação do intumescimento com soluções de fibroína de seda e quitosana

4.15. Microscopia ótica acoplada à liofilização

4.16. Modificação com quitosana, fibroína de seda e suas misturas

4.17. Teste de citotoxicidade 30

4.18. Teste de biofuncionalidade 31

4.19. Teste de calcificação 33

5. RESULTADOS E DISCUSSÃO 36

5.1. Efeitos da irradiação por feixe de elétrons no PB liofilizado 36

5.1.1. Determinação da temperatura de transição vítrea $(\mathrm{Tg}) \quad 36$

5.1.2. Caracterização das amostras irradiadas por espectroscopia vibracional Raman 38

5.1.3. Teste de intumescimento 41

5.1.4. Microscopia eletrônica de varredura (MEV) 43

5.1.5. Teste de intumescimento para amostras irradiadas sob vácuo

5.1.6. Microscopia eletrônica de varredura das amostras irradiadas sob vácuo 50

5.1.7. Análise termogravimétrica 55

5.1.8. Determinação da temperatura de encolhimento 59

5.1.9. Teste de tração 65

5.1.10. Microscopia eletrônica de transmissão (MET) 67

5.1.11. Teste de biofuncionalidade in vitro 68

5.2. Modificações do tecido de PB com soluções de quitosana e fibroína de seda $\quad 72$

5.2.1. Determinação dos parâmetros de modificação com as soluções de $Q, S F$ e suas misturas utilizando-se o teste de intumescimento 72

5.2.2. Determinação da temperatura de colapso das soluçoes 74 
de $Q$, SF e suas misturas

5.2.3. Caraterização das amostras via espectroscopia vibracional Raman

5.2.4. Avaliação da citotoxicidade 88

5.2.5. Avaliação quanto à biofuncionalidade 94

5.2.6. Ensaios de calcificação in vitro 98

6. CONCLUSÕES 106

7. PROPOSTAS PARA TRABALHOS FUTUROS 107

8. REFERÊNCIAS BIBLIOGRÁFICAS 108 ANEXOS 


\section{LISTA DE FIGURAS}

Figura 1. Válvula de pericárdio bovino.

Figura 2. Estrutura do colágeno, (a) cadeia alfa, (b) três cadeias alfa interligadas em tripla hélice, (c) molécula de colágeno (tropocolágeno); (d) moléculas de colágeno alinhadas de modo a formar estrutura fibrilar. 07

Figura 3. Estrutura secundária de fibroína de seda - folha- $\beta$ antiparalela.

Figura 4. Estrutura química da quitosana.

Figura 5. Acelerador de elétrons JOB/88 (IPEN).

Figura 6. Corpo de prova para teste de tração; medidas em mm.

Figura 7. Etapas envolvidas na preparação da suspensão de SF.

Figura 8. Esquema da preparação de amostras para adesão de células endoteliais.

Figura 9. Análise de DSC do tecido de pericárdio bovino liofilizado e não irradiado.

Figura 10. Espectro Raman das principais estruturas do PB. Amostras de pericárdio bovino liofilizado e irradiado na dose de 12,5 kGy e em diferentes taxas de dose.

Figura 11. Espectro Raman das principais estruturas do PB. Amostras de pericárdio bovino liofilizado e irradiado na dose de $25 \mathrm{kGy}$ e em diferentes taxas de dose.

Figura 12. Cinética de intumescimento das amostras de PB liofilizadas e irradiadas na presença de oxigênio utilizando uma taxa de dose de 4,67 kGy/s.

Figura 13. Micrografias referentes ao lado rugoso das amostras liofilizadas e irradiadas com uma taxa de dose de 4,67 kGy/s, na presença de oxigênio, utilizando-se o aumento de 500 vezes. As principais alterações do tecido estão indicadas por setas.

Figura 14. Micrografias referentes ao lado rugoso das amostras de PB liofilizadas e irradiadas na presença de oxigênio obtidas por MEV. (A) referente à amostra irradiada na dose de 20,83 kGy com aumento de 1.500 vezes. (B) - referente à amostra irradiada na dose de 31,25 kGy com aumento de 7.000 vezes. As principais alterações do tecido estão indicadas por setas. 
Figura 15. Micrografias referentes ao lado liso das amostras liofilizadas e irradiadas na presença de oxigênio obtidas por MEV, utilizando-se o aumento de 500 vezes. As principais alterações do tecido estão indicadas por setas.

Figura 16. Cinética de intumescimento das amostras de PB liofilizadas e irradiadas à vácuo utilizando-se duas doses (12,5 e 25 kGy) diferentes para cada taxa de dose aplicada (4,67; 9,34 e 28,03 kGy/s).

Figura 17. Cinética de intumescimento das amostras de PB liofilizadas e irradiadas à vácuo, utilizando-se uma taxa de dose de 4,67 kGy/s e cinco diferentes doses de irradiação (6,25; 12,5; 20,83; 25 e 31,25 kGy).

Figura 18. Micrografias referentes ao lado rugoso das amostras liofilizadas e irradiadas sob vácuo utilizando-se uma taxa de dose de 4,67 kGy/s, utilizando-se aumento de 500 vezes. As principais alterações no tecido estão indicadas por setas.

Figura 19. Micrografias referentes ao lado rugoso das amostras liofilizadas e irradiadas sob vácuo obtidas por MEV, utilizando-se aumento de 500 vezes. As principais alterações no tecido estão indicadas por setas.

Figura 20. Micrografias referentes ao lado liso das amostras liofilizadas e irradiadas com taxa de dose de 4,67 kGy/s, utilizando-se aumento de 500 vezes. As principais alterações no tecido estão indicadas por setas.

Figura 21. Micrografias referentes ao lado liso das amostras liofilizadas e irradiadas de PB obtidas por MEV, utilizando-se o aumento de 500 vezes. As principais alterações no tecido estão indicadas por setas.

Figura 22. Curvas termogravimétricas e respectivas derivadas das amostras de PB não irradiado e PB irradiado na dose de 12,5 kGy, taxa de dose de 4,67 kGy/s.

Figura 23. Curvas termogravimétricas e respectivas derivadas das amostras de PB não irradiado e PB irradiado na dose de 25 kGy, taxa de dose de 4,67 kGy/s.

Figura 24. Curvas termogravimétricas e respectivas derivadas das amostras de PB não irradiado e PB irradiado na dose de 12,5 kGy, taxa de dose de 9,34 kGy/s. 
Figura 25. Curvas termogravimétricas e respectivas derivadas das amostras de PB não irradiado e PB irradiado na dose de 25 kGy, taxa de dose de 9,34 kGy/s.

Figura 26. Curva de DSC do PB liofilizado e não irradiado. A linha pontilhada representa sua derivada.

Figura 27. Curva de DSC do PB liofilizado e irradiado na dose de 12,5 kGy, taxa de dose de 4,67 kGy/s com oxigênio. A linha pontilhada representa sua derivada.

Figura 28. Curva de DSC do PB liofilizado e irradiado na dose de 25 kGy, taxa de dose de 4,67 kGy/s com oxigênio. A linha pontilhada representa sua derivada.

Figura 29. Curva de DSC do PB liofilizado e irradiado na dose de 12,5 kGy, taxa de dose de 9,34 kGy/s com oxigênio. A linha pontilhada representa sua derivada.

Figura 30. Curva de DSC do PB liofilizado e irradiado na dose de 25 kGy, taxa de dose de 9,34 kGy/s com oxigênio. A linha pontilhada representa sua derivada.

Figura 31. Curva de DSC do PB liofilizado e irradiado na dose de 12,5 kGy, taxa de dose de 4,67 kGy/s sem oxigênio. A linha pontilhada representa sua derivada.

Figura 32. Curva de DSC do PB liofilizado e irradiado na dose de 25 kGy, taxa de dose de 4,67 kGy/s sem oxigênio. A linha pontilhada representa sua derivada.

Figura 33. Curva de DSC do PB liofilizado e irradiado na dose de 12,5 kGy, taxa de dose de 9,34 kGy/s sem oxigênio. A linha pontilhada representa sua derivada.

Figura 34. Curva de DSC do PB liofilizado e irradiado na dose de 25 kGy, taxa de dose de 9,34 kGy/s sem oxigênio. A linha pontilhada representa sua derivada.

Figura 35. Lâminas do corte semifino, coradas com azul de toluidina lado esquerdo. Micrografias obtidas por microscopia eletrônica de transmissão - lado direito. A1 e A2 - controle (0 kGy); B1 e B2 - tecido irradiado na presença de $\mathrm{O}_{2}$ (25 kGy, 4,67 kGy/s); C1 eC2 - tecido 
irradiado na ausência de $\mathrm{O}_{2}$ (25 kGy, 4,67 kGy/s). As setas brancas indicam degradação do tecido. As setas pretas indicam reticulação.

Figura 36. Imagens do PB não tratado (A), irradiado sem $\mathrm{O}_{2}(\mathrm{~B})$ e com $\mathrm{O}_{2}$ (C) após o cultivo de células endoteliais (HUVEC) in vitro. Imagens obtidas por microscopia confocal utilizando-se o comprimento de onda em $488 \mathrm{~nm}$ e $514 \mathrm{~nm}$. Os círculos mostram os pontos onde estão as células funcionais. Todas as barras de escala representam $10 \mu \mathrm{m}$.

Figura 37. Cinética de intumescimento do PB liofilizado em soluções de quitosana e fibroína de seda.

Figura 38. Microfotografias da liofilização da N-succinil-quitosana 1\% obtidas pelo Lyostat com um aumento de 100x.

Figura 39. Microfotografias da liofilização da fibroína de seda $2 \%$ obtidas pelo Lyostat com um aumento de 100x.

Figura 40. Microfotografias da liofilização solução híbrida de quitosana e fibroína de seda, ambas a $2 \%(1: 1)$, obtidas pelo Lyostat com um aumento de 100x.

Figura 41. Microfotografias da liofilização solução de quitosana $2 \%$ em solução aquosa de ácido acético $1 \%$, obtidas pelo Lyostat com um aumento de 100x.

Figura 42. Representação espectral da quitosana nativa e irradiada através da espectroscopia Raman.

Figura 43. Representação espectral da fibroína através da espectroscopia Raman.

Figura 44. Representação espectral da fibroína de seda nativa e irradiada através da espectroscopia Raman.

Figura 45. Representação espectral da fibroína de seda irradiada e tratada com etanol $70 \%$ e fibroína de seda irradiada através da espectroscopia Raman.

Figura 46. Representação espectral do pericárdio bovino através da espectroscopia Raman.

Figura 47. Representação espectral do pericárdio bovino antes (PB) e depois (PBI) da irradiação através da espectroscopia Raman.

Figura 48. Variação espectral entre a fibroína (SF) e a quitosana (Q) a 
várias concentrações (SFQ) via espectroscopia Raman.

Figura 49. Representação espectral Raman para a mistura de PB com $Q$ nativo e irradiado.

Figura 50. Representação espectral Raman do pericárdio conjugado com solução de quitosana e fibroína de seda (3:1) antes e após a irradiação.

Figura 51. Representação espectral Raman do pericárdio conjugado com solução de quitosana e fibroína de seda (1:1) antes e após a irradiação.

Figura 52. Representação espectral Raman do pericárdio conjugado com solução de quitosana e fibroína de seda (1:3) antes e após a irradiação.

Figura 53. Curva de citotoxicidade do extrato de PSF. (•) - Controle positivo; (匹) - Controle negativo; $(\diamond)$ - PSF (não irradiado); $(\triangleleft)$ - PSFI (irradiado).

Figura 54. Curva de citotoxicidade do extrato de PQ. (•) - Controle

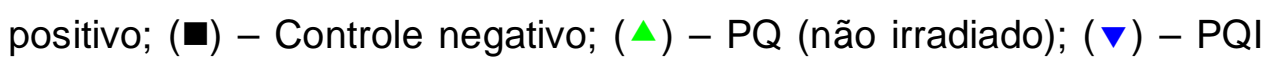
(irradiado).

Figura 55. Curva de citotoxicidade do extrato de PQSF (3:1). (•) Controle positivo; (匹) - Controle negativo; ( $\star$ ) - PQSF (não irradiado); $(\triangleright)$ - PQSFI (irradiado).

Figura 56. Curva de citotoxicidade do extrato de PQSF (1:1). (•) Controle positivo; (匹) - Controle negativo; (O) - PQSF (não irradiado); $(\diamond)-$ PQSFI (irradiado).

Figura 57. Curva de citotoxicidade do extrato de PQSF (1:3). (•) Controle positivo; (匹) - Controle negativo; ( $\nabla)$ - PQSF (não irradiado); (-) - PQSFI (irradiado).

Figura 58. Viabilidade das células $\mathrm{CHO}(\%)$ nos extratos $(100 \%)$ do pericárdio bovino tratado com quitosana, fibroína de seda e mistura de quitosana/fibroína de seda.

Figura 59. Viabilidade das células $\mathrm{CHO}(\%)$ nos extratos (100\%) do pericárdio bovino tratado com quitosana, fibroína de seda e misturas de quitosana/fibroína de seda, após lavagens. 
Figura 60. Imagens tridimensionais obtidas após o cultivo de células endoteliais no $P Q$ não irradiado (superior) e irradiado (inferior). Todas as barras de escala em $10 \mu \mathrm{m}$.

Figura 61. Imagens tridimensionais obtidas após o cultivo de células endoteliais no PSF não irradiado (superior) e irradiado (inferior). Todas as barras de escala em $10 \mu \mathrm{m}$.

Figura 62. Imagens tridimensionais obtidas após o cultivo de células endoteliais no PQSF 3:1 não irradiado (superior) e irradiado (inferior). Os círculos indicam as células aderidas e viáveis no tecido. Todas as barras de escala em $10 \mu \mathrm{m}$.

Figura 63. Imagens tridimensionais obtidas após o cultivo de células endoteliais no PQSF 1:1 não irradiado (superior) e irradiado (inferior). Os círculos indicam as células aderidas e viáveis no tecido. Todas as barras de escala em $10 \mu \mathrm{m}$.

Figura 64. Imagens tridimensionais obtidas após o cultivo de células endoteliais no PQSF 1:3 não irradiado (superior) e irradiado (inferior). Os círculos indicam as células aderidas e viáveis no tecido. Todas as barras de escala em $10 \mu \mathrm{m}$.

Figura 65. Imagens da superfície da amostra de PB obtidas por MEV (acima) e espectro gerado por EDS (abaixo) após ensaio de calcificação. Círculo azul = P; círculo vermelho = Ca.

Figura 66. Imagens da superfície da amostra de PQ obtidas por MEV (acima) e espectro gerado por EDS (abaixo) após ensaio de calcificação. Círculo azul = P; círculo vermelho = Ca.

Figura 67. Imagens da superfície da amostra de PSF obtidas por MEV (acima) e espectro gerado por EDS (abaixo) após ensaio de calcificação. Círculo azul = P; círculo vermelho = Ca.

Figura 68. Imagens da superfície da amostra de PQSF 1:3 obtidas por MEV (acima) e espectro gerado por EDS (abaixo) após ensaio de calcificação. Círculo azul = P; círculo vermelho = Ca.

Figura 69. Imagens da superfície da amostra de PQSF 1:1 obtidas por MEV (acima) e espectro gerado por EDS (abaixo) após ensaio de calcificação. Círculo azul = P; círculo vermelho = Ca. 
Figura 70. Imagens da superfície da amostra de PQSF 3:1 obtidas por MEV (acima) e espectro gerado por EDS (abaixo) após ensaio de calcificação. Círculo azul = P; círculo vermelho $=\mathrm{Ca}$.

Figura 71. Imagens da superfície da amostra de PQI obtidas por MEV (acima) e espectro gerado por EDS (abaixo) após ensaio de calcificação. Círculo azul = P; círculo vermelho $=\mathrm{Ca}$.

Figura 72. Imagens da superfície da amostra de PSFI obtidas por MEV (acima) e espectro gerado por EDS (abaixo) após ensaio de calcificação. Círculo azul $=\mathrm{P}$; círculo vermelho $=\mathrm{Ca}$.

Figura 73. Imagens da superfície da amostra de PQSFI 3:1 obtidas por MEV (acima) e espectro gerado por EDS (abaixo) após ensaio de calcificação. Círculo azul = P; círculo vermelho $=\mathrm{Ca}$.

Figura 74. Imagens da superfície da amostra de PQSFI 1:3 obtidas por MEV (acima) e espectro gerado por EDS (abaixo) após ensaio de calcificação. Círculo azul $=\mathrm{P}$; círculo vermelho $=\mathrm{Ca}$.

Figura 75. Imagens da superfície da amostra de PQSFI 1:1 obtidas por MEV (acima) e espectro gerado por EDS (abaixo) após ensaio de calcificação. Círculo azul = P; círculo vermelho $=\mathrm{Ca}$. 


\section{LISTA DE TABELAS}

Tabela 1. Doses e taxas efetivas aplicadas no tecido de pericárdio bovino.

Tabela 2. Composição do SBF $1 \times$ e SBF 1.5 ×.

Tabela 3. Média dos valores de Tg obtidos por DSC.

Tabela 4. Perda de massa das três etapas obtidas por TGA.

Tabela 5. Temperatura de encolhimento do PB irradiado sob vácuo.

Tabela 6. Dados obtidos pelo teste de tração das amostras irradiadas na presença e ausência de oxigênio.

Tabela 7. Resultados obtidos pela microscopia óptica acoplada a um módulo de liofilização.

Tabela 8. Atribuições de banda no espectro Raman da SF liofilizada e tratada com etanol.

Tabela 9. Atribuições de banda no espectro Raman do pericárdio bovino. 


\section{LISTA DE NOMENCLATURAS E SIGLAS}

$\Delta \mathbf{H} \quad$ Energia de entalpia $(\mathrm{J} / \mathrm{g})$

$\mu \mathrm{m} \quad$ Micrômetros

$\delta$-NH Estiramento da ligação $\mathrm{NH}$

$\sigma_{\text {rup }} \quad$ Tensão de ruptura

${ }^{\circ} \mathbf{C} \quad$ Graus Celsius

CHO Células de ovário de Hamster Chinês (CHO-K1)

DSC Calorimetria Exploratória Diferencial

E Módulo de Young ou módulo de elasticidade

$\mathbf{e}_{\text {aq }}^{-} \quad$ Elétron aquoso

EDS Energia dispersiva de raios- $x$

GD Grau de desacetilação

Gly Glicina

HUVEC Células endoteliais provenientes de cordão umbilical humano

IC $_{50(\%)}$ Índice de Citotoxicidade - concentração do extrato da amostra que mata $50 \%$ da população de células

kDa Quliodalton

kGy QuiloGray

kGy/s QuiloGray por segundo

mA Miliamperes

MET Microscopia eletrônica de transmissão

MEV Microscopia eletrônica de varredura

MeV Megaeletrovolts

MPa Megapascal

MTS 3-(dimetiltiazol-2-il)-5-(3-carboximetoxifenil)-2-(4-sulfofenil)-2Htetrazolium 
$\mathbf{O H}^{\bullet} \quad$ Radical hidroxila

PB Pericárdio bovino

PEBD Polietileno de baixa densidade

PMS Metassulfato de fenazida

PQ Pericárdio bovino modificado com quitosana

PQI Pericárdio bovino modificado com quitosana e irradiado

PQSF Pericárdio bovino modificado com quitosana e fibroína de seda

PQSFI Pericárdio bovino modificado com quitosana, fibroína de seda e irradiação

PSF Pericárdio bovino modificado com fibroína de seda

PSFI Pericárdio bovino modificado com fibroína de seda e irradiado

Q Quitosana

$\mathbf{R}^{2} \quad$ R-quadrado

RPMI Meio de cultura para cultivo celular

SBF Simulated body fluid ou fluído corpóreo simulado

SF $\quad$ Fibroína de seda

Tg Temperatura de transição vítrea

TGA Termogravimetria 


\section{INTRODUÇÃO}

Próteses de válvulas cardíacas podem ser divididas em dois grupos: mecânicas e biológicas. As válvulas biológicas podem ser mais facilmente monitoradas e não induzem formação de coágulos, porém são menos duráveis. Tecidos biológicos têm sido utilizados desde os anos 60 como uma alternativa para a confecção de próteses mecânicas cardíacas (ARCIDIACONO; CORVI; SEVERI, 2005). A partir de 1974, o pericárdio bovino (PB) tornou-se um dos materiais mais utilizados para a preparação de biopróteses. O pericárdio é um material anisotrópico composto de fibras de colágeno e elastina incorporadas em uma matriz amorfa, composta essencialmente por proteoglicanos e ácido hialurônico. As fibras colágenas são dispostas em camadas, com diferentes direções de alinhamento em cada camada, dando origem a interessantes propriedades mecânicas do pericárdio, inclusive a capacidade de sofrer grande deformação durante a execução de funções fisiológicas (DAAR et al., 2009). O PB vem sendo utilizado desde então como material para a fabricação de próteses como as válvulas cardíacas (ORÉFICE; PEREIRA; MANSUR, 2006). Para melhorar a resistência dos materiais, vários processos de reticulação químicos e físicos foram desenvolvidos. Atualmente o método mais consolidado para biopróteses de pericárdio bovino é a reticulação com glutaraldeído (GA), embora este processo possa induzir calcificação in vivo, levando à insuficiência da válvula e a necessidade de retroca da prótese (LEIRNER; TATTINI JR.; PITOMBO, 2009). Neste trabalho, a irradiação por feixe de elétrons foi estudada como um caminho para a reticulação do tecido de PB, explorando novas oportunidades em tratamentos biomaterial introduzindo a utilização da radiação ionizante por feixe de elétrons. A irradiação por feixe de elétrons é amplamente utilizada para promover a reticulação em polímeros (polietileno, por exemplo). Os elétrons gerados pelo acelerador penetram no material e iniciam reações químicas iônicas e/ou radicalares que alteram as propriedades do material, podendo levar a formação de ligações cruzadas (crosslinks). A conjugação de quitosana e fibroína de seda no tecido de PB liofilizado também foi objeto de estudo deste trabalho, e foram utilizadas a fim de melhorar as propriedades do material. A liofilização foi utilizada como meio de facilitar a impregnação dos agentes químicos. 


\section{REVISÃO BIBLIOGRÁFICA}

\subsection{Biomateriais}

Biomateriais são materiais ou substâncias utilizadas para confeccionar dispositivos ou próteses visando a substituição de uma parte ou de uma função do corpo de uma forma segura, confiável, economicamente viável e de forma aceitável fisiologicamente. A variedade de dispositivos e materiais atualmente utilizados no tratamento de doenças ou lesões inclui itens como suturas, agulhas, cateteres, chapas, obturações dentárias, entre outras. Ao longo dos anos, várias definições do termo biomateriais têm sido propostas. Uma definição bem abrangente de biomateriais, proposta por Williams em 1987 é "qualquer substância (exceto medicamentos) ou combinação de substâncias, de origem sintética ou natural, que possa ser utilizada por qualquer período de tempo, como um todo, ou como parte de um sistema a fim de tratar, aumentar, ou substituir qualquer tecido, órgão ou função do corpo" (PARK; BRONZINO, 2003). Os biomateriais podem ser sintéticos ou de origem natural. Os sintéticos envolvem os materiais metálicos, cerâmicos, poliméricos e os compósitos. Dentre os naturais o material de maior destaque é o colágeno (ORÉFICE; PEREIRA; MANSUR, 2006).

Para a fabricação de um biomaterial deve-se possuir um conhecimento interdisciplinar ou colaborar com os indivíduos de diferentes especialidades, a fim de desenvolver biomateriais para utilização na medicina e odontologia. Durante os séculos 18 e 19 vários dispositivos metálicos foram utilizados para fixar fraturas ósseas, fios e pinos de $\mathrm{Fe}, \mathrm{Au}, \mathrm{Ag}$, e Pt.

O histórico do uso de biomateriais não se tornou prática até o advento de uma técnica cirúrgica asséptica desenvolvida pelo Dr. J. Lister em 1860. Procedimentos cirúrgicos anteriores, sejam elas envolvidas com biomateriais ou não, eram geralmente fracassadas, devido à infecção. Após este evento diversos avanços foram realizados, tais como a criação de diferentes ligas metálicas para serem utilizadas como parafusos e placas; introdução do uso de polímeros como o PMMA (polimetilmetacrilato) utilizado em substituições de 
articulações e da córnea; substituição de vasos sanguíneos; comercialização de próteses valvulares cardíacas e até a substituição total do coração. Nos últimos anos, muitos outros avanços vêm sendo realizados e a área de biomateriais vem se tornando cada vez mais promissora (RATNER et al., 2004; PARK; BRONZINO, 2003).

As tentativas de substituição de válvulas cardíacas humanas com próteses começaram cerca de quatro décadas atrás. As próteses de válvulas cardíacas podem ser amplamente classificadas em próteses mecânicas (feito de material não biológico) e biopróteses (feitas de tecido biológico) (ORÉFICE; PEREIRA; MANSUR, 2006).

As primeiras válvulas biológicas foram homoenxertos implantados com válvulas explantadas de cadáveres dentro de 48 horas após a morte. A conservação das válvulas incluía várias técnicas de esterilização, liofilização, e imersão em solução antibiótica. O uso de homoenxertos não é muito popular devido a problemas baixa duração e à limitada disponibilidade. Tentativas também foram feitas no início dos anos 1960, com o uso de xenotransplantes (fabricados a partir de válvulas de tecidos animais) e biopróteses suínas tornaram-se comercialmente disponíveis após a introdução da fixação com gluteraldeído (em vez de formaldeído, que foi inicialmente utilizada). O tecido fixado de pericárdio bovino também é utilizado para a construção de válvulas cardíacas (PARK; BRONZINO, 2003).

A vantagem das biopróteses é a que estão livres de trombo-embolia e, portanto, não requerem terapia anticoagulante em geral. Por outro lado, as válvulas bioprostéticas são propensas à calcificação e ao rompimento do folheto. Essas válvulas têm uma duração média de cerca de 10 anos e após este período devem ser substituídas. Inúmeras tentativas estão sendo feitas para melhorar o design, bem como a fixação da bioprótese, a fim de minimizar os problemas de calcificação e aumentar a duração da função do implante. Problemas comuns encontrados em válvulas mecânicas incluem: tromboembolia, falha estrutural, destruição de hemácias e plaquetas, sobrecrescimento de tecido, dano do revestimento endotelial, vazamento 
paravalvular / perivalvular, rompimento de suturas e infecção. Os problemas das válvulas bioprostéticas são: calcificação do tecido, ruptura do folheto, vazamento para e perivalvular e infecção (RATNER et al., 2004; (ORÉFICE; PEREIRA; MANSUR, 2006; PARK; BRONZINO, 2003).

\subsection{Aplicação do pericárdio bovino (PB) como biomaterial}

Próteses de tecido biológico vêm sendo utilizadas desde a década de 60 como uma alternativa para próteses cardíacas mecânicas (ARCIDIACONO; CORVI; SEVERI, 2005). A partir de 1974, o pericárdio bovino (PB) passou a ser um dos materiais mais utilizados para a confecção de biopróteses. O PB é uma membrana fibroelástica que envolve o coração, formado por três camadas: a serosa composta por células mesoteliais, a camada fibrosa composta de colágeno e fibras elásticas e o tecido conectivo com fibras colágenas e elásticas arranjadas livremente. A vantagem de se utilizar este tecido está justamente no seu elevado teor de colágeno, onde modificações podem ser realizadas nos grupamentos aminas $\left(\mathrm{NH}_{2}\right)$, carboxílicos $(\mathrm{COOH})$ e hidroxilas (OH) (ORÉFICE; PEREIRA; MANSUR, 2006). O pericárdio bovino, que é composto principalmente de colágeno tipo I (NAIMARK et al., 1992), tem sido, desde então, utilizado como material de biopróteses e para fabricação de válvulas cardíacas (COSGROVE et al., 1985) com ilustrado na Figura 1.

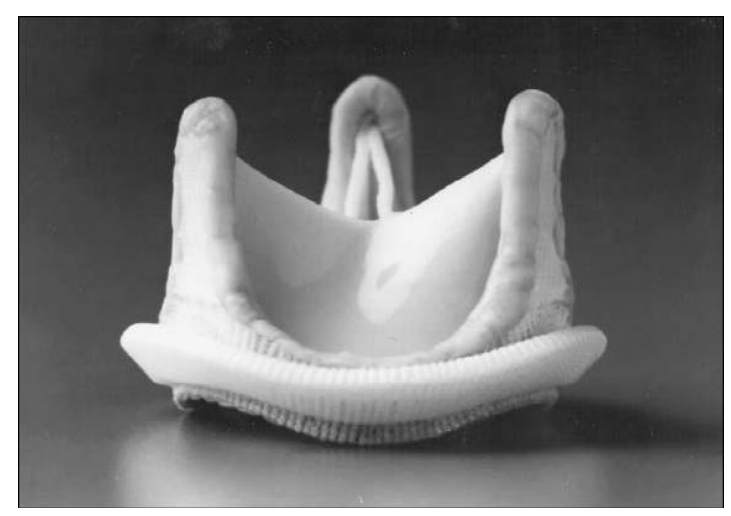

Figura 1. Válvula de pericárdio bovino (Fonte: PARK; BRONZINO, 2003). 
A calcificação, formação de fosfato de cálcio ou de outros componentes derivados do cálcio, é a principal causa de falha em biopróteses confeccionadas com pericárdio (AIMOLI et al., 2007). Alguns estudos sugerem que a calcificação provavelmente ocorre devido à alta toxicidade dos resíduos de glutaraldeído no pericárdio bovino (SCHOEN; LEVY, 2005; GENDLER; GENDLER; NIMNI, 1984; SIMIONESCU; SIMIONESCU; DEAC, 1993; ABOLHODA et al., 1996), o que também pode levar a uma interação com as células do sistema imunológico (RIEDER et al., 2006). Resíduos de células presentes no tecido de pericárdio bovino também podem contribuir para degradação desta válvula (KASIMIR et al., 2005).

Alguns trabalhos sugerem que a destoxificação do pericárdio bovino tratado com glutaraldeído pode ser realizada tratando-se o tecido com, por exemplo, ácido alfa amino oléico (GULBINS et al., 2006), ácido deoxicólico (COSTA et al., 2004), triton (GRAUSSA et al., 2005), descelularização pela ação da tripsina (GRAUSSA et al., 2005). A utilização de outros agentes para recobrimento do pericárdio também vem sendo investigada, como por exemplo, o tratamento como o ácido hialurônico e fibronectina (OHRI et al., 2004; TRANTINA-YATES et al., 2001). A utilização de outros agentes reticulantes também foram propostas como a triglicidilamina (CONNOLLY et al., 2005) e a fenetilamina diepóxido (AIMOLI et al., 2007). A liofilização do tecido tratado com glutaraldeído também parece ser bastante útil para a diminuição da toxicidade (MAIZATO et al., 2003).

A diminuição da citotoxicidade do material parece ser uma característica fundamental para a compatibilidade da válvula cardíaca. A citotoxicidade e biofuncionalidade in vitro das válvulas cardíacas pode ser avaliada através do crescimento de células endoteliais sobre elas. A capacidade de endotelização dos tecidos podem nos ajudar a prever a interação da prótese no organismo, pois naturalmente as válvulas cardíacas são recobertas por uma monocamada de células endoteliais que funcionam como uma barreira entre o sangue e o tecido. Esta barreira parece prevenir a invasão de plasma para o interior do tecido da válvula, assim como a adesão de plaquetas e fibrinogênio na sua 
superfície, fatores que têm sido sugeridos como atuantes na calcificação e degeneração da bioprótese (STARR et al., 2002; DOENST; BORGER; DAVID, 2004). A interação das células endoteliais com o PB pode ser observada por imunocitoquímica, pela visualização do fator VIII, o qual está presente no citoplasma das células endoteliais em plena atividade (JAFFE; HOYER; NACHMAN, 1973).

\subsection{Colágeno}

O colágeno é um constituinte da matriz extracelular (MEC). É a principal proteína estrutural presente nos vertebrados. O colágeno é largamente utilizado como biomaterial em suturas, tecidos, matriz para liberação controlada de drogas. O termo colágeno é aplicado para o colágeno que está presente na pele, tendão e ossos. Há mais de 19 tipos de colágeno, o principal tipo estudado é o colágeno do tipo I, pois é o mais abundante. O colágeno do tipo I contém três cadeias polipeptídicas, denominadas cadeias $\alpha$, sendo duas do tipo $\alpha_{1}$ e uma do tipo $\alpha_{2}$. São similares e homólogas e ambas se constituem de repetições do tripleto de seqüência $G l y-X-Y$, onde $X$ e $Y$ são geralmente prolina e hidroxiprolina, respectivamente. As três cadeias a estão arranjadas em triplahélice (Figura 2b). Ainda, o colágeno organiza-se em estruturas fibrilares que são estabilizadas por ligações de hidrogênio, interações eletrostáticas e hidrofóbicas. As moléculas de tropocolágeno estão deslocadas um quarto em relação à molécula adjacente, apresentando também uma região de espaçamento vazio entre duas moléculas alinhadas longitudinalmente (gap), seguidas de uma região de sobreposição (overlap) destas moléculas (Figura 2d) (MURRAY et al., 2000; LEHNINGER; NELSON; COX, 2008). 


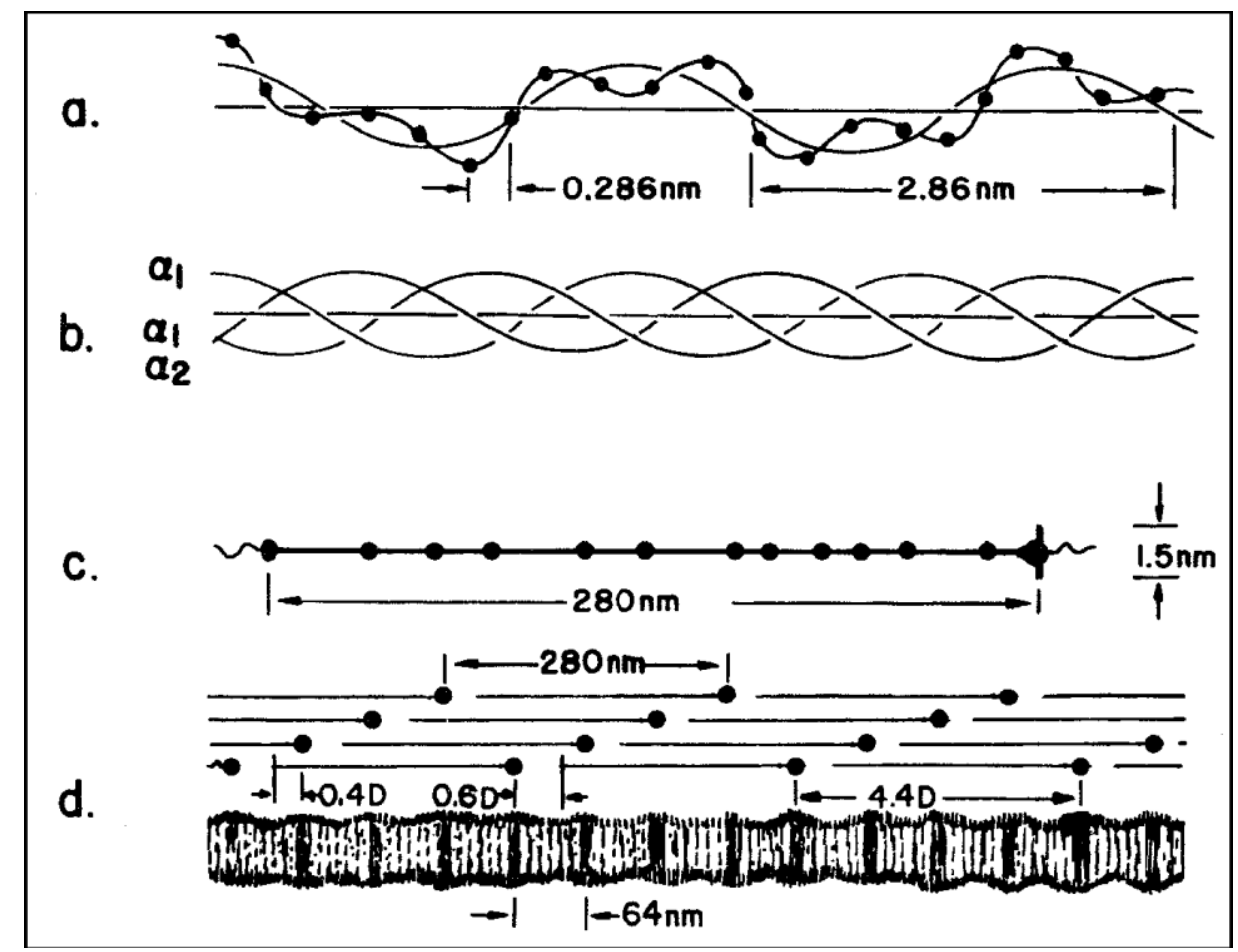

Figura 2. Estrutura do colágeno, (a) cadeia alfa, (b) três cadeias alfa interligadas em tripla hélice, (c) molécula de colágeno (tropocolágeno); (d) moléculas de colágeno alinhadas de modo a formar estrutura fibrilar (Fonte: PARK; BRONZINO, 2003).

\subsection{Liofilização}

A liofilização pode ser definida como a secagem de uma determinada substância através de seu congelamento e posterior remoção de solvente associado pela sublimação direta da fase sólida para a fase gasosa, sem passar pela fase líquida. Na maioria das vezes o solvente é a água (CAMERON, 1997).

A técnica de liofilização apresenta vantagens únicas que a diferencia das demais técnicas de secagem. Como por exemplo, a secagem de produtos farmacêuticos termolábeis. Outras vantagens são a retenção de forma, retenção de atividade, facilidade de reconstituição, aumento no tempo de prateleira, alta precisão de dose, entre outras. Entretanto como todas as técnicas, a liofilização apresenta algumas desvantagens como, por exemplo, a 
velocidade do processo, que geralmente tem duração maior de 24 horas, alto custo de investimento e de operação. Alguns exemplos de produtos de escolha a serem liofilizados são: hormônios, antibióticos, bactérias, hemoderivados, enzimas, vacinas, vitaminas, tecidos biológicos, produtos químicos de alto valor agregado, entre outros. $\mathrm{Na}$ área de alimentos a liofilização é comumente aplicada em: vegetais, chás, café, cubos de frango, frutas e space food, por exemplo (OETJEN; HASELEY, 2004).

O processo de liofilização engloba três etapas principais: o congelamento, a secagem primária e a secagem secundária. Após o congelamento a água é removida do material por sublimação (secagem primária). Em seguida a água incongelável é removida por dessorção, sob pressão reduzida (CAMERON, 1997).

O congelamento é considerado uma das etapas mais importantes do processo. Após o congelamento a estrutura, tamanho e forma do produto são fixadas. $O$ congelamento define o tamanho e a distribuição dos cristais de gelo no material, caracterizando as fases de secagem primária e secundária (PATAPOFF; OVERCASHIER, 2002; O'BRIEN et al., 2004). Se a estrutura da matriz é alterada durante a liofilização esta poderá sofrer danos e até perda do produto.

Um problema que pode ocorrer durante a liofilização é o colapso da matriz sólida. O colapso é um fenômeno que se observa em materiais que sofrem uma transição vítrea $(\mathrm{Tg})$ e ocorre na interface de liofilização quando o gelo dendrítico é sublimado do produto a uma temperatura acima da temperatura de colapso. A solução concentrada não tem viscosidade suficiente para suportar a sua própria estrutura, sem o apoio adicional do gelo. Quando o gelo puro é evaporado, o líquido viscoso flui para as cavidades na interconexão e colapsa, seguido de uma expansão devido à ebulição, levando à oclusão dos poros e impedindo a saída do vapor. O produto ganha calor sensível e cadeia usual de eventos irá ocorrer. O colapso ocorre sempre na mesma temperatura como na solidificação, embora fenomenologicamente sejam eventos distintos (CAMERON, 1997). A temperatura de colapso pode ser determinada com o 
auxílio de um microscópio acoplado a um modulo de liofilização (OETJEN; HASELEY, 2004).

O annealing é um tratamento térmico que pode ser empregado durante a etapa do congelamento a fim de conferir uma melhor homogeneidade do tamanho e da distribuição dos cristais de gelo na matriz. No annealing o produto é mantido a uma temperatura específica de congelamento (acima da Tg e abaixo da temperatura de fusão dos cristais de gelo no material) por um determinado período de tempo para permitir a reorganização dos cristais de gelo na matriz. Após, a temperatura é novamente mantida abaixo da Tg, para que durante a secagem primária não ocorra o colapso do material (HAWE; FRIESS, 2006; SEARLES; CARPENTER; RANDOLPH, 2001; ABDELWAHED; DEGOBERT; FESSI, 2006). O tecido de pericárdio bovino tratado com annealing na etapa do congelamento antes do processo de liofilização (LEIRNER; TATTINI JR.; PITOMBO, 2009) também pode ser útil para facilitar a incorporação de agentes químicos dentro do tecido.

O trabalho desenvolvido por Aimoli et al. (2007) sugere que a liofilização do tecido de pericárdio bovino, antes do tratamento químico com substâncias reticulantes parece evitar a calcificação da matriz.

\subsection{Radiação ionizante}

Radiações ionizantes ou radiação de alta energia são aquelas que ionizam diretamente ou indiretamente as moléculas do meio irradiado. As partículas que possuem carga ionizam diretamente o meio irradiado e podem ser geradas por máquinas aceleradoras de partículas, como por exemplo, os aceleradores de elétrons (CHAPIRO, 1962).

A irradiação por feixe de elétrons trata materiais com elétrons de alta energia produzidos por um acelerador a fim de causar efeitos específicos. Esta tecnologia vem sendo utilizada em diversas aplicações industriais tais como em medicamentos, cosméticos e em dispositivos farmacêuticos. Em geral a radiação pode ser classificada em dois grupos: eletromagnéticas e radiação de partículas. Os vários tipos de radiação ionizante no espectro 
eletromagnético produzem efeitos bactericidas por meio da transferência de energia de um fóton em uma ionização característica a um alvo biológico (SUGRANES, 2005).

O acelerador de elétrons transmite elétrons a velocidades elevadas. Os elétrons são emitidos de um colimador que varre todo o produto para irradiar o material. Quando os elétrons penetram no material, eles colidem com os átomos que encontram de forma randômica. Os átomos geralmente tornamse excitados ou ionizados por essas colisões, ganhando energia extra que pode iniciar alterações químicas dentro do produto. Cada feixe de elétrons tem energia suficiente para excitar os átomos do material, antes de repousarem ou ao se dispersarem fora do material (SOMESSARI et al., 2007).

A irradiação por feixe de elétrons é um modo de esterilização que possui diversas vantagens sobre as técnicas de esterilização mais populares na indústria farmacêutica, tais como a irradiação gama, óxido de etileno (ETO), calor úmido e seco. As vantagens mais relevantes são: não necessita de condicionamento de carga, baixo tempo de exposição (geralmente menos que 10 minutos), não deixa resíduos químicos, é ambientalmente amigável, rápido processamento, em geral é mais barato que outras técnicas e não há necessidade de aeração ou degaseificação após exposição. Entretanto como todas as técnicas, apresentam algumas limitações: baixa penetração (dependendo da espessura e densidade do material), uniformidade de dose, a orientação dos materiais é importante, pois pode ocorrer descoloração em alguns materiais (SUGRANES, 2006).

Os aceleradores são classificados de acordo com a energia dos elétrons produzidos: de baixa energia (até $1 \mathrm{MeV}$ ), de média energia (1 a 5 $\mathrm{MeV}$ ) e de alta energia (maior que $5 \mathrm{MeV}$ ). Os aceleradores são máquinas que utilizam energia elétrica para gerar elétrons livres, acelerá-los em altas velocidades, e direcioná-los aos materiais que passam pelo acelerador. Os elétrons penetram no material e iniciam reações químicas que alteram as propriedades do material. Os tipos de reações químicas produzidas dependem da natureza do material. A reação pode gerar polimerização (plásticos e compósitos), degradação (materiais químicos, por exemplo) e esterilização 
(rompimento de cadeia de DNA dos microrganismos) (MCGINNISS, 1985; SUGRANES, 2005).

Durante a irradiação a energia inicial é rapidamente degradada na matéria, e a maioria das alterações químicas produzidas pela irradiação é uma consequência dos produtos secundários gerados a partir de diversas reações secundárias. Uma das principais reações que podem ocorrer é a reticulação (crosslinking), bastante estudada em polímeros. Outra importante consequência da irradiação pode ser a degradação, como por exemplo, a cisão de ligações $\mathrm{C}$-C, especialmente em polímeros.

Um dos efeitos mais marcantes da radiação é o efeito exercido pelo oxigênio. Na presença do oxigênio reações acontecem que levam a formação de peróxido de hidrogênio $\left(\mathrm{H}_{2} \mathrm{O}_{2}\right)$, agente com alto potencial de degradação. Quando irradiadas em estado seco, as proteínas podem sofrer alterações nas propriedades químicas e físicas. O principal efeito da presença de oxigênio em proteínas é a oxidação dos resíduos de cistina gerando o ácido cisteico e outros produtos de oxidação. Entretanto o ataque às ligações dissulfeto não é o único efeito sobre as proteínas. Os ataques podem ocorrer em resíduos de aminoácidos aromáticos como a fenilalanina, a histidina ou tirosina. Alterações em outros resíduos de aminoácidos também ocorrem e a clivagem de ligações peptídicas pode ocorrer. Amônia e aminas são freqüentemente encontradas após a hidrólise das proteínas irradiadas (SWALLOW, 1960).

As alterações induzidas em proteínas pela irradiação em solução aquosa são inteiramente atribuídas aos ataques dos radicais livres e outras espécies reativas formadas a partir da radiólise da água. O mecanismo da irradiação de $100 \mathrm{eV}$ na água é dado abaixo:

$$
\mathrm{H}_{2} \mathrm{O} \rightarrow 2,7 \mathrm{e}_{\mathrm{aq}}^{-}+0,45 \mathrm{H}_{3} \mathrm{O}^{+}+3,2 \mathrm{OH}^{\bullet}+0,6 \mathrm{H}^{+}+0,45 \mathrm{H}_{2}+0,7
$$

Como pode ser observado, o elétron aquoso $\left(\mathrm{e}_{\text {aq }}^{-}\right)$e o radical hidroxila $\left(\mathrm{OH}^{\circ}\right)$ são os principais produtos da radiação em soluções aquosas (BUTLER et al., 1982).

Os grupamentos - $\mathrm{SH}$ presentes na proteína podem ser oxidados pela ação do radical hidroxila ou pelo peróxido de hidrogênio. Além disso, as 
ligações de dissulfetos podem ser reduzidas pela ação do elétron aquoso e hidrogênio gasoso. Alterações que envolvem ligações de dissulfeto (S-S) e ligações S-H podem ocorrer em consequência da desnaturação, como consequências primárias da irradiação. Proteínas, peptídeos e aminoácidos podem gerar amônia depois de irradiadas em solução. Peróxidos são detectados após a irradiação de proteínas em solução na presença de oxigênio (SWALLOW, 1960).

O oxigênio acrescenta-se facilmente a radicais livres e, se presente, irá desempenhar papel nas reações induzidas pela irradiação. O oxigênio molecular possui dois elétrons desemparelhados em seu estado fundamental e se comporta como um birradical, reagindo com outros radicais e tripletos no estado excitado (que também possuem dois elétrons desemparelhados). $O$ íon superóxido $\left(\mathrm{O}_{2}{ }^{-}\right)$é um importante intermediário quando o sistema aquoso é irradiado na presença de oxigênio. É produzido pela reação de oxigênio com o elétron aquoso $\left(e^{-}{ }_{a q}\right)$.

$$
\mathrm{e}_{\mathrm{aq}}^{-}+\mathrm{O}_{2} \rightarrow \mathrm{O}_{2}^{-}
$$

O íon superóxido possui um elétron desemparelhado e é um radical livre muito reativo, consequentemente na presença de algum composto orgânico, ele gera outros produtos.

A reação do oxigênio molecular com radicais orgânicos gera radicais peroxilas, relativamente estáveis. Conseqüentemente, esses radicais peroxilas são menos reativos e possuem um maior tempo de vida.

$$
\mathbf{R}^{\bullet}+\mathrm{O}_{2} \rightarrow \mathrm{RO}_{2}^{\bullet} \text { (radical peroxila) }
$$

Os radicais peroxilas podem reagir com moléculas orgânicas através da abstração de hidrogênio gerando o hidroperóxido $\left(\mathrm{RO}_{2} \mathrm{H}\right)$ e um radical orgânico.

$$
\mathrm{RO}_{2}^{\bullet}+\mathbf{R H} \rightarrow \mathrm{RO}_{2} \mathrm{H}+\mathbf{R}^{\bullet}
$$

Estas duas últimas reações constituem uma reação em cadeia, que será responsável pela autoxidação de materiais orgânicos (WOODS, 1994). 


\subsection{Aplicação de radiação ionizante em proteínas}

As proteínas contêm diferentes funções orgânicas como, aminas, amidas, hidroxilas, tióis e grupos carboxílicos que podem sofrer reações químicas, e conseqüentemente formar ligações cruzadas. A reticulação de proteínas é bastante importante na indústria do couro (LABANA, 1985) e vem sendo bastante estudada em membranas de colágeno (FRIESS, 1998) e tecido de pericárdio bovino e porcino (AIMOLI et al., 2007; JORGE-HERRERO; GARCÍA PÁEZ; DEL CASTILLO-OLIVARES RAMOS, 2005) para aplicações como biomateriais.

A degradação pode ser causa do aumento do grau de intumescimento ou de solubilidade do colágeno (BAILEY; TROMANS, 1964; SWALLOW, 1960).

Quanto às propriedades biológicas, as proteínas podem ter alterações em sua atividade após os danos causados pela irradiação. A presença ou ausência de oxigênio é outro fator que afeta a inativação. $O$ oxigênio aumenta a taxa de inativação de enzimas como a lisozima e tripsina.

Baucia et al. (2007) estudaram os efeitos da irradiação gama no pericárdio bovino tratado com glutaraldeído e concluíram que a irradiação gama não reduziu os níveis de $\mathrm{Ca}^{2+}$ em implantes subcutâneos em ratos por quatro meses. A irradiação gama promoveu alteração significativa no comportamento mecânico do tecido com redução na sua resistência, quando comparados com o grupo controle, mesmo quando empregadas baixas doses de radiação.

Amostras de pericárdio bovino foram irradiadas com raios-X (10-50 Gy). Após os testes mecânicos foi observado um aumento no módulo de elasticidade inicial, provavelmente devido à reticulações induzidas pela irradiação. A redução do módulo final provavelmente reflete a cisão das cadeias também induzido pela irradiação (MOHAMED; BRADLEY; WINLOVE, 2007).

Bailey e Tromans (1964) examinaram por microscopia eletrônica fibras de colágeno irradiadas em acelerador de elétrons. Não foram observados efeitos quando as amostras foram irradiadas até 10 Mrads (1 kGy), mas acima 
desta dose foi observada uma degradação gradual das bandas das fibrilas do colágeno. Este estudo também indicou que ligações intermoleculares foram produzidas quando as fibras foram irradiadas na presença da água. Em contraste, a irradiação das fibras secas resultou em fragmentação da macromolécula.

Os feixes de elétrons são amplamente utilizados na reticulação de polímeros, sendo descrito também para a reticulação de colágeno reconstituído. Confere maior resistência à digestão enzimática e aumento na temperatura de colapso (JIANG et al., 2006).

A avaliação da reticulação dos polímeros é realizada pela determinação dos parâmetros de intumescimento, por meio de membranas que podem absorver líquidos, e por avaliação das mudanças nas suas propriedades reológicas, como a Tg. (LABANA, 1985).

\subsection{Fibroína de seda (SF)}

A seda é uma proteína fibrilar muito apreciada na indústria têxtil por suas propriedades excepcionais tais como maleabilidade, maciez, brilho, pode ser tingida, é bastante confortável e também devido às suas propriedades mecânicas. Além da aplicação têxtil a seda vem sendo estudada para seu uso em aplicações de interesse biomédico e biotecnológico (FREDDI; PESSINA; TSUKADA, 1999).

A fibroína de seda, uma proteína pura da seda, vem sendo utilizada comercialmente como material para suturas por décadas. Devido à sua biocompatibilidade, permeabilidade ao oxigênio e à água, características de adesão e crescimento celular, baixa trombogenicidade, baixa resposta inflamatória, e a mais importante, a alta elasticidade e flexibilidade, tornam a fibroína um material atrativo para ser estudado em aplicações biomédicas (GOBIN; FROUDE; MATHUR, 2005).

O bicho-da-seda, Bombyx mori, é um produtor abundante de fibroína da seda. Esta proteína é composta por duas cadeias - uma de alto peso molecular, de aproximadamente $325 \mathrm{kDa}$, e a de baixo peso molecular, de 
aproximadamente $25 \mathrm{kDa}$ - ligadas por ponte de dissulfeto. Estas duas estão unidas por uma camada de sericina. A remoção da camada de sericina antes do uso remove a resposta trombogênica e inflamatória da fibroína. A estrutura da fibroína da seda é composta de domínios um cristalino e outro amorfo. $O$ domínio cristalino consiste de repetições de glicina e alanina interconectados com os aminoácidos serina ou tirosina, na proporção de 3:2:1. O domínio amorfo consiste de aminoácidos volumosos assim como o ácido aspártico. Os domínios cristalinos formam uma estrutura secundária de folha- $\beta$ antiparalela das repetições de alanina-glicina (Figura 3). Esta configuração estrutural confere à fibroína suas propriedades mecânicas que incluem alta elasticidade e flexibilidade. A fibroína vem sendo extensivamente investigada e usada em diversas aplicações (KITAGAWA; YABUKI, 2001; ALTMAN et al., 2003).

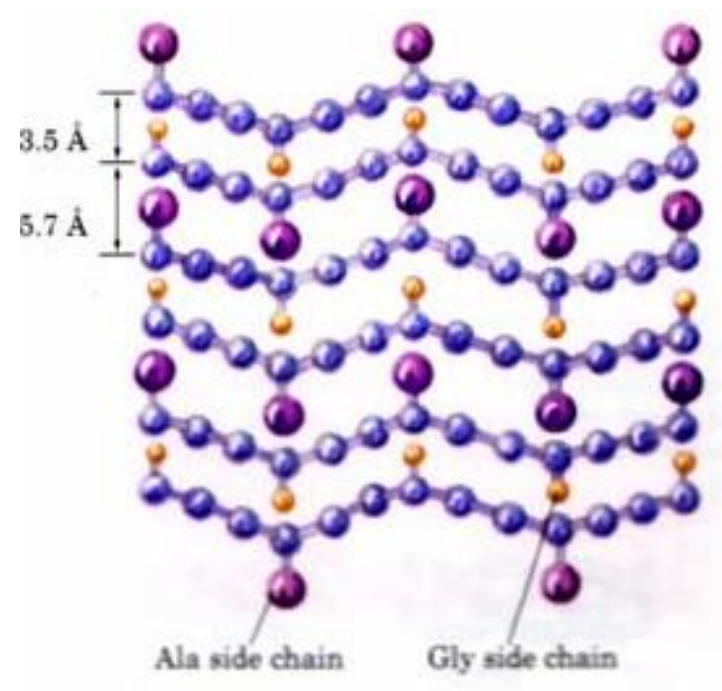

Figura 3. Estrutura secundária de fibroína de seda - folha- $\beta$ antiparalela.

Alguns pesquisadores verificaram a interação da fibroína de seda com fibroblastos (SERVOLI et al., 2005), queratinócitos (GUPTA et al., 2007) e células endoteliais (FUCHS et al., 2006). A habilidade do material implantado aderir e crescer células endoteliais são características desejadas em materiais cardiovasculares, uma vez que o crescimento de uma camada celular na superfície do material pode melhorar suas características, como por exemplo, resistência mecânica (FEUGUIER et al., 2005). 
Em trabalho recente ficou demonstrado que membranas de fibroína de seda densa podem ser esterilizadas por radiação gama e são materiais adequados para aderência e crescimento de células endoteliais. Devido a estas características, a fibroína pode ser utilizada como material na cobertura ou na preparação de implantes cardiovasculares (NOGUEIRA, 2009).

Para a utilização da fibroína nas diversas aplicações de interesse biomédico e biotecnológico faz-se necessária a dissolução de suas fibras após a remoção da sericina e sua posterior regeneração em forma de membranas, géis, pós e filmes, dependendo da aplicação. Para isso vários tipos de solventes podem ser utilizados, e após a diálise obtém-se uma suspensão com as fibras de fibroína livre de sais e outros solventes.

O solvente ideal deve ser capaz de penetrar dentro da fibra e promover a solvatação sem induzir reações adversas, tais como despolimerização ou derivatização. Chen et al., (2001) estudaram o efeito de vários solventes na solvatação da seda, e verificaram que os principais solventes utilizados como soluções aquosas concentradas com sais de lítio ( $\mathrm{LiBr}$, LiSCN); MMNO (Nmethyl morpholine $\mathrm{N}$-oxide), que também foi utilizado com sucesso por Freddi, Pessina e Tsukada (1999); e uma mistura de $\mathrm{CaCl}_{2} / \mathrm{H}_{2} \mathrm{O} / \mathrm{EtOH}$ na proporção molar de 1:8:2.

O solvente ternário $\mathrm{CaCl}_{2}-\mathrm{EtOH}-\mathrm{H}_{2} \mathrm{O}$ na proporção de 1:2:8 molar, além de promover a solvatação desejada, não contém produtos extremamente tóxicos. A alta concentração de sal na formulação tem o papel de aumentar a condutividade e a força iônica do meio, que por sua vez promove o rompimento ou a modificação das ligações de hidrogênio da cadeia peptídica, possibilitando a dissolução dos fios ("salting in"). O etanol favorece a dissolução do sal e promove uma desnaturação mais branda, evitando o colapso interno da proteína (CHEN et al., 2001).

Chen, Li e Yu (1997) demonstraram que a fibroína de seda apresenta a conformação em folha-( quando misturada a soluções de quitosana (PolymerInduced Conformation). 


\subsection{Quitosana (Q)}

A quitina é o segundo polissacarídeo mais abundante na natureza depois da celulose (KUMAR, 2000). É constituinte do exoesqueleto de crustáceos (caranguejo, camarão e lagosta), moluscos, insetos e também está presente na parede celular de alguns fungos. $\mathrm{Na}$ natureza a quitina normalmente está complexada com proteínas em insetos e em crustáceos, e no caso de fungos com polissacarídeos (celulose). A quitina é obtida por desmineralização e desproteinização das carapaças com soluções diluídas de $\mathrm{HCl}$ e $\mathrm{NaOH}$, seguida de descoloração com $\mathrm{KMnO} 4$ e ácido oxálico, por exemplo. A quitina obtida é o biopolímero contendo grupos acetil ( $\mathrm{NHCOCH} 3)$ O principal derivado da quitina é a quitosana (Figura 4), um biopolímero do tipo polissacarídeo obtido por meio de desacetilação alcalina da quitina. A quitosana, por ser um produto natural, de baixo custo, biodegradável e de fonte renovável é de grande importância econômica e ambiental. As carapaças de crustáceos são resíduos abundantes e rejeitados pela indústria pesqueira, que em muitos casos as consideram poluentes. Sua utilização reduz o impacto ambiental causado pelo acúmulo nos locais onde é gerado ou estocado. As propriedades químicas, físicas e mecânicas da quitosana permitem sua aplicação nas áreas biomédica e farmacêutica, tais como: membranas de hemodiálise, peles artificiais, curativos para feridas e membranas para liberação controlada de fármacos, entre outras. Estudos com a quitosana vêm sendo intensificados para aplicações na engenharia de tecidos, durante os últimos 25 anos (GOBIN; FROUDE; MATHUR, 2005; KHOR, 2002).

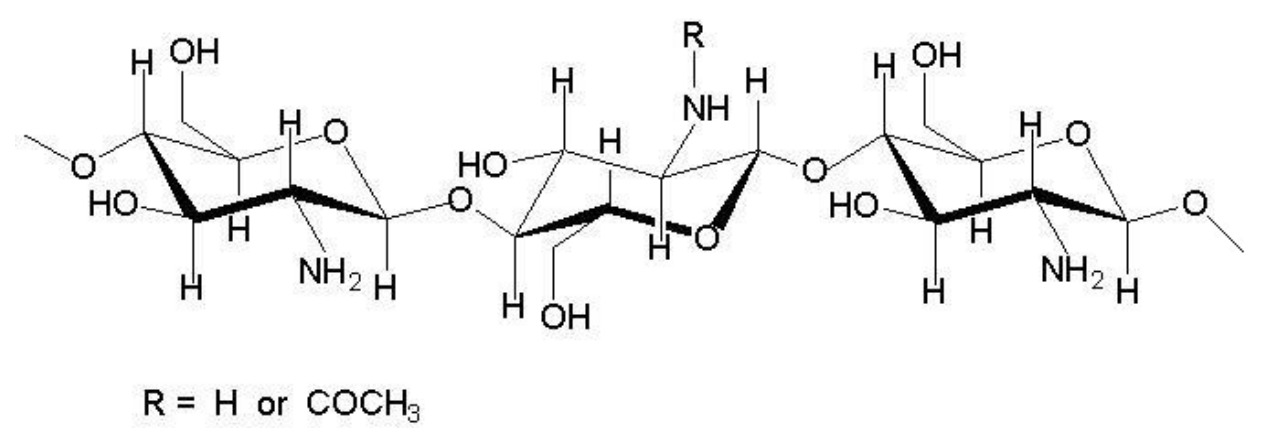

Figura 4. Estrutura química da quitosana. 
A quitosana possui uma estrutura molecular quimicamente similar à celulose, diferenciando-se somente nos grupos funcionais. Na celulose grupos hidroxil $(\mathrm{OH})$ estão dispostos na estrutura geral. No caso da quitosana são os grupos amino $\left(\mathrm{NH}_{2}\right)$. A quitosana é solúvel em meio ácido diluído, formando um polímero catiônico, com a protonação dos grupamentos amino $\left(\mathrm{NH}_{3}{ }^{+}\right)$ (ROBERTS, 1992; MADIHALLY; MATTHEW, 1999). No entanto algumas aplicações farmacêuticas da quitosana em meio ácido se tornam limitadas, já que as enzimas exercem suas atividades em meio neutro. Para isso alguns derivados hidrossolúveis da quitosana podem ser preparados a fim de aumentar significativamente suas aplicações. Alguns exemplos de modificação bastante utilizados são a $\mathrm{N}$-succinilquitosana, $\mathrm{N}$-carboximetilquitosana e Ocarboximetilquitosana (MELLO et al., 2006; SILVA; SANTOS; FERREIRA, 2006).

A $Q$ é composta de unidades de glucosamina e $\mathrm{N}$-acetil-glucosamina unidas por ligações $\beta$-(1-4)-glicosídicas. A quantidade de glucosamina é chamada de grau de desacetilação (GD), ou seja, a porcentagem de grupos amino presentes no biopolímero. Dependendo da fonte e do procedimento de preparação, seu peso molecular pode variar de 300 a $1000 \mathrm{kDa}$, com um GD de 30 a 95\%. (DORNISH; KAPLAN; SKAUGRUD, 2001; VANDEVORD et al., 2002). A quitosana tem três tipos de grupos funcionais reativos, um grupamento amino, um grupo hidroxila primário e um grupo hidroxila secundário, respectivamente, nas posições $C(2), C(3)$, e $C(6)$. Esses grupos permitem a modificação da quitosana, que podem produzir vários materiais de sustentação para a engenharia de tecidos. A natureza química da quitosana proporciona muitas possibilidades de modificações covalentes e iônicas a qual permite ajustes de propriedades mecânicas e biológicas. As propriedades da quitosana como tecido de sustentação, e sua aplicação em osso, pele, cartilagem, fígado, nervo e vaso sanguíneo, demonstram sua utilidade como potencial material para vários tecidos e órgãos artificiais (KIM et al., 2008). 


\section{OBJETIVOS}

\subsection{Objetivo geral}

O presente trabalho teve como objetivo principal desenvolver alguns modelos de biomateriais à base de quitosana e fibroína de seda conjugadas com pericárdio bovino, empregando a liofilização e irradiação como mediadores do processo de obtenção.

\subsection{Objetivos específicos}

- Avaliar os efeitos da irradiação por feixe de elétrons no tecido liofilizado de pericárdio bovino para o desenvolvimento de um biomaterial.

- Determinar o tempo de exposição e a concentração das soluções de quitosana e fibroína de seda para uma máxima absorção desses materiais no tecido de pericárdio bovino.

- Determinar os parâmetros de liofilização das soluções de quitosana e fibroína de seda.

- Modificar o tecido de PB liofilizado utilizando soluções de quitosana, fibroína de seda seguido de sua liofilização e irradiação.

- Avaliar os novos materiais quanto à estrutura secundária, citotoxicidade, biofuncionalidade e calcificação. 


\section{MATERIAL E MÉTODOS}

\subsection{Obtenção do pericárdio bovino}

O pericárdio bovino utilizado neste trabalho foi comprado da empresa HP Biopróteses, especializada em próteses cardíacas e cerebrais. O lote utilizado foi o de $\mathrm{n}^{\circ}$ 264. O PB, coletado em um matadouro, foi limpo para remoção da gordura, lavado com $500 \mathrm{~mL}$ de solução salina ( $\mathrm{NaCl} 0,9 \%)$ e armazenado em glicerol (89\%). Antes do uso, amostras de PB foram lavadas novamente com $500 \mathrm{~mL}$ solução salina $(\mathrm{NaCl} 0,9 \%)$ por três vezes de quinze minutos para remoção do glicerol.

\subsection{Liofilização do pericárdio bovino}

Amostras de PB foram liofilizadas utilizando-se o tratamento térmico annealing (LEIRNER; TATTINI JR.; PITOMBO, 2009) e mantidas em um dessecador sob vácuo para não absorverem umidade até a etapa de sua irradiação. A liofilização foi realizada em um liofilizador da marca Edwards.

\subsection{Irradiação do PB}

O material foi irradiado em um acelerador de elétrons (Figura 5) localizado no IPEN - CNEN (Instituto de Pesquisas Energéticas e Nucleares Comissão Nacional de Energia Nuclear) da marca Dynamitron $\AA$, modelo JOB 188 com energia de $0,5 \mathrm{MeV}$ a $1,5 \mathrm{MeV}$ e corrente de $0,3 \mathrm{~mA}$ a $25 \mathrm{~mA}$. As amostras foram embaladas separadamente em embalagem de polietileno de baixa densidade (PEBD) em uma seladora. As amostras foram irradiadas em diferentes doses e diferentes taxas de dose utilizando-se uma energia de radiação de $0,550 \mathrm{MeV}$. 


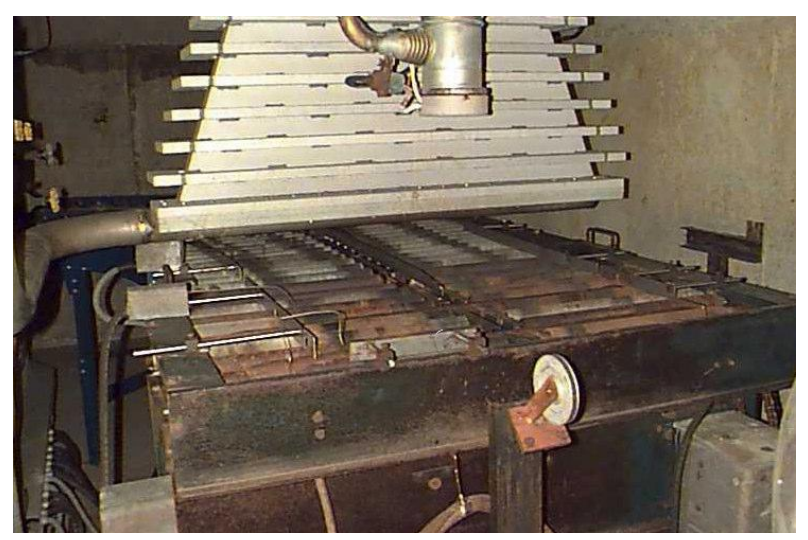

Figura 5. Acelerador de elétrons JOB 188 (IPEN).

Para realizar a irradiação foi necessário conhecer a espessura das amostras. Para isso, a espessura das amostras de PB foram medidas com micrômetro digital da marca Miutoyo. Para cada amostra foi feita uma média de três valores. A espessura da embalagem também foi medida (50 $\mu \mathrm{m}$ ) e foi descontada do valor das amostras. A densidade do material a ser irradiado e do material de embalagem também é fator relevante. Para embalar as amostras utilizou-se envelope plástico de polietileno em baixa densidade (PEBD) que apresenta densidade de 0,91-0,94 $\mathrm{g} / \mathrm{cm}^{3}$. A densidade do PB liofilizado e fresco foi obtida através de ensaio com picnômetro (PB liofilizado densidade $=0,38 \mathrm{~g} / \mathrm{cm}^{3} ;$ PB fresco - densidade $=1,3 \mathrm{~g} / \mathrm{cm}^{3}$ ).

Após tomar conhecimento dos valores acima foram calculados os parâmetros para irradiar as amostras o mais próximo possível dos valores teóricos estipulados. Os valores de dose e taxa de dose foram escolhidos a partir de um trabalho preliminar realizado em nosso grupo de pesquisa (Processo FAPESP: 05/57419-7). Na tabela 1 podem ser observados os valores efetivamente aplicados, a corrente de feixe em $\mathrm{mA}$ e o número de voltas que a amostra passou por baixo da fonte de irradiação. A energia de irradiação utilizada foi igual para todas as amostras (0,550 MeV). A corrente de feixe determinou a taxa de dose. A velocidade da esteira foi de 6,72 metros/minuto. O tempo de exposição foi determinado pelo número de passadas. 
Tabela 1. Doses e taxas efetivas aplicadas no tecido de pericárdio bovino.

\begin{tabular}{cccc}
\hline Doses (kGy) & Taxas (kGy/s) & $\begin{array}{c}\text { Corrente de feixe } \\
\text { (mA) }\end{array}$ & $\mathbf{N}^{\circ}$ de passadas $^{*}$ \\
\hline \multirow{2}{*}{$\mathbf{1 2 , 5}$} & 4,67 & 0,67 & 12 \\
& 9,34 & 1,34 & 6 \\
& 28,03 & 4,02 & 2 \\
25 & 4,67 & 0,67 & 24 \\
& 9,34 & 1,34 & 12 \\
\hline
\end{tabular}

* duas passadas pelo feixe correspondem a uma volta.

Depois de irradiadas as amostras foram mantidas em geladeira até as análises.

\subsection{Calorimetria exploratória diferencial (DSC)}

Análises de DSC foram realizadas para verificar a temperatura de transição vítrea ( $\mathrm{Tg}$ ) e a temperatura de encolhimento das amostras irradiadas. Os dados foram colhidos utilizando-se os equipamentos DSC $822^{\mathrm{e}}$ Mettler Toledo e DSC 4000 Perkin Elmer, respectivamente. As amostras (aproximadamente $5 \mathrm{mg}$ ) foram acondicionadas em cadinhos de alumínio, selados e submetidas a um programa de aumento de temperatura iniciando em $25^{\circ} \mathrm{C}$, aquecimento de $10^{\circ} \mathrm{C} / \mathrm{min}$ até atingir a temperatura de $250^{\circ} \mathrm{C}$, em atmosfera de $\mathrm{N}_{2}$ (fluxo de $50 \mathrm{~mL} / \mathrm{min}$ ). Um cadinho selado vazio foi utilizado como referência. Um padrão de índio foi usado para calibração prévia da temperatura e fluxo de calor. Os dados obtidos foram processados no programa Pyris.

\subsection{Análise termogravimétrica (TGA)}

A perda da massa foi determinada utilizando-se um programa de aquecimento linear (TG convencional). Aproximadamente $5 \mathrm{mg}$ de amostra foram acomodadas em um cadinho aberto de platina. A amostra foi submetida a uma programação controlada de temperatura iniciando o experimento a $25^{\circ} \mathrm{C}$ até atingir $800^{\circ} \mathrm{C}$, com aquecimento de $10^{\circ} \mathrm{C} / \mathrm{min}$, em atmosfera de $\mathrm{O}_{2}$ (fluxo de 
$50 \mathrm{~mL} / \mathrm{min}$ ). O experimento foi realizado em um equipamento TGA-50 Shimadzu. Os dados foram tratados no programa TA60.

\subsection{Espectroscopia Raman}

O espectrômetro Raman modelo FRA106 (da Bruker Optics) acoplado a um NIR (modelo IFS 28/N) possui uma ampla faixa espectral de análise (0$4000 \mathrm{~cm}^{-1}$ ). Todas as amostras foram analisadas via off-line à temperatura ambiente $\left(20^{\circ} \mathrm{C}\right)$ utilizando uma resolução de análise de $4 \mathrm{~cm}^{-1}$, potencia do laser igual a $510 \mathrm{~mW}$ e uma varredura de 512 scans. Para cada amostra analisada foi realizada uma média de três varreduras $(n=3)$. A aquisição de dados e tratamento dos espectros foi desenvolvida através do pacote computacional OPUS, próprio do equipamento. O equipamento foi calibrado utilizando-se um padrão de Nylon.

\subsection{Microscopia eletrônica de varredura (MEV)}

Micrografias das amostras foram captadas através de um equipamento de microscopia eletrônica de varredura com emissão de campo da marca Jeol, modelo JSM 7401-F, utilizando-se aumento de 500 vezes. As amostras foram recobertas com ouro por 5 segundos.

\subsection{Teste de intumescimento}

O intumescimento foi determinado pela relação:

$$
\mathrm{I} \%=\frac{\mathrm{m} f-\mathrm{m} i}{\mathrm{~m} i} \times 100
$$

Onde: I \% é o grau de intumescimento em porcentagem, $\mathrm{m}_{f}$ é a massa final em gramas e $m_{i}$ é a massa inicial em gramas (RODAS, 2004). 
Cada amostra, com tamanho médio de $3 \mathrm{~cm}^{2}$, foi previamente pesada e então colocada em frasco com tampa contendo água ultrapura em excesso (aproximadamente $45 \mathrm{~mL}$ ). A pesagem foi realizada retirando-se o excesso de água em papel absorvente. As amostras foram pesadas até atingir o equilíbrio, ou seja, três pontos consecutivos sem grande variação de peso. Para este estudos foram utilizadas três amostras para cada ponto $(n=3)$.

\subsection{Testes de tração}

O teste de tração foi efetuado em um texturômetro TA-XT2 Texture Analyser-Stable Micro Systems com célula de carga de 245,1662 N e sensibilidade $9,806.10^{-3} \mathrm{~N}$. A velocidade de teste foi de $0,2 \mathrm{~mm} / \mathrm{min}$ de acordo com a norma ASTM D638 para corpos de teste do tipo V. Os corpos de prova (Figura 6) foram submetidos à tração até a ruptura. Para cada amostra foram realizados 50 testes $(n=50)$. Após os testes os dados coletados foram analisados em um programa desenvolvido no MATLAB, que transforma a curva obtida (força $x$ deslocamento) em tensão x deformação e calcula os valores de tensão de ruptura $\left(\sigma_{\text {rup }}\right)$, o coeficiente de correlação da região elástica da curva $\left(R^{2}\right)$ e o módulo de Young $(E)$.

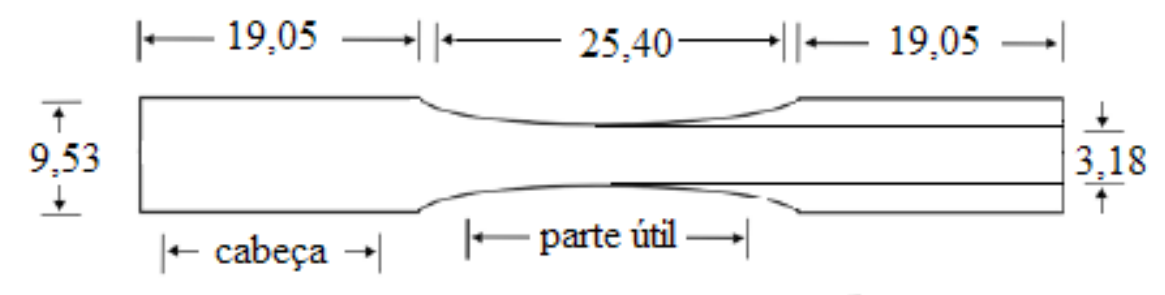

Figura 6. Corpo de prova para teste de tração; medidas em $\mathrm{mm}$.

\subsection{Microscopia eletrônica de transmissão (MET)}

As amostras foram preparadas no Departamento de Biologia Celular e do Desenvolvimento do Instituto de Ciências Biomédicas (ICB) da Universidade 
de São Paulo. Depois de reidratadas as amostras foram fixadas em solução de glutaraldeído $2 \%$ por duas horas. Após a fixação, os fragmentos de $1 \times 1 \mathrm{~mm}$ foram lavados em tampão cacodilato de sódio $0,1 \mathrm{M}$ com pH 7,3 e pós-fixados em tetróxido de ósmio a $1 \%$ em tampão fosfato $0,1 \mathrm{M}$ à temperatura ambiente. Em seguida, os fragmentos foram desidratados em uma série crescente de concentrações de etanol e infiltrados com resina Spürr e óxido de propileno na proporção de 1:1. Para inclusão os tecidos foram deixados em resina pura a temperatura ambiente. Os fragmentos permaneceram em estufa seca a $60^{\circ} \mathrm{C}$ por 48 horas para polimerização da resina e formação dos blocos. Os blocos foram cortados em micrótomo com navalha de vidro em cortes semifinos (400 $\mathrm{nm}$ ), que foram corados com solução aquosa de azul de toluidina a 0,25\% e borato de sódio a 1\%. A partir da observação dos cortes semifinos ao microscópio de luz, foram definidos os melhores campos para a realização dos cortes ultrafinos. Os cortes ulfrafinos, com cerca de $70 \mathrm{~nm}$ de espessura, foram identificados por sua cor prateada devido ao índice de refração quando flutuam na água da cuba do micrótomo. Os cortes selecionados foram depositados em tela de cobre sobre a qual foi realizada a contrastação com solução de acetato de uranila 1\%, seguida de contrastação com citrato de chumbo. As observações e registro fotográfico foram realizados no microscópio eletrônico de transmissão JEOL JEM - 2100 a uma voltagem de 80 kV (IPEN/USP), utilizando-se um aumento de 50.000 vezes.

\subsection{Quitosana (Q)}

A quitosana utilizada neste trabalho é proveniente do laboratório Farma Service Bioextract. Esta quitosana possui um grau de desacetilação (GD) de $80 \%$ e uma massa molar de aproximadamente $600 \mathrm{kDa}$.

\subsubsection{Preparo da solução de quitosana a 1 e $2 \%$}

A uma solução aquosa de ácido acético $(100 \mathrm{~mL}, 1 \% \mathrm{v} / \mathrm{v})$ foi adicionado $1 \mathrm{~g}$ de quitosana (pó) sob agitação constante. Para total solubilização do pó de 
quitosana esta mistura foi deixada sob agitação constante por 24 horas em temperatura ambiente.

\subsubsection{Preparo da N-succinil-quitosana a $2 \%$}

Sob agitação intensa, adicionou-se a $7,85 \mathrm{~g}$ de quitosana $80 \%$ desacetilada 125,6 de água ultrapura. Após a obtenção de um aspecto homogêneo acrescentou-se $20,9 \mathrm{~mL}$ de ácido acético sob agitação até a solução ficar translúcida e viscosa. Ainda sob agitação foi adicionado 510,25 $\mathrm{mL}$ de etanol e em seguida o anidrido succínico $(11,8 \mathrm{~g})$. O meio reacional foi mantido sob agitação por 3 horas e depois em repouso por mais 10 horas. Após o repouso o $\mathrm{pH}$ foi ajustado entre 6,0 - 6,5 utilizando-se solução aquosa de $\mathrm{NaOH} 50 \%$. O produto foi filtrado e quando estava semi-úmido para seco foi ressolubilizado em $500 \mathrm{~mL}$ de água ultrapura e o $\mathrm{pH}$ foi ajustado para 7,0 antes de chegar ao volume final, sob agitação constante (MELLO et al., 2006).

\subsection{Fibroína de seda}

Os fios de seda provenientes do bicho-da-seda Bombyx mori, foram fornecidos pela indústria brasileira Bratac.

\subsubsection{Remoção da sericina}

$50 \mathrm{~g}$ de seda foram lavadas em $600 \mathrm{~mL}$ de solução aquosa de carbonato de sódio $\left(\mathrm{Na}_{2} \mathrm{CO}_{3}\right)$ 0,5\% (massa), durante 30 minutos em banho termostático entre $85-90^{\circ} \mathrm{C}$. Este procedimento foi repetido por três vezes e ao final os fios foram lavados abundantemente em água destilada por 10 vezes. Os fios foram então espremidos para retirar o excesso de água e foram secos à temperatura ambiente por 24-48 h. Após a secagem, a perda da massa calculada foi de $20 \%$.

\subsubsection{Preparação da suspensão de fibroína a $2 \%$}

$5 \mathrm{~g}$ de fibroína foram adicionados a $100 \mathrm{ml}$ de solução ternária $\mathrm{CaCl}_{2^{-}}$ EtOH- $\mathrm{H}_{2} \mathrm{O}$ na proporção de 1:2:8 molar (relação molar de cada reagente). A fibroína foi cortada em pedaços de $1 \mathrm{~cm}$ de comprimento a fim de facilitar sua dissolução. A suspensão obtida foi mantida entre $85-90^{\circ} \mathrm{C}$ em banho 
termostático sob agitação mecânica até completa dissolução da fibroína (CHEN et al., 2001). A suspensão obtida é translúcida, viscosa, e não apresenta fibrilas visíveis a olho nu. A solução de fibroína resultante foi dialisada por três dias em banho termostático a $8^{\circ} \mathrm{C}$. A diálise foi realizada utilizando-se tubo de diálise Sigma-aldrich® com membrana de celulose com cut-off de $12.400 \mathrm{Da}$, em água ultrapura trocada a cada 24 horas (HU et al., 2008; NOGUEIRA, 2009).

Abaixo está representada de forma sucinta a preparação da fibroína de seda (Figura 7).

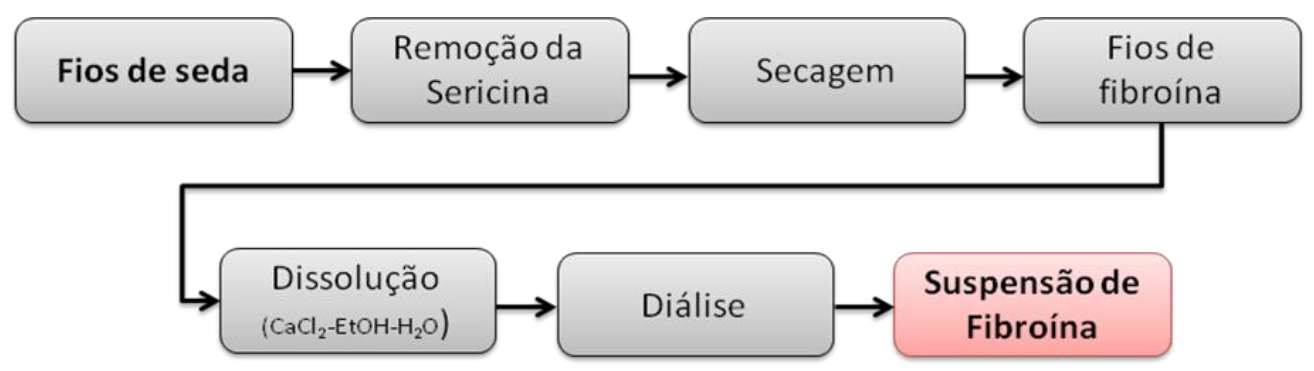

Figura 7. Etapas envolvidas na preparação da suspensão de SF.

\subsection{Congelamento e liofilização para modificações do PB com fibroína de seda e quitosana}

Os processos de liofilização foram conduzidos em um liofilizador da marca FTS Systems, modelo TDS-00209-A, controlado por microprocessador (DuraStop, Dura-Dry-MP). Amostras de tamanho adequado foram acomodadas em placas de Petri e submetidas ao congelamento. Para a realização do tratamento térmico (annealing) as amostras de pericárdio bovino foram primeiramente congeladas até $-40^{\circ} \mathrm{C}$, permanecendo nesta temperatura por 2 horas, depois foram aquecidas até temperatura de $-20^{\circ} \mathrm{C}$, mantidas nesta temperatura por 1 hora e finalmente congeladas até a temperatura de $-40^{\circ} \mathrm{C}$ por mais 2 horas antes de iniciar o processo de liofilização. A secagem primária foi conduzida com temperatura de placa de $-5^{\circ} \mathrm{C}$ e pressão na câmara de 160 mTorr. A secagem secundária foi conduzida com temperatura de placa de $25^{\circ} \mathrm{C}$ e a pressão na câmara de 21,33 Pa Após a incorporação das soluções, as 
membranas de PB modificadas foram novamente liofilizadas obedecendo aos parâmetros pré-determinados a partir dos dados obtidos pela microscopia óptica acoplada a um modulo de liofilização. As amostras foram congeladas até $-35^{\circ} \mathrm{C}$ permanecendo nesta temperatura por $3 \mathrm{~h}$, a secagem primária foi conduzida com temperatura de placa de $-15^{\circ} \mathrm{C}$ para as amostras com quitosana e $-30^{\circ} \mathrm{C}$ para as amostras com fibroína e misturas. A pressão na câmara foi de 21,33 $\mathrm{Pa}$. A secagem secundária foi conduzida com temperatura de placa de $25^{\circ} \mathrm{C}$ e a pressão na câmara de 21,33 Pa (BORGOGNONI et al., 2009; LEIRNER; TATTINI JR.; PITOMBO, 2009).

\subsection{Determinação do intumescimento com soluções de fibroína de seda e quitosana}

Amostras de PB liofilizadas com aproximadamente $4 \mathrm{~cm}^{2}$ de tamanho, foram colocadas em excesso (50 mL) das soluções de quitosana (1 e $2 \%$ ), Nsuccinil-quitosana (1\%), fibroína de seda $(2 \%)$ e solução híbrida das duas (ambas a $2 \%$, na proporção de 1:1). O teste foi realizado em triplicata para cada solução e após a pesagem de três pontos consecutivos o teste foi terminado. $O$ intumescimento foi determinado pela relação:

$$
\mathrm{I} \%=\frac{\mathrm{m} f-\mathrm{m} i}{\mathrm{~m} i} \times 100
$$

Onde: $1 \%$ é o grau de intumescimento em porcentagem, $\mathrm{m}_{f}$ é a massa final em gramas e $m_{i}$ é a massa inicial em gramas (RODAS, 2004).

\subsection{Microscopia ótica acoplada à liofilização}

A temperatura de colapso das soluções foi determinada através de um microscópio acoplado a um módulo de liofilização, Lyostat 2, modelo FDCS 196, Linkam Instruments, Surrey, UK, equipado com sistema de congelamento por nitrogênio líquido (LNP94/2) e controlador de temperatura programável (TMS94, Linkam). A pressão utilizada durante as análises foi de 100 mTorr 
através de uma bomba de vácuo (Edwards E2M1.5, Linkam) e monitorada através de uma válvula Pirani. As amostras foram colocadas em uma placa de quartzo de $16 \mathrm{~mm}$, coberta também por quartzo (Linkam) para minimizar gradientes térmicos. A observação direta do congelamento e liofilização foi realizada utilizando-se um microscópio de luz polarizada Nikon, modelo Elipse E600 (Nikon, Japão).

\subsection{Modificação com quitosana, fibroína de seda e suas misturas}

Modificações com fibroína de seda: Pedaços $(6 \times 11 \mathrm{~cm})$ de PB liofilizados foram imersas em solução de SF $2 \%$ (na proporção de $1 \mathrm{ml} \times \mathrm{cm}^{2}$ ) em temperatura ambiente por 12 horas. Após, o excesso da solução foi retirado em papel absorvente e as amostras foram novamente liofilizadas. Metade das amostras liofilizadas foram submetidas à irradiação (dose 25 kGy, taxa de dose 4,67 kGy/s, sob vácuo). Precedendo as análises as amostras foram imersas em etanol 70\% por 20 minutos (LI; TAO; NISHIYAMA, 2003) e depois lavadas em solução fisiológica.

Modificações com quitosana: Pedaços $(6 \times 11 \mathrm{~cm})$ de PB liofilizados foram imersas em solucao de quitosana $2 \%$ em solução aquosa de ácido acético $1 \%$ (na proprocao de $1 \mathrm{ml} \times \mathrm{cm}^{2}$ ) em temperatura ambiente por 12 horas. Após, o excesso da solução foi retirado em papel absorvente e as amostras foram novamente liofilizadas. Metade das amostras liofilizadas foram submetidas a irradiação (dose 25 kGy, taxa de dose 4,67 kGy/s, sob vácuo).

Modificações com solução híbrida de Q e SF: Pedaços $(6 \times 11 \mathrm{~cm})$ de PB liofilizados foram imersos em solução de SF $2 \%$ misturada com solução de $Q$ $2 \%$ em diferentes proporções $\left(1: 3,1: 1\right.$ e $3: 1$ ) (na proporcao de $1 \mathrm{ml} \times \mathrm{cm}^{2}$ ) em temperatura ambiente por 24 horas. Após, o excesso da solução foi retirado em papel absorvente e as amostras foram novamente liofilizadas. Metade das amostras liofilizadas foram submetidas à irradiação (dose 25 kGy, taxa de dose 4,67 kGy/s, sob vácuo). 


\subsection{Teste de citotoxicidade}

O teste de citotoxicidade foi realizado em colaboração no Instituto de Pesquisas Energéticas e Nucleares (IPEN), São Paulo.

Para a avaliação da citotoxicidade foi seguida a norma ISO - 109935:1992. O método empregado para avaliação da viabilidade celular foi o CellTiter96 ${ }^{\circledR}$ AQueous Non - Radioactive Cell Proliferation Assay (Promega Corporation). O teste CellTiter96 ${ }^{\circledR} A Q_{\text {ueous }}$ é um método colorimétrico para determinação do número de células viáveis em testes proliferativos ou quimiosensitivos, preparado com soluções de um composto tetrazólico (3(dimetiltiazol-2-il)-5-(3-carboximetoxifenil)-2-(4-sulfofenil)-2H-tetrazolium, sal inerte; MTS) e um reagente acoplador de elétrons (metassulfato de fenazida; PMS) (CORY et al., 1991). O MTS é biorreduzido pelas células a produto formazan que é solúvel no meio de cultura tecidual. A absorbância do formazan a $490 \mathrm{~nm}$ pode ser medida diretamente de placas de 96 poços sem adição de outros processos. A conversão do MTS em formazan solúvel aquoso é executada pela enzima desidrogenase encontrada em células metabolicamente ativas. A quantidade do produto formazan formado medida pela absorbância a $490 \mathrm{~nm}$ é diretamente proporcional ao número de células viáveis em cultura.

Preparação dos extratos das amostras: os pericárdios bovino tratados foram cortados no tamanho de $2 \times 2 \mathrm{~cm}$. Todas as amostras foram esterilizadas pela exposição à lâmpada UV do fluxo laminar, por 30 minutos cada lado, com o motor do fluxo ligado. Os extratos foram preparados com solução de $\mathrm{NaCl}$ $0,9 \%$ por 48 horas a $37^{\circ} \mathrm{C}$, no banho-maria tipo Dubnoff, com agitação na velocidade 5. A razão entre a área de superfície das amostras e o liquido extrator foi de $1 \mathrm{~cm}^{2} / \mathrm{mL}$. As diluições foram realizadas com meio RPMI 1640 (Gibco - 23400-021).

Controle negativo: polietileno de baixa densidade (PEBD) em grânulos, esterilizados por calor úmido. O extrato foi preparado na condição de $0,2 \mathrm{~g} / \mathrm{mL}$ de meio RPMI 1640, as amostras foram colocadas na incubadora de $\mathrm{CO}_{2}$ a 
$37^{\circ} \mathrm{C}$, por 48 horas, juntamente com as amostras de pericárdios bovino tratados.

Controle positivo: Solução de fenol 0,3\% em meio RPMI 1640.

Diluições dos extratos: 100; 50; 25; 12,5; e 6,25\% em meio RPMI 1640.

Em uma placa de cultura de 96 poços foram colocados $50 \mu \mathrm{L}$ de uma suspensão de células $\mathrm{CHO}$ células de ovário de Hamster Chinês (CHO-K1) da (American Type Culture Collection - ATCC, Manassas, USA) equivalente a concentração de 3000 células por poço, sobre $50 \mu \mathrm{L}$ do extrato em suas diluições em quadruplicata. A placa foi colocada na incubadora úmida com $5 \%$ de $\mathrm{CO}_{2}$ por 72 horas a $37^{\circ} \mathrm{C}$. A viabilidade celular foi determinada pela adição de $20 \mu \mathrm{L}$ de solução de MTS/PMS (20:1) e incubado por mais 2 horas. A placa foi levada a uma leitora de microplacas Molecular Devices - SPECTRA MAX 190 (espectrofotômetro para placas de 96 poços) com filtro de $490 \mathrm{~nm}$. Todos os testes foram realizados com um controle positivo e negativo. A viabilidade celular foi determinada pela relação:

$$
V C(\%)=\left(\frac{\text { DOamostra }}{\text { DOcontrole }}\right) \times 100
$$

Onde: $V C=$ viabilidade celular (\%); DOamostra = densidade óptica da amostra; DOcontrole $=$ densidade óptica do controle.

O Índice de Citotoxicidade - $I C_{50(\%)}$ é a concentração do extrato da amostra que mata $50 \%$ da população de células. Estes dados foram determinados graficamente.

\subsection{Teste de biofuncionalidade}

O teste de biofuncionalidade foi realizado em colaboração no Instituto de Pesquisas Energéticas e Nucleares (IPEN), São Paulo. As células endoteliais utilizadas para avaliação da biofuncionalidade dos materiais são de linhagem estabelecida e adquirida de repositório internacional. As células utilizadas 
foram da linhagem CRL1730 da ATCC provenientes do cordão umbilical humano (HUVEC).

Manutenção das células endoteliais em cultura: As células foram cultivadas em meio Ham's F12K com 2 mM de L-glutamina, ajustado com bicarbonato de sódio para concentração de 1,5 g/L, suplementado com 0,1 $\mathrm{mg} / \mathrm{mL}$ de heparina, 0,05 mg/mL ECGS (endothelial cell growth supplement suplemento de crescimento celular endotelial) (Sigma) e 10\% de soro fetal bovino. Temperatura de incubação foi de $37^{\circ} \mathrm{C}$ com $5 \%$ de $\mathrm{CO}_{2}$. Quando as células ocupavam aproximadamente $80 \%$ da área de cultivo no frasco de cultura foram descoladas pela ação enzimática de solução de tripsina 0,05\%/EDTA 0,02\% e amplificadas na proporção de 1:5.

Cultivo das células endoteliais sobre o pericárdio bovino: As membranas de PB foram acomodadas em uma placa de cultura de 6 poços e sobre elas, foi colocado um anel de aço inoxidável de $16 \mathrm{~mm}$ de diâmetro interno, para delimitação da área de cultivo. As membranas foram deixadas com meio de cultura F12 na incubadora a $37^{\circ} \mathrm{C}$ por uma noite, para ambientação. Uma membrana de Dacron® foi utilizada como referência para este teste (Figura 8).

As células endoteliais na $13^{\underline{a}}$ passagem, quando atingiram a confluência, foram retiradas do frasco de cultura por ação da solução tripsina/EDTA e semeadas 15000 células na área interna de cada anel acomodado sobre as membranas. Após 24 horas os anéis foram retirados e realizou-se a primeira troca do meio de cultura. As membranas com as células foram mantidas na incubadora por 23 dias com troca de meio de cultura de 3 em 3 dias. Após o tempo de incubação, as membranas foram fixadas em metanol e submetidas à reação com anticorpo monoclonal anti-fator VIII humano da Biogenex (marcador específico das células endoteliais humanas cultivadas), a concentração ideal de anticorpo primário para esta reação que foi de 1:10, o qual foi revelado com um anticorpo secundário marcado com fluoresceína, para identificação da atividade funcional das células endoteliais. Para complementação, os núcleos foram corados com solução de brometo de etídio. 
As amostras foram então analisadas no microscópio confocal LSM 510 META ZEISS, nos comprimento de onda de 488 e 514 nm.

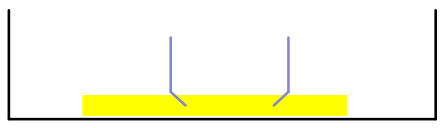

Acomodação das

membranas com anel de aço

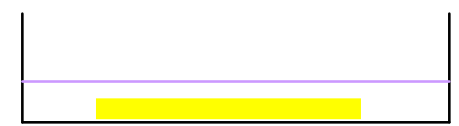

Retirar o anel e realizar a primeira troca do meio de cultura até o final do tempo do experimento
Incubar a $37^{\circ} \mathrm{C}$ por $24 \mathrm{~h}$ com meio de cultura
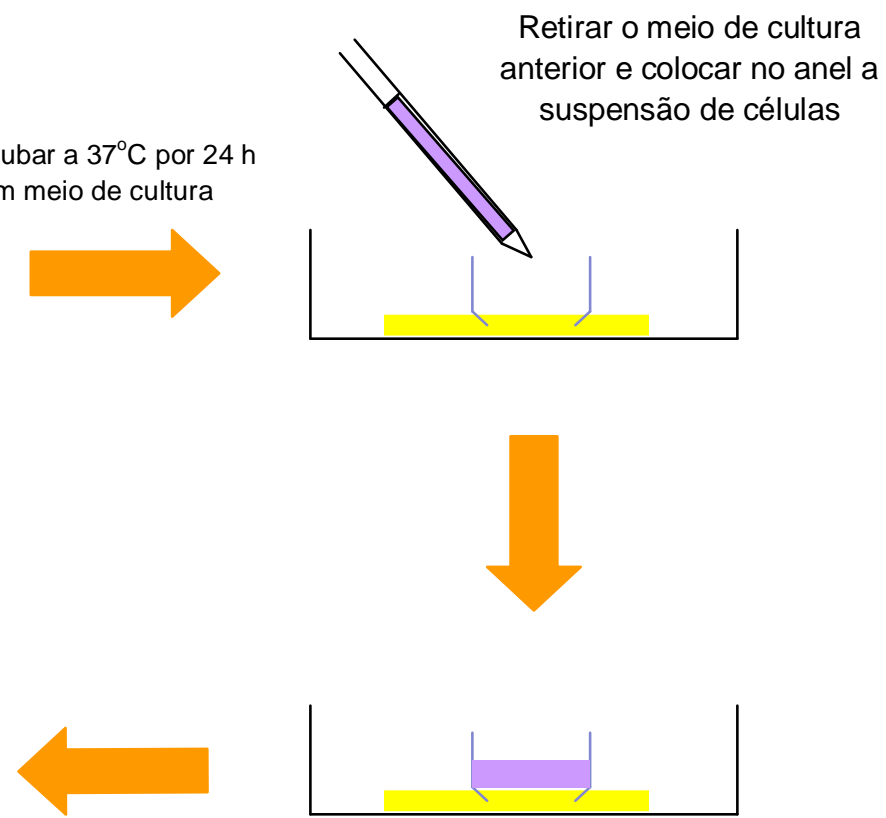

Incubar a $37^{\circ} \mathrm{C}$ por $24 \mathrm{~h}$

Figura 8. Esquema da preparação de amostras para adesão de células endoteliais.

\subsection{Teste de calcificação}

O teste de calcificação in vitro foi realizado deixando as amostras em contato com fluído corpóreo simulado (simulated body fluid - SBF) utilizando-se a metodologia desenvolvida por Kokubo e Takadama (2006). Para realizar o teste foram preparadas soluções de $1 \times$ SBF e 1,5 $\times$ SBF, que apresentam aproximadamente uma vez e uma vez e meia a concentração iônica plasmática, respectivamente (Tabela 2). A solução 1,5 × SBF foi utilizada para acelerar a calcificação in vitro, pois apresenta concentração iônica 50\% maior do que a SBF convencional. 
Tabela 2. Composição do SBF 1 × e SBF 1,5 ×.

\begin{tabular}{c|cc}
\hline Reagente & Quantidade para SBF 1 $\times$ & Quantidade para SBF 1,5 × \\
\hline $\mathrm{NaCl}$ & $8,035 \mathrm{~g}$ & $12,0525 \mathrm{~g}$ \\
$\mathrm{NaHCO}_{3}$ & $0,355 \mathrm{~g}$ & $0,5325 \mathrm{~g}$ \\
$\mathrm{KCl}$ & $0,225 \mathrm{~g}$ & $0,3375 \mathrm{~g}$ \\
$\mathrm{~K}_{2} \mathrm{HPO}_{4}$ anidro & $0,176 \mathrm{~g}$ & $0,264 \mathrm{~g}$ \\
$\mathrm{MgCl}_{2} \cdot 6 \mathrm{H}_{2} \mathrm{O}$ & $0,311 \mathrm{~g}$ & $0,466 \mathrm{~g}$ \\
$\mathrm{HCl}_{1} 1 \mathrm{M}$ & $39 \mathrm{~mL}$ & $39 \mathrm{~mL}$ \\
$\mathrm{CaCl}_{2} \cdot 2 \mathrm{H}_{2} \mathrm{O}$ & $0,386 \mathrm{~g}$ & $0,579 \mathrm{~g}$ \\
$\mathrm{Na}_{2} \mathrm{SO}_{4}$ & 0,072 & $0,108 \mathrm{~g}$ \\
$\mathrm{Tris}$ & $6,118 \mathrm{~g}$ & $6,118 \mathrm{~g}$ \\
$\mathrm{HCl}_{1 \mathrm{M}}$ & $0-5 \mathrm{~mL}$ & $0-5 \mathrm{~mL}$ \\
\hline
\end{tabular}

O preparo destas soluções devem ser preparadas seguindo exatamente as recomendações de preparo sugeridas pelo autor, seguindo a quantidade e a ordem dos reagentes colocados na solução, bem como a temperatura e $\mathrm{pH}$ ao longo do preparo (KOKUBO; TAKADAMA, 2006).

Antes das análises as amostras liofilizadas de PB modificadas com $\mathrm{F}$ e $Q$ e suas misturas $(1: 1,1: 3$ e $3: 1)$ receberam tratamento para evitar a solubilização durante os ensaios. As amostras tratadas com quitosana foram imersas em solução de hidróxido de sódio $1 \mathrm{M}(\mathrm{NaOH})$ durante uma hora. As amostras tratadas com fibroína foram submersas por $1 \mathrm{~h}$ em solução de etanol $70 \%$. Finalmente, as amostras tratadas com as misturas de quitosana e fibroína, foram imersas em solução de hidróxido de sódio $1 \mathrm{M}(\mathrm{NaOH})$ e etanol 
70\%, na proporção de 50:50 (v/v), por uma hora (ALTMAN; GUPTA; RÍOS., 2010).

Amostras de PB de $4 \mathrm{~cm}^{2}$ foram embebidas em $40 \mathrm{~mL}$ das soluções de $\mathrm{SBF}$ a $36,5^{\circ} \mathrm{C}$. A temperatura foi controlada por um banho termostático, sob agitação, durante 7 dias. A solução SBF era trocado a cada 48 horas $(1 \times, 1,5 \times \mathrm{e}$ $1,5 \times \mathrm{SBF}$ ) e o pH da solução foi medida para verificar se as soluções estavam contaminadas. Após sete dias em solução SBF, as amostras foram cuidadosamente lavadas com água deionizada para remover o excesso de sais na superfície e em seguida liofilizadas. A presença de fosfato de cálcio depositado foi observada por MEV e comprovada por EDS (energia dispersiva de raios- $x$ ). Duplicatas de cada amostra foram testadas. 


\section{RESULTADOS E DISCUSSÃO}

\subsection{Efeitos da irradiação por feixe de elétrons no PB liofilizado}

Para uma investigação inicial, a fim de descobrir quais os efeitos da irradiação por feixe de elétrons sobre o tecido de pericárdio bovino, amostras frescas e liofilizadas de PB não tratado foram irradiadas. Os resultados estão discutidos a seguir.

\subsubsection{Determinação da temperatura de transição vítrea $(\mathrm{Tg})$}

Após a irradiação, as amostras foram analisadas por Calorimetria Exploratória Diferencial (DSC). O DSC permite detectar a diferença entre as transições térmicas entre a amostra e sua referência. Através das análises de DSC é possível determinarmos a temperatura de transição vítrea $(\mathrm{Tg})$, temperatura de fusão, temperatura de cristalização, temperatura de encolhimento entre outras.

Primeiramente as amostras foram analisadas em um equipamento de DSC (DSC-60, FC-60A, Shimadzu) que não foi sensível o suficiente para detectar a temperatura de transição vítrea das amostras irradiadas de PB. Isto ocorreu, pois o equipamento apresentava somente dois termopares e, no caso de tecidos biológicos, a $\mathrm{Tg}$ não se apresenta tão expressiva. Portanto as irradiações das amostras de pericárdio bovino tiveram que ser repetidas porque as análises realizadas anteriormente não apresentaram reprodutibilidade. Entretanto, para a análise das amostras frescas o estudo para verificar a $\mathrm{Tg}$ destas amostras requer um equipamento onde temperaturas negativas são atingidas $\left(-100^{\circ} \mathrm{C}\right)$ e não houve disponibilidade de outro equipamento para a análise destas amostras.

Após realizar novamente as análises em um equipamento com maior sensibilidade (DSC $822^{\mathrm{e}}$ Mettler Toledo - 56 termopares) as curvas das amostras liofilizadas de pericárdio bovino não irradiado mostraram que a transição vítrea $(\mathrm{Tg})$ parece estar próxima de $59^{\circ} \mathrm{C}$ (Figura 9). 


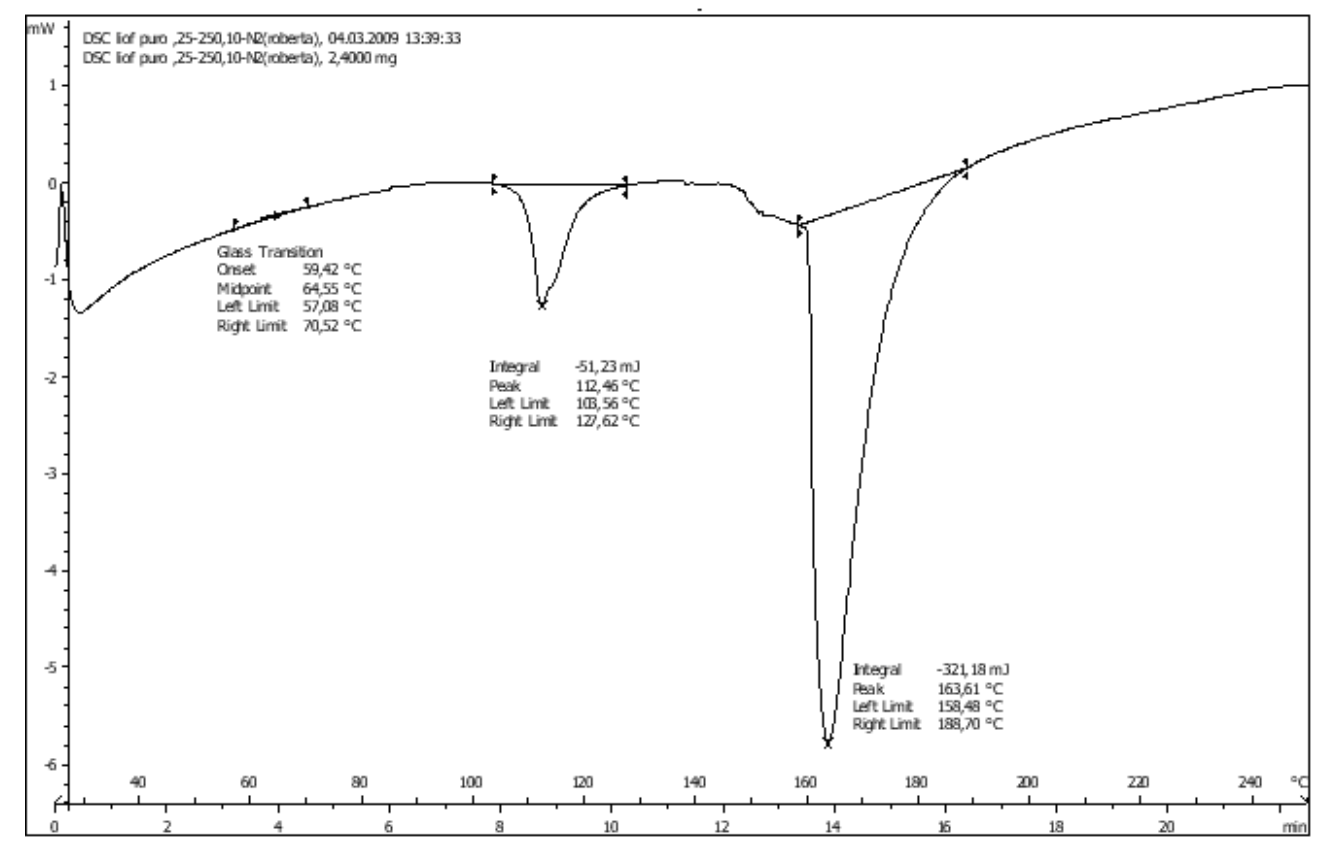

Figura 9. Análise de DSC do tecido de pericárdio bovino liofilizado e não irradiado.

Cada amostra foi analisada por pelo menos três vezes e obteve-se uma média dos valores de Tg (Tabela 3). Como pode ser observado na Tabela 3 , apenas duas diferentes taxas de dose utilizadas (4,67 e 9,34 kGy/s), ambas na dose de 25 kGy, parecem realizar alterações no tecido provocando o aumento da transição vítrea $(\mathrm{Tg})$ do tecido em quase $15^{\circ} \mathrm{C}(20 \%)$. Este fenômeno sugere que após a irradiação das amostras houve uma diminuição da fase amorfa e conseqüentemente um aumento da estrutura cristalina no tecido de pericárdio bovino. Esse resultado indica uma possível reação de ligação cruzada (crosslink) entre as fibras de colágeno deixando a estrutura mais rígida e diminuindo a mobilidade da fase amorfa.

Tabela 3. Média dos valores de Tg obtidos por DSC.

\begin{tabular}{c|cc}
\hline Taxa de dose (kGy/s) & Dose (kGy) & Média da Tg $\left({ }^{\circ} \mathbf{C}\right)$ \\
\hline 4,67 & & 51,61 \\
9,34 & 12,5 & 48,47 \\
28,03 & & 50,37 \\
4,67 & & 74,04 \\
9,34 & 25 & 76,17 \\
28,03 & & 52,9 \\
\hline
\end{tabular}


De acordo com os resultados obtidos por DSC (Tabela 3) foi possível observar que para todas as amostras irradiadas na menor dose (12,5 kGy) e a amostra irradiada na maior dose de 25 kGy (com a taxa de dose máxima de 28,03 kGy/s), houve uma diminuição da temperatura de transição vítrea, em maior ou menor proporção. Isto indica que houve um possível aumento da fase amorfa na estrutura do tecido, sugerindo que pode ter ocorrido como resultado final da irradiação, a quebra das cadeias de colágeno.

A Tg é caracterizada na curva de DSC por uma mudança na linha base. A Tg é considerada uma transição de segunda ordem e é caracterizada por uma interrupção na relação entre temperatura e capacidade calorífica. Ocorre em polímeros amorfos ou na fase amorfa de polímeros semicristalinos. A mobilidade dos segmentos de cadeia é maior acima da $\mathrm{Tg}$, e abaixo desta temperatura comporta-se como um sólido (EHRENSTEIN; RIEDEL; TRAWIEL, 2004) Entretanto, a técnica de DSC quando aplicada para a determinação da Tg, que é bastante utilizada para a caracterização de polímeros, é uma técnica que deve ser aplicada com cautela em tecidos biológicos. Isto se deve ao fato de que ao observarmos as curvas, estes declives não são tão expressivos como observados em polímeros sintéticos, podendo levar a interpretações errôneas das curvas em relação à Tg. Além disso, deve-se utilizar um equipamento que possua mais termopares, para que a Tg possa ser detectada. Neste trabalho, equipamentos com somente dois termopares (DSC 50 Shimadzu e DSC-60, FC-60A Shimadzu) não foi possível a detecção do sinal. Já para estudar outros fenômenos, como por exemplo, a temperatura de encolhimento, a técnica já se mostra mais sensível (TATTINI JR et al., 2007).

\subsubsection{Caracterização das amostras irradiadas por espectroscopia vibracional Raman}

De acordo com as análises de espectroscopia Raman, foi possível observar que esta técnica apresenta boa sensibilidade para avaliar a influência de diferentes doses e também das taxas de dose sobre a estrutura secundária 
do tecido de pericárdio bovino (Figuras 6 e 7). Nos espectros obtidos por FTRaman, os principais picos característicos para a estrutura do colágeno tipo I, principal componente do tecido de PB, são as regiões da Amida III (aproximadamente em $1242 \mathrm{~cm}^{-1}$ ), da $\delta_{-\mathrm{NH}}$ (aproximadamente em $1450 \mathrm{~cm}^{-1}$ ) e da Amida I (aproximadamente em $1665 \mathrm{~cm}^{-1}$ ) (KUBISZ; POLOMSKA, 2007).

Com a espectroscopia Raman foi possível observar que após a irradiação, os picos característicos, responsáveis pela estrutura secundária do colágeno (Amida I e Amida III), foram mantidos (Figuras 10a e 11a). Porém, observou-se que estes apresentavam diferentes intensidades. O tratamento espectral da segunda derivada (método Savitzky-Golay), método que faz um ajuste na linha base e alisamento de 21 pontos (smoothing), foi realizado para confirmar a variação espectral, e para estabelecer alguma alteração significativa no tecido de pericárdio bovino (Figuras 10b e 11b).

Após estas análises foi possível verificar que a irradiação parece não modificar consideravelmente a conformação da estrutura do PB. Portanto, é possível sugerir que não há uma degradação completa das triplas-hélices de colágeno, presentes no tecido, no caso das amostras irradiadas cujas Tg's parecem ter sido alteradas para temperaturas menores. 


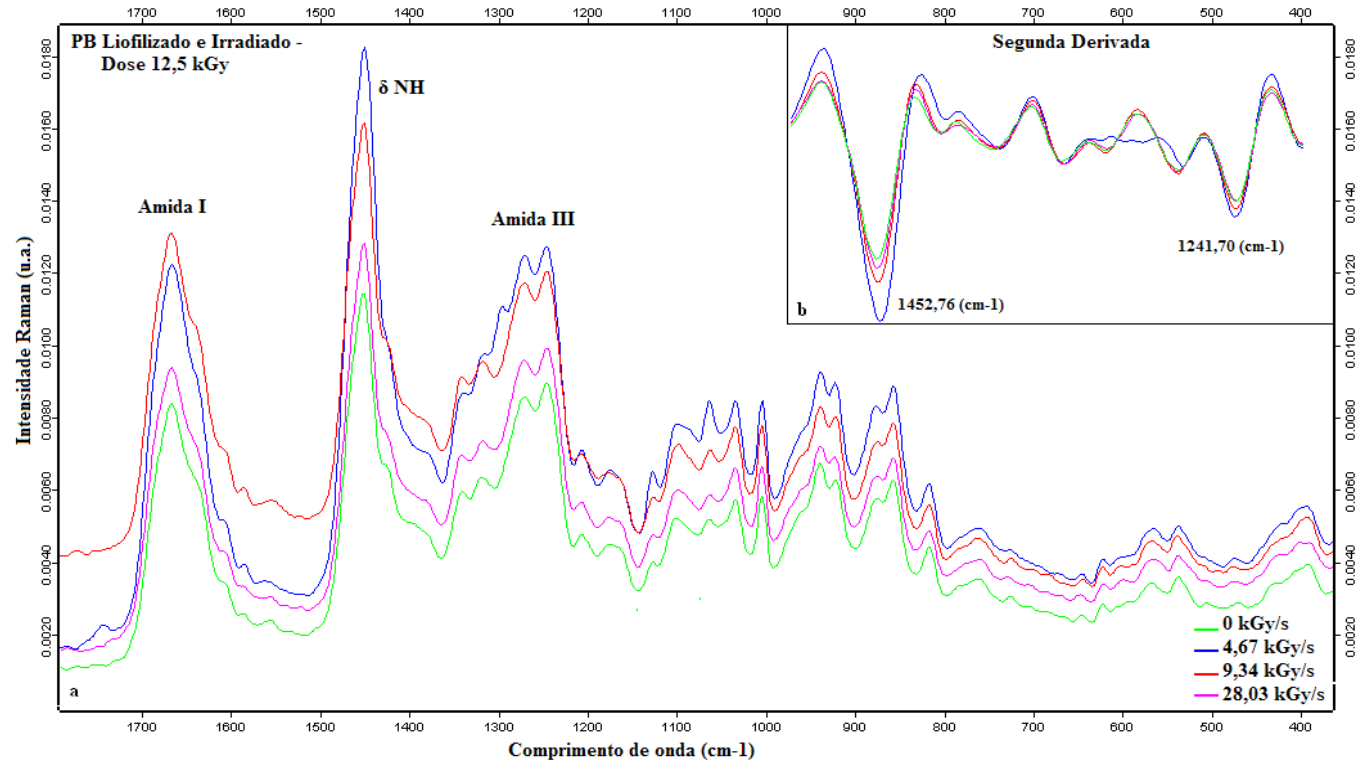

Figura 10. Espectro Raman das principais estruturas do PB. Amostras de pericárdio bovino liofilizado e irradiado na dose de 12,5 kGy e em diferentes taxas de dose.

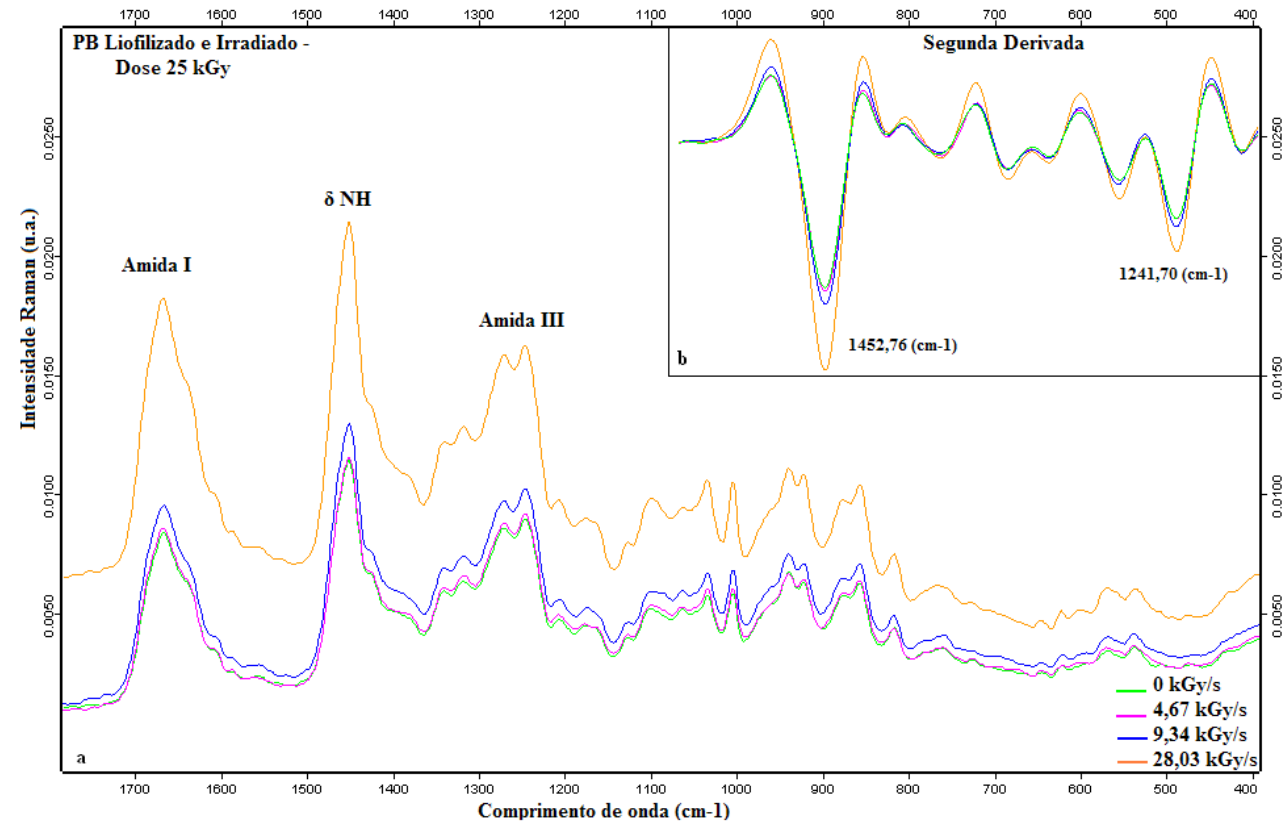

Figura 11. Espectro Raman das principais estruturas do PB. Amostras de pericárdio bovino liofilizado e irradiado na dose de 25 kGy e em diferentes taxas de dose. 
Neste estudo preliminar, cujo objetivo foi verificar os efeitos da irradiação em amostras liofilizadas de pericárdio bovino, observou-se um aumento da $\mathrm{Tg}$. Estes resultados sugerem que após a irradiação das amostras na dose de 25 kGy, nas taxas de dose de 4,67 e 9,34 kGy/s, pode ter ocorrido a formação de ligação cruzada (crosslink) no tecido do PB entre as fibras de colágeno. Para os outros parâmetros de irradiação utilizados foi possível observar a diminuição da Tg, ou seja, houve um favorecimento para a cisão da cadeia. A fim de confirmar estes resultados preliminares, realizou-se o teste de intumescimento (swelling). Além disso, a microscopia eletrônica de varredura (MEV) dessas amostras foi utilizada para verificar os efeitos da irradiação no tecido de PB.

\subsubsection{Teste de intumescimento}

O teste de intumescimento ou de swelling, neste trabalho, foi aplicado para verificar o grau de absorção de água pela amostras em função das doses de irradiação aplicadas. Para a realização do teste de intumescimento, novas amostras foram irradiadas.

De acordo com os dados preliminares obtidos por DSC, os resultados mais promissores foram obtidos a partir da irradiação do tecido de PB na dose de 25 kGy, nas taxas de dose de 4,67 e 9,34 kGy/s. Se observado o desvio da média para estes valores, é possível dizer que estes se equivalem. Portanto, para os testes seguintes, foi estabelecida a taxa de dose de 4,67 kGy/s variando-se a dose. Algumas doses foram escolhidas teoricamente para a aplicação sobre o material (5, 12,5, 20, 25 e 30 kGy).

Na prática, após a liofilização as amostras foram irradiadas nas doses de 0, 6,25, 12,5, 20,83, 25 e 31,25 kGy, utilizando-se a taxa de dose de 4,67 kGy/s. Posteriormente, as amostras foram submetidas ao teste de intumescimento (Figura 12) e captação de imagens por microscopia eletrônica por varredura (Figuras 13-15). 


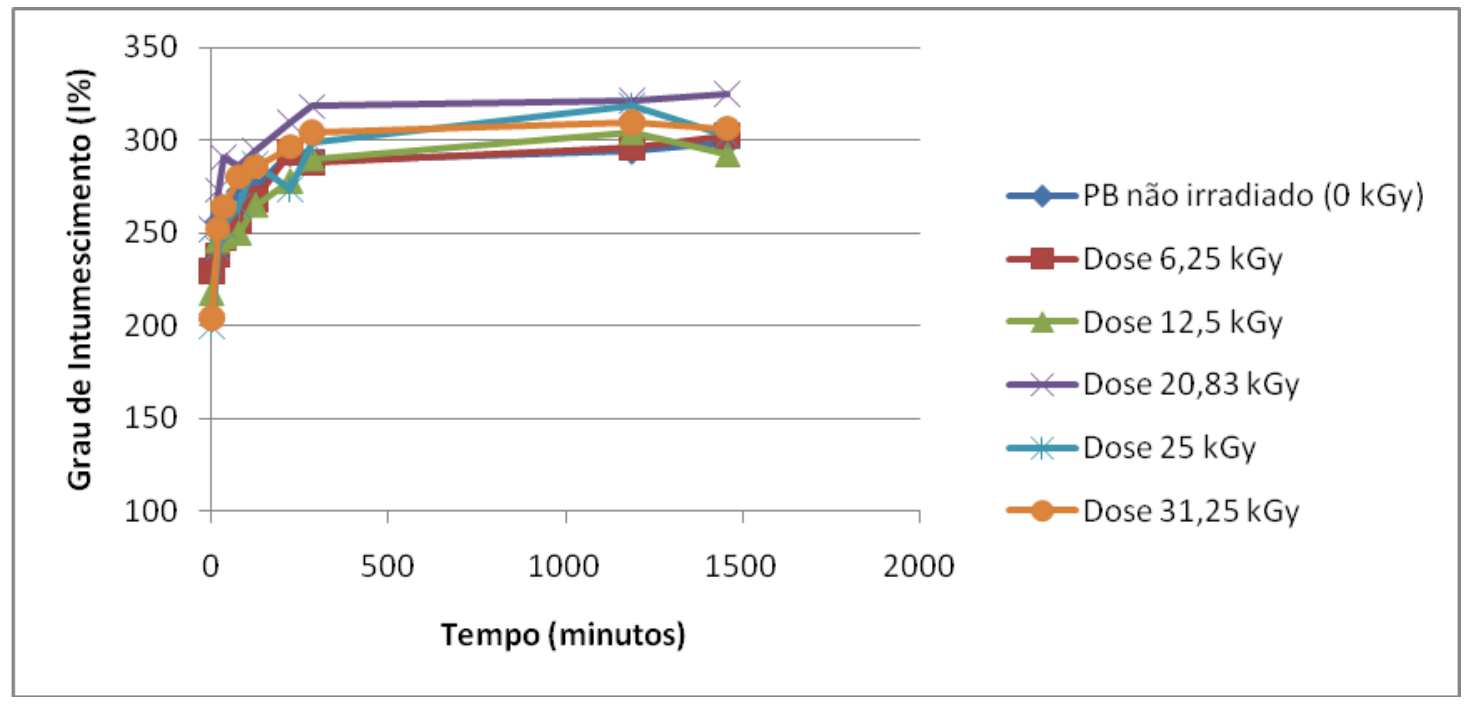

Figura 12. Cinética de intumescimento das amostras de PB liofilizadas e irradiadas na presença de oxigênio utilizando uma taxa de dose de 4,67 kGy/s.

De acordo com o gráfico de intumescimento pode-se observar que todas as amostras irradiadas de PB absorveram maior porcentagem de água ao final do experimento, quando comparadas com as amostras não irradiadas. Isto indica que houve um maior espaço para que o tecido absorva mais água. Portanto, o que podemos dizer a partir desses resultados é que pode ter ocorrido à cisão de uma pequena parte da estrutura do colágeno presente nas amostras de PB irradiadas, deixando o tecido fica mais frouxo $\mathrm{e}$ consequentemente permitindo uma maior entrada de água. Ainda, observando o gráfico, podemos verificar que as doses de 6,25 e 12,5 kGy parecem não modificar consideravelmente a estrutura do tecido de PB, já que houve pouca variação do grau de intumescimento. Já a dose de 20,83 kGy parece ser a dose que mais modificou o tecido de PB, deixando o tecido com um maior espaço interno, levando a uma maior absorção de água. 


\subsubsection{Microscopia eletrônica de varredura (MEV)}

A microscopia eletrônica de varredura permite a obtenção de imagens de superfícies lisas ou rugosas, com alta resolução e de aparência tridimensional. Portanto, esta é uma ferramenta muito importante para o estudo da microestrutura e, com isso verificar a presença de defeitos no material. $\mathrm{Na}$ figura abaixo (Figura 13) estão as imagens captadas por MEV referentes ao lado rugoso das amostras de PB. Observando-se a figura 13-A, pode-se verificar a estrutura intacta do PB não irradiado (0 kGy). Também é possível observar que a irradiação parece não alterar significativamente a estrutura do pericárdio bovino quando se utiliza a dose de 6,25 kGy (Figura 13-B), pois não são observadas alterações visíveis através das imagens captadas (500 vezes). A partir da dose de 12,5 kGy há alterações em todas as amostras, sendo possível observar que superficialmente, algumas fibras de colágeno presentes no tecido de $\mathrm{PB}$, ao serem irradiadas, parecem ter sido rompidas e depois enroladas desordenadamente (indicados com as setas). Entretanto, é possível que ocorra, em paralelo, ligações entre as cadeias de colágeno presentes no tecido. Ao observar a figura referente à dosagem de 20,83 kGy (Figura 13-D), esta parece ser a dose que mais alterou o tecido de PB. Estes dados confirmam os resultados acima descritos obtidos com teste de intumescimento. 


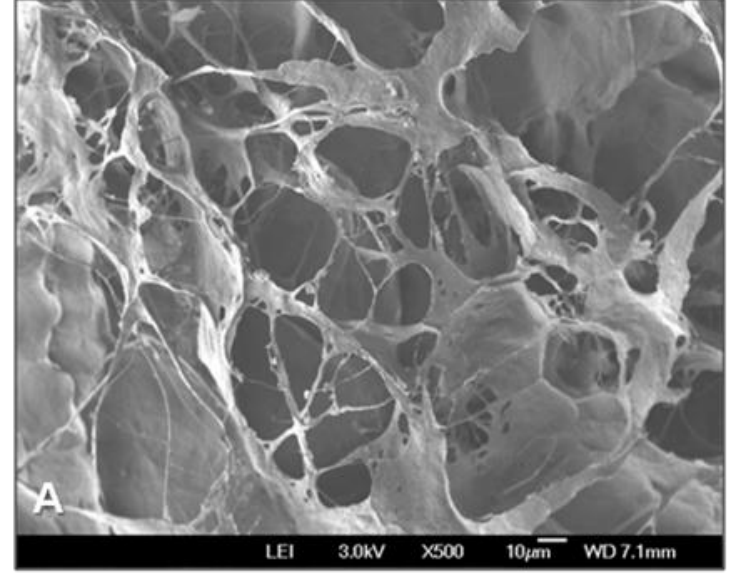

$0 \mathrm{kGy}$

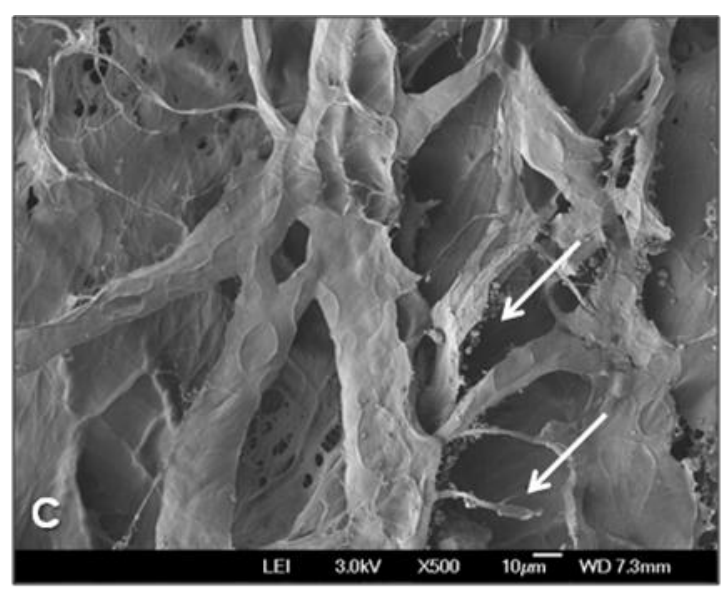

$12,50 \mathrm{kGy}$

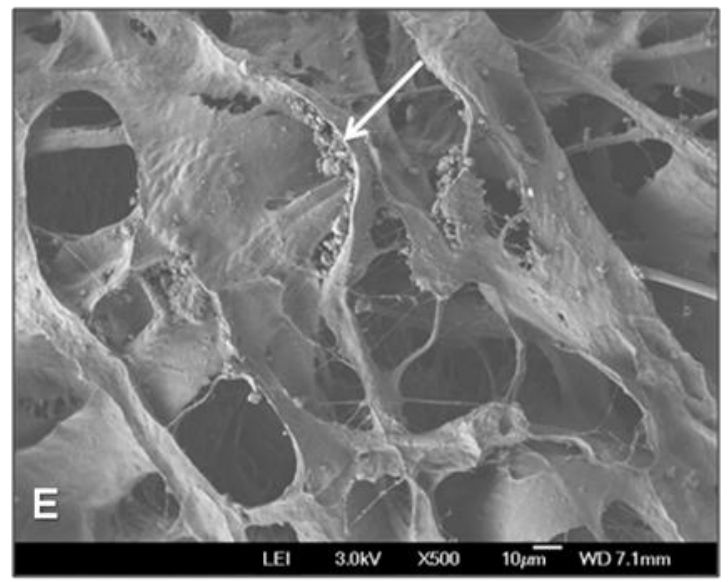

25,0 kGy

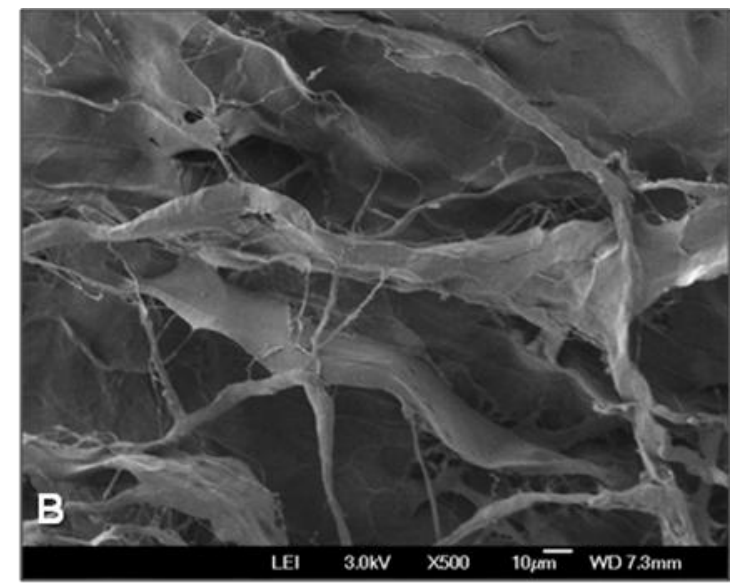

$6,25 \mathrm{kGy}$

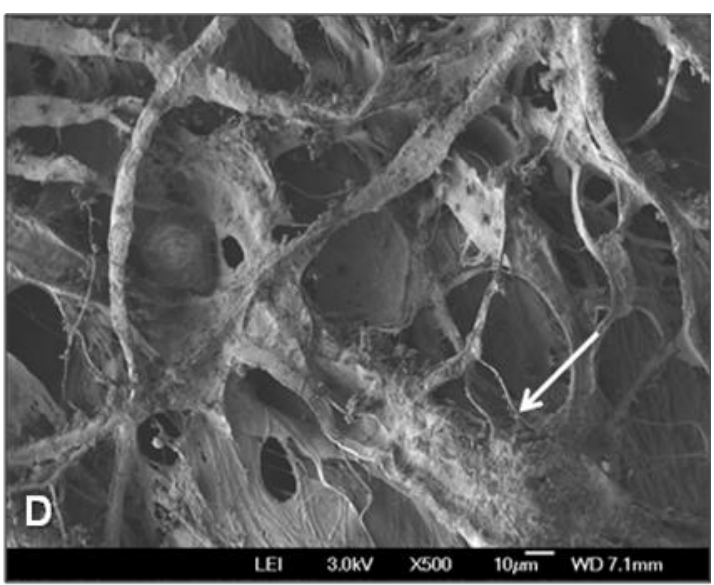

20,83 kGy

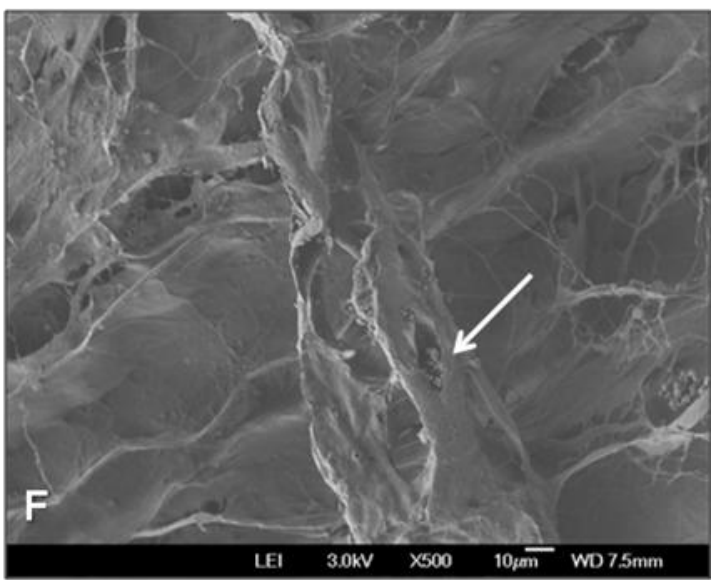

$31,25 \mathrm{kGy}$

Figura 13. Micrografias referentes ao lado rugoso das amostras liofilizadas e irradiadas com uma taxa de dose de 4,67 kGy/s, na presença de oxigênio, utilizando-se o aumento de 500 vezes. As principais alterações no tecido estão indicadas por setas. 


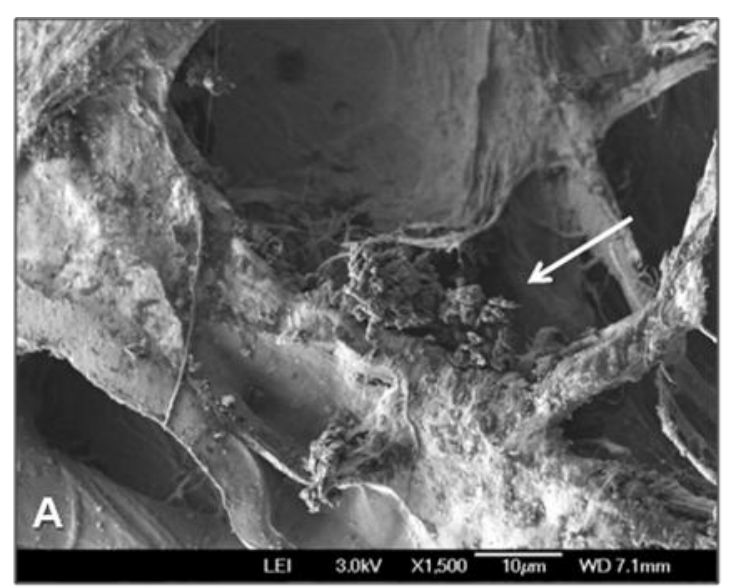

$20,83 \mathrm{kGy}$

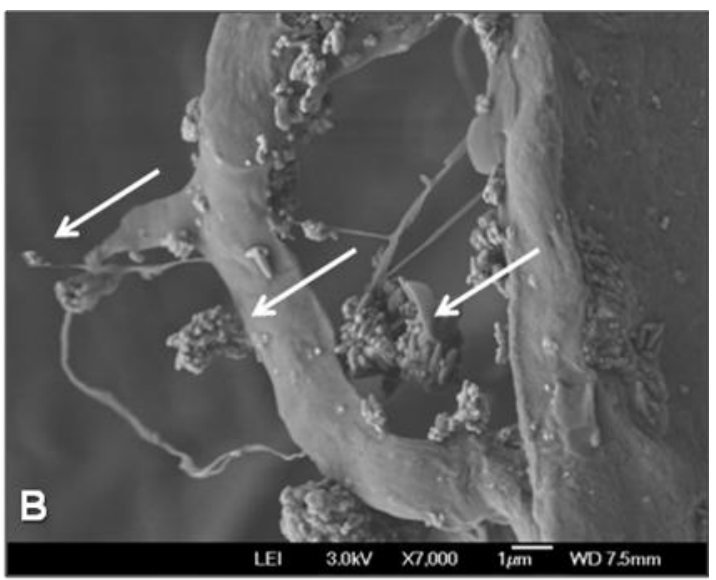

$31,25 \mathrm{kGy}$

Figura 14. Micrografias referentes ao lado rugoso das amostras de PB liofilizadas e irradiadas na presença de oxigênio obtidas por MEV. (A) referente à amostra irradiada na dose de 20,83 kGy com aumento de 1.500 vezes. (B) - referente à amostra irradiada na dose de 31,25 kGy com aumento de 7.000 vezes. As principais alterações no tecido estão indicadas por setas.

A Figura 14 mostra mais detalhadamente as alterações sofridas pelo tecido de PB irradiado. A figura 14-A mostra em um aumento de 1500 vezes a amostra irradiada a uma dose de 20,83 kGy e a figura 14-B em um aumento de 7000 vezes a amostra irradiada na maior dose (31,25 kGy). Em ambas as micrografias verificam-se aglomerados (indicados por setas) que possivelmente são resultantes da quebra das cadeias de colágeno devido à irradiação e posterior enrolamento desordenado.

Observando-se a micrografia referente ao lado liso (Figura 15) das amostras de PB, é possível verificar a integridade do tecido para todas as amostras irradiadas nas doses de 0,12,5, 25 kGy. Já na maior dose aplicada, de 31,25 kGy, é possível verificar que esta dose de irradiação altera bastante o tecido do lado liso, deixando-o aparentemente com alguns poros. Apesar destes defeitos encontrados nos tecidos irradiados poderem ser encontrados eventualmente em tecidos não tratados, durante a execução destes testes 
observou-se que após a irradiação estas alterações eram frequentemente encontradas.

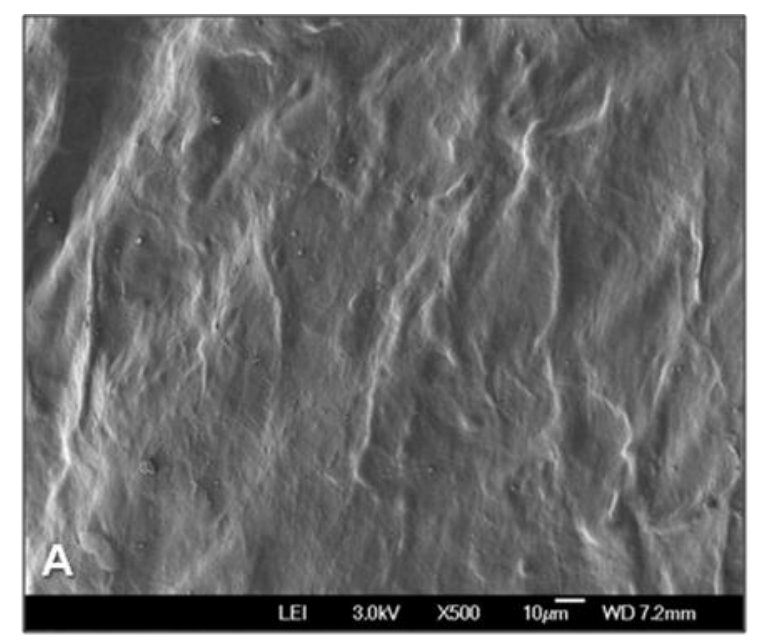

$0 \mathrm{kGy}$

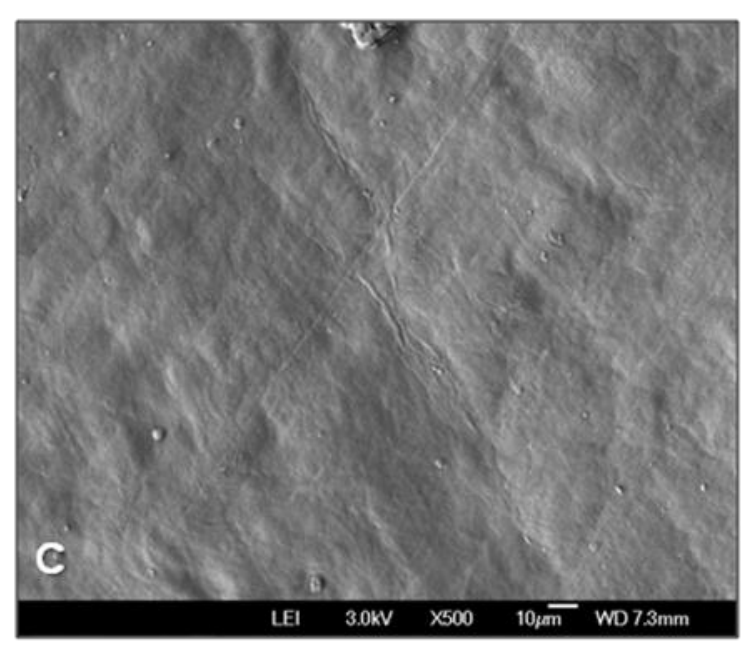

$25 \mathrm{kGy}$

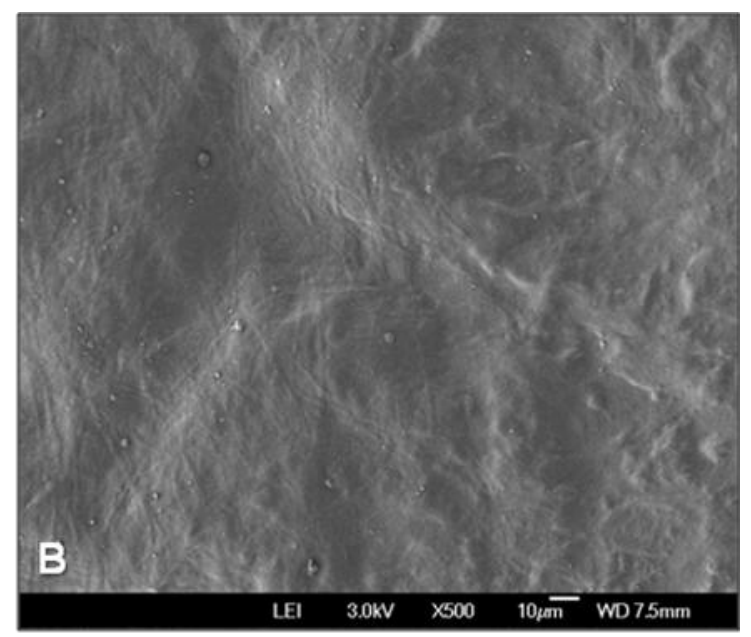

$12,5 \mathrm{kGy}$

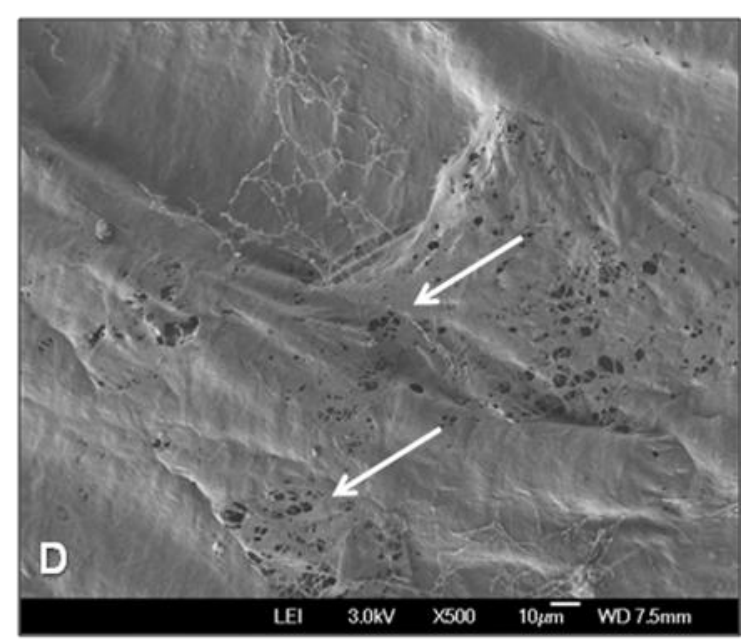

$31 \mathrm{kGy}$

Figura 15. Micrografias referentes ao lado liso das amostras liofilizadas e irradiadas na presença de oxigênio obtidas por MEV, utilizando-se o aumento de 500 vezes. As principais alterações no tecido estão indicadas por setas.

As micrografias mostradas acima (Figuras 13-15) foram coletadas das amostras irradiadas e embaladas em polietileno e seladas em seladora a vácuo. Porém observou-se que a espessura do plástico não era suficiente para 
a seladora criar vácuo nas embalagens, deixando as amostras livres no plástico (sem vácuo).

A partir das análises realizadas foi possível verificar que a irradiação por feixe de elétrons parece alterar o tecido de pericárdio bovino. Através das análises por MEV observa-se que possivelmente houve um rompimento superficial de algumas fibras de colágeno, que são abundantes no tecido, e que posteriormente se enrolaram de forma desordenada. Isto pode ter ocorrido devido à presença de oxigênio que ficou contida na embalagem. A presença de oxigênio durante a irradiação tem papel importante na radiólise do material. Inicialmente, com uma pequena quantidade de água proveniente da umidade residual do material (cerca de 14\%), pode ser gerado radical hidroxila, peróxido de hidrogênio e o elétron-aquoso. Após essa etapa, o elétron-aquoso reage com o oxigênio molecular $\left(\mathrm{O}_{2}\right)$ e forma o íon superóxido. Essas espécies reativas darão início a reações químicas radicalares e, modificarão a estrutura química do material. Portanto, o oxigênio molecular pode interferir na reticulação (crosslinking) e aumentar a cisão das cadeias. Uma característica que pode ser observada quando ocorre a degradação ou quebra parcial das cadeias de colágeno é o aumento do grau de intumescimento do colágeno (SWALLOW, 1960; WOODS; PIKAEV, 1994).

O efeito do oxigênio durante a irradiação do PB liofilizado pôde ser verificado após a irradiação das amostras nos mesmos parâmetros anteriores de irradiação, porém irradiadas na ausência de oxigênio. Para isso utilizou-se uma embalagem do mesmo material (PEBD), porém de espessura superior (90 $\mu \mathrm{m})$ a da embalagem anterior (50 $\mu \mathrm{m})$. Esta embalagem, por ser mais espessa que a anterior foi capaz de criar vácuo dentro da embalagem, o que não se observava anteriormente, pois o plástico era muito fino para a seladora criar vácuo. Depois de liofilizadas e embaladas sob vácuo as amostras foram irradiadas utilizando-se os mesmos parâmetros anteriores de dose e taxa de dose e posteriormente analisadas. 


\subsubsection{Teste de intumescimento para amostras irradiadas sob vácuo}

Como pode-se observar nas figuras 16 e 17, referentes ao intumescimento das amostras irradiadas a vácuo, todas as doses e taxas de dose aplicadas às amostras parecem alterar o tecido do PB. Todas as amostras irradiadas, quando comparadas com o PB não irradiado, absorveram menos água, sugerindo que a irradiação realizada com a embalagem à vácuo, ou seja, na ausência de oxigênio, deixa o tecido mais compactado. Esses resultados nos sugerem uma reticulação do tecido de PB. Ainda observando-se o gráfico abaixo (Figura 16) é possível verificar que o intumescimento no tecido parece ser menor quanto maior as taxas de dose aplicadas.

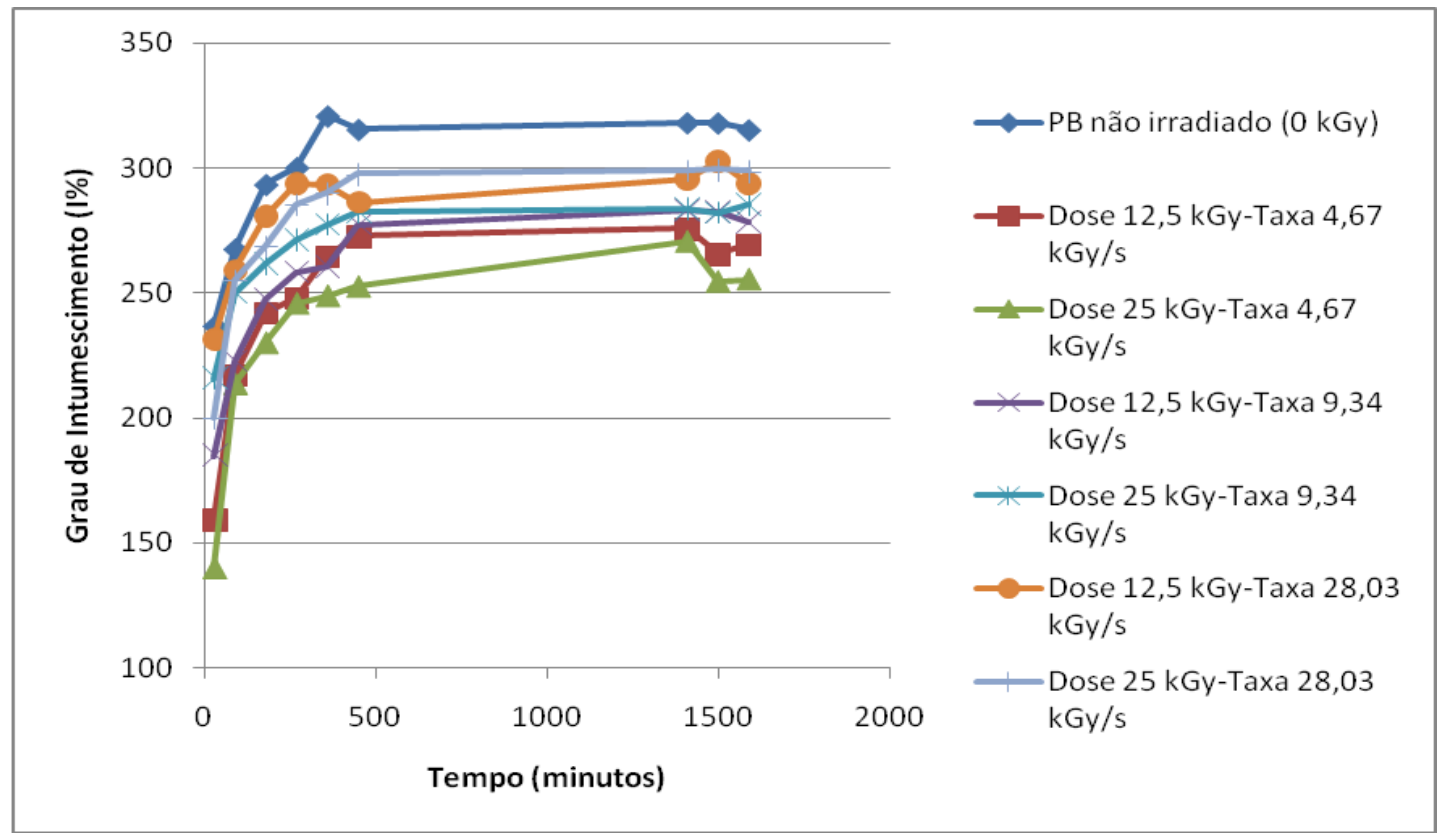

Figura 16. Cinética de intumescimento das amostras de PB liofilizadas e irradiadas à vácuo utilizando-se duas doses (12,5 e 25 kGy) diferentes para cada taxa de dose aplicada (4,67, 9,34 e 28,03 kGy/s). 


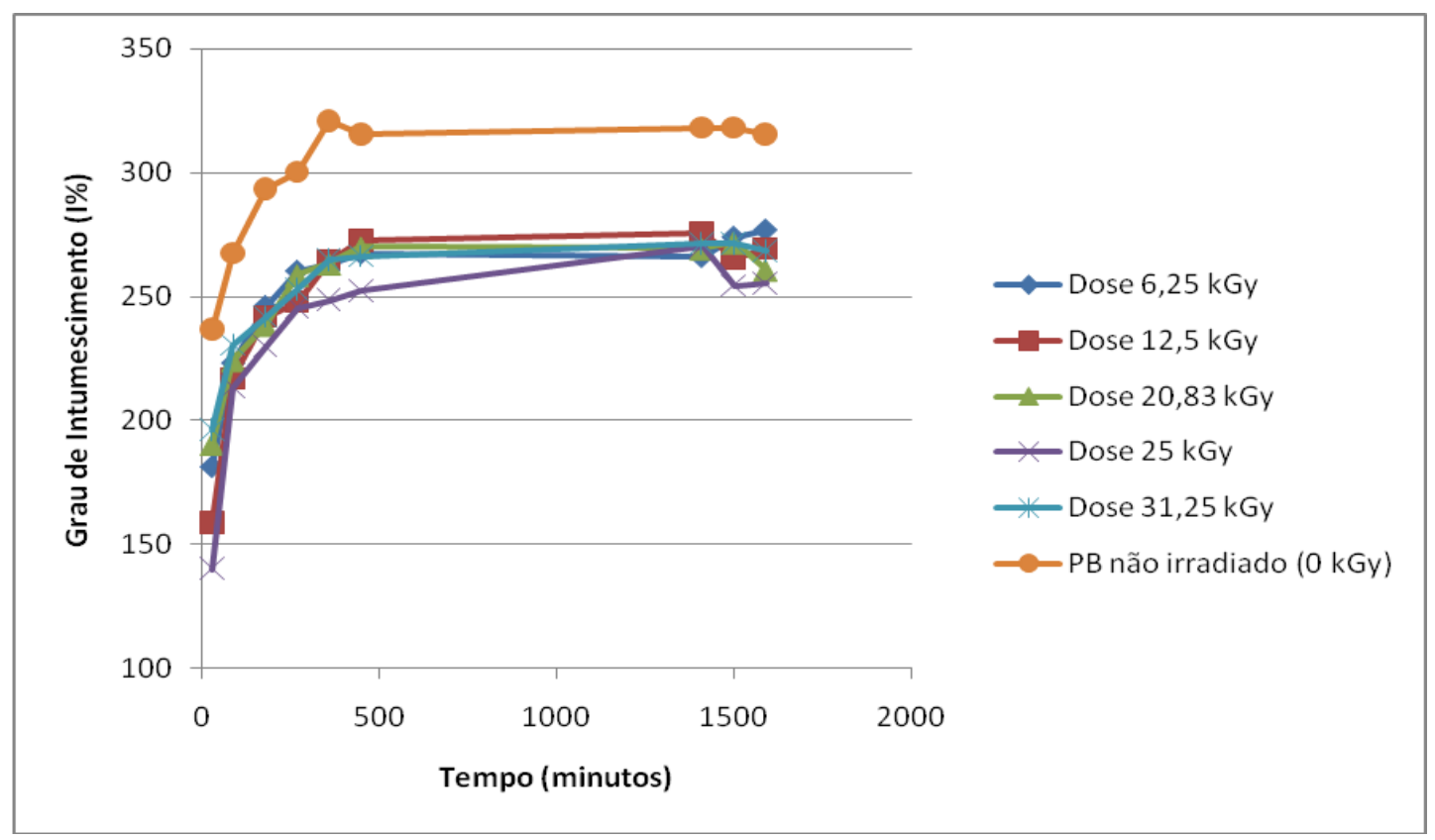

Figura 17. Cinética de intumescimento das amostras de PB liofilizadas e irradiadas à vácuo, utilizando-se uma taxa de dose de 4,67 kGy/s e cinco diferentes doses de irradiação $(6,25,12,5,20,83,25$ e 31,25 kGy).

Observando-se a figura 17, referente ao intumescimento das amostras irradiadas com a taxa de dose de 4,67 kGy/s, é possível concluir somente que as alterações causadas em relação à esta taxa de dose deixa o tecido mais compactado que todas as outras doses aplicadas, pois todas possuem um menor grau de intumescimento ( $1 \%$ ) em relação ao PB não irradiado (0 kGy). Entretanto, não é possível verificar por meio deste teste qual dose aplicada causa uma maior alteração ao tecido, pois os dados são muito próximos. Analisando-se estatisticamente (ANOVA) os valores obtidos pelo intumescimento das amostras irradiadas com e sem $\mathrm{O}_{2}$ foi possível verificar que não houve variação significativa $(p>0,05)$ das amostras analisadas entre os tempos de pesagem em 1410, 1500 e 1590 minutos. Ainda pode-se concluir que o intumescimento é significativamente influenciado $(p<0,05)$ de acordo com a presença de $\mathrm{O}_{2}$ durante a irradiação, sendo que o valor de intumescimento é maior para as amostras irradiadas na presença de $\mathrm{O}_{2}$. 


\subsubsection{Microscopia eletrônica de varredura das amostras irradiadas sob} vácuo

Micrografias das amostras irradiadas sob vácuo também foram obtidas. Como é possível observar nas micrografias referente ao lado rugoso (Figuras 18 e 19), todas as doses aplicadas, independentemente da taxa de dose, parecem alterar bruscamente a estrutura do PB deixando-o mais compactado, corroborando com os resultados obtidos pelo teste de intumescimento, fazendo com que o tecido absorva menos água. Os aglomerados que são observados nas amostras irradiadas na presença de $\mathrm{O}_{2}$, também existem, porém em quantidades bem inferiores (indicados com setas).

Observando-se a Figura 18-D, em relação às outras micrografias da figura 18, esta parece ser a dose de irradiação que levou a maior compactação do tecido. 


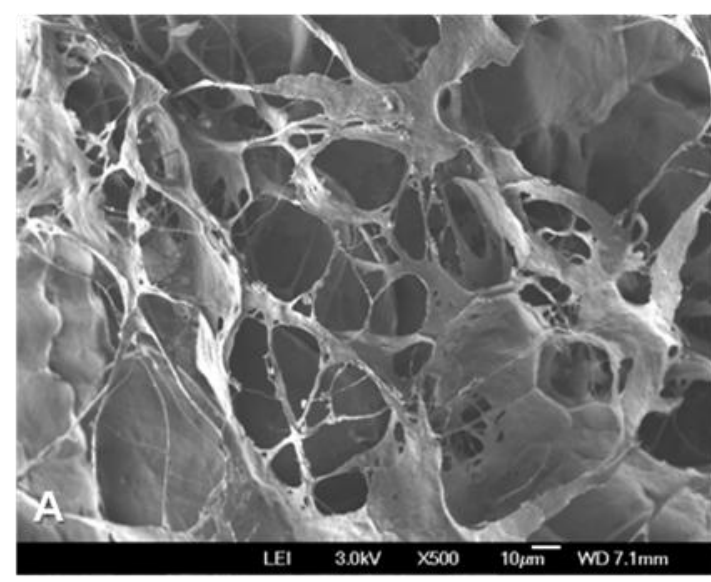

$0 \mathrm{kGy}$

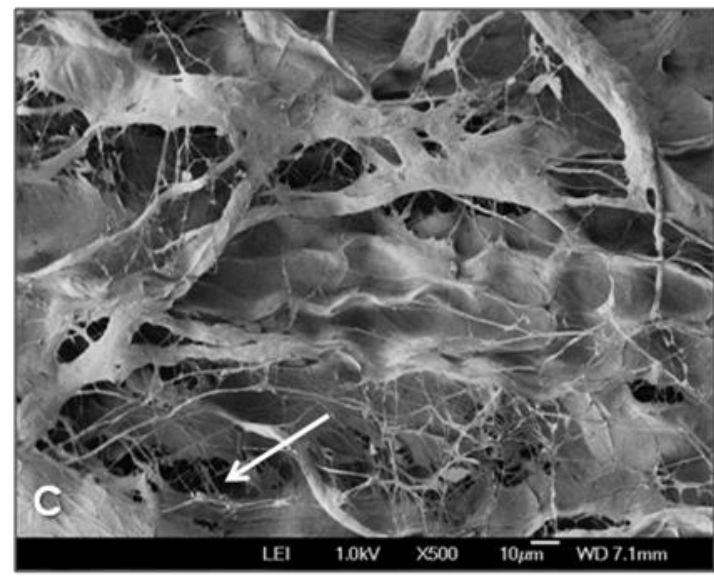

$12,5 \mathrm{kGy}$

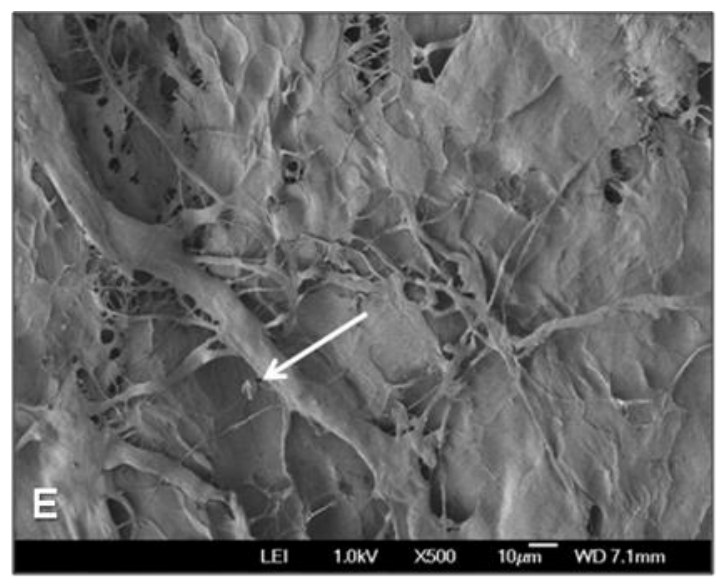

$25 \mathrm{kGy}$

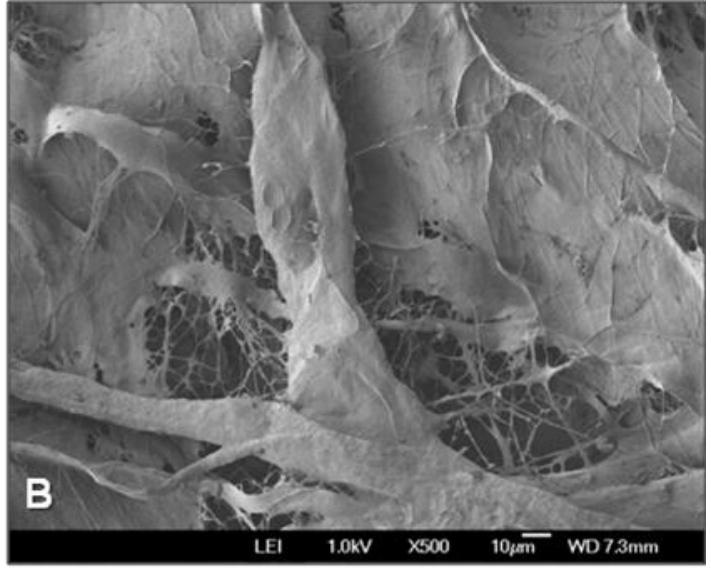

$6,25 \mathrm{kGy}$

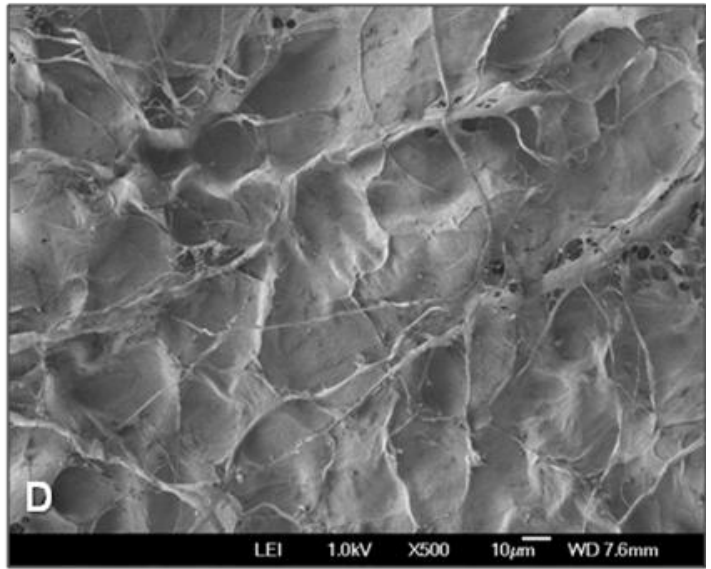

20,83 kGy

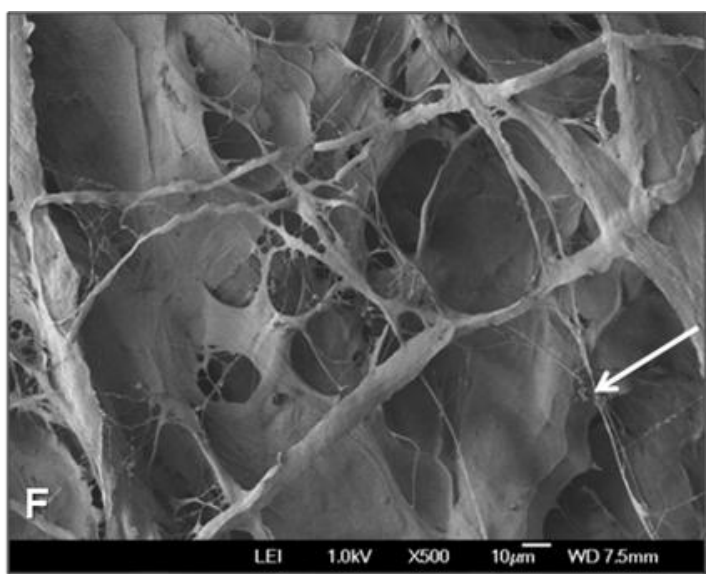

$31,25 \mathrm{kGy}$

Figura 18. Micrografias referentes ao lado rugoso das amostras liofilizadas e irradiadas sob vácuo utilizando-se uma taxa de dose de 4,67 kGy/s, utilizandose aumento de 500 vezes. As principais alterações no tecido estão indicadas por setas. 


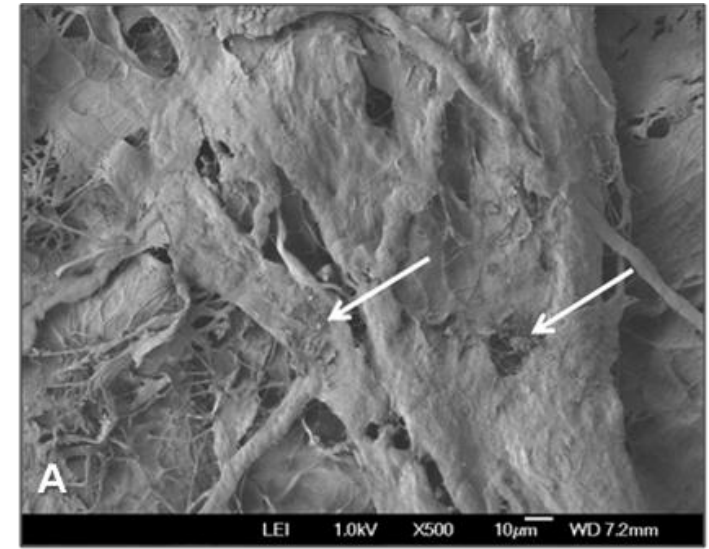

9,34 kGy/s - 12,5 kGy

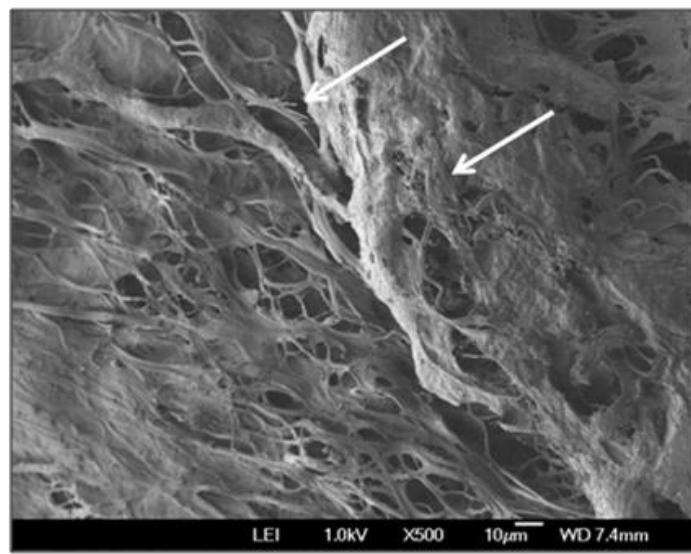

$28,03 \mathrm{kGy} / \mathrm{s}-12,5 \mathrm{kGy}$

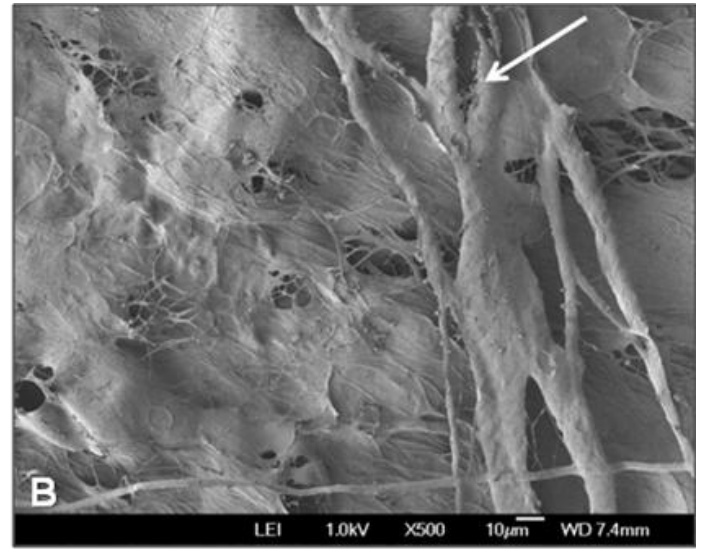

9,34 kGy/s - 25 kGy

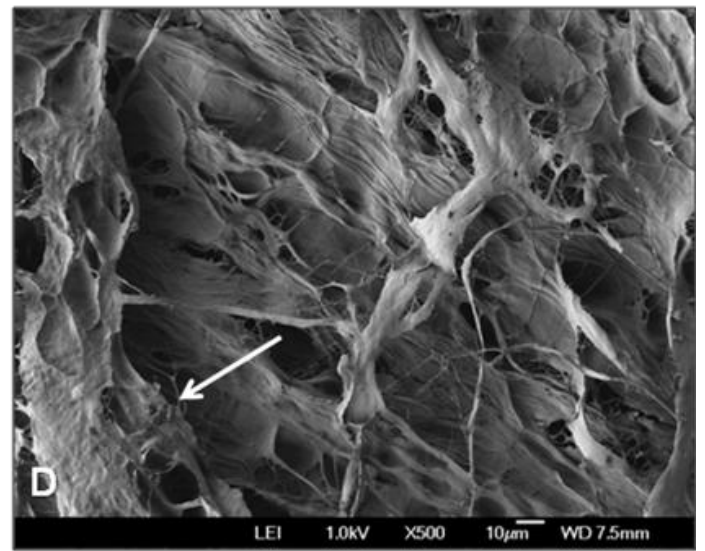

$28,03 \mathrm{kGy} / \mathrm{s}-25 \mathrm{kGy}$

Figura 19. Micrografias referentes ao lado rugoso das amostras liofilizadas e irradiadas sob vácuo obtidas por MEV, utilizando-se aumento de 500 vezes. As principais alterações no tecido estão indicadas por setas.

De acordo com as micrografias obtidas (Figuras 18 e 19) em relação ao gráfico de intumescimento (Figura 17), que compara as três taxas de dose empregadas (4,67, 9,34 e 28,03 kGy/s) em duas diferentes doses (12,5 e 25 kGy), verifica-se que a maior taxa aplicada (28,03 kGy/s) alterou bastante o tecido deixando-o mais frouxo em relação ao irradiado na taxa de dose de 9,34 kGy/s o que permitiu uma maior absorção de água.

As alterações no tecido do lado liso, aplicando-se a taxa de dose de 4,67 kGy/s (Figura 20) podem ser observadas (indicadas com setas) principalmente nas doses de 20,83 e 31,25 kGy, onde encontramos no tecido fissuras e alguns aglomerados. Porém a irradiação realizada a vácuo na dose de 31,25 kGy não parece deixar o tecido do lado liso com defeitos que aumentam porosidade, 
como ocorreu na irradiação na presença de oxigênio. Observando-se a figura 21, referente às taxas de dose 9,34 e 28,03 kGy/s e às doses de 12,5 e 25 kGy, verifica-se que quanto maior a taxa de dose aplicada, maior a alteração causada ao tecido do lado liso. Isto ocorre pois a taxa de dose determina o quanto (tempo) que a amostra ficará exposta no feixe para receber a dose prédeterminada. Quanto maior esta taxa de dose maior a dose recebida em uma única vez e, portanto esta amostra sofrerá um maior aquecimento, levando a maior degradação no tecido. Portanto a partir destes resultados resolvemos investigar, com o auxílio de outras técnicas, os efeitos da irradiação no tecido de PB aplicando-se as duas menores taxas de dose. 


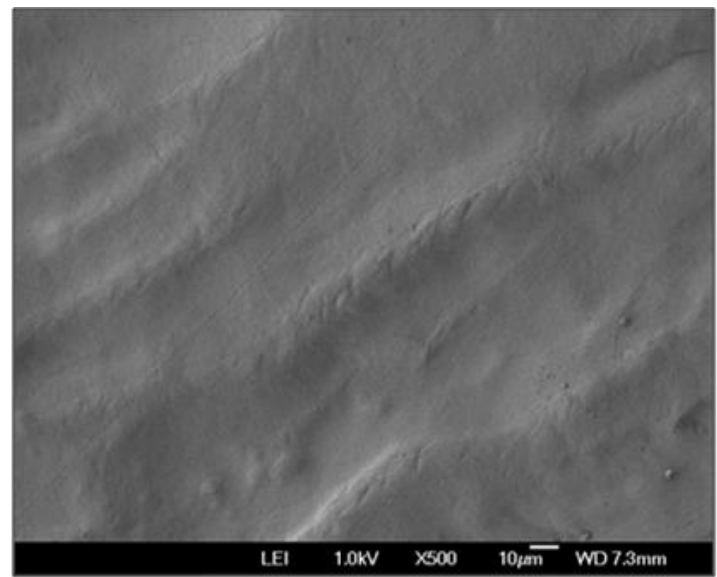

$6,25 \mathrm{kGy}$

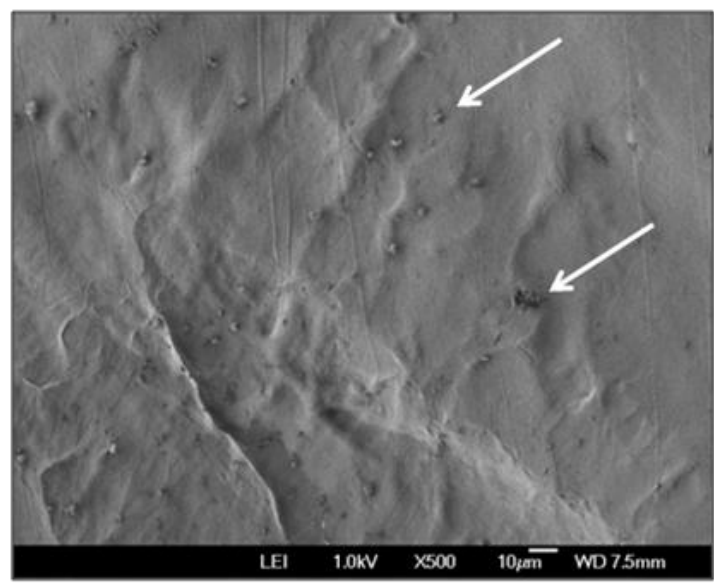

20,83 kGy

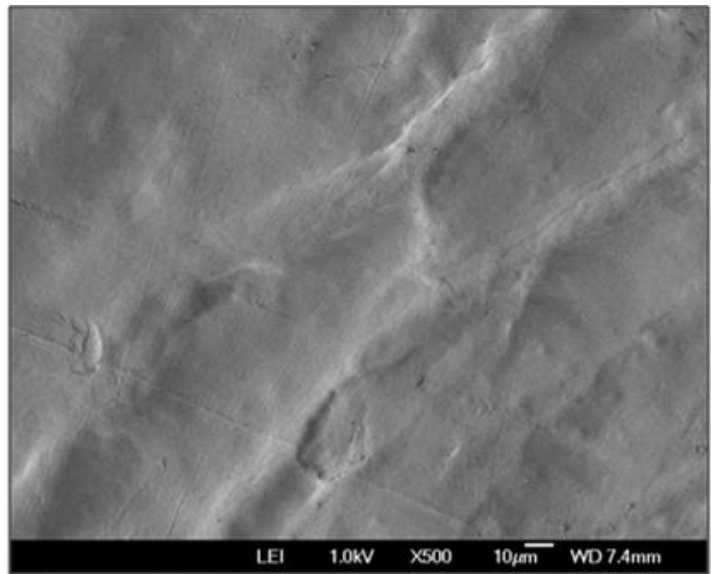

12,5 kGy

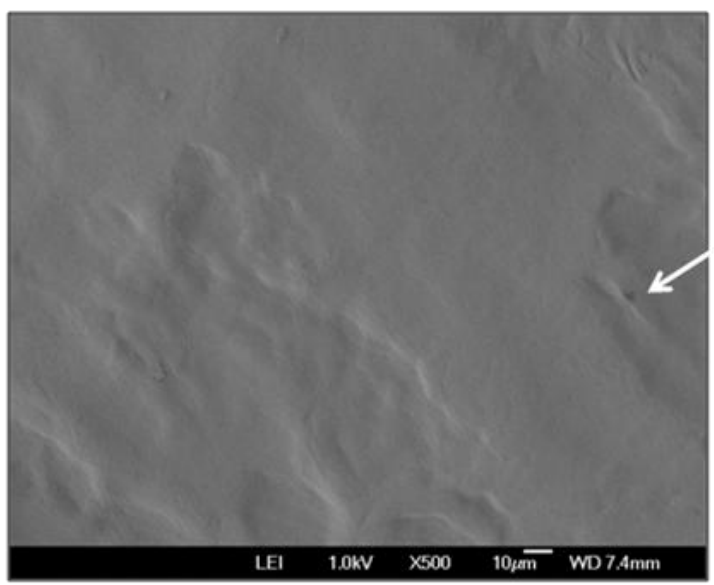

$25 \mathrm{kGy}$

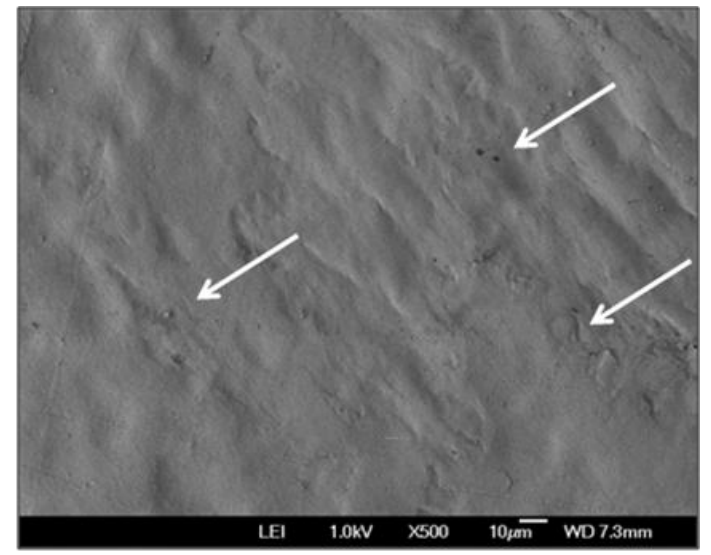

$31,25 \mathrm{kGy}$

Figura 20. Micrografias referentes ao lado liso das amostras liofilizadas e irradiadas com taxa de dose de 4,67 kGy/s, utilizando-se aumento de 500 vezes. As principais alterações no tecido estão indicadas por setas. 


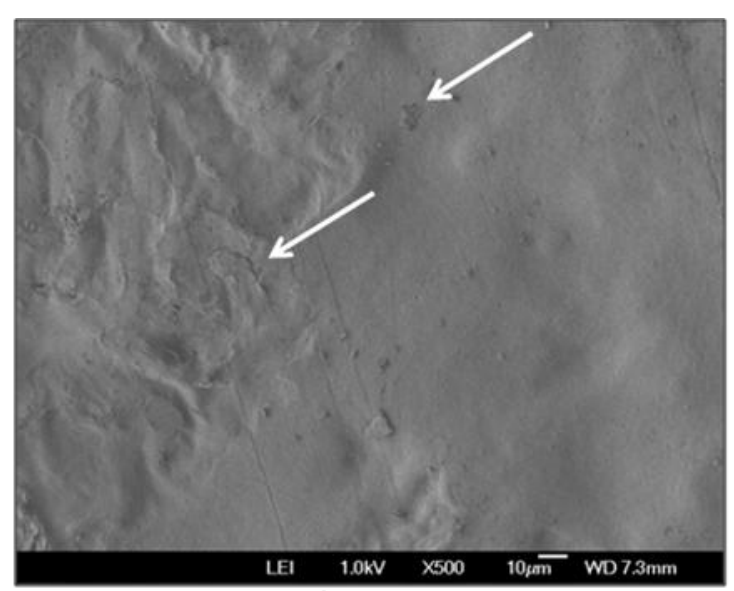

$9,34 \mathrm{kGy} / \mathrm{s}-12,5 \mathrm{kGy}$

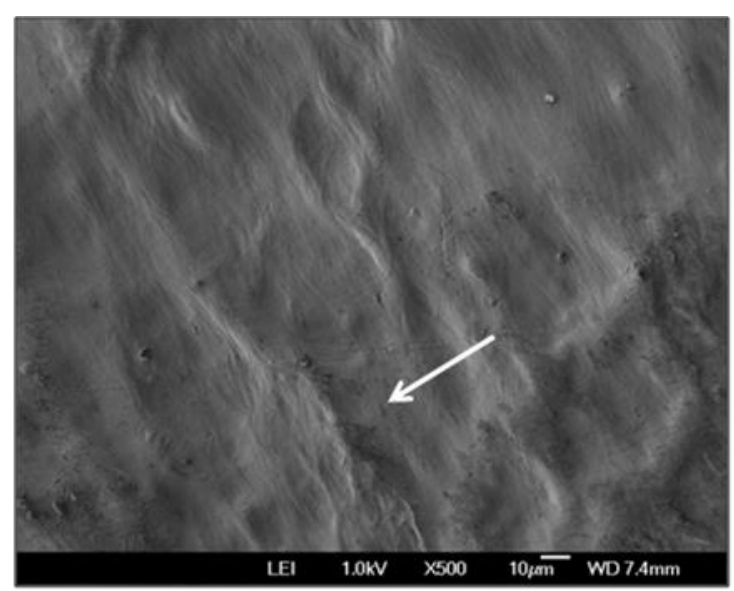

$28,03 \mathrm{kGy} / \mathrm{s}-12,5 \mathrm{kGy}$

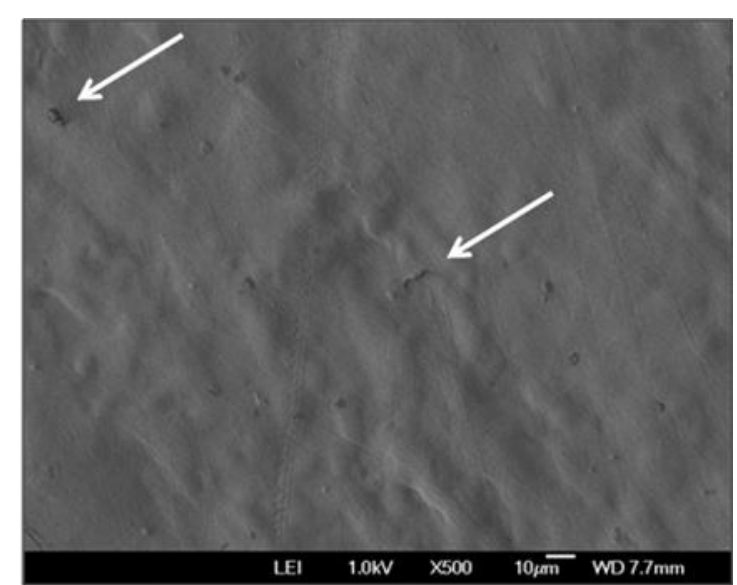

$9,34 \mathrm{kGy} / \mathrm{s}-25 \mathrm{kGy}$

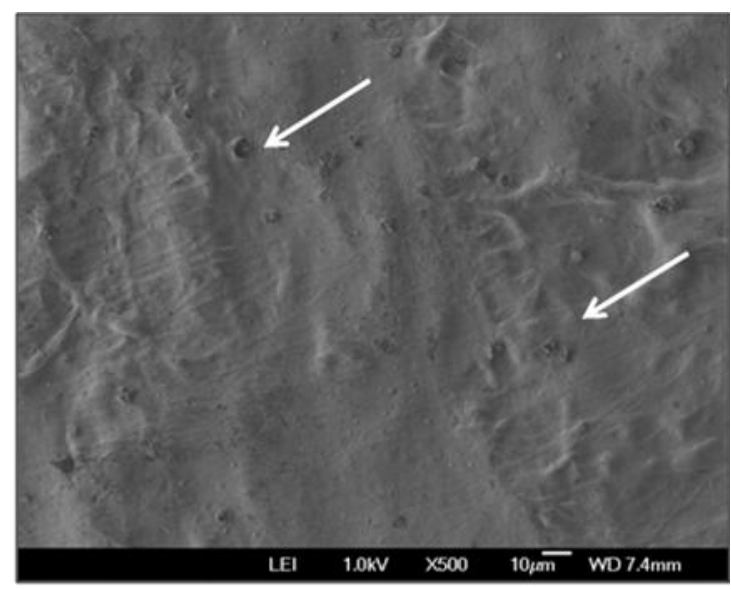

$28,03 \mathrm{kGy} / \mathrm{s}-25 \mathrm{kGy}$

Figura 21. Micrografias referentes ao lado liso das amostras liofilizadas e irradiadas de PB obtidas por MEV, utilizando-se o aumento de 500 vezes. As principais alterações no tecido estão indicadas por setas.

\subsubsection{Análise termogravimétrica}

A termogravimetria é um método que permite determinar continuamente a massa da amostra durante o processo de aquecimento. É possível observar a região de temperatura onde a perda de massa acontece, e quantificá-la. A TGA é uma técnica bastante aplicada em polímeros para investigar reações como desidratação, decomposição, oxidação, evaporação e adsorção. As curvas de perda de massa são registradas em porcentagem versus temperatura. Com a primeira derivada destas curvas podemos obter melhor 
informação quanto ao início ou término de cada evento, e se o evento ocorre em uma ou mais etapas (EHRENSTEIN; RIEDEL;TRAWIEL, 2004).

De acordo com os espectros obtidos por termogravimetria, o comportamento térmico tanto do controle (0 kGy) quanto das amostras irradiadas sob vácuo é caracterizado por três estágios de perda de massa. 0 primeiro, que ocorre na faixa de 25 até $200^{\circ} \mathrm{C}$, está relacionado com a perda de água do material (13\%). O segundo estágio ocorre na faixa de temperatura de 200 a $450^{\circ} \mathrm{C}$ e está relacionado com a degradação da estrutura do colágeno $(40,94 \%)$. A terceira fase, que ocorre na temperatura de 450 a $650^{\circ} \mathrm{C}$ se relaciona à combustão dos compostos orgânicos residuais (39,09\%). Estes dados estão de acordo com Batista et al. (2009). Portanto podemos afirmar que estes três estágios estão relacionados com três eventos distintos como é possível observar na derivada obtida de cada amostra, onde cada pico corresponde a um evento. Após o termino das análises foi observado um valor médio aproximado de 7\% de resíduos, calculado de acordo com as curvas. Este resíduo pode ser atribuído ao sal presente na solução salina na qual as peças de PB são lavadas para remoção de glicerol. A pequena variação observada entre as curvas pode ter ocorrido devido às pequenas diferenças de massas entre as amostras analisadas. A tabela 3 mostra os valores referentes às três etapas obtidas das curvas de cada amostra (Figuras 22-25). Entretanto, as alterações causadas no tecido não foram significativas para que fossem detectadas com a utilização desta técnica. Portanto, resolvemos utilizar a técnica de DSC para investigar melhor as alterações causadas no tecido. 
Tabela 4. Perda de massa das três etapas obtidas por TGA.

\begin{tabular}{|c|c|c|c|}
\hline Amostra & $\begin{array}{l}\text { Perda de } \\
\text { água (\%) }\end{array}$ & $\begin{array}{c}\text { Degradação } \\
\text { do } \\
\text { colágeno } \\
\text { (\%) }\end{array}$ & $\begin{array}{c}\text { Combustão do } \\
\text { residual orgânico } \\
(\%)\end{array}$ \\
\hline Controle & 13,6 & 41,3 & 40,2 \\
\hline Dose 12,5 - Taxa 4,67 & 13,5 & 40,5 & 39,2 \\
\hline Dose 25 - Taxa 4,67 & 11,8 & 42 & 37,1 \\
\hline Dose 12,5 - Taxa 9,34 & 12,1 & 40,8 & 40,6 \\
\hline Dose 25 - Taxa 9,34 & 13 & 40,7 & 38,8 \\
\hline
\end{tabular}

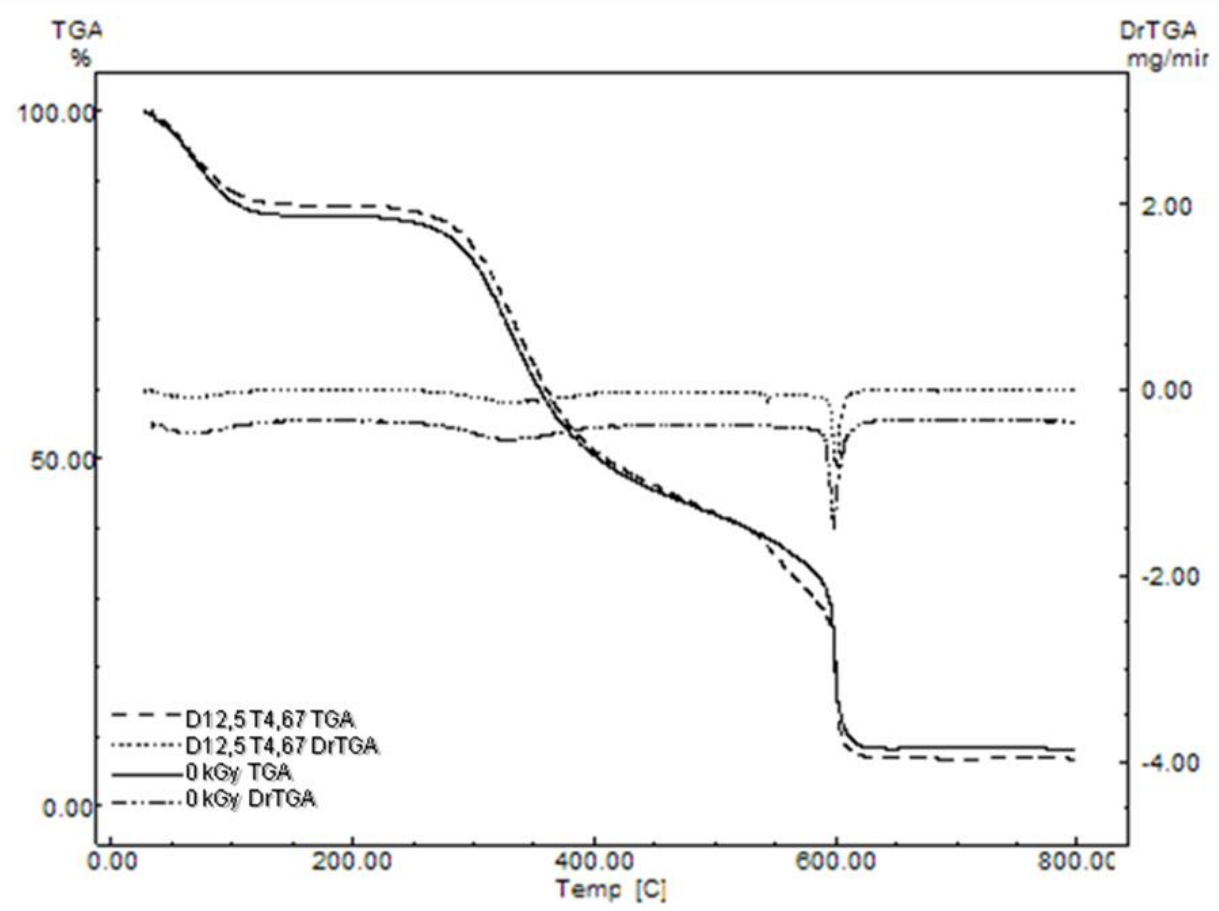

Figura 22. Curvas termogravimétricas e respectivas derivadas das amostras de PB não irradiado e PB irradiado na dose de 12,5 kGy, taxa de dose de 4,67 kGy/s. 


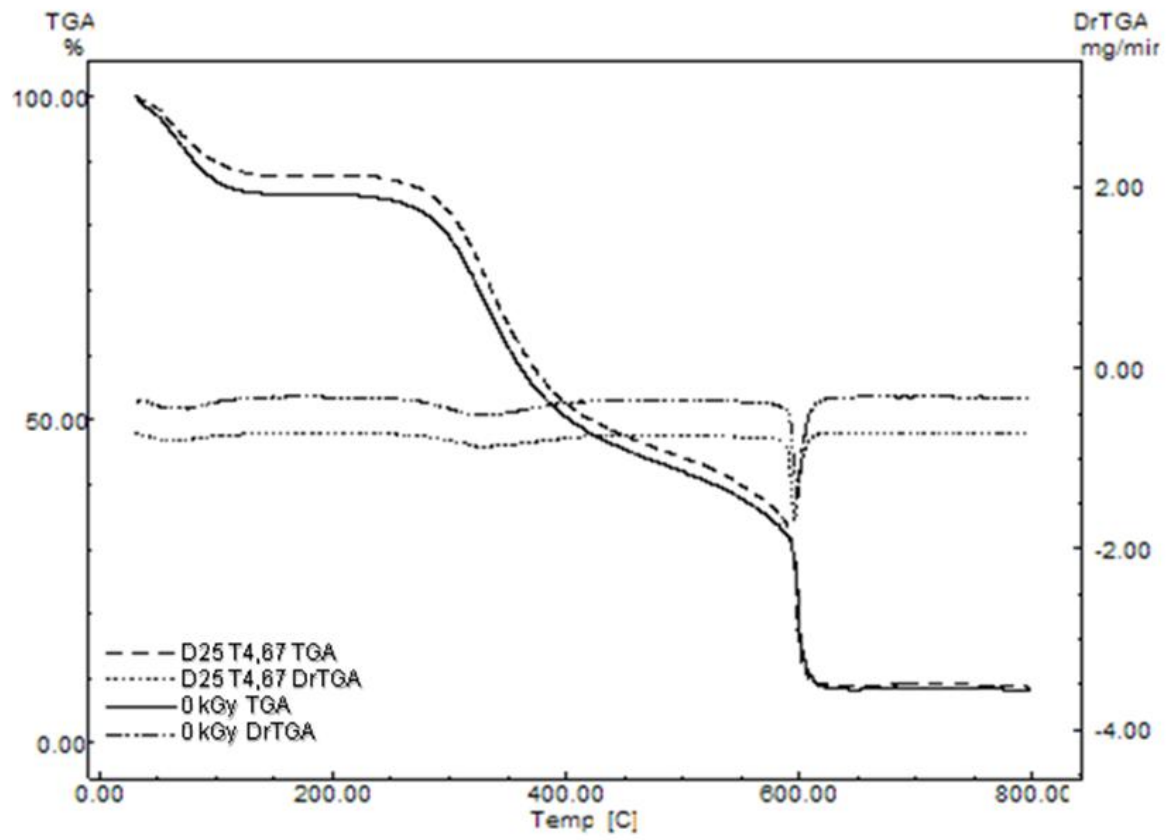

Figura 23. Curvas termogravimétricas e respectivas derivadas das amostras de PB não irradiado e PB irradiado na dose de 25 kGy, taxa de dose de 4,67 kGy/s.

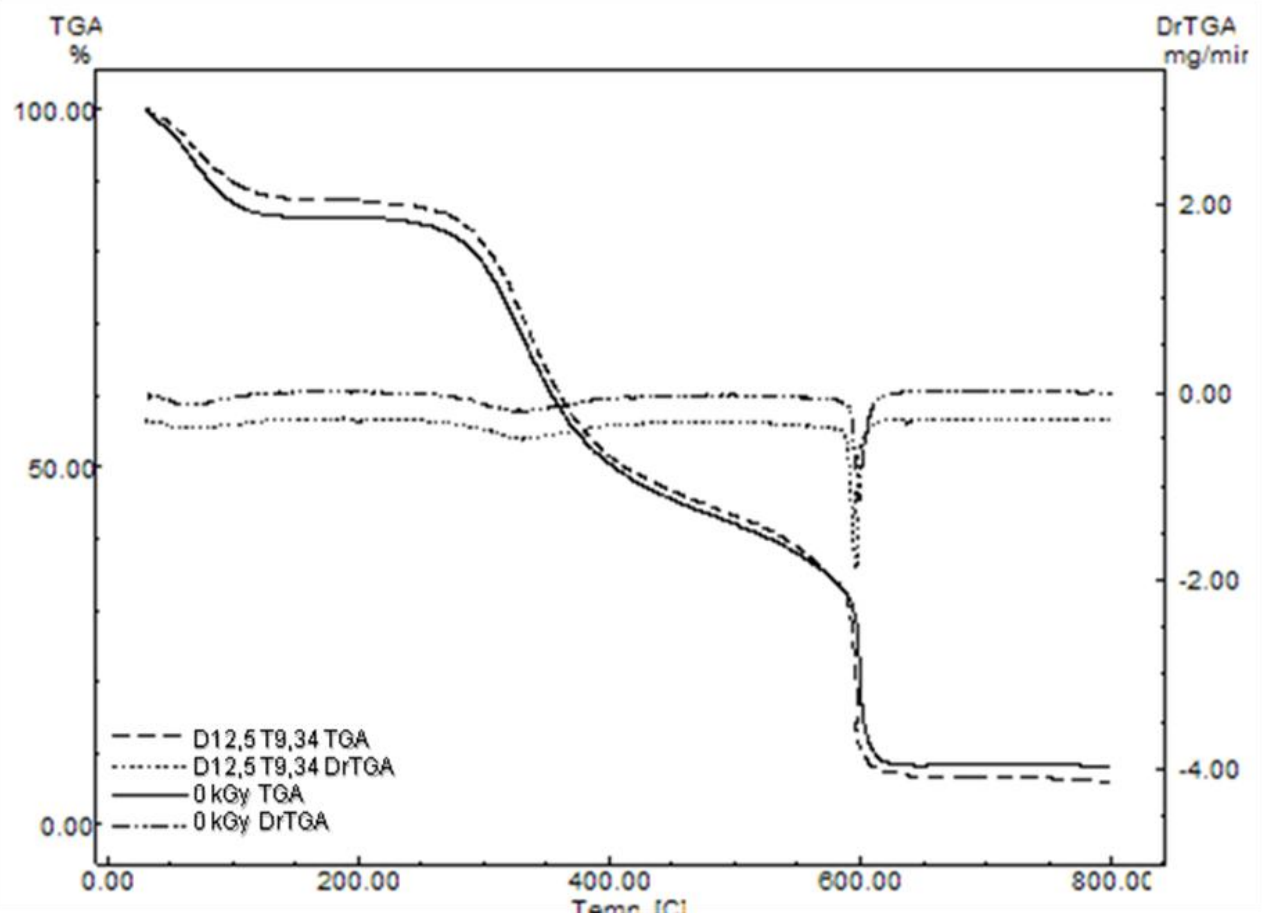

Figura 24. Curvas termogravimétricas e respectivas derivadas das amostras de PB não irradiado e PB irradiado na dose de 12,5 kGy, taxa de dose de 9,34 kGy/s. 


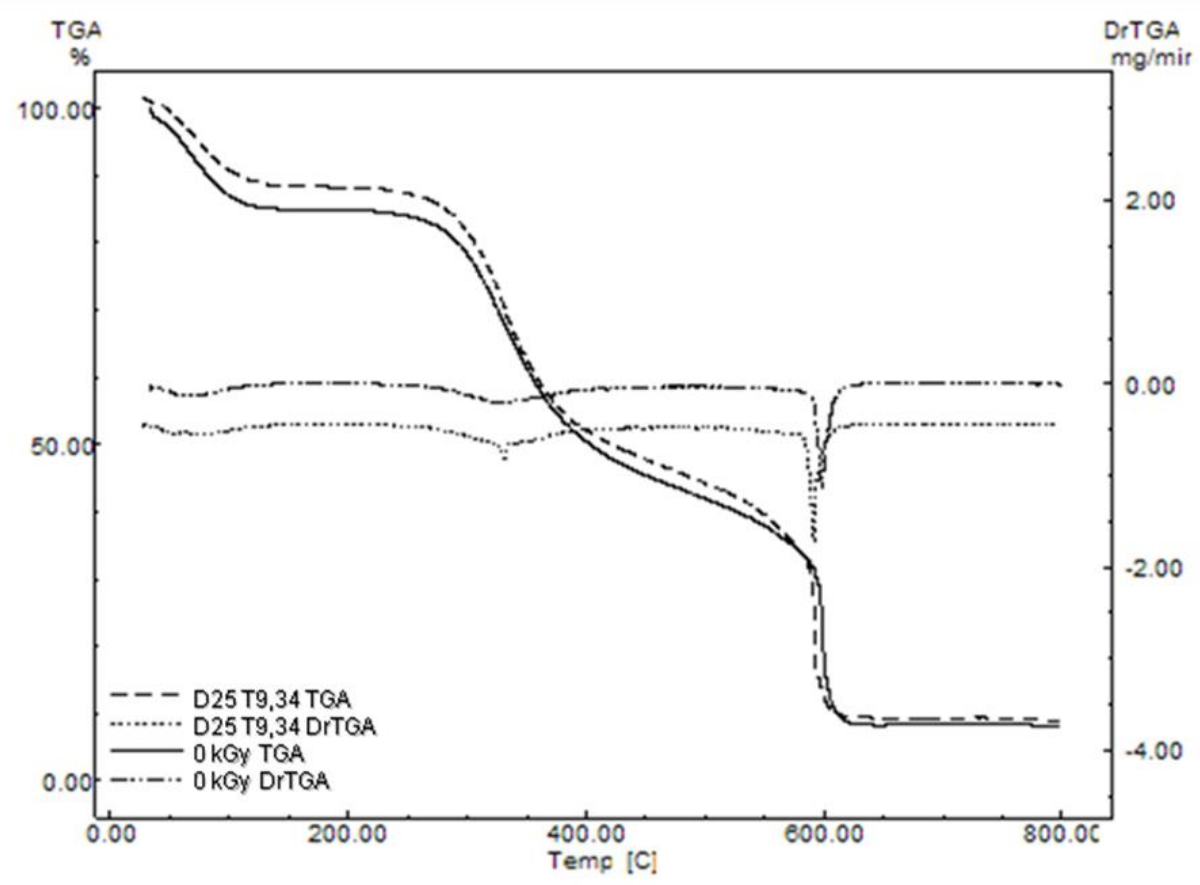

Figura 25. Curvas termogravimétricas e respectivas derivadas das amostras de PB não irradiado e PB irradiado na dose de 25 kGy, taxa de dose de 9,34 kGy/s.

\subsubsection{Determinação da temperatura de encolhimento}

Análises de DSC foram realizadas a fim de verificar se a irradiação na ausência ou na presença de oxigênio altera a temperatura de encolhimento do tecido de PB. A temperatura de encolhimento da matriz reticulada tem sido usada como um guia para a estabilidade in vivo de um implante de colágeno. $A$ temperatura de encolhimento das fibras de colágeno é um evento endotérmico e pode ser relacionada com o grau de reticulação. A temperatura de encolhimento das fibras de colágeno mede a transição das moléculas de colágeno a partir da tripla hélice para uma conformação de estrutura ao acaso. Esta temperatura depende do número de ligações intermoleculares (crosslinks intermoleculares) formadas por meios químicos. Geralmente, quanto maior o número de ligações intermoleculares, maior a temperatura de encolhimento térmico e mais estável o material será in vivo (PARK; BRONZINO, 2003). Outra 
característica que pode ser observada é um aumento da energia envolvida no processo (TATTINI JR. et al., 2007).

Após análise das médias de três curvas por amostra obtidas por DSC, observou-se que a temperatura de todas as amostras foram deslocadas para menos em até $14,41^{\circ} \mathrm{C}$ (Tabela 5). Curiosamente, a energia envolvida no evento aumentou para todas as amostras irradiadas com oxigênio em até $2,4 \mathrm{~J} / \mathrm{g}$. Para as amostras irradiadas sem oxigênio a temperatura de encolhimento diminuiu menos quando comparado com as amostras irradiadas com $\mathrm{O}_{2}$. A energia envolvida no processo $(\Delta \mathrm{H})$ para estas amostras foi bem menor do que para as amostras irradiadas com oxigênio. Entretanto, a partir destes dados não é possível estabelecer alguma relação entre os efeitos causados às amostras e as doses e taxas de dose aplicadas.

Isto pode estar ocorrendo por fatores como a heterogeneidade do tecido, as diferentes espessuras que as amostras apresentam e devido à desuniformidade na dose de irradiação absorvida pelas amostras, uma das desvantagens da irradiação por feixe de elétrons (SUGRANES, 2005). As figuras 26-34 representam as curvas obtidas para cada amostra.

Tabela 5. Temperatura de encolhimento do PB irradiado sob vácuo.

\begin{tabular}{c|cc}
\hline Amostra & Média do Pico $(\circ \mathbf{C})$ & Média $\Delta \mathrm{H}^{*}(\mathbf{J} / \mathbf{g})$ \\
\hline Controle & $60,6 \pm 0,32$ & $4,12 \pm 0,66$ \\
$12,5 \mathrm{kGy}-4,67 \mathrm{kGy} / \mathrm{s} \mathrm{com} \mathrm{O}_{2}$ & $51,79 \pm 0,93$ & $4,96 \pm 0,58$ \\
$25 \mathrm{kGy}-4,67 \mathrm{kGy} / \mathrm{s} \mathrm{com} \mathrm{O}{ }_{2}$ & $46,19 \pm 0,45$ & $6,52 \pm 0,10$ \\
$12,5 \mathrm{kGy}-9,34 \mathrm{kGy} / \mathrm{s} \mathrm{com} \mathrm{O} \mathrm{O}_{2}$ & $51,26 \pm 0,35$ & $4,99 \pm 1,04$ \\
$25 \mathrm{kGy}-9,34 \mathrm{kGy} / \mathrm{s} \mathrm{com} \mathrm{O} \mathrm{O}_{2}$ & $47,69 \pm 1,46$ & $6,52 \pm 0,37$ \\
$12,5 \mathrm{kGy}-4,67 \mathrm{kGy} / \mathrm{s} \mathrm{sem} \mathrm{O} \mathrm{O}_{2}$ & $52,3 \pm 0,92$ & $2,07 \pm 0,14$ \\
$25 \mathrm{kGy}-4,67 \mathrm{kGy} / \mathrm{s} \mathrm{sem} \mathrm{O}_{2}$ & $49,15 \pm 0,76$ & $2,29 \pm 0,73$ \\
$12,5 \mathrm{kGy}-9,34 \mathrm{kGy} / \mathrm{s} \mathrm{sem} \mathrm{O}_{2}$ & $54,51 \pm 0,62$ & $2,88 \pm 1,05$ \\
$25 \mathrm{kGy}-9,34 \mathrm{kGy} / \mathrm{s} \mathrm{sem} \mathrm{O}_{2}$ & $48,19 \pm 1,11$ & $0,98 \pm 0,39$ \\
\hline
\end{tabular}

${ }^{*} \Delta \mathrm{H}$ - energia de entalpia. $(\mathrm{n}=4)$ 


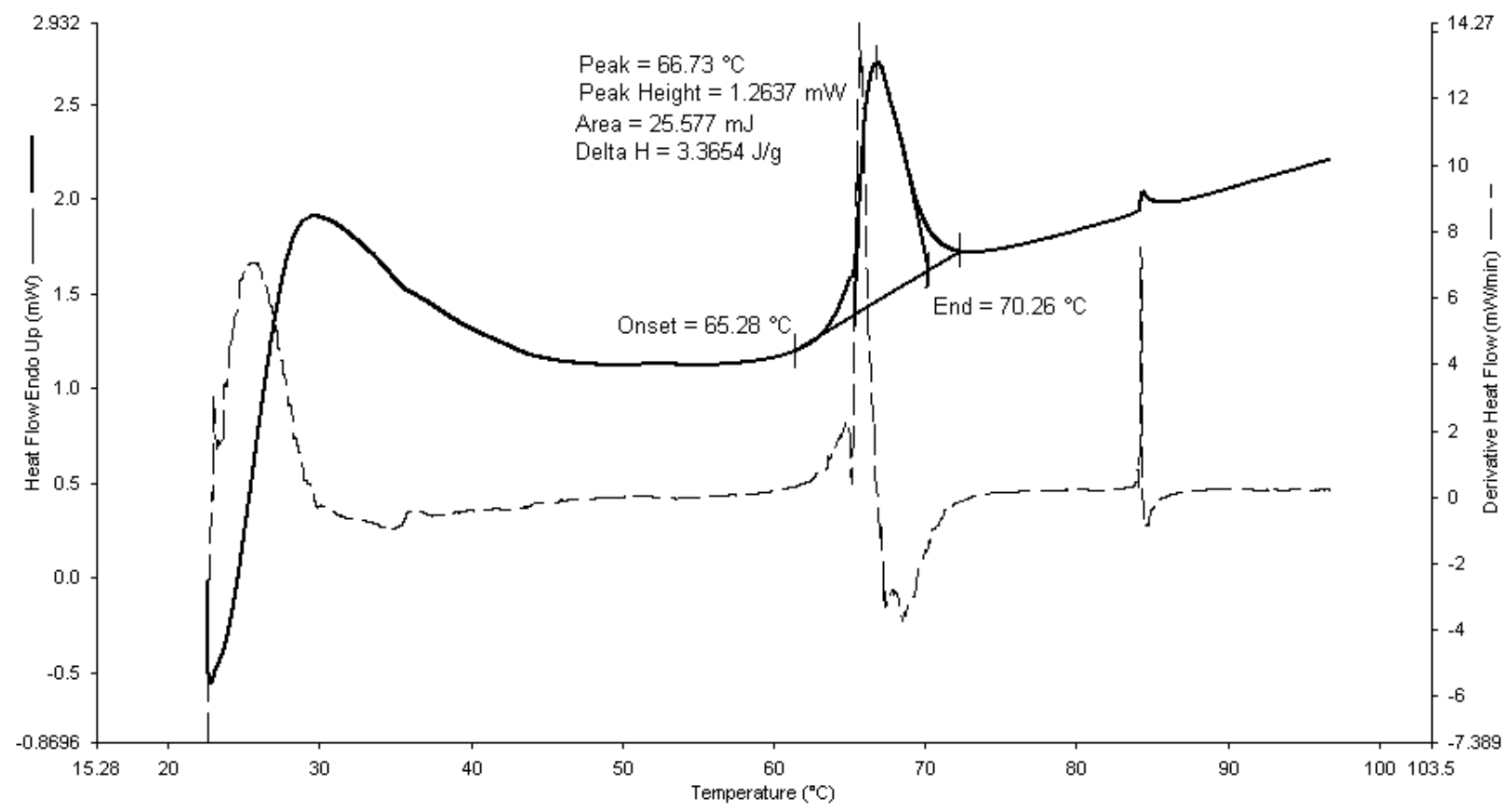

Figura 26. Curva de DSC do PB liofilizado e não irradiado. A linha pontilhada representa sua derivada.

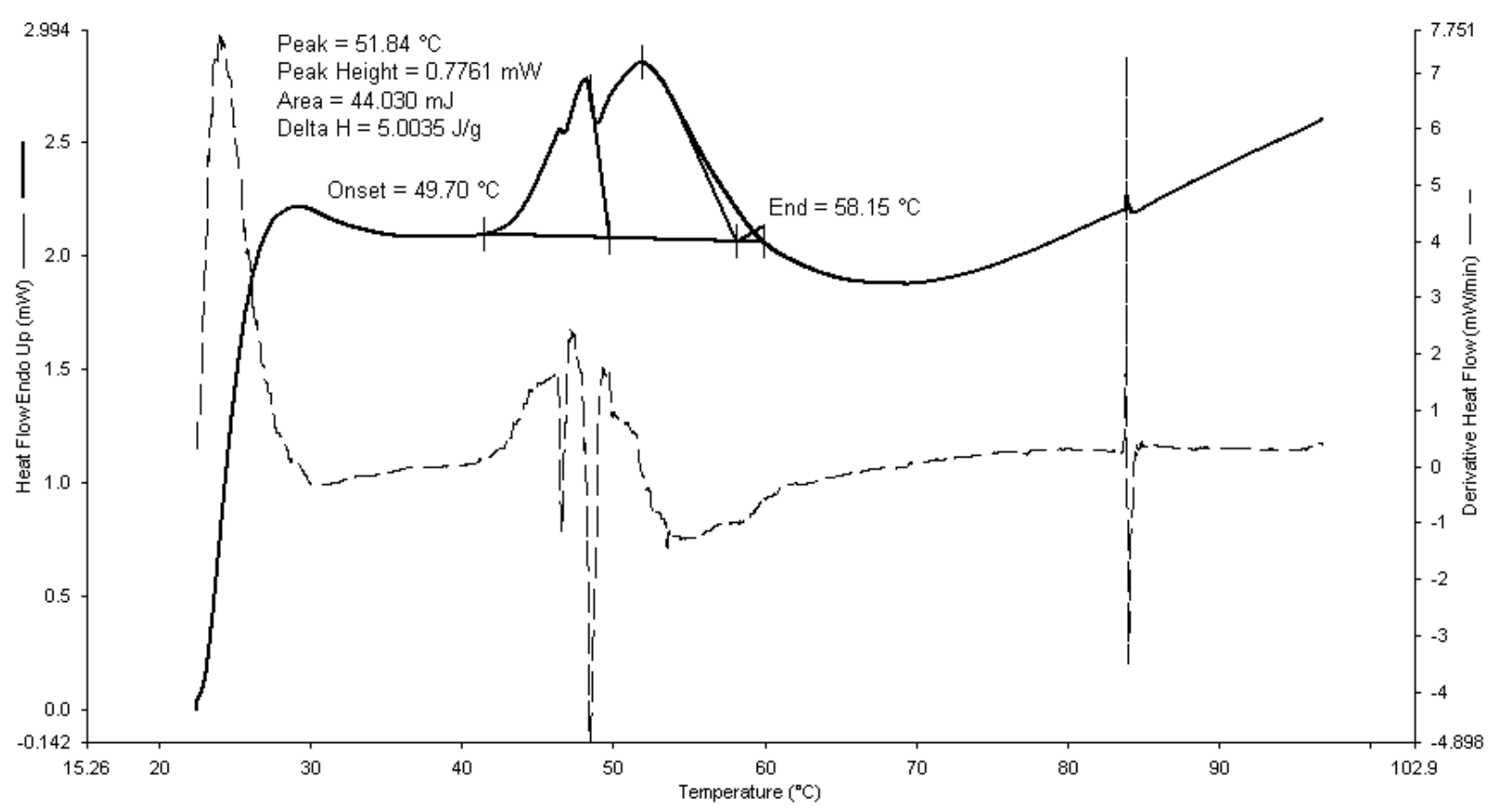

Figura 27. Curva de DSC do PB liofilizado e irradiado na dose de $12,5 \mathrm{kGy}$, taxa de dose de 4,67 kGy/s com oxigênio. A linha pontilhada representa sua derivada. 


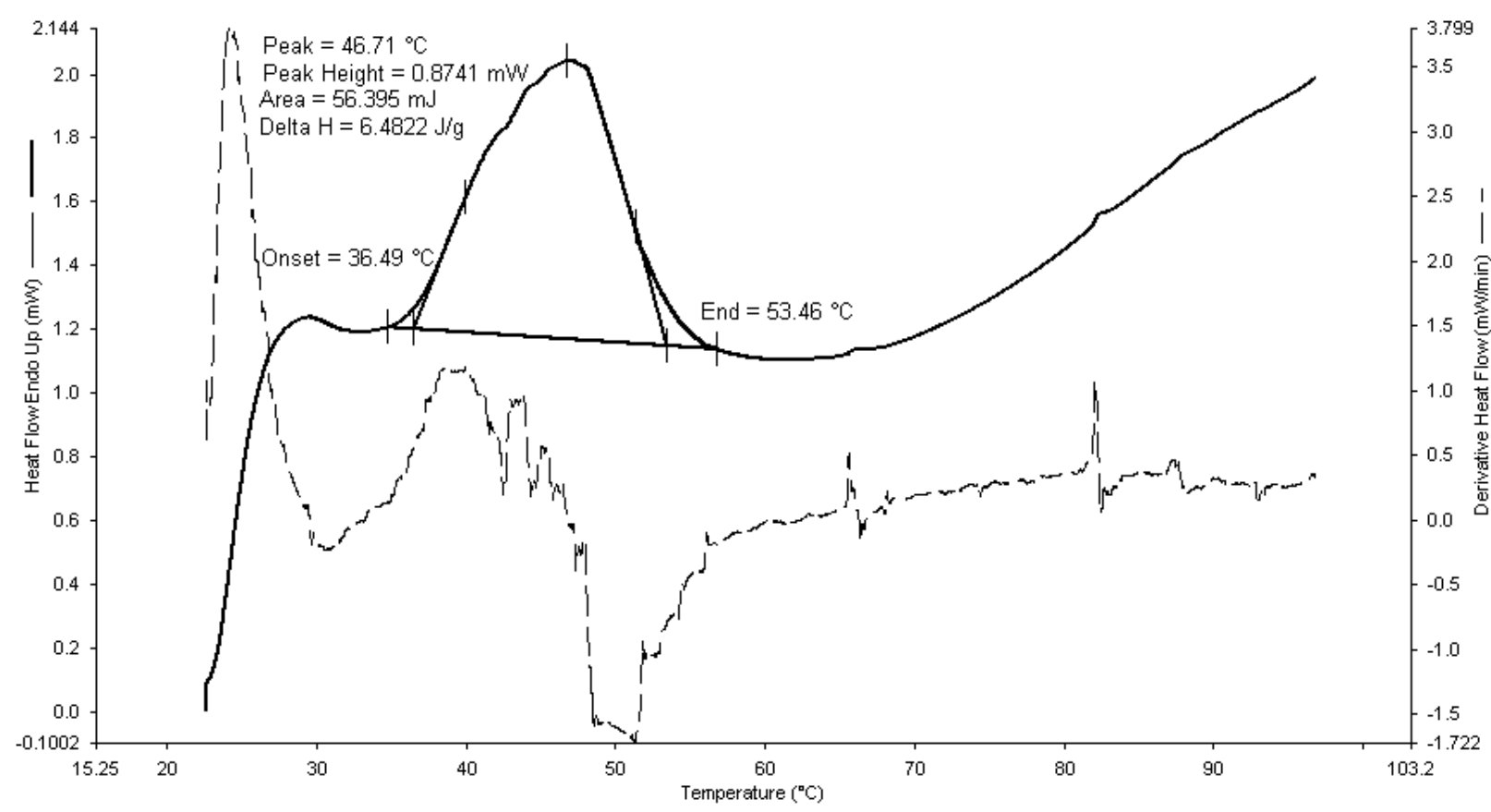

Figura 28. Curva de DSC do PB liofilizado e irradiado na dose de $25 \mathrm{kGy}$, taxa de dose de 4,67 kGy/s com oxigênio. A linha pontilhada representa sua derivada.

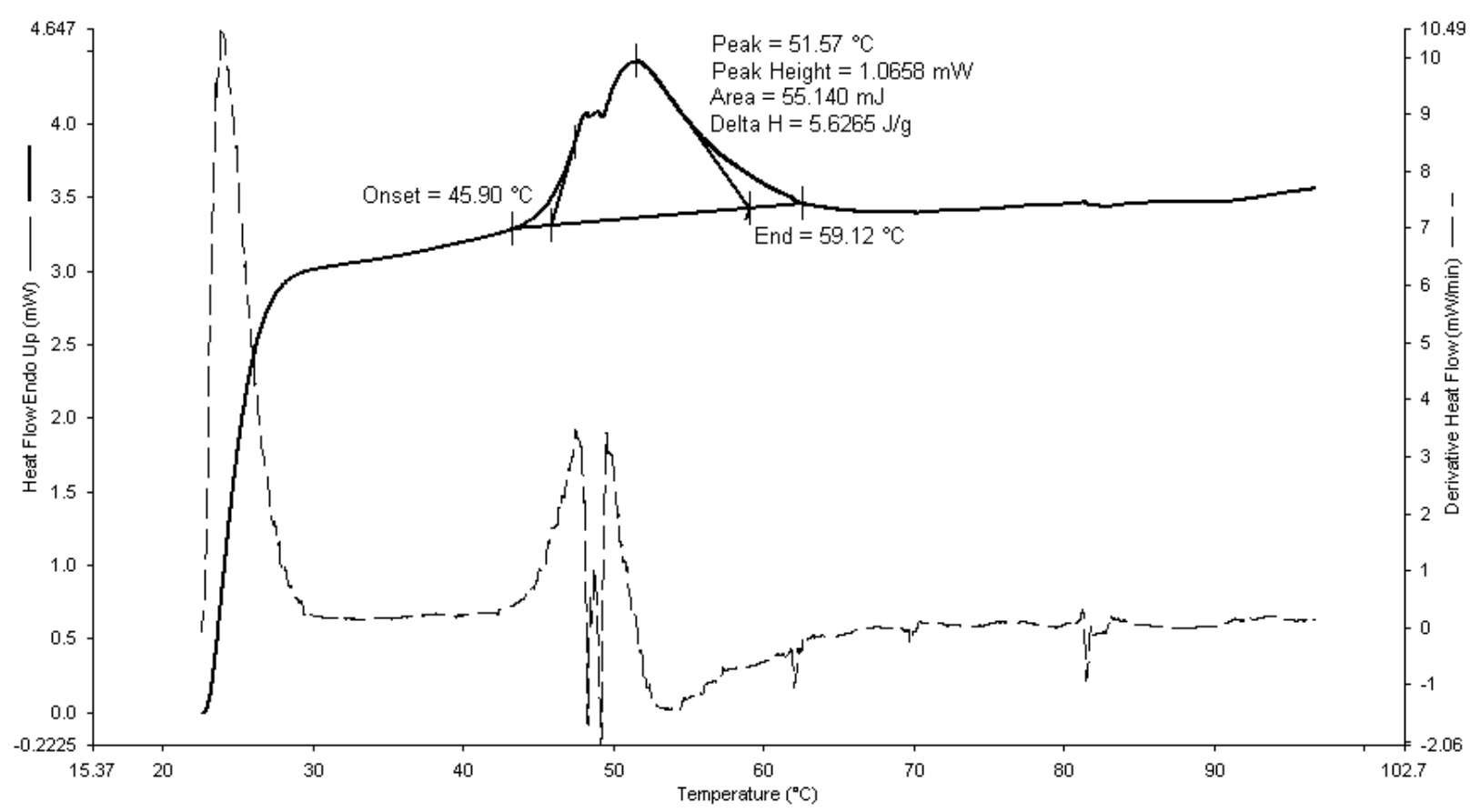

Figura 29. Curva de DSC do PB liofilizado e irradiado na dose de $12,5 \mathrm{kGy}$, taxa de dose de 9,34 kGy/s com oxigênio. A linha pontilhada representa sua derivada. 


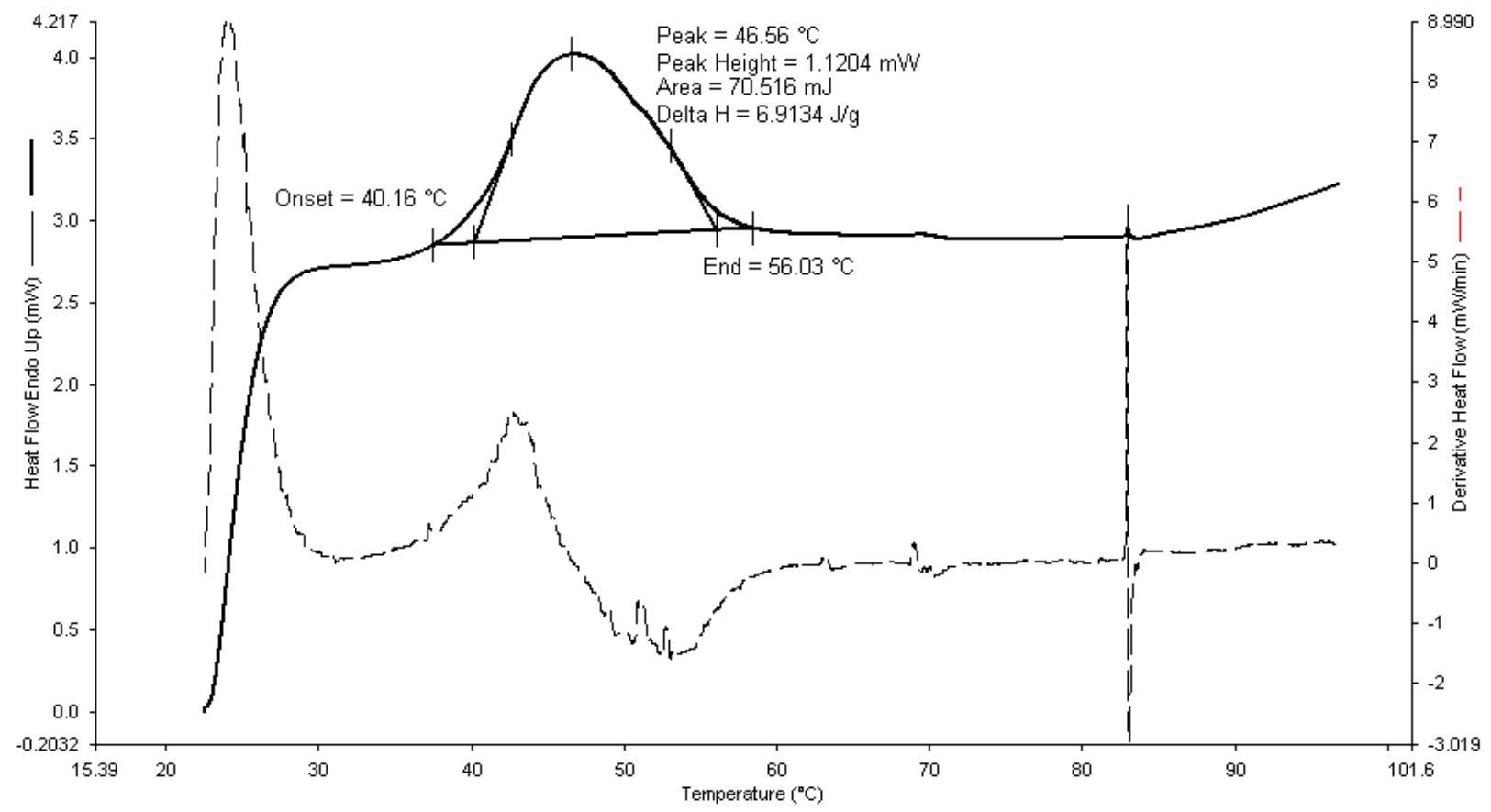

Figura 30. Curva de DSC do PB liofilizado e irradiado na dose de 25 kGy, taxa de dose de 9,34 kGy/s com oxigênio. A linha pontilhada representa sua derivada.

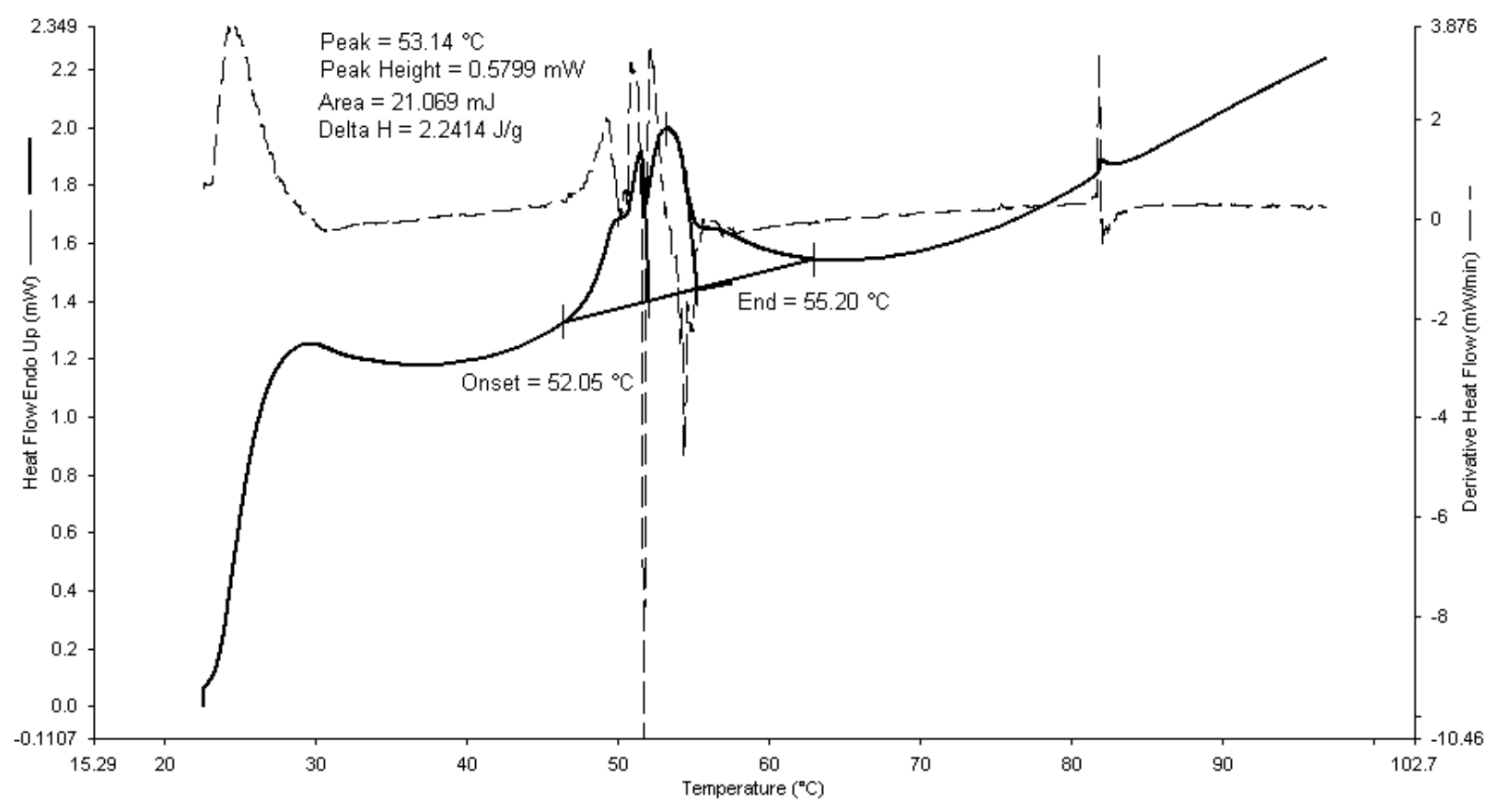

Figura 31. Curva de DSC do PB liofilizado e irradiado na dose de 12,5 kGy, taxa de dose de 4,67 kGy/s sem oxigênio. A linha pontilhada representa sua derivada. 


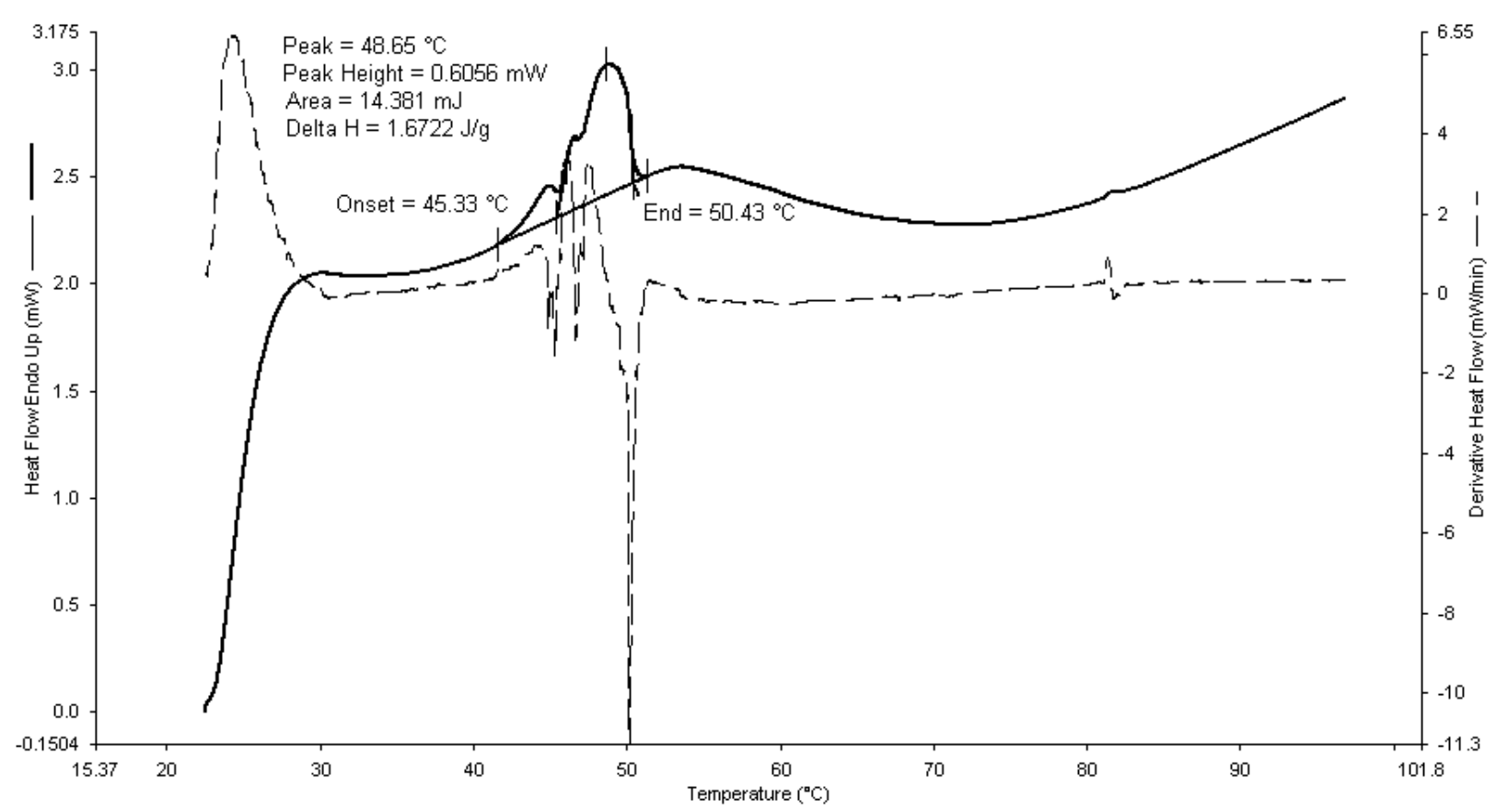

Figura 32. Curva de DSC do PB liofilizado e irradiado na dose de $25 \mathrm{kGy}$, taxa de dose de 4,67 kGy/s sem oxigênio. A linha pontilhada representa sua derivada.

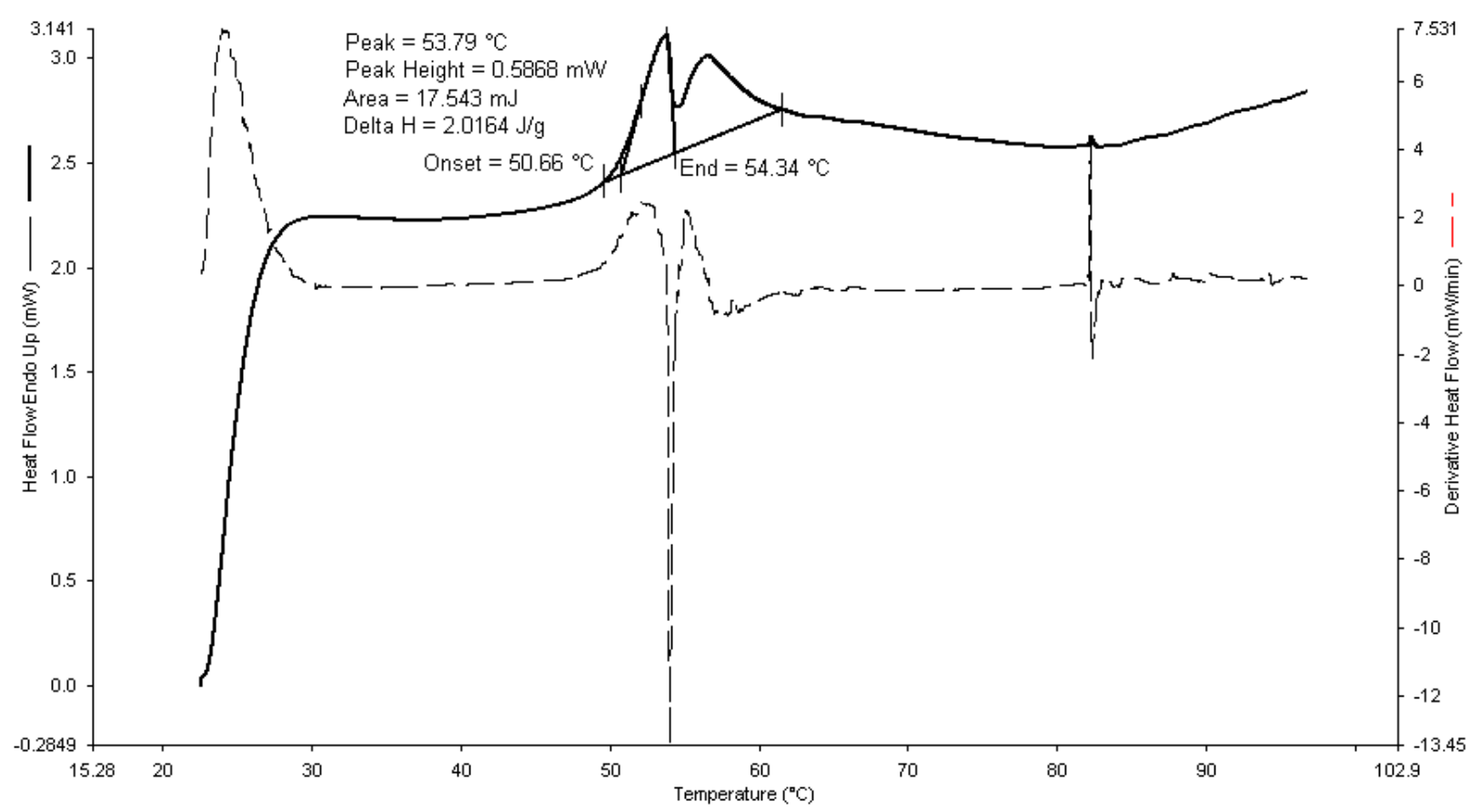

Figura 33. Curva de DSC do PB liofilizado e irradiado na dose de 12,5 kGy, taxa de dose de 9,34 kGy/s sem oxigênio. A linha pontilhada representa sua derivada. 


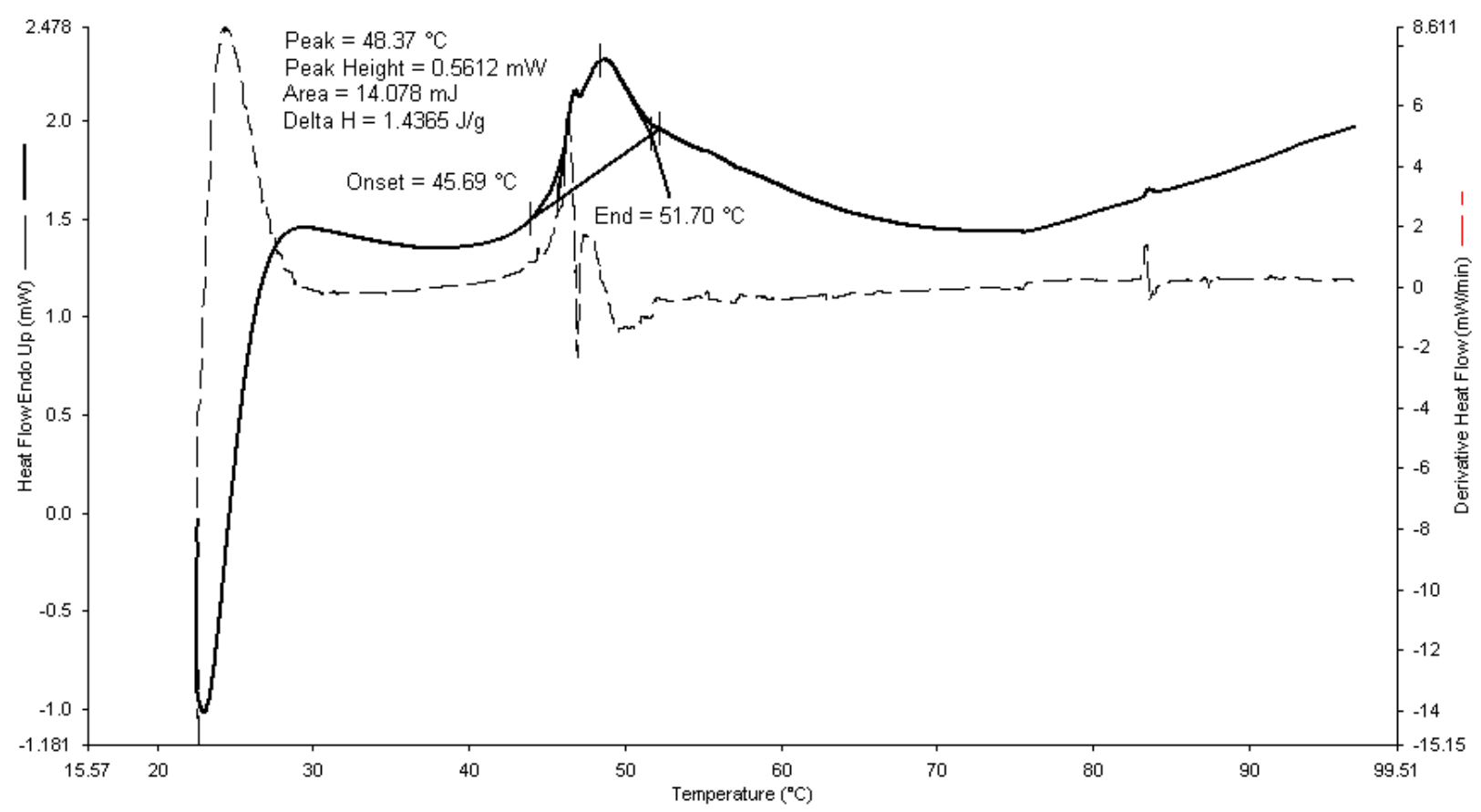

Figura 34. Curva de DSC do PB liofilizado e irradiado na dose de 25 kGy, taxa de dose de 9,34 kGy/s sem oxigênio. A linha pontilhada representa sua derivada.

\subsubsection{Teste de tração}

A fim de verificar se as alterações provocadas pela irradiação na presença e ausência do oxigênio provocam aumento ou diminuição das propriedades mecânicas do material o teste de tração foi realizado escolhendose dois parâmetros diferentes de acordo com os gráficos de intumescimento. De acordo com o teste de intumescimento das amostras irradiadas na ausência de oxigênio (Figura 16) a dose de 25 kGy na taxa de dose de 4,67 kGy/s parece ser a responsável pela maior reticulação, fazendo com que esta amostra absorvesse menos água. A fim de comparar os efeitos da radiólise na presença do oxigênio o teste de tração também foi realizado com as amostras utilizando-se os mesmos parâmetros (Dose de 25 kGy, taxa de 4,67 kGy/s), porém na presença de oxigênio (Tabela 6). 
Tabela 6. Dados obtidos pelo teste de tração das amostras irradiadas na presença e ausência de oxigênio.

\begin{tabular}{c|ccc}
\hline Amostra & $\mathbf{E}^{*}(\mathbf{M P a})$ & $\mathbf{R}^{2}$ & $\boldsymbol{\sigma}_{\text {rup }}{ }^{* *}(\mathbf{M P a})$ \\
\hline PB irradiado com $\mathrm{O}_{2}$ & $68,74 \pm 37,75$ & 0,98 & $12,35 \pm 6,96$ \\
PB irradiado sem $\mathrm{O}_{2}$ & $61,09 \pm 36,48$ & 0,97 & $10,59 \pm 4,71$ \\
PB controle & $108,56 \pm 40,69$ & 0,99 & $12,26 \pm 5,19$ \\
\hline
\end{tabular}

${ }^{*} \mathrm{E}:$ módulo de Young, ${ }^{* *} \sigma_{\text {rup: }}$ tensão de ruptura. $(\mathrm{n}=50)$

De acordo com os resultados obtidos pelo teste de tração ambos os parâmetros de irradiação (ausência ou presença de oxigênio) diminuem consideravelmente o módulo de Young, ou seja, a elasticidade do tecido de PB, quando comparados com o PB somente liofilizado. O PB irradiado na ausência de oxigênio apresentou um valor menor de elasticidade (61,09 MPa) quando comparado com o irradiado na presença de $\mathrm{O}_{2}$. Este resultado é contraditório ao resultado esperado, já que supúnhamos que a reticulação do tecido de PB incrementaria as propriedades biomecânicas do tecido. Isto pode ter ocorrido, pois apesar de reticulado o tecido pode ter ficado mais rígido ao invés de elástico. Analisando-se estatisticamente os dados pode-se concluir que entre as amostras irradiadas (com e sem $\left.\mathrm{O}_{2}\right)$ não há diferença significativa $(p>0,05)$ para os módulos de elasticidade obtidos. Entre as amostras irradiadas (com e sem $\left.\mathrm{O}_{2}\right)$ e PB controle há diferença significativa $(p<0,05)$ para os módulos de elasticidade obtidos, sendo o E obtido para o PB controle significativamente maior do que o valor de E para as amostras irradiadas. Também é possível observar que quando irradiado na ausência de oxigênio a tensão de ruptura também é diminuída, enquanto que na presença de oxigênio a $\sigma_{\text {rup }}$ parece ser mantida, em relação ao PB somente liofilizado.

Hafeez et al. (2005) demonstraram que a irradiação gama causou efeito significativo sobre as propriedades biomecânicas do pericárdio bovino liofilizado. Os efeitos de enfraquecimento nas propriedades biomecânicas de do PB liofilizado podem ter ocorrido devido ao efeito nocivo dos raios gama nas moléculas dos feixes de colágeno. 


\subsubsection{Microscopia eletrônica de transmissão (MET)}

Para um estudo mais detalhado dos efeitos da irradiação nas fibras de colágeno presente no tecido de pericárdio bovino, análises histológicas e por micrografia eletrônica de transmissão foram realizadas. Para a realização destas análises foram escolhidas as amostras irradiadas nos mesmos parâmetros utilizados para o teste de tração (Dose 25 kGy, taxa de dose de 4,67 kGy/s) na ausência e presença de oxigênio e também a amostra controle (0 kGy).

De acordo com as lâminas preparadas com corte semifino (aproximadamente $400 \mathrm{~nm}$ ) coradas com azul de toluidina (Figura 35), pode-se observar a estrutura organizada após a liofilização do tecido controle (A1). Na figura 35-B1 é possível verificar que a degradação é fenômeno predominante nas fibras de colágeno quando a irradiação ocorre na presença de oxigênio. Já na figura $35-C 1$, onde o tecido foi irradiado na ausência de oxigênio, é possível observar que o tecido encontra-se mais compactado devido à reticulação.

Após análise das imagens obtidas por MET é possível verificar na figura 35-A2 que as fibras de colágeno orientadas longitudinalmente apresentam as bandas de colágeno características encontradas em fibras normais e as fibras normalmente orientadas no sentido transversal. Porém ao observarmos cuidadosamente a imagem referente ao controle foi possível verificar pontos onde as fibras parecem estar rompidas (setas brancas), indicando que a liofilização utilizada até então rompe as fibras de colágeno. Na figura 35-B2 verifica-se que a estrutura do colágeno parece estar bastante desorganizada e que também houve uma diminuição no contraste das bandas características do colágeno, indicando a degradação do colágeno (BAILEY; THOMAS, 1964). Analisando a figura 35-C2, verifica-se que a estrutura do colágeno apresentase mais organizada, sendo possível verificar as bandas características do colágeno, mas também algumas das fibras rompidas (setas brancas). A estrutura apresenta-se também mais compactada e alguns pontos indicam que houve reticulação do tecido (setas pretas). 

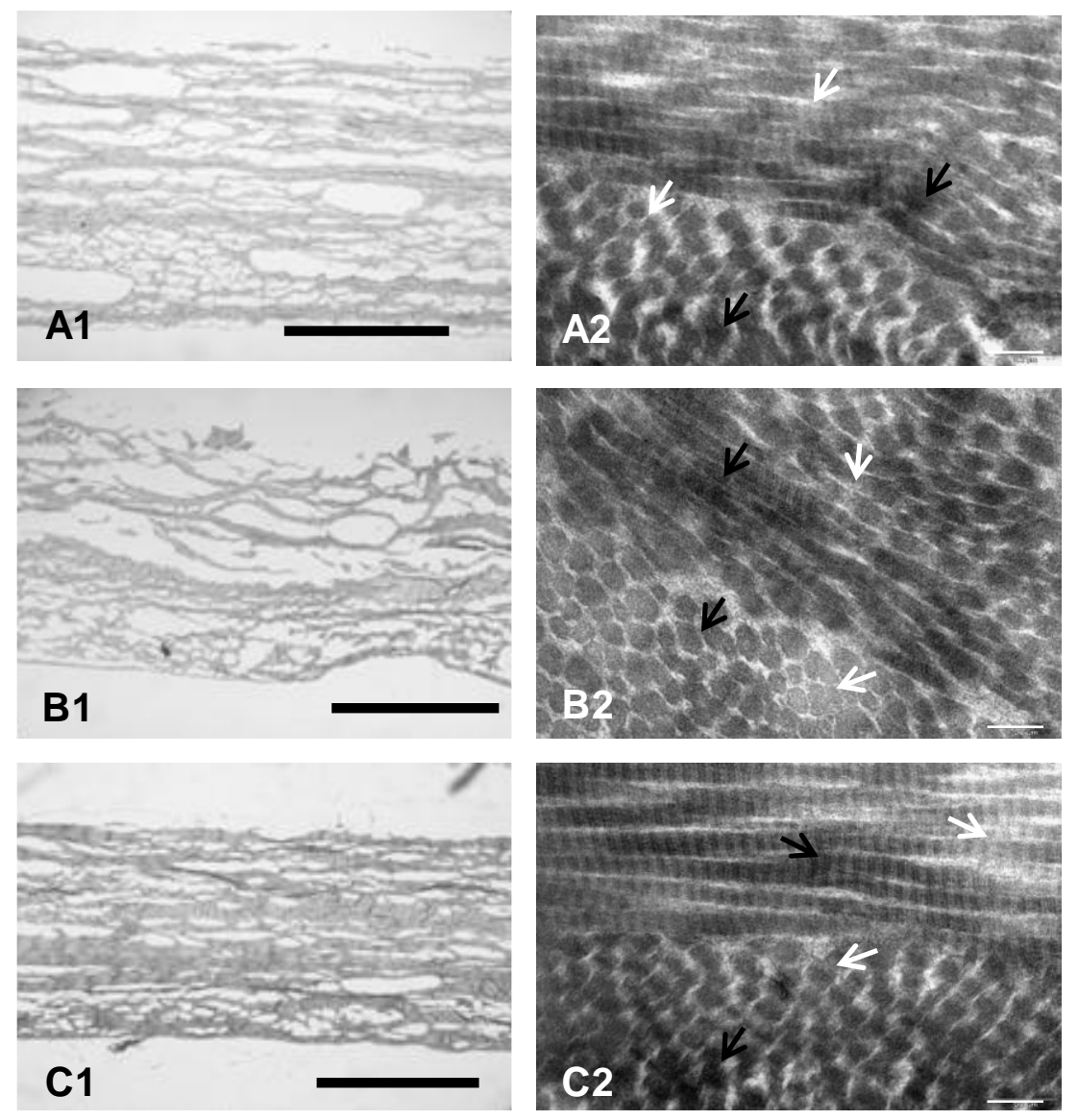

Figura 35. Lâminas do corte semifino, coradas com azul de toluidina - lado esquerdo. Micrografias obtidas por microscopia eletrônica de transmissão lado direito. A1 e A2 - controle (0 kGy); B1 e B2 - tecido irradiado na presença de $\mathrm{O}_{2}$ (25 kGy, 4,67 kGy/s); $\mathrm{C} 1$ eC2 - tecido irradiado na ausência de $\mathrm{O}_{2}$ (25 kGy, 4,67 kGy/s). As setas brancas indicam degradação do tecido. As setas pretas indicam reticulação.

\subsubsection{Teste de biofuncionalidade in vitro}

O teste de biofuncionalidade foi realizado para verificar se os tecidos modificados promovem ou inibem a adesão e proliferação celular. Para tanto foram escolhidas três amostras irradiadas de acordo com todos os testes discutidos anteriormente. As amostras irradiadas na dose de $25 \mathrm{kGy}$ na taxa de dose de 4,67 kGy/s na presença e na ausência de oxigênio foram escolhidas. 
A Figura 36-A mostra o tecido de PB preservado em glicerol e depois liofilizado, que foi utilizado como controle. Os círculos mostram algumas das células presentes no tecido, indicando que o tecido é um ambiente favorável à adesão e proliferação das células endoteliais, e ainda que estas tendem a se organizar de forma alinhada

$488 \mathrm{~nm}$ e $514 \mathrm{~nm}$
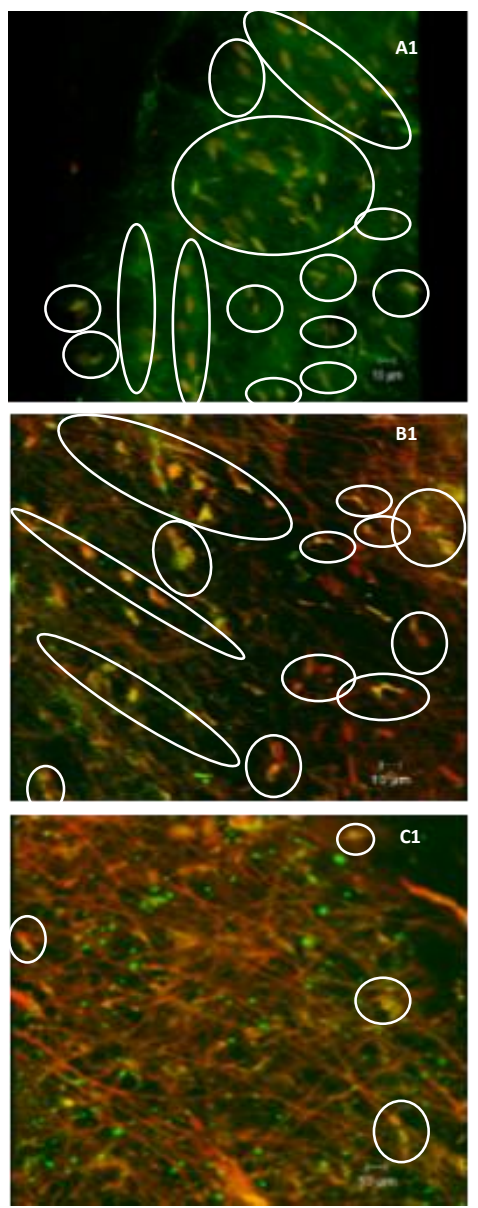

$488 \mathrm{~nm}$
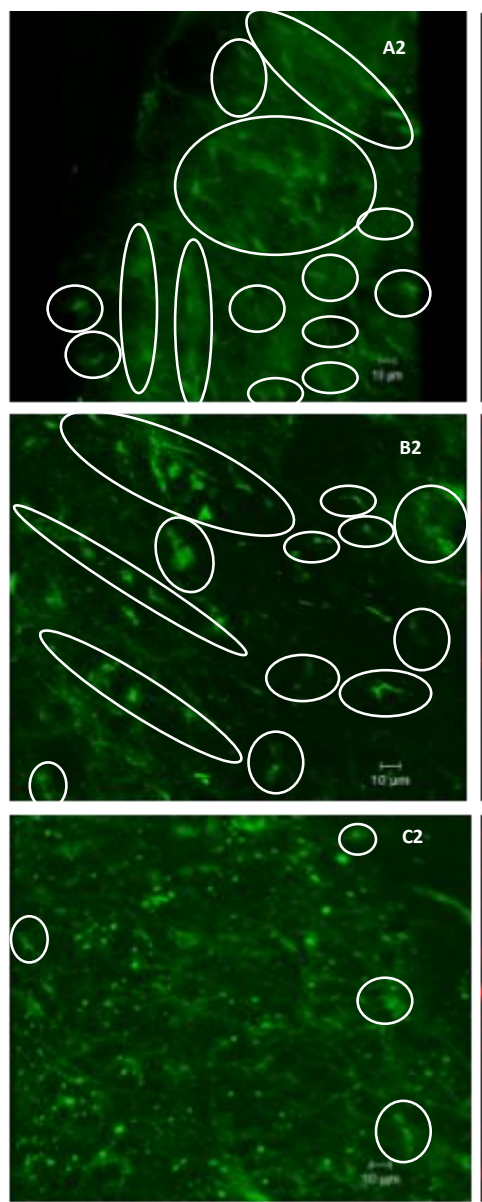

$514 \mathrm{~nm}$
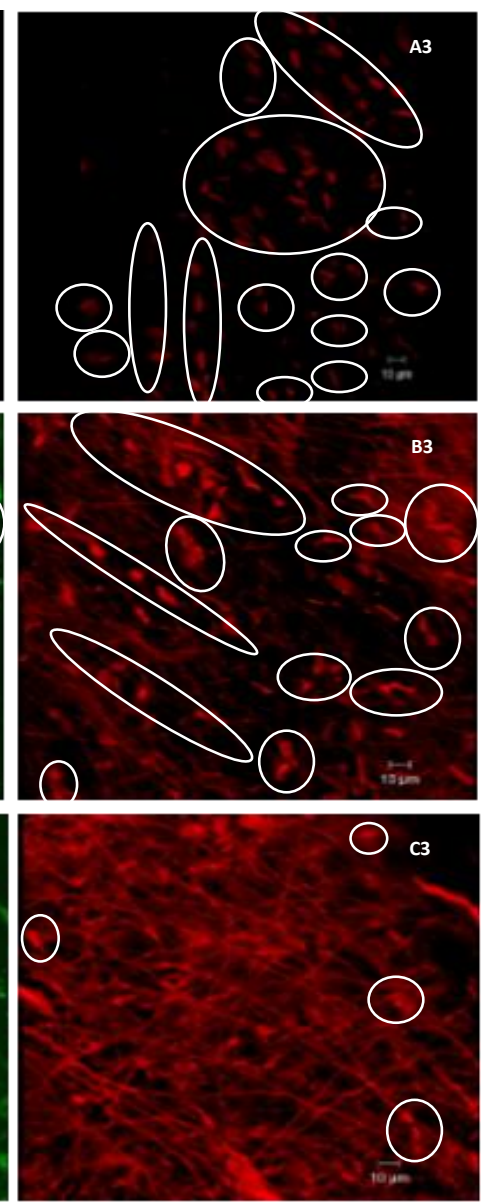

Figura 36. Imagens do PB não tratado $(A)$, irradiado sem $\mathrm{O}_{2}(\mathrm{~B})$ e $c o m \mathrm{O}_{2}(\mathrm{C})$ após o cultivo de células endoteliais (HUVEC) in vitro. Imagens obtidas por microscopia confocal utilizando-se o comprimento de onda em $488 \mathrm{~nm}$ e $514 \mathrm{~nm}$. Os círculos mostram os pontos onde estão as células funcionais. Todas as barras de escala representam $10 \mu \mathrm{m}$. 
A porção corada de verde são as fibras de colágeno do tecido, as quais apresentam autofluorescência em $488 \mathrm{~nm}$. Os pontos verdes em $488 \mathrm{~nm}$ são resultantes da excitação do anticorpo fluoresceína, que nos permite identificar a atividade funcional das células endoteliais. Os pontos em vermelho em $514 \mathrm{~nm}$ são os núcleos das células aderidas no tecido, os quais foram corados com brometo de etídio.

A Figura 36-B mostra as imagens tridimensionais das amostras irradiadas na dose de 25 kGy (taxa de 4,67 kGy/s) sem oxigênio. Como podese observar, as fibras de colágeno aparecem em vermelho, o que indica que estas sofreram alteração de sua estrutura original após a irradiação e por isso são absorvidas em outro comprimento de onda.

$\mathrm{Na}$ amostra que foi irradiada com oxigênio (Figura 36-C) pode-se observar que as fibras estão mais frouxas, corroborando com o estudo de intumescimento, em que estas amostras intumesciam mais em relação àquelas irradiadas na ausência de oxigênio. Também é possível concluir que a irradiação na ausência de oxigênio favorece a reticulação das fibras colagênicas, orientando-as. Em ambas as amostras a adesão e o crescimento celular foram promovidos, entretanto na amostra irradiada sem $\mathrm{O}_{2}$ e possível observar com maior frequência o número de células aderidas e viáveis se comparado com a amostra irradiada na presença de ar.

A partir destes resultados podemos concluir que quando a irradiação por feixe de elétrons é utilizada para irradiar o tecido de PB, mesmo utilizando-se doses relativamente baixas (na faixa de 6,25 a 31,25 kGy), já se mostra suficiente para alterar o tecido. Quando a irradiação foi feita na presença de oxigênio foi possível observar que o tecido sofre preferencialmente cisão das cadeias de colágeno, entretanto em paralelo é possível que ligações cruzadas ocorram entre as moléculas. Já na ausência de oxigênio, utilizando-se os mesmos parâmetros de irradiação, foi possível notar que o tecido sofre preferencialmente reticulação. Também é possível concluir que as taxas de dose aplicadas durante a irradiação é um parâmetro importante, pois sugere que a menor taxa aplicada favorece maior taxa de reticulação. Ainda, é 
possível concluir as alterações estruturais nas amostras irradiadas de PB não foram suficientes para serem detectadas utilizando-se a termogravimetria (TGA). As análises de temperatura de encolhimento (DSC) sugerem que o material irradiado possui menor estabilidade in vivo. Após a execução do teste de biofuncionalidade é possível concluir que as alterações causadas pela irradiação no tecido de PB não inibem a adesão e proliferação de células endoteliais no tecido. 


\subsection{Modificações do tecido de PB com soluções de quitosana e fibroína de seda}

\subsubsection{Determinação dos parâmetros de modificação com as soluções de $Q$, SF e suas misturas utilizando-se o teste de intumescimento}

Após a obtenção das soluções, amostras de PB liofilizadas foram intumescidas com as diferentes soluções para a determinação dos parâmetros de impregnação (ver Seção 4.14). A cinética de intumescimento para todas as soluções foi realizada em sala com temperatura controlada, $23 \pm 2^{\circ} \mathrm{C}$.

Para o intumescimento das soluções de quitosana dissolvidas em solução aquosa de ácido acético (1\%) duas soluções foram preparadas, uma na concentração de $1 \%$ e a outra a $2 \%$. Concentrações maiores que estas tornam a solução de quitosana muito viscosa, o que afetaria a impregnação do tecido de pericárdio bovino. O intumescimento do PB em solução aquosa de ácido acético a 1\% também foi realizado. Como é possível verificar no gráfico (Figura 37), o intumescimento com a solução de quitosana a $1 \%$ não tende à estabilização, apresentando um comportamento crescente de absorção da solução. Isto pode estar ocorrendo, pois o ácido presente na solução tende a degradar o colágeno permitindo que o tecido absorva cada vez maiores quantidades de solução. Este comportamento, porém com maior agressividade, pode ser observada quando o PB é intumescido em solução aquosa de ácido acético a 1\%, na ausência da quitosana. Entretanto este comportamento não é observado quando a concentração de quitosana é maior (2\%). Apesar de esta solução apresentar-se mais viscosa e apresentar menor grau de intumescimento do que a primeira, ela parece "proteger" a quitosana sobre a degradação exercida pelo ácido acético. Portanto, as modificações com solução de quitosana em solução aquosa de ácido acético (1\%) devem ser realizadas preferencialmente com a solução na concentração maior (2\%), a fim de preservar a estrutura do colágeno presente no PB. Para que a absorção seja maximizada a solução deverá estar em contato com o tecido liofilizado por um período de aproximadamente 6 horas. 
O intumescimento com a quitosana modificada ( $\mathrm{N}$-succinil-quitosana) foi realizado com a solução na concentração de 1\%. Concentrações maiores que esta se apresentam muito viscosas, o que prejudicaria a absorção da solução para dentro do tecido de PB. Como é possível observar no gráfico de intumescimento (Figura 37), a estabilização da absorção de quitosana modificada ocorre próxima das 7 h30 do teste. Também é possível notar que a $\mathrm{N}$-succinil-quitosana possui um grau de intumescimento menor em relação à quitosana comum, apesar de apresentar uma maior massa molecular. Isto pode ter ocorrido, pois a solução de quitosana modificada a 1\% apresenta maior viscosidade que a quitosana comum, na mesma concentração. Esta característica pode fazer com que menores quantidades de $\mathrm{N}$-succinilquitosana sejam levadas para dentro do tecido. Para que a absorção seja maximizada a solução deverá estar em contato com o tecido liofilizado por um período entre 6 e 7 horas. A suspensão de fibroína de seda a $2 \%$ apresenta um comportamento e um grau de intumescimento muito semelhante ao da quitosana modificada. Da mesma maneira, para uma boa impregnação da fibroína ao tecido de PB a suspensão deverá estar em contato com o tecido liofilizado por um período entre 6 e 7 horas. Já a mistura das soluções de quitosana e fibroína de seda, ambas a $2 \%$, na proporção de 1:1, parece estabilizar somente por volta das 24 horas.

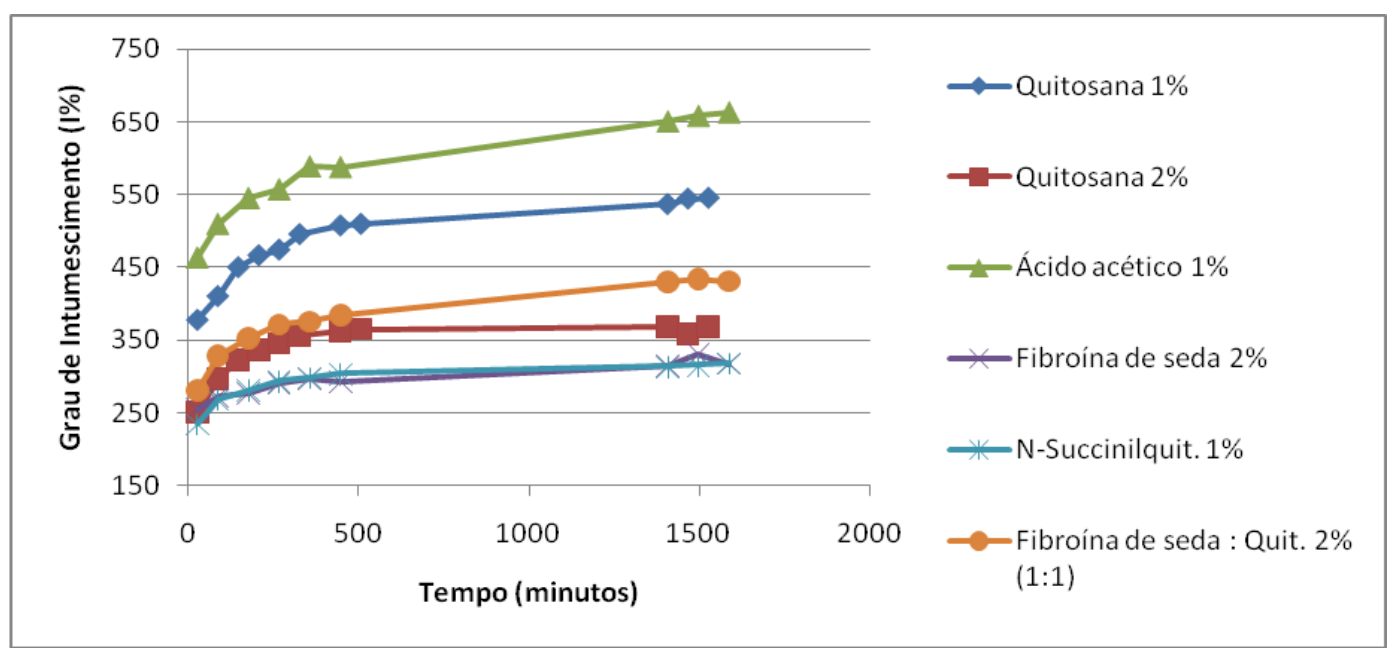

Figura 37. Cinética de intumescimento do PB liofilizado em soluções de quitosana e fibroína de seda. 


\subsubsection{Determinação da temperatura de colapso das soluçoes de $Q$, SF e suas misturas}

Para determinar a temperatura de liofilização das diferentes soluções após serem impregnadas ao tecido de PB, analises para determinação da temperatura de colapso das soluções foram realizadas. Para tanto, utilizou-se a microscopia óptica acoplada a um módulo de liofilização (ver Seção 4.15). A temperatura de colapso é um parâmetro importante que deve ser levado em consideração durante o processo de liofilização. Se o produto é liofilizado em temperatura acima à temperatura de colapso, ocorrem danos em sua estrutura, comprometendo sua estabilidade e em alguns casos sua atividade. Portanto conhecendo-se da temperatura de colapso é possivel determinar uma faixa de temperatura segura de liofilização de um determinado produto.

A Tabela 7 mostra os valores referentes a temperatura de cristalização, temperatura de colapso ou microcolapso e a temperatura segura sugerida para a liofilização.

Tabela 7. Resultados obtidos pela microscopia óptica acoplada a um módulo de liofilização.

\begin{tabular}{c|ccc}
\hline Material & $\begin{array}{c}\text { Temperatura } \\
\text { de } \\
\text { Criatalização } \\
\left({ }^{\circ} \mathbf{C}\right)\end{array}$ & $\begin{array}{c}\text { Temperatura de } \\
\text { Colapso / } \\
\text { Microcolapso } \\
\left({ }^{\circ} \mathbf{C}\right)^{*}\end{array}$ & $\begin{array}{c}\text { Temperatura } \\
\text { Segura de } \\
\text { Liofilização } \\
\left({ }^{\circ} \mathbf{C}\right)\end{array}$ \\
\hline Quitosana 2\% & $-18,0$ & $-10,0$ & -15 \\
N-Succinil-quitosana 1\% & $-18,9$ & $-35,0$ & -40 \\
Fibroína de seda 2\% & $-23,8$ & $-25,5$ & -30 \\
Fibroína/Quitosana $(1: 1)$ & $-19,7$ & $-15,0$ & -20 \\
\hline
\end{tabular}

${ }^{\star}$ Sempre considerando a temperatura mais baixa.

As figuras 38-41 mostram as imagens obtidas durante os processos de congelamento e liofilização. As amostras foram congeladas até uma temperatura de $-50^{\circ} \mathrm{C}$, utilizando-se uma taxa de resfriamento de $10^{\circ} \mathrm{C} / \mathrm{min}$ e após 5 minutos nesta temperatura iniciou-se o processo de liofilização, acionando-se a bomba a vácuo e aumentando-se a temperatura na taxa de aquecimento de $5^{\circ} \mathrm{C} / \mathrm{min}$. 
A partir das imagens é possível observarmos as soluções, o congelamento e o início da liofilização (setas no terceiro ou quarto quadro). É possivel acompanhar a liofilizaçao até o início do microcolapso ou do colapso (também indicados por setas).
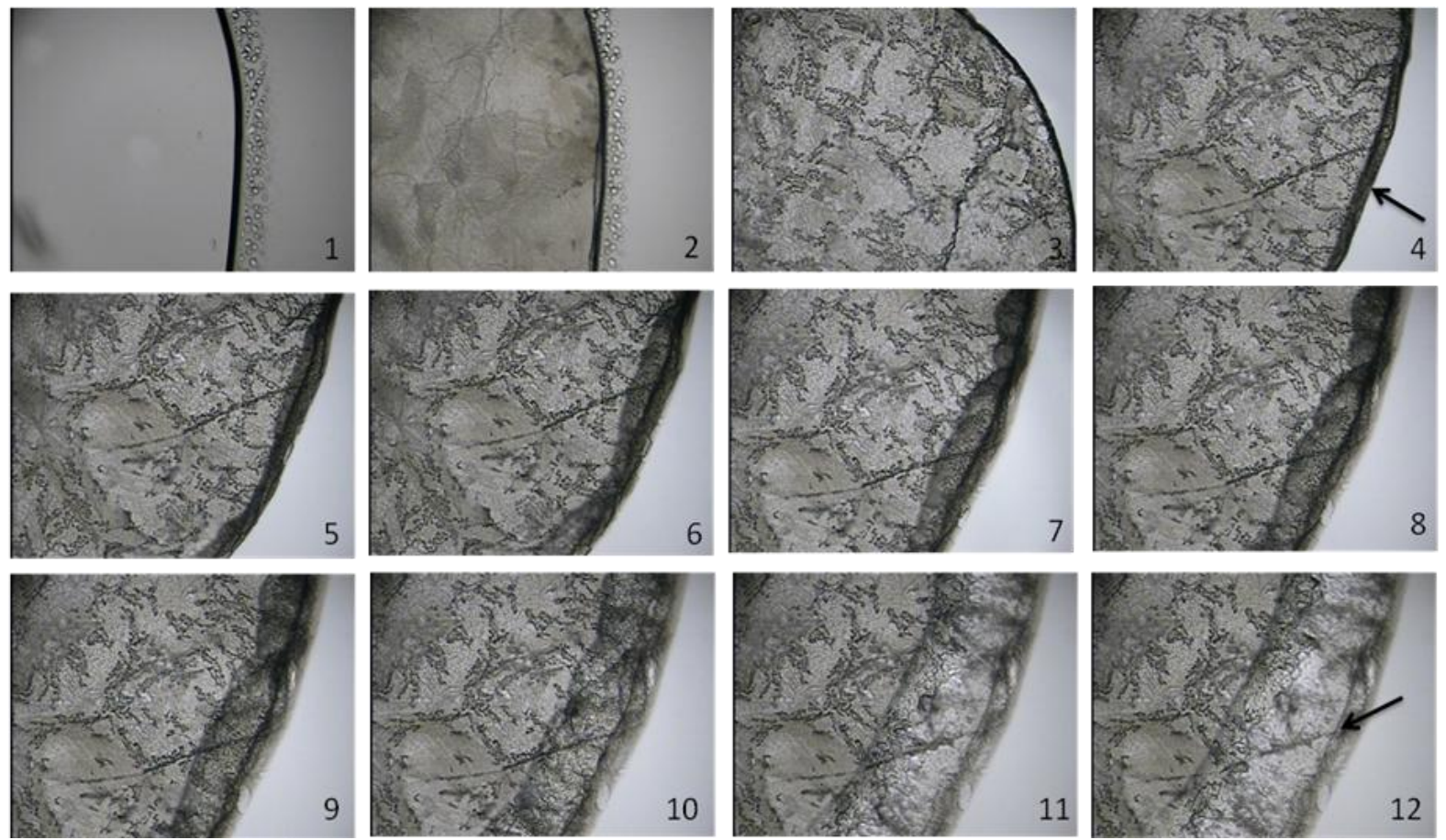

Figura 38. Microfotografias da liofilização da N-succinil-quitosana $1 \%$ obtidas pelo Lyostat com um aumento de 100x. 

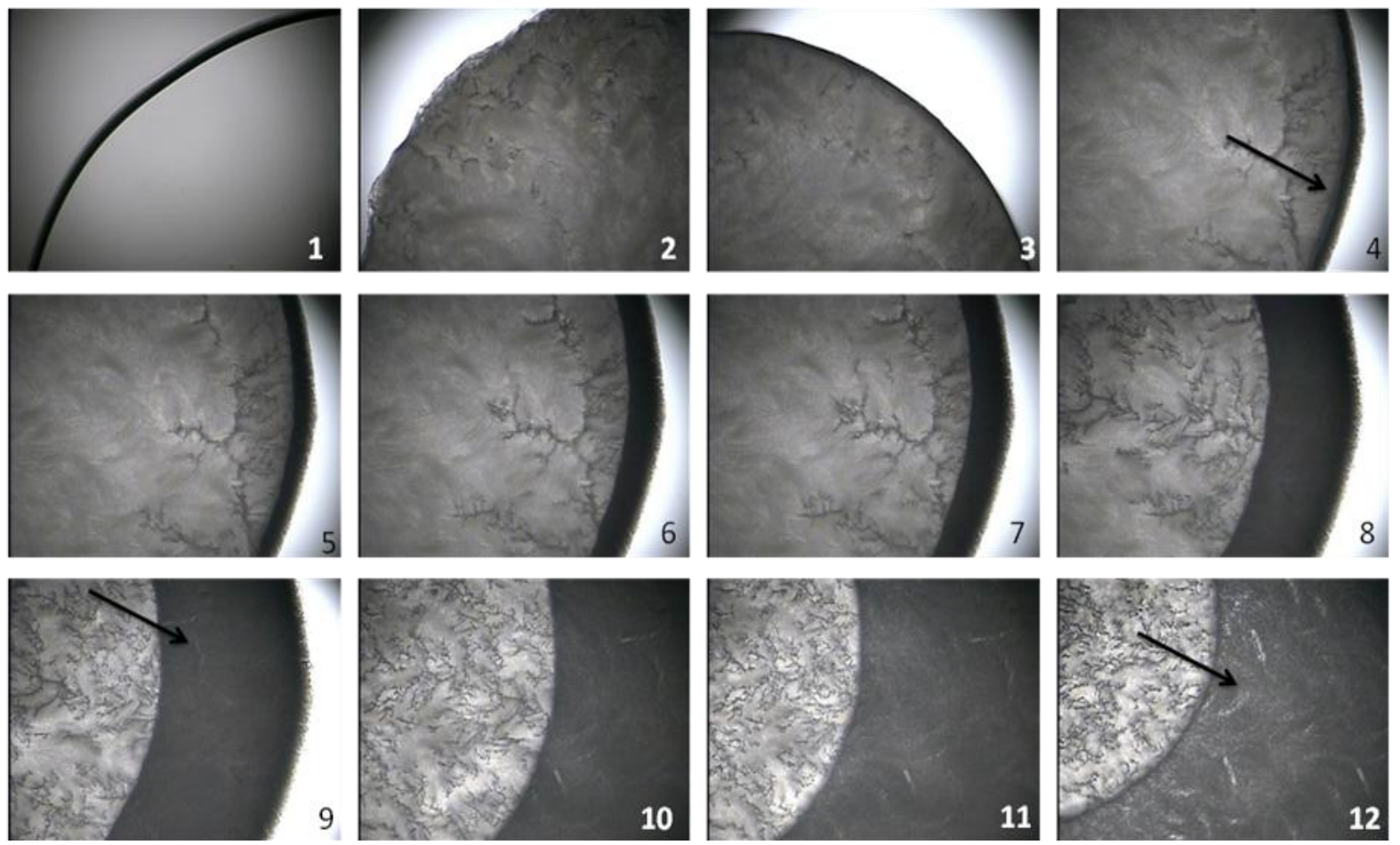

Figura 39. Microfotografias da liofilização da fibroína de seda $2 \%$ obtidas pelo Lyostat com um aumento de 100x.
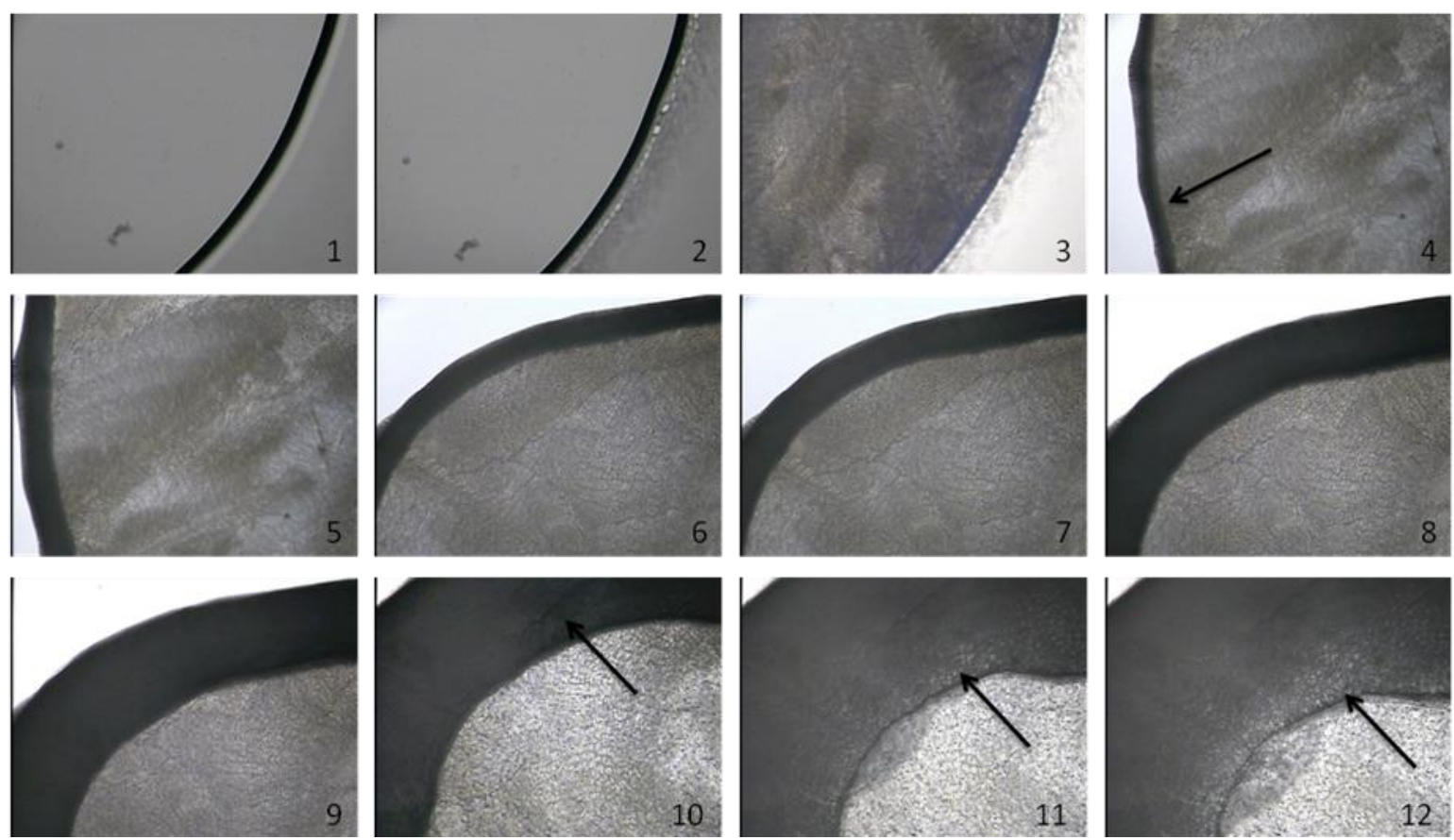

Figura 40. Microfotografias da liofilização solução híbrida de quitosana e fibroína de seda, ambas a 2\% (1:1), obtidas pelo Lyostat com um aumento de 100x. 

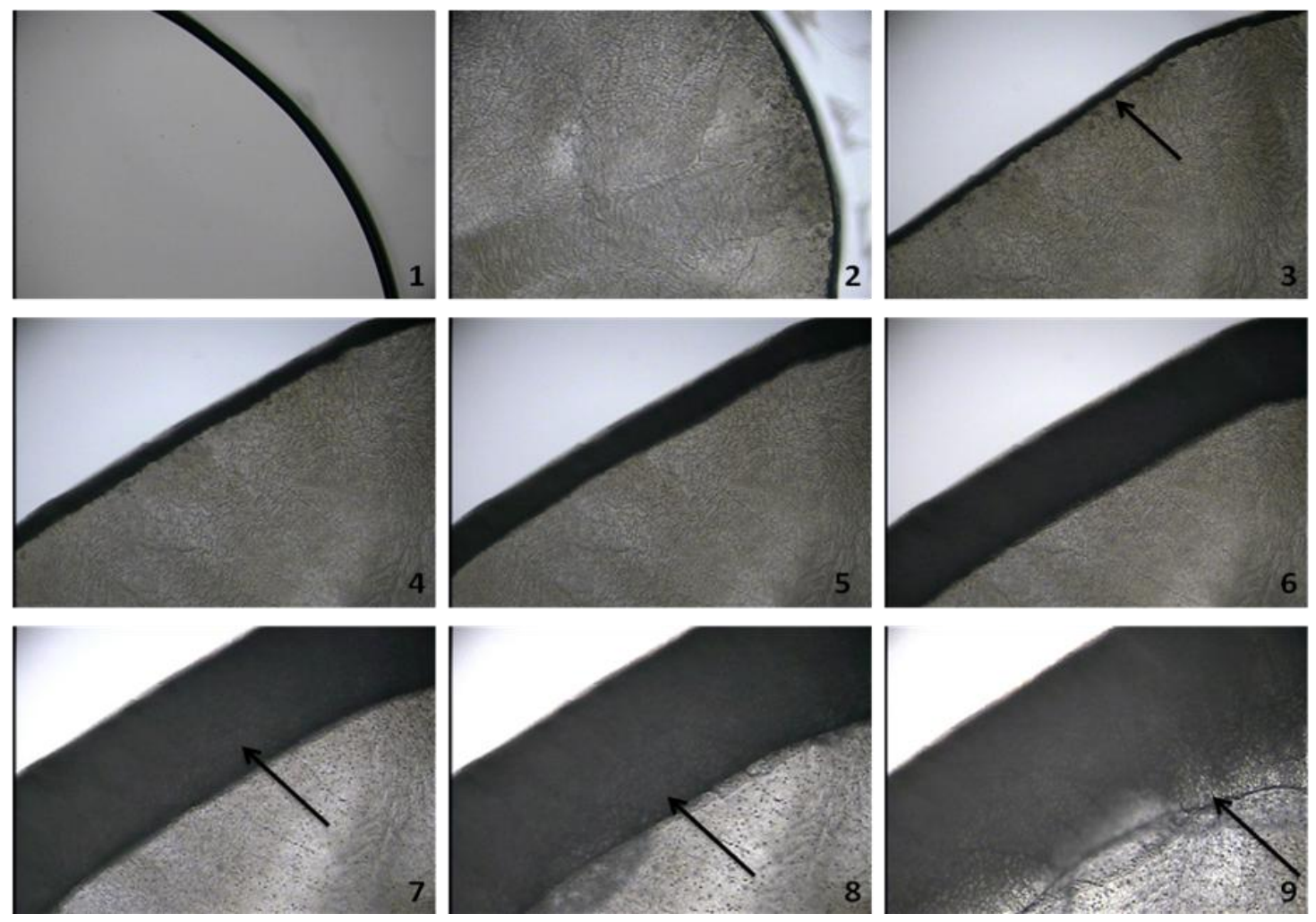

Figura 41. Microfotografias da liofilização solução de quitosana $2 \%$ em solução aquosa de ácido acético 1\%, obtidas pelo Lyostat com um aumento de 100x.

A partir dos resultados de intumescimento foi possível determinar 0 tempo de contato para maior absorção das diferentes soluções pelo tecido liofilizado de PB. De acordo com os resultados obtidos pela microscopia ótica acoplada ao modulo de liofilização podemos verificar a temperatura de liofilização para cada solução a fim de não interferir em suas propriedades, principalmente mecânicas, após a secagem. Ainda, de acordo com os resultados sobre a temperatura de colapso foi possível verificar que a solução de quitosana modificada ( $\mathrm{N}$-succinil-quitosana) apresenta uma temperatura de liofilização muito baixa $\left(-40^{\circ} \mathrm{C}\right)$, tornando inviável sua utilização para impregnação e posterior liofilização. Por este motivo, decidimos utilizar a quitosana $2 \%$ em solução aquosa de ácido acético para realizar as modificações no tecido de PB.

Após a determinação dos parâmetros acima citados, as modificações foram realizadas seguindo os protocolos descritos na seção 4.16. 


\subsubsection{Caraterização das amostras via espectroscopia vibracional Raman}

A espectroscopia vibracional Raman é apontada como uma excelente técnica de caracterização e monitoramento de inumeráveis substâncias químicas devido a sua fácil manipulação e rápida resposta. Atualmente é utilizada satisfatoriamente em diversas áreas da indústria farmacêutica (VANKEIRSBILCK et al., 2002). Sendo uma ferramenta poderosa na investigação de estruturas e interações de muitas moléculas simples e complexas, assinala-se de grande vantagem, em comparação a outras técnicas vibracionais, como por exemplo, sua facilidade de identificação do analito em soluções aquosas (JASTRZEBSKA et al., 2005).

No presente estudo, após das modificações citadas, as amostras de PB conjugadas com as soluções de $Q$ e SF foram caracterizadas por espectroscopia Raman. Para tanto, foi necessario caracterizar primeiramente cada material separadamente. Cada solução preparada nas concentrações mencionadas acima foram liofilizadas e então analisadas por Raman.

\section{Caracterização da quitosana}

A Figura 42 exibe o espectro da quitosana através da espectroscopia Raman na região espectral dos $800 \mathrm{~cm}^{-1}$ até os $1700 \mathrm{~cm}^{-1}$. O espectro coletado foi comparado com espectros adquiridos por outros grupos de pesquisa (VASCONCELOS et al., 2008; VITALI; LARANJEIRA; FÁVERE, 2008; ORREGO et al., 2010) onde foi observada uma grande concordância tanto no formato espectral como na intensidade dos picos. Na mesma Figura, os picos observados devem-se principalmente a estiramentos simétricos da ligação CO-C na região dos $970-800 \mathrm{~cm}^{-1}$ (SCHRADER, 1995) e wagging do $\mathrm{NH}_{2}$ no modo fora de fase (segundo a Figura em $923 \mathrm{~cm}^{-1}$ ) verificado por Orrego et al. (2010) e Jastrzebska et al. (2005). Assim mesmo, estiramentos antisimétricos da ligação C-O-C foram identificados na região dos $1150-1060 \mathrm{~cm}^{-1}$ (SCHRADER, 1995). Vibrações no modo bending para ligações $\mathrm{CH}\left(1262 \mathrm{~cm}^{-1}\right)$, $\mathrm{CH}_{2}$ de deformação $\left(1340 \mathrm{~cm}^{-1}\right)$ e simétrico $\left(1459 \mathrm{~cm}^{-1}\right)$ e $\mathrm{CH}_{3}$ simétrico (1380 $\mathrm{cm}^{-1}$ ), adicionalmente, foi verificado a presença de Amida II em $1584 \mathrm{~cm}^{-1}$ (reportado por KANTI et al., 2004). Após a irradiação podem ser observadas 
alterações nas intensidades dos picos compreendidos nas faixas espectrais dos $850-960 \mathrm{~cm}^{-1}$ e dos $1340-1480 \mathrm{~cm}^{-1}$, atribuído a modificações do estiramento $\mathrm{CH}_{2}, \mathrm{NH}_{2}$ e $\mathrm{CH}_{2}-\mathrm{CH}_{3}$ (simétrico) respectivamente, devido à irradiação.

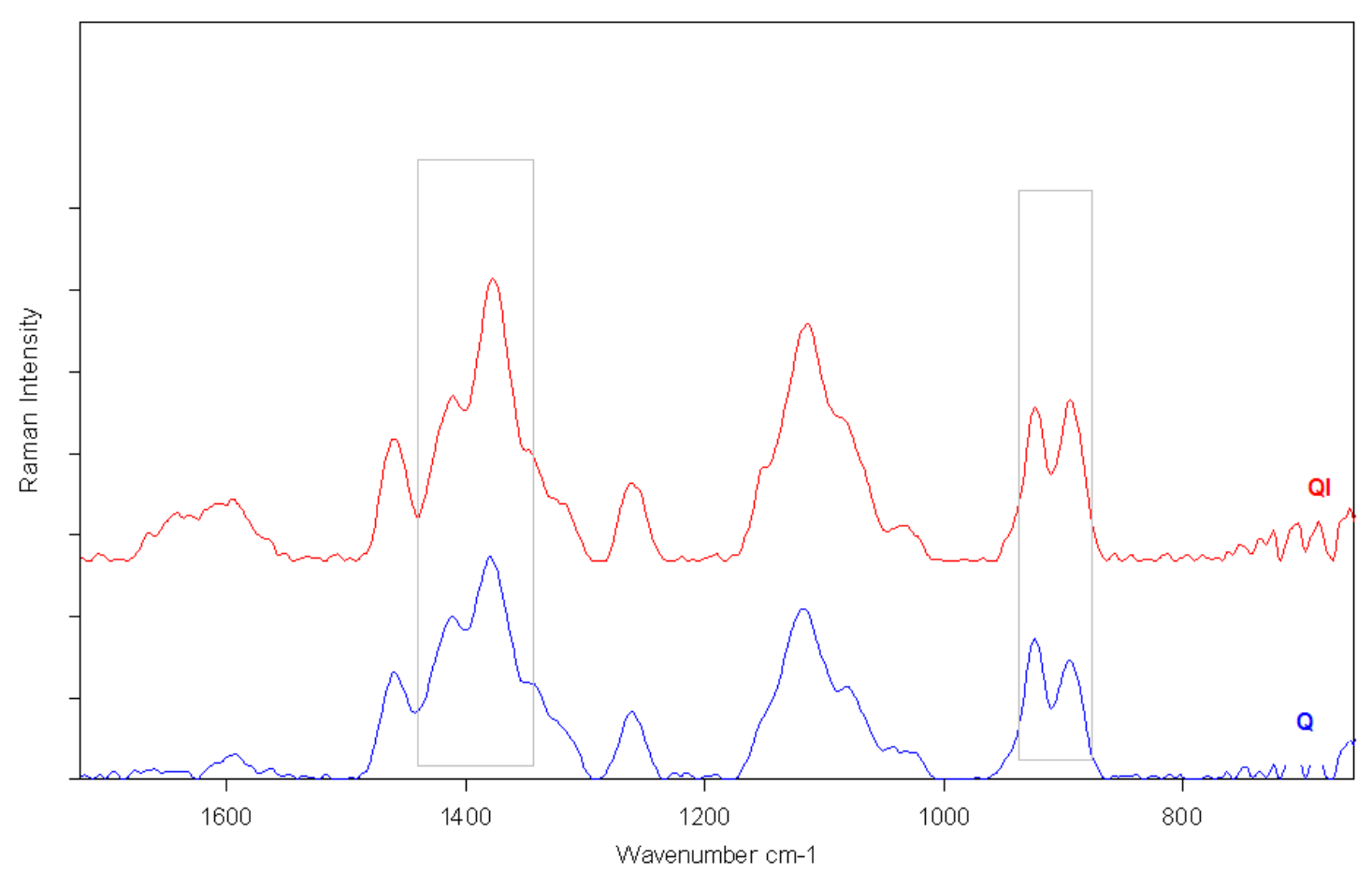

Figura 42. Representação espectral da quitosana nativa e irradiada através da espectroscopia Raman.

\section{Caracterização da fibroína de seda}

Vários grupos de pesquisa caracterizaram esta proteína através da espectroscopia Raman, mencionado, por exemplo, Monti et al. (2005) que verificaram a degradação biológica da a.p. fibroína por uma protease bacterial e a oxidação da b.m. fibroína pela enzima "mushroom tyrosinase" com o subseqüente acoplamento da quitosana. Anteriores trabalhos foram realizados por Tsukada et al. (1995, apud MONTI et al., 2005) e Tsukada et al. (1998, apud MONTI et al., 2005) sobre estudos preliminares e os realizados por Frushour et al., (1974, apud MONTI et al., 2005) que caracterizaram através desta técnica os picos que correspondem às ligações das amidas I e III e outros segmentos na cadeia da fibroína. 
Segundo a Figura 43, a fibroína caracterizada neste estudo apresenta uma boa concordância com os estudos realizados por Preghenella, Pezzotti e Migliaresi (2007); Shao et al. (2005); Sirichaisit et al. (2003); Monti et al. (2005) e por Chen, Li e Yu (1997), assinalados na Tabela 7.

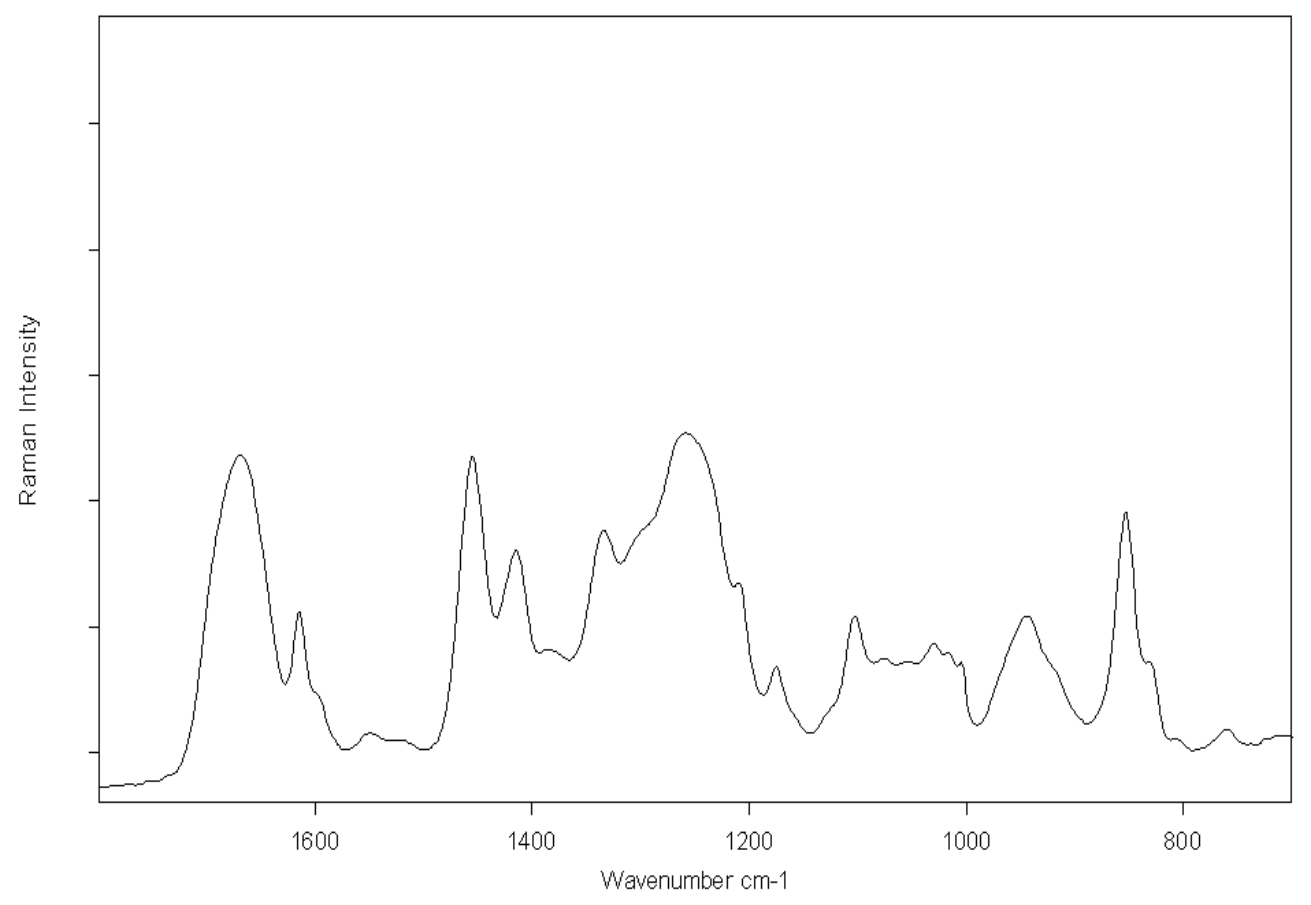

Figura 43. Representação espectral da fibroína através da espectroscopia Raman.

$\mathrm{Na}$ figura 44 apresentam-se os espectros da fibroína nativa e irradiada. Como pode ser observado, os espectros não reportaram nenhuma alteração significativa desta proteína após a irradiação na ausência de oxigênio na dose de 25 kGy.

Cabe destacar que, ambas as amostras apresentam picos em $1668 \mathrm{~cm}^{-1}$, atribuído ao grupo carbonila (Amida I, folha- $\beta$ ), embora as amostras liofilizadas e irradiadas apresentarem predominantemente a conformação de "estrutura ao acaso" (random coil). Isto indica provavelmente, que a liofilização pode 'induzir' a uma alteração parcial da conformação desta proteína ou durante o processo de diálise, parte desta proteína tende a se regenerar. Maiores estudos deverão ser realizados. 


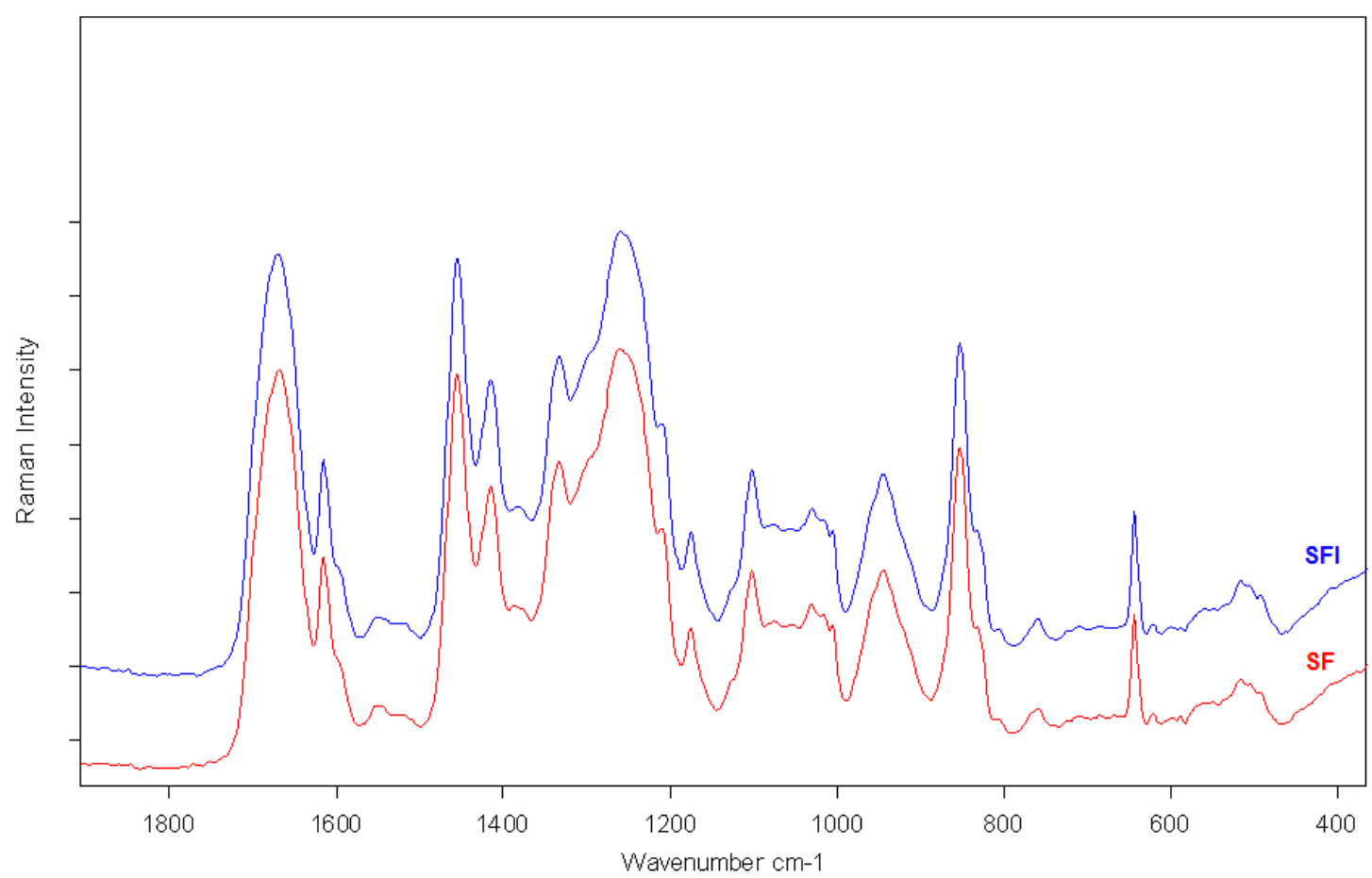

Figura 44. Representação espectral da fibroína de seda nativa e irradiada através da espectroscopia Raman.

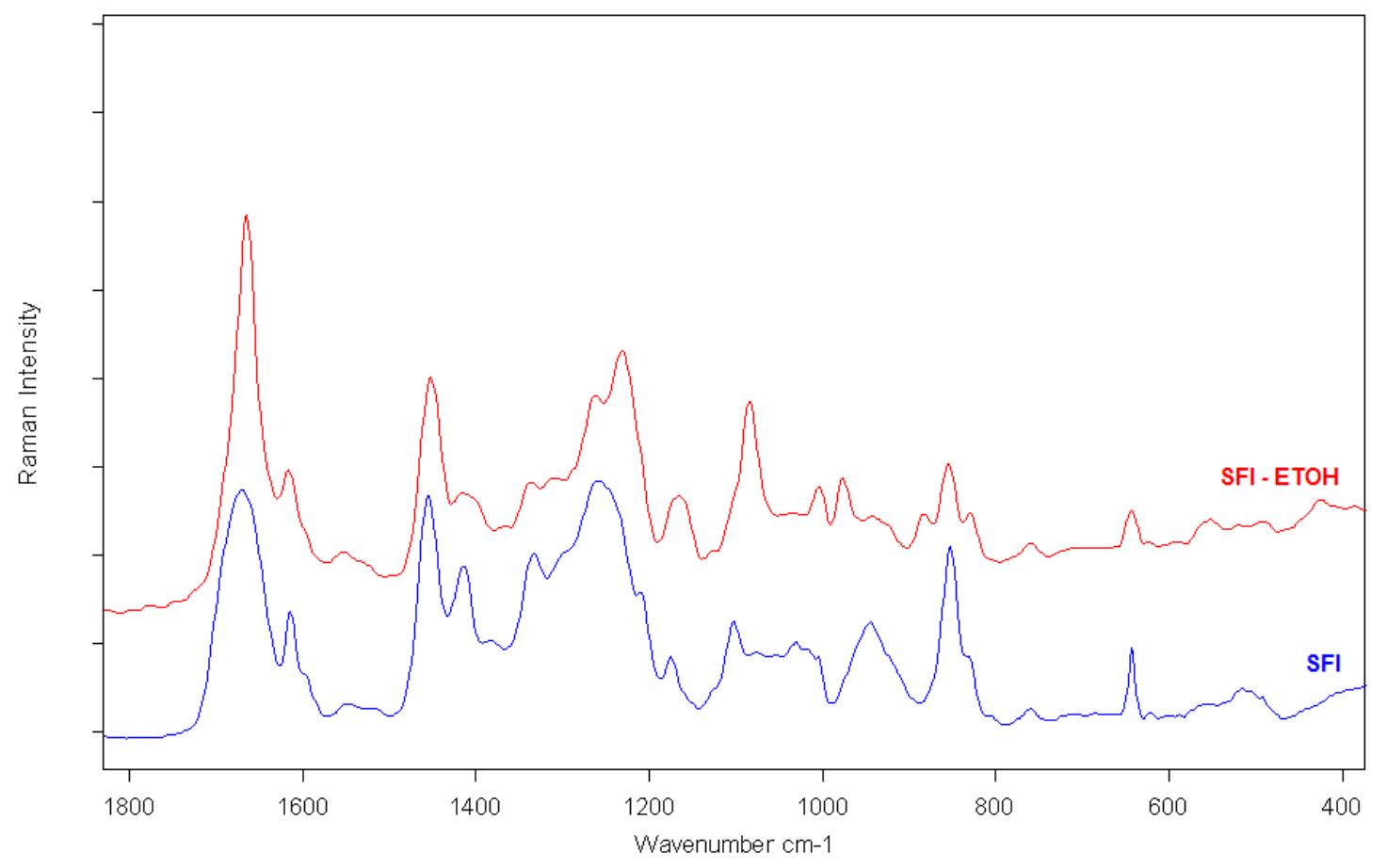

Figura 45. Representação espectral da fibroína de seda irradiada e tratada com etanol $70 \%$ e fibroína de seda irradiada através da espectroscopia Raman. 
Na Figura 45 podem-se observar alterações na conformação da SF após o tratamento com solução de etanol $70 \%$, apresentando picos característicos da folha- $\beta$. A Tabela 8 mostra com mais detalhes os picos representativos de ambas as conformações que a SF pode apresentar.

Tabela 8. Atribuições de banda no espectro Raman da SF liofilizada e tratada com etanol.

\begin{tabular}{|c|c|c|}
\hline \multicolumn{2}{|c|}{$\operatorname{Pico}\left(\mathrm{cm}^{-1}\right)$} & \multirow[t]{2}{*}{ Atribuição $^{\text {a }}$} \\
\hline SF liofilizada & SF - EtOH & \\
\hline 1668 & 1664 & Amida I (folha- $\beta$ ) \\
\hline 1614 & 1616 & Anéis aromáticos em fenilalanina e tirosina \\
\hline 1553 & 1553 & Triptofano \\
\hline 1455 & 1451 & $\begin{array}{l}\delta \mathrm{CH}_{2}, \mathrm{CH}_{3} \text { flexão antissimétrica em poli } \\
\text { (alanina) e, } \mathrm{CH}_{2} \delta \text { em poli (alanina, glicina) }\end{array}$ \\
\hline 1414 & 1416 & $\delta \mathrm{C}^{\alpha} \mathrm{H}_{2}$ \\
\hline 1333 & 1337 & $\delta \mathrm{CH}_{3}$ \\
\hline & 1308 & $\mathrm{CH}$ \\
\hline 1259 & 1262 & Amida III, conformação ao acaso \\
\hline & 1231 & Amida III, folha- $\beta, \delta \mathrm{CH}_{2}$ \\
\hline 1174 & 1165 & $v \mathrm{CC}$ \\
\hline 1102 & & $\begin{array}{l}v \mathrm{CC} \text { alongamento do esqueleto, Ala }(v \mathrm{CaC} \beta+\rho \\
\left.\mathrm{CH}_{3}\right)\end{array}$ \\
\hline & 1084 & $\begin{array}{l}v \text { CC alongamento do "esqueleto", folha- } \beta \text {, } \\
\text { conformação ao acaso }\end{array}$ \\
\hline 1030 & & Fenilalanina \\
\hline & 1004 & Anéis aromáticos em fenilalanina e tirosina \\
\hline & 976 & $\rho \mathrm{CH}_{3}$ \\
\hline 944 & & $v \mathrm{CC}$ \\
\hline & 882 & $\rho \mathrm{CH}_{2}$ \\
\hline 852 & 855 & Tirosina \\
\hline & 829 & Tirosina \\
\hline 759 & 759 & Triptofano \\
\hline 643 & 643 & Amida IV, anel aromático na tirosina \\
\hline
\end{tabular}

aAbreviações: v, estiramento; $\delta$, deformação; $\rho$, rocking.

Caracterização do pericárdio bovino

Na Figura 46 é apresentado o espectro do pericárdio bovino (PB) nativo via espectroscopia Raman (faixa espectral estudada: $800-1700 \mathrm{~cm}^{-1}$ ). Esta 
figura apresenta uma boa concordância com o estudo realizado por Jastrzebska et al. (2005). A Tabela 9 exibe os principais modos vibracionais deste tecido.

Tabela 9. Atribuições de banda no espectro Raman do pericárdio bovino.

\begin{tabular}{l|l}
\hline Pico $\left(\mathbf{c m}^{-1}\right)$ & Atribuição \\
\hline 816 & Deformação $-\mathrm{C}-\mathrm{O}-\mathrm{C}-$ \\
856 & Aromático $-\mathrm{C}-\mathrm{C}-$ \\
874 & Aromático $-\mathrm{C}-\mathrm{C}-$ \\
921 & $\mathrm{CH}_{2}$ wagging fora de fase \\
938 & Estiramento $-\mathrm{C}-\mathrm{C}-$ \\
1004 & $-\mathrm{C}-\mathrm{C}-$ do anel da fenilalanina \\
1033 & Estiramento $-\mathrm{C}-\mathrm{C}-$ de anel piridinico \\
1062 & Deformação $-\mathrm{C}-\mathrm{O}-\mathrm{C}-$ \\
1101 & Estiramento assimétrico -C - O - C - \\
1127 & Estiramento $(\mathrm{COC}) /(\mathrm{CN})$ \\
1174 & Estiramento $-\mathrm{C}-\mathrm{C}-$ da Tirosina \\
1207 & Estiramento $\left(\mathrm{C}-\mathrm{C}_{6} \mathrm{H}_{5}\right)$ \\
1245 & Estiramento $(\mathrm{CN}) / \mathrm{Amida}$ III \\
1272 & Deformação $(\mathrm{NH}) /$ Amida III \\
1319 & Deformação bending $(\mathrm{C}-\mathrm{OH})$ \\
1341 & Deformação $\mathrm{CH}_{2}, \mathrm{CH}$ \\
1451 & Deformação/tessoura $($ scissor $) \mathrm{CH}$ \\
1666 & Estiramento $(\mathrm{C}=\mathrm{O}) /$ Amida I \\
\hline
\end{tabular}




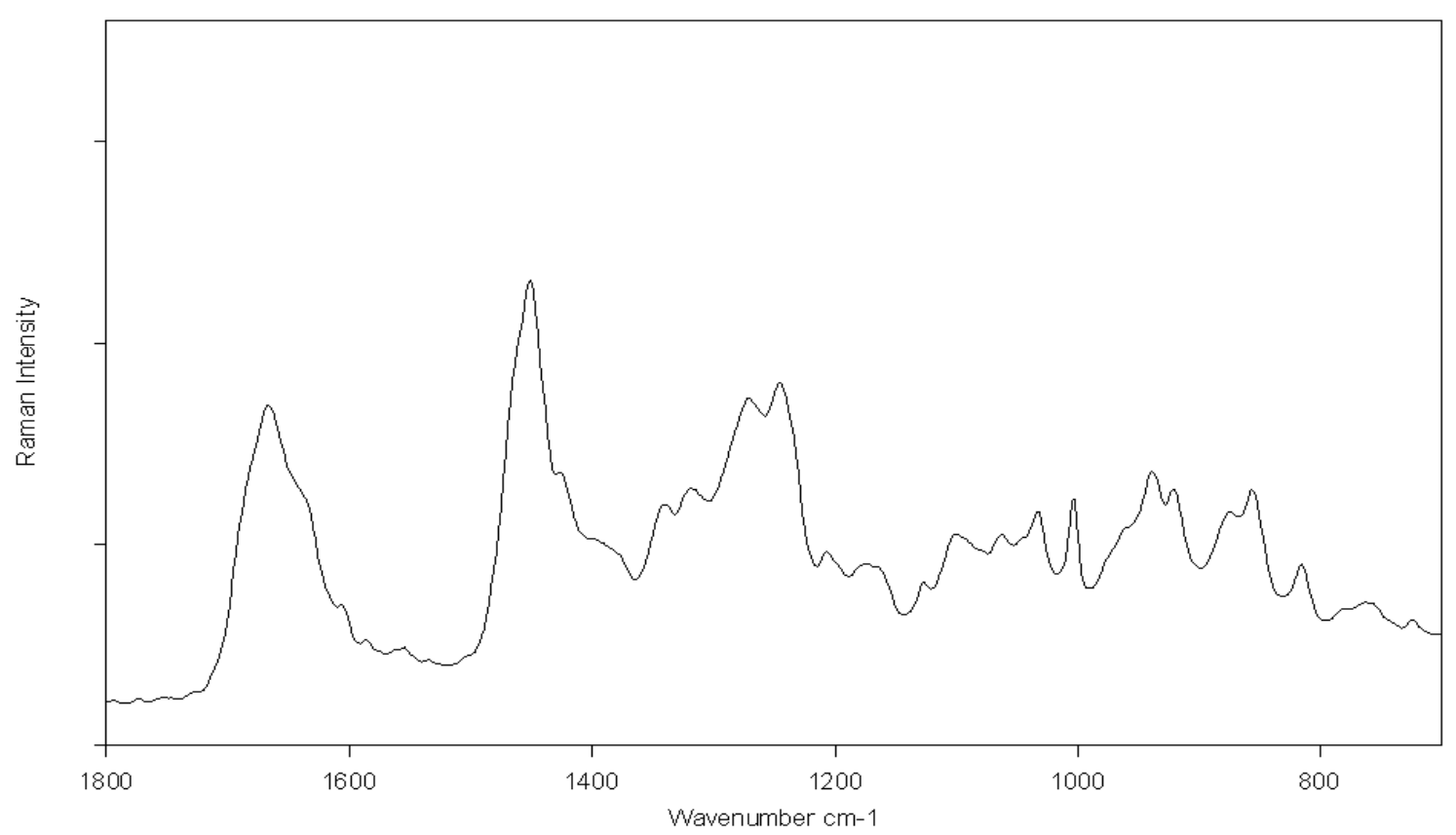

Figura 46. Representação espectral do pericárdio bovino através da espectroscopia Raman.

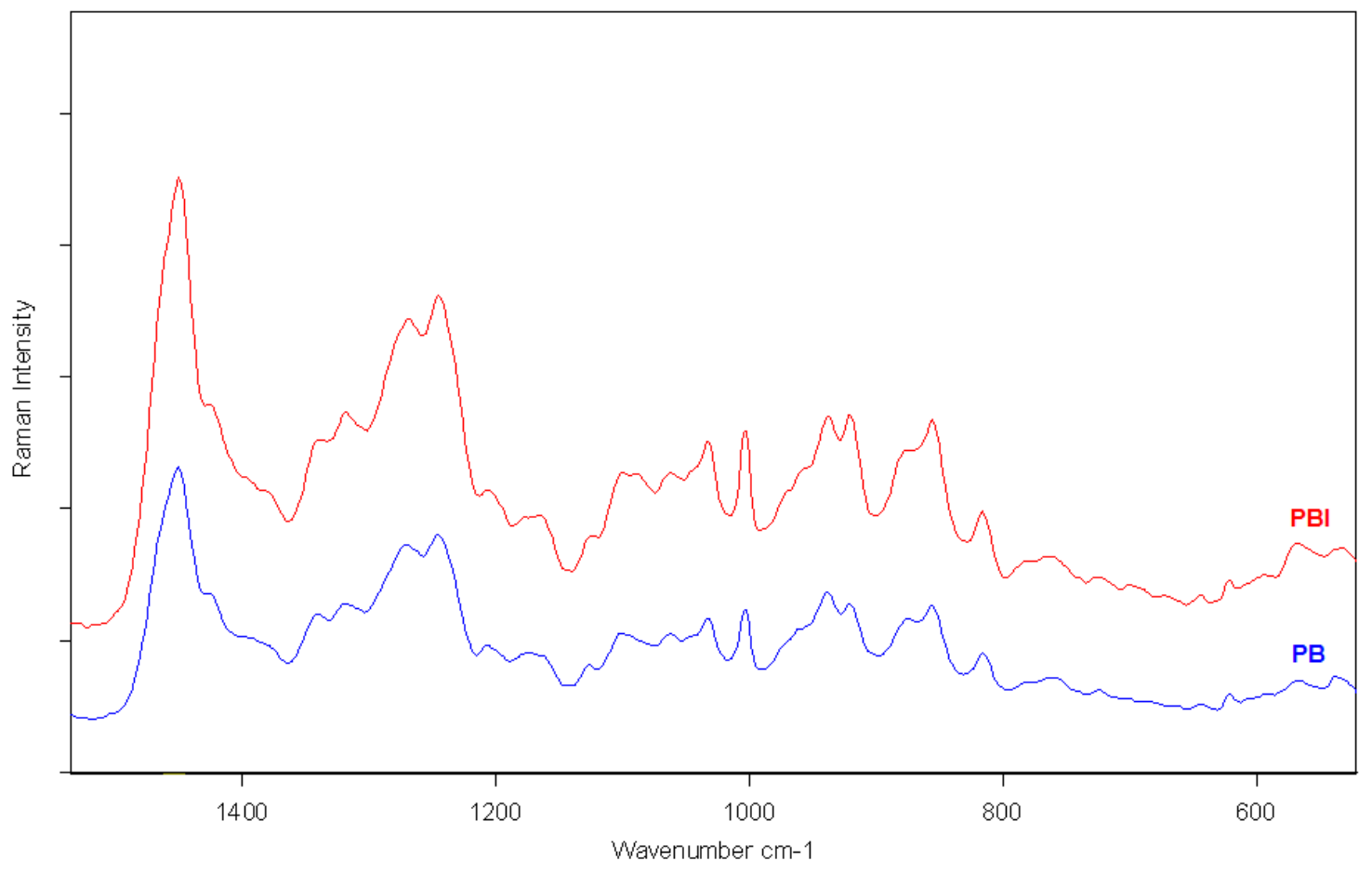

Figura 47. Representação espectral do pericárdio bovino antes (PB) e depois (PBI) da irradiação através da espectroscopia Raman. 
De acordo com a Figura 47, foi observado também alterações após da irradiação nas regiões espectrais atribuídos aos movimentos vibracionais $\mathrm{CH}_{2} \mathrm{e}$ $\mathrm{CH}_{3}$ (observado também na Figura 45), presentes nos resíduos de aminoácidos do biopolímero. Diante a estes resultados podemos concluir que, através da espectroscopia vibracional Raman pode-se também evidenciar as alterações produzidas pela irradiação nas diferentes amostras em estudo. As diferentes conjugações entre as amostras em estudo também foram caracterizadas.

\section{Quitosana x Fibroína}

Em referência às misturas de quitosana e fibroína (SFQ), através desta técnica, foi possível identificar variações nas intensidades assim como também no formato dos espectros enquanto a concentração de um dos compostos é maior na mistura, portanto, quanto maior a concentração de SF na mistura, maior será a intensidade dos picos em 1668, 1614, 1455, 1414, 1259 e $852 \mathrm{~cm}^{-1}$, e existirá uma diminuição da intensidade caso a concentração de $Q$ é maior (vide Figura 48). As amostras irradiadas apresentaram o mesmo comportamento (intensidade/formato espectral) de acordo com cada concentração de cada componente na mistura.

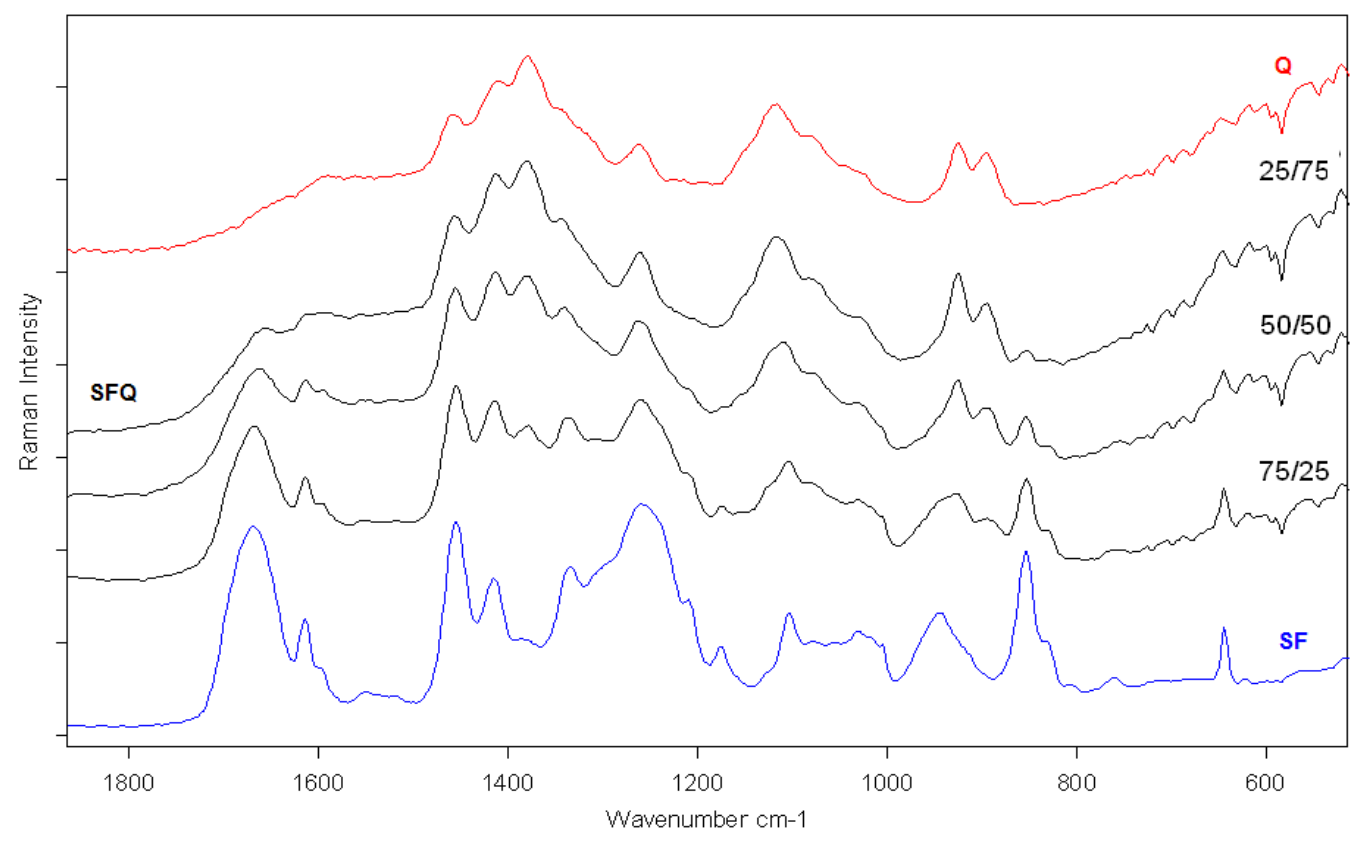

Figura 48. Variação espectral entre a fibroína (SF) e a quitosana (Q) a várias concentrações (SFQ) via espectroscopia Raman. 


\section{Quitosana x Fibroína x Pericárdio (nativo e irradiado)}

As modificações de pericárdio com misturas de quitosana e fibroína (nativo e irradiado) são apresentadas nas Figuras 49-52. De acordo com a Figura 49 foram observadas alterações nas intensidades dos picos especificamente nas regiões dos movimentos vibracionais $\mathrm{CH}_{2}$ produto da irradiação da mistura pericárdio-quitosana (PQ). Nas Figuras 50, 51 e 52 são apresentadas as variações das intensidades produto da conjugação de todos os compostos com variações na relação QSF 3:1, 1:1 e 1:3, respectivamente. Nestas figuras podemos observar que não existe uma variação significativa nas intensidades dos picos correspondentes aos movimentos vibracionais $\mathrm{CH}_{2}$ como consequência da irradiação, isto pode ser atribuído provavelmente à presença da fibroína.

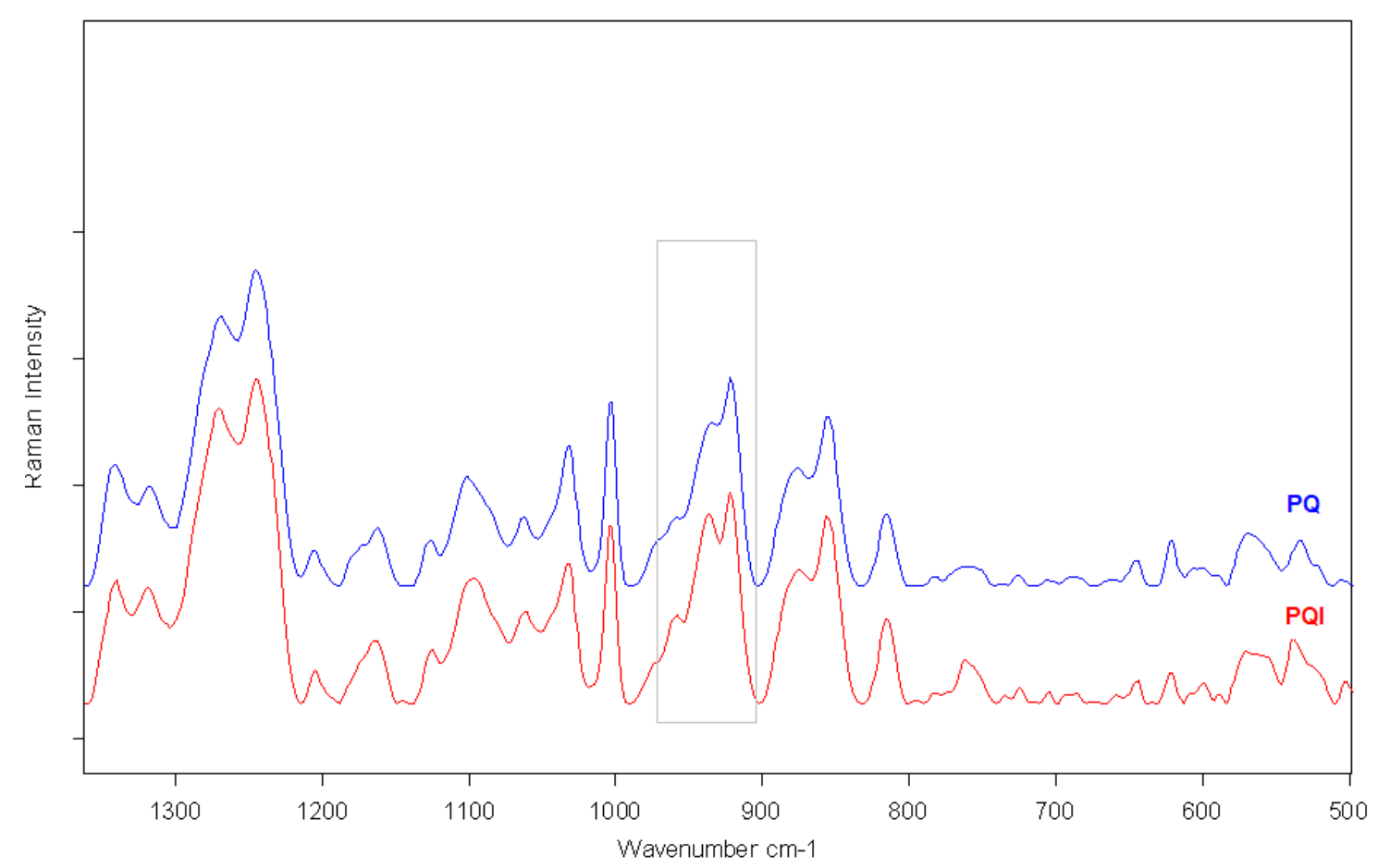

Figura 49. Representação espectral Raman para a mistura de $P B \operatorname{com} Q$ nativo e irradiado. 


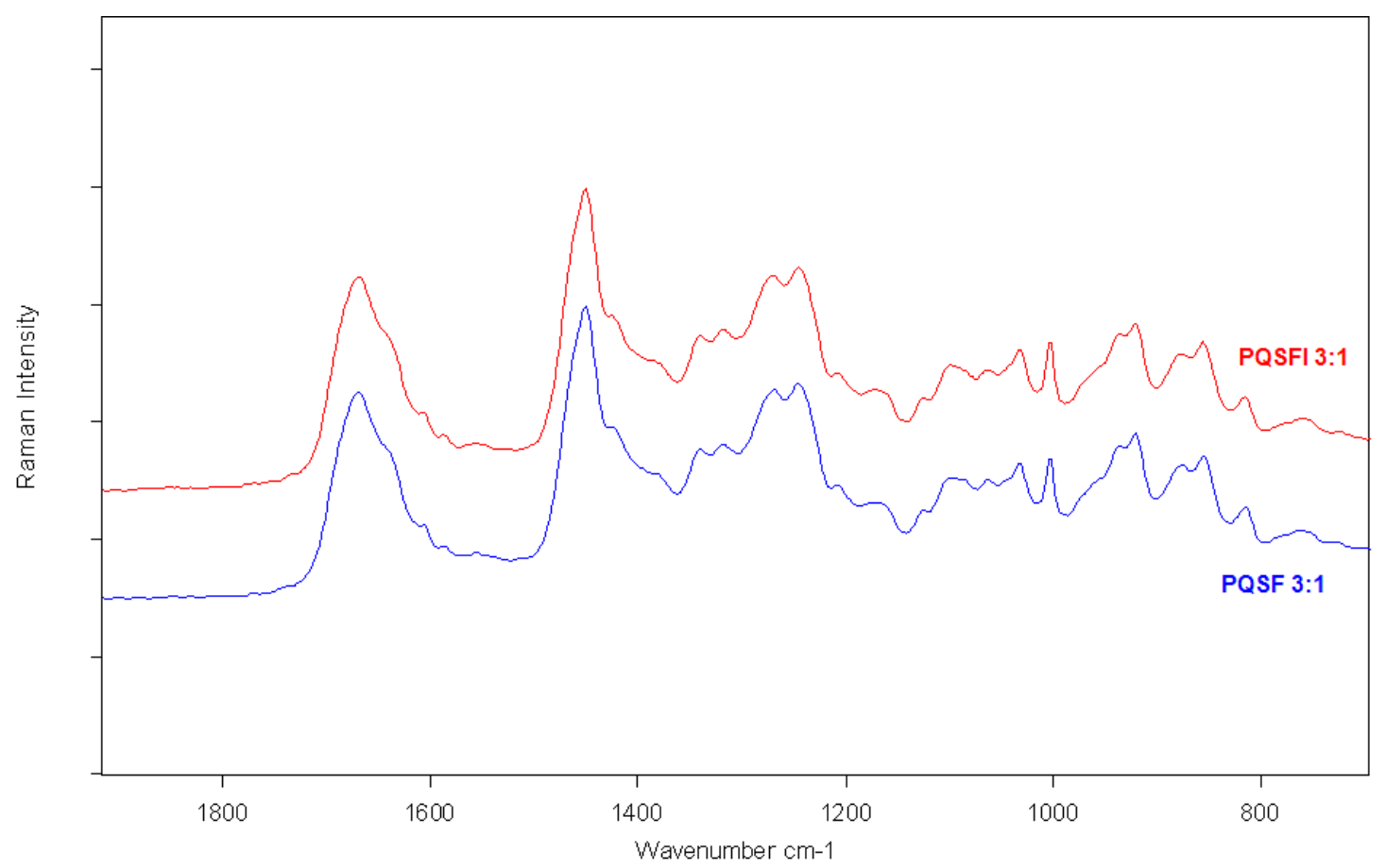

Figura 50. Representação espectral Raman do pericárdio conjugado com solução de quitosana e fibroína de seda (3:1) antes e após a irradiação.

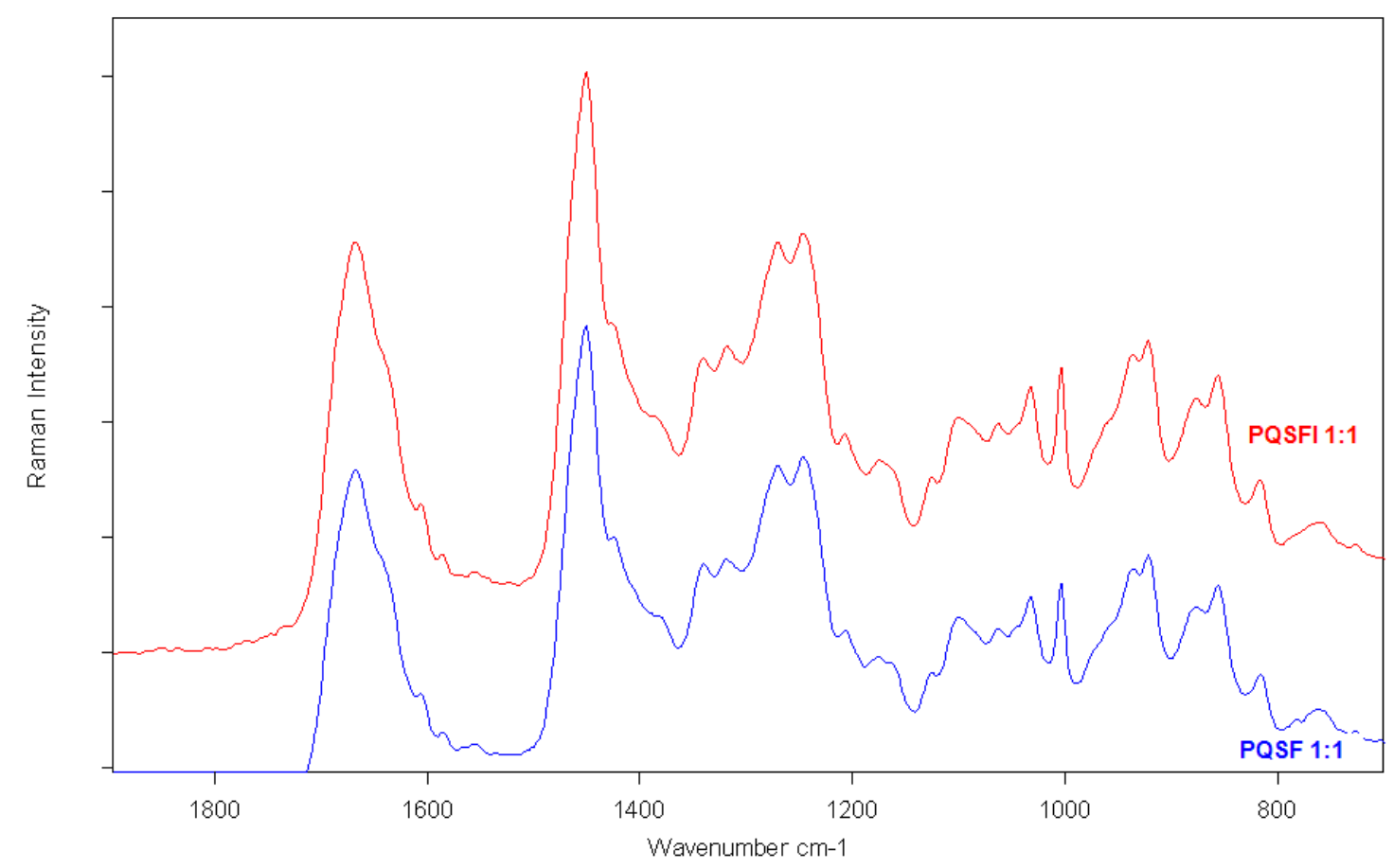

Figura 51. Representação espectral Raman do pericárdio conjugado com solução de quitosana e fibroína de seda (1:1) antes e após a irradiação. 


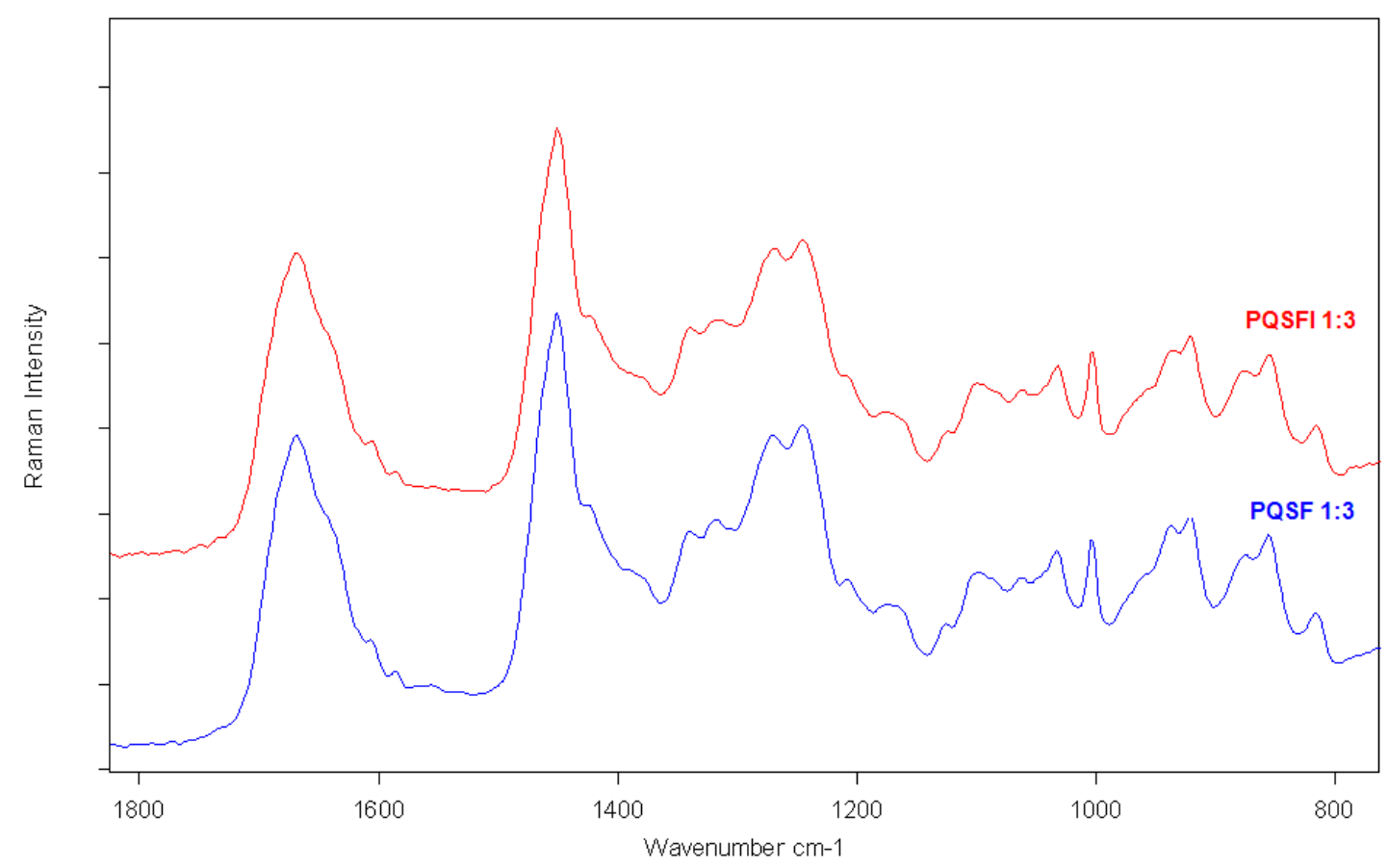

Figura 52. Representação espectral Raman do pericárdio conjugado com solução de quitosana e fibroína de seda (1:3) antes e após a irradiação.

Frente a todos estes resultados podemos concluir que, a espectroscopia Raman é uma técnica útil, rápida e de fácil manipulação na identificação de estruturas químicas complexas. Esta técnica consegue identificar variações nas intensidades dos picos, produto da irradiação em amostras de pericárdio e de quitosana, entretanto, não foi registrado nenhuma variação significativa em tecidos modificados com fibroína.

\subsubsection{Avaliação da citotoxicidade}

O objetivo deste teste foi avaliar a citotoxicidade pericárdio bovino liofilizado e intumescido com fibroína de seda, quitosana e misturas.

$\mathrm{O}$ teste de citotoxicidade pode ser realizado in vitro seguindo a Norma ISO 10993-5:1992, Biological testing of medical and dental materials devices part 5 - Tests for cytotoxicity: in vitro methods (ver Seção 4.17). Este teste é bastante útil para realização de triagem de biomaterias e nos permite verificar 
se o material pode passar para testes posteriores ou necessita de modificações durante seu processamento, por exemplo.

Os gráficos a seguir (Figuras 53-57) mostram os resultados obtidos a partir do teste de citotoxicidade das amostras modificadas com quitosana (PQ), fibroína de seda (PSF) e misturas (PQSF), irradiadas e não irradiadas (I).

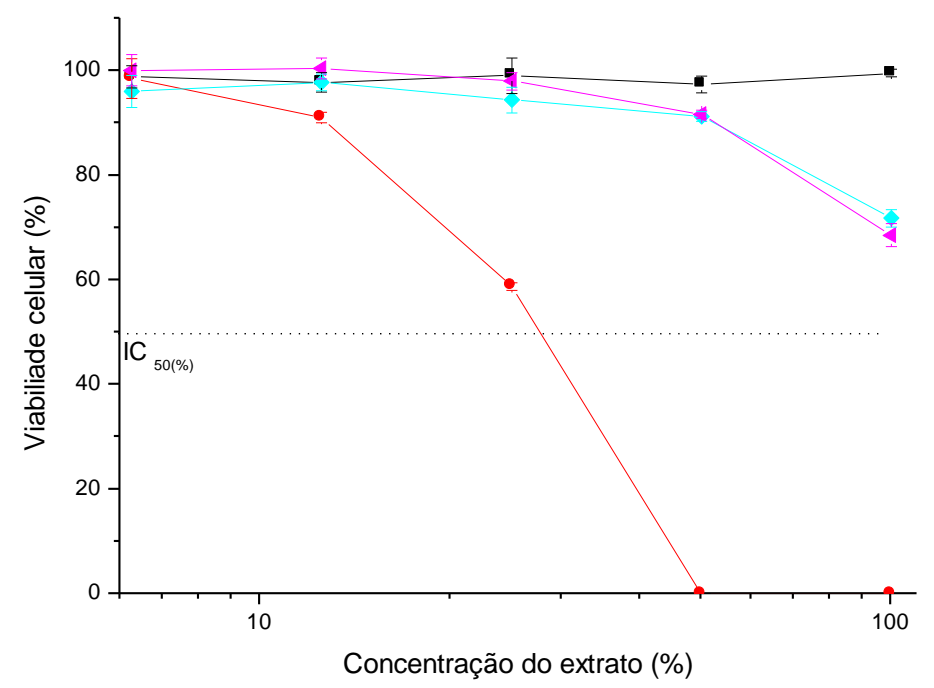

Figura 53. Curva de citotoxicidade do extrato de PSF. (๑) - Controle positivo; (घ) - Controle negativo; $(\diamond)$ - PSF (não irradiado); (४ ) - PSFI (irradiado). 


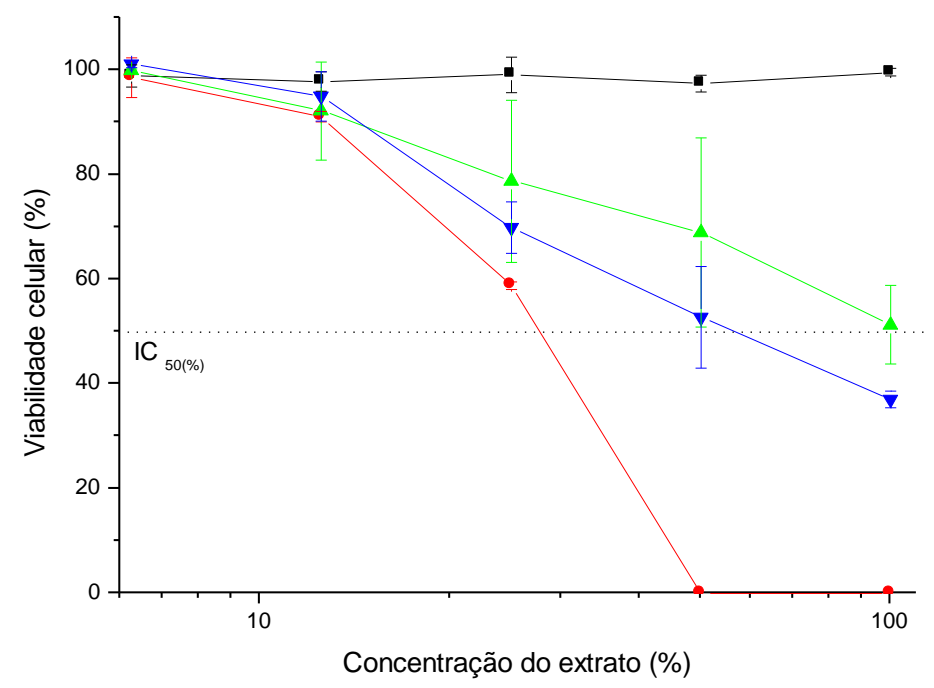

Figura 54. Curva de citotoxicidade do extrato de PQ. (•) - Controle positivo; (घ) - Controle negativo; ( ${ }^{\Delta}$ ) - PQ (não irradiado); ( $\left.\boldsymbol{\nabla}\right)$ - PQI (irradiado).

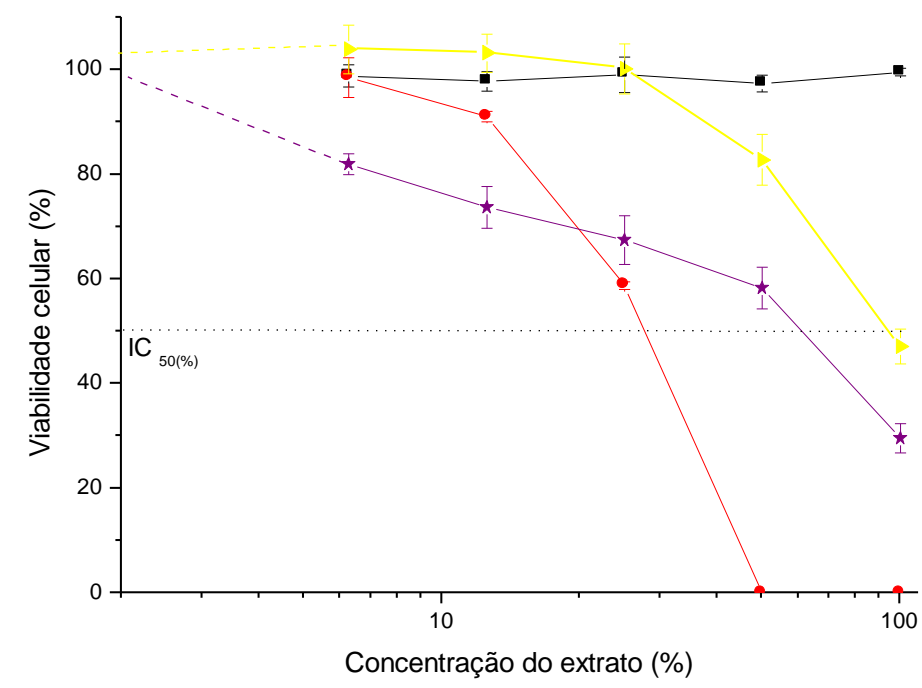

Figura 55. Curva de citotoxicidade do extrato de PQSF (3:1). (•) - Controle positivo; (घ) - Controle negativo; ( $\star$ ) - PQSF (não irradiado); ( ) - PQSFI (irradiado). 


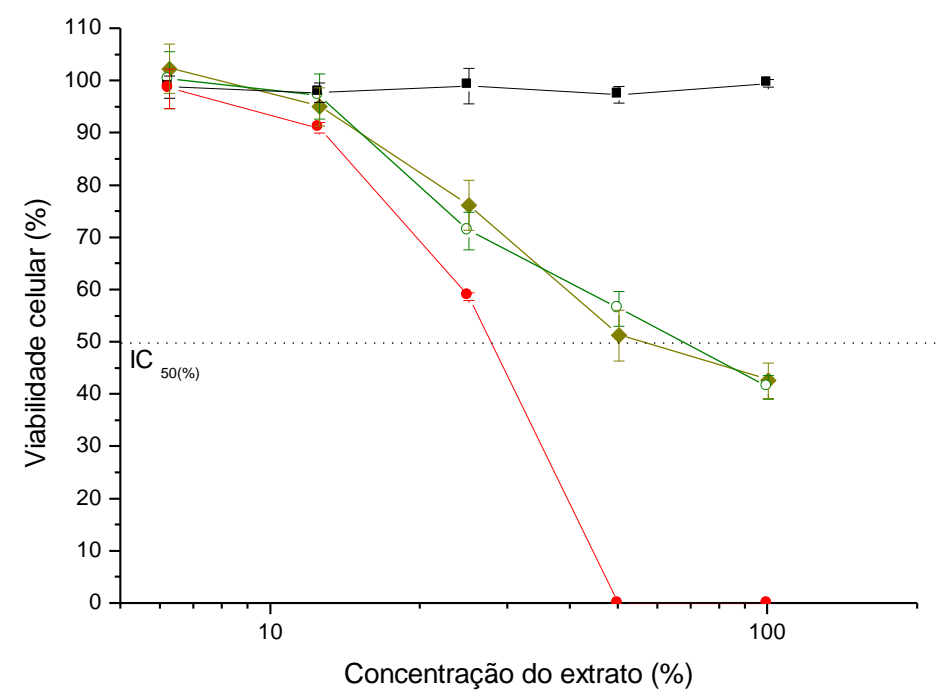

Figura 56. Curva de citotoxicidade do extrato de PQSF (1:1). (๑) - Controle positivo; (ם) - Controle negativo; (O) - PQSF (não irradiado); ( $\bullet$ ) - PQSFI (irradiado).

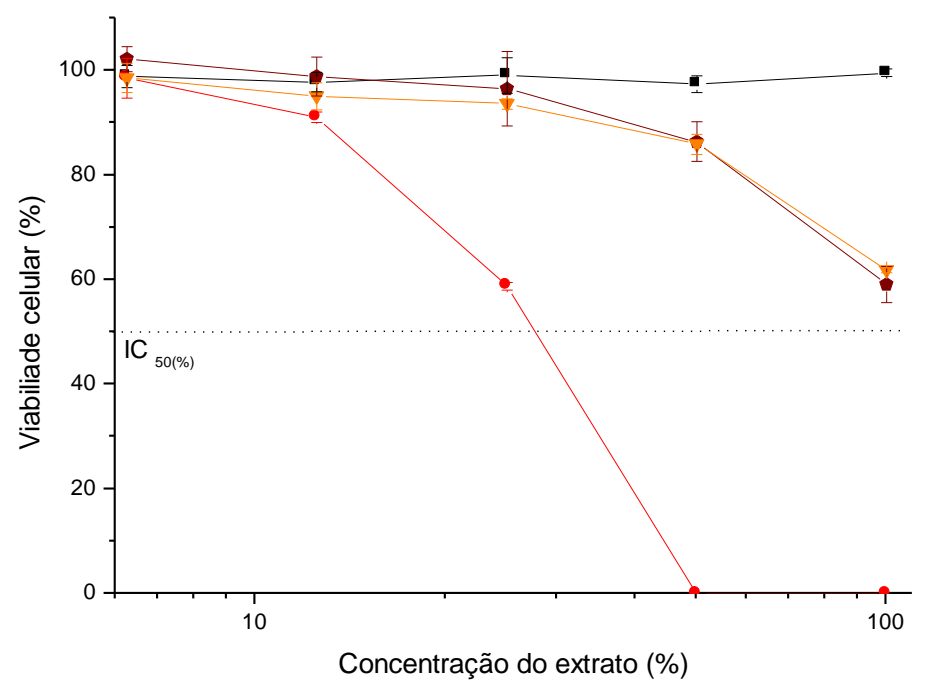

Figura 57. Curva de citotoxicidade do extrato de PQSF (1:3). (•) - Controle positivo; (घ) - Controle negativo; ( $\nabla$ ) - PQSF (não irradiado); ( $)$ - PQSFI (irradiado). 
A partir destes resultados pode-se observar que quanto menor a concentração de SF na mistura maior a toxicidade dos extratos. Isto pode estar ocorrendo, pois quando a SF é misturada em pequenas proporções a solução de quitosana ocorrem interações entre as duas (CHEN; LI; YU, 1997), deixando maior quantidade de ácido acético disponível na solução. Este ácido acético por sua vez irá levar a uma maior degradação das fibras de colágeno e, consequentemente, a um maior intumescimento da membrana. Mesmo após a liofilização, a concentração de resíduos de ácido acético será maior em relação às outras membranas, levando a uma menor viabilidade celular do extrato de $100 \%$.

De acordo com a nova edição da norma ISO 10993-5:2009, as amostras que apresentam diminuição de $30 \%$ da viabilidade celular são consideradas citotóxicas. Portanto todas as amostras deste trabalho são consideradas citotóxicas, utilizando-se a concentração de 100\% do extrato (Figura 58).

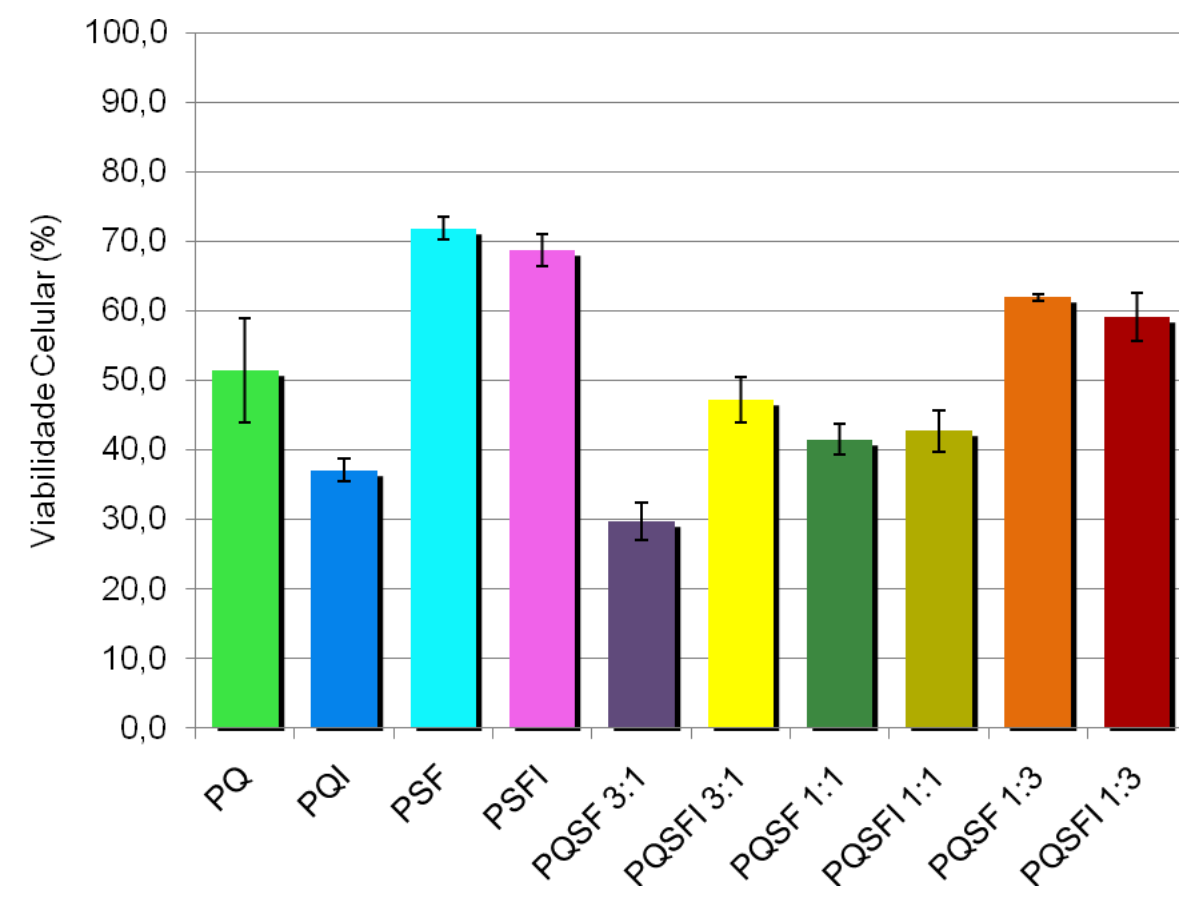

Figura 58. Viabilidade das células $\mathrm{CHO}(\%)$ nos extratos (100\%) do pericárdio bovino tratado com quitosana, fibroína de seda e misturas de quitosana/fibroína de seda. 
Esta citotoxicidade pode ser amenizada realizando-se lavagens no tecido antes de utilizá-lo (RODAS et al., 2008). No caso os componentes responsáveis pela diminuição da viabilidade celular, são o ácido acético para a quitosana e misturas, e o etanol para a fibroína de seda. Para as lavagens cada membrana foi imersa em $40 \mathrm{~mL}$ de solução fisiológica, que foi trocada a cada 48 horas por 7 dias, totalizando 3 trocas. Na água da última troca um novo teste de citotoxicidade foi realizado, mostrando que os compostos citotóxicos da membrana foram eficientemente removidos pelas lavagens, como mostrado na Figura 59.

Estes resultados mostram que apesar de citotóxicas, após as lavagens as membranas podem ser utilizadas.

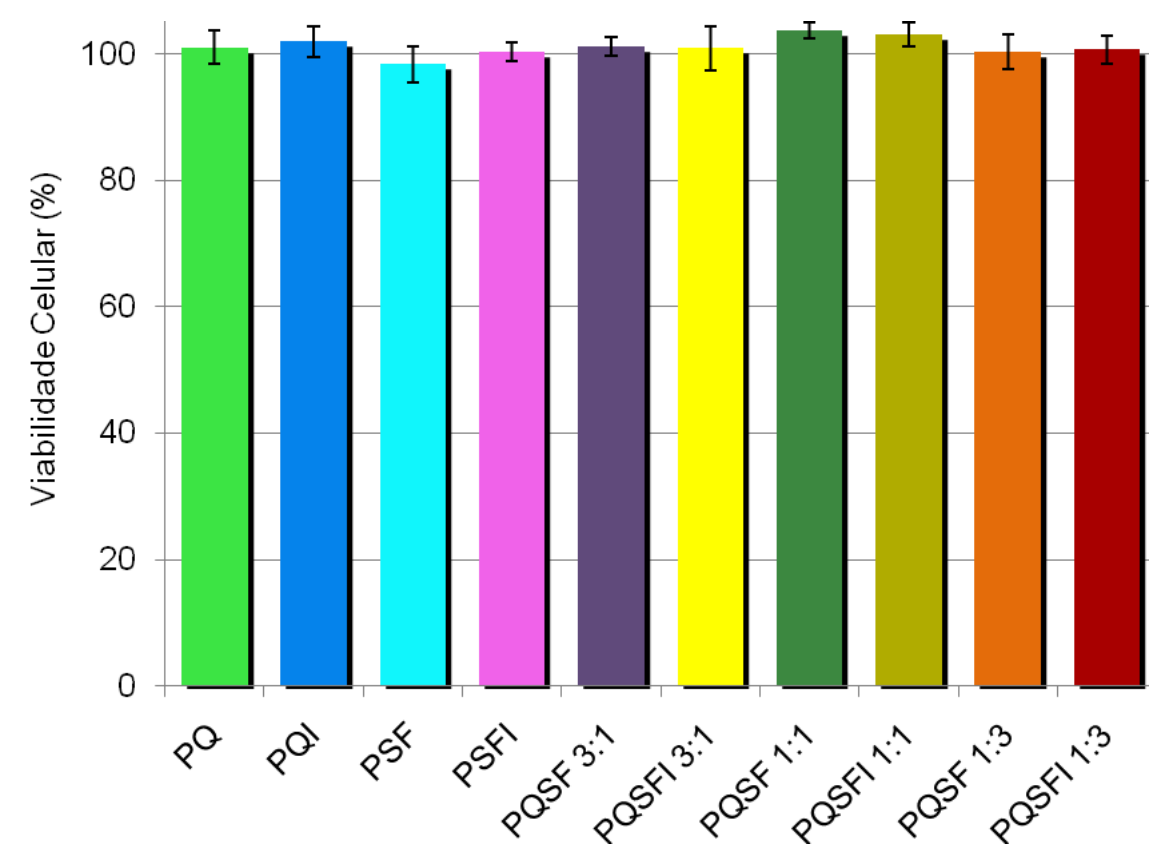

Figura 59. Viabilidade das células $\mathrm{CHO}(\%)$ nos extratos (100\%) do pericárdio bovino tratado com quitosana, fibroína de seda e misturas de quitosana/fibroína de seda, após lavagens. 


\subsubsection{Avaliação quanto à biofuncionalidade}

Membranas de PB tratadas com quitosana e fibroína de seda, com ou sem irradiação, foram analisadas quanto à biofuncionalidade.

As imagens abaixo mostram os resultados obtidos utilizando-se a microscopia confocal. Nas amostras de pericárdio bovino modificadas com as soluções puras de quitosana e fibroína de seda (Figuras 60 e 61), não foram observadas as células aderidas nas membranas irradiadas ou não irradiadas. Por outro lado, nas membranas modificadas com as misturas das duas soluções e irradiadas, podem ser observadas células aderidas e viáveis ao longo das fibras da estrutura do pericárdio bovino (Figuras 62, 63 e 64). A presença das fibras de Q e SF podem ser identificadas nos dois comprimentos de onda.

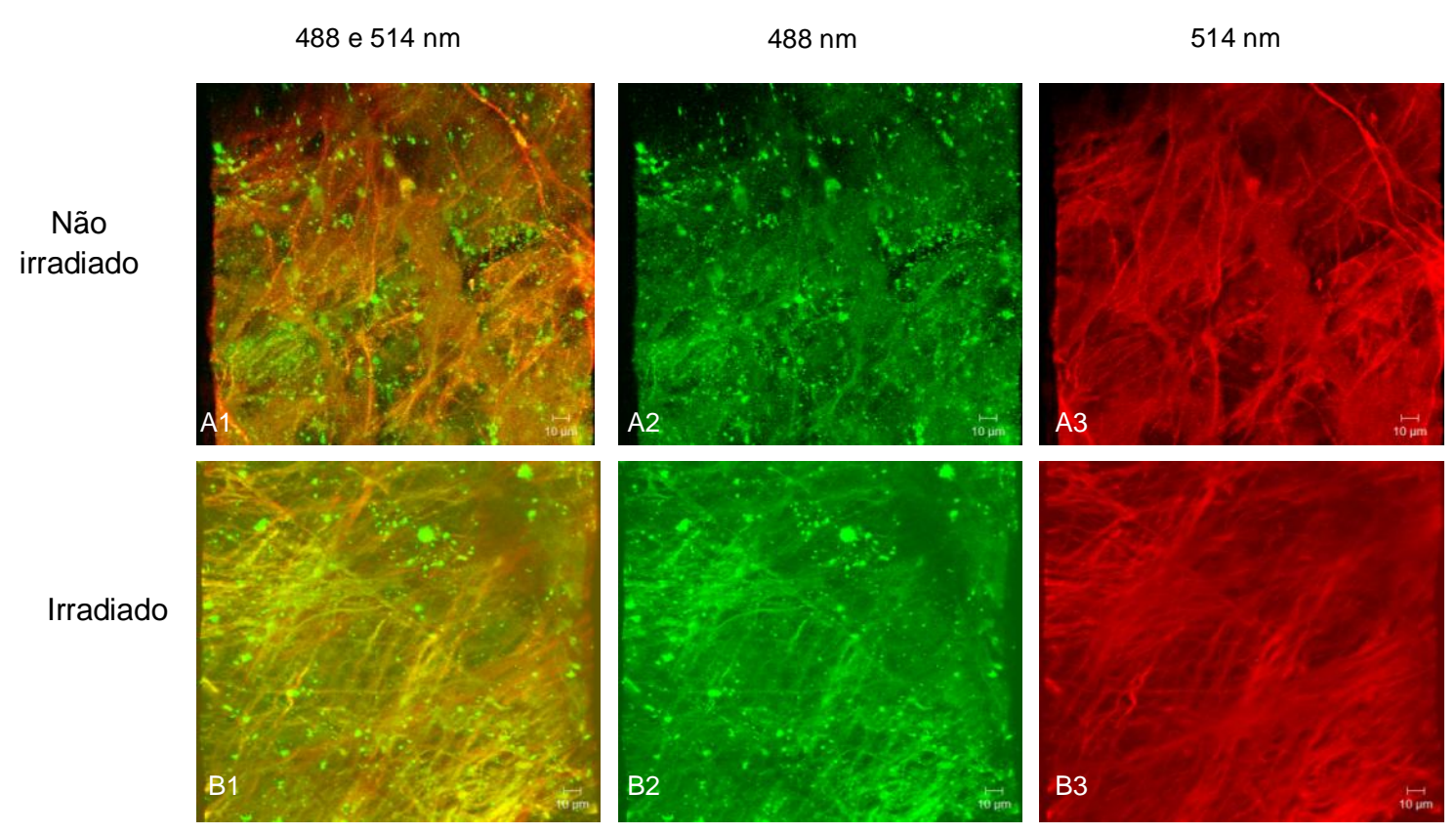

Figura 60. Imagens tridimensionais obtidas após o cultivo de células endoteliais no PQ não irradiado (superior) e irradiado (inferior). Todas as barras de escala em $10 \mu \mathrm{m}$. 
A partir destas imagens (Figura 60) podemos verificar que a solução de quitosana foi incorporada no tecido de PB liofilizado, e que sua presença inibe a adesão e a viabilidade celular. Podem ser observados pontos de afrouxamento das fibras de colágeno decorrentes da degradação exercida pelo ácido acético durante a incorporação da quitosana ao tecido.

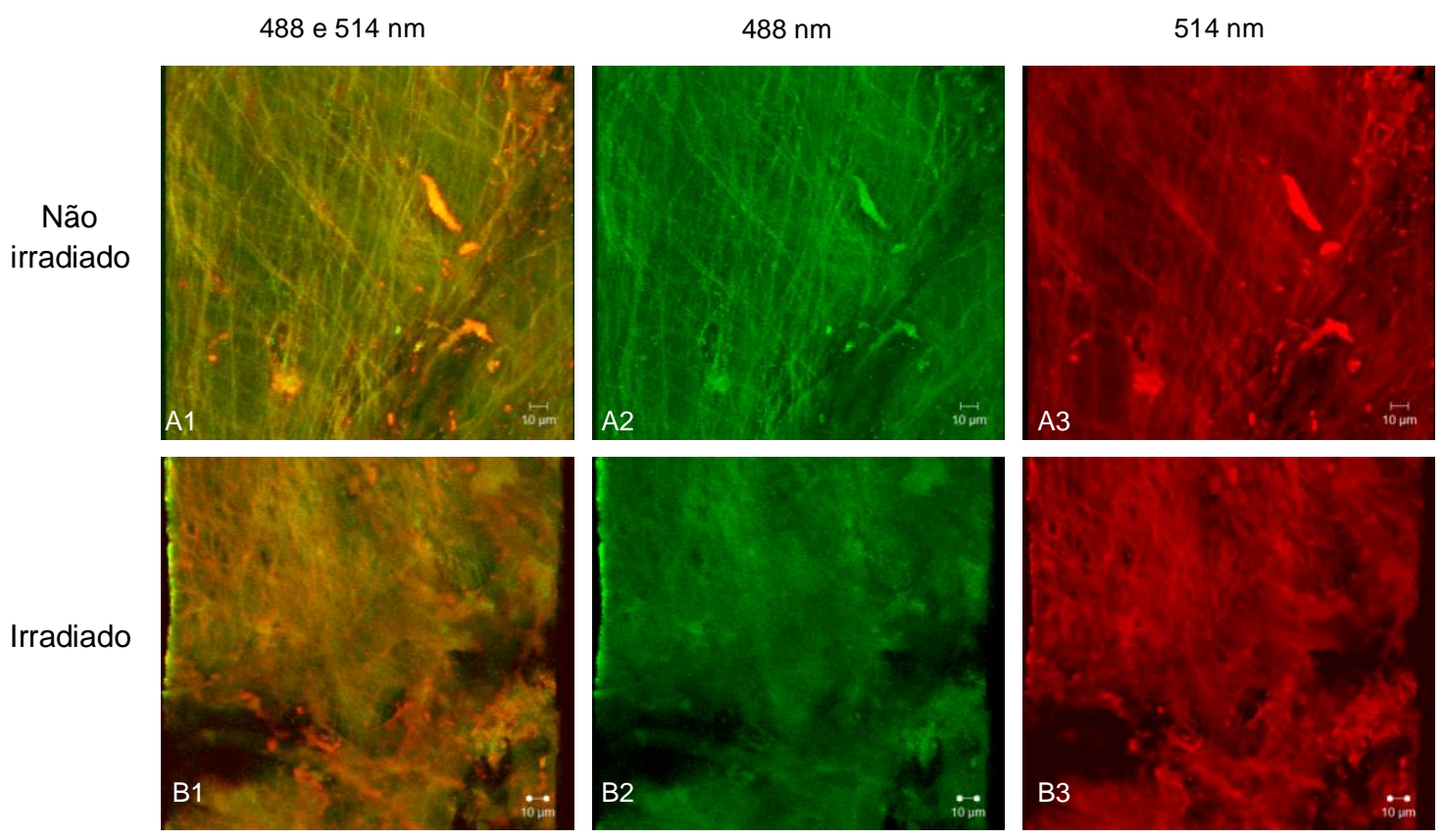

Figura 61. Imagens tridimensionais obtidas após o cultivo de células endoteliais no PSF não irradiado (superior) e irradiado (inferior). Todas as barras de escala em $10 \mu \mathrm{m}$.

A Figura 61 mostra as imagens obtidas a partir do cultivo de células no PSF irradiado e não irradiado. Conseguimos observar que a fibroína de seda desfavorece a adesão e viabilidade celular. Também pode-se notar alguns pontos de degradação no tecido, que pode ter ocorrido devido à irradiação. $\mathrm{Na}$ imagem superior é possível notar a presença de alguns grumos de SF que podem ter se aderido ao tecido durante a incorporação da solução.

As figuras 62-64 mostram as imagens tridimensionais obtidas a partir das amostras de PB incorporado às misturas de fibroína e quitosana em três diferentes proporções (1:3, 1:1 e 3:1). 


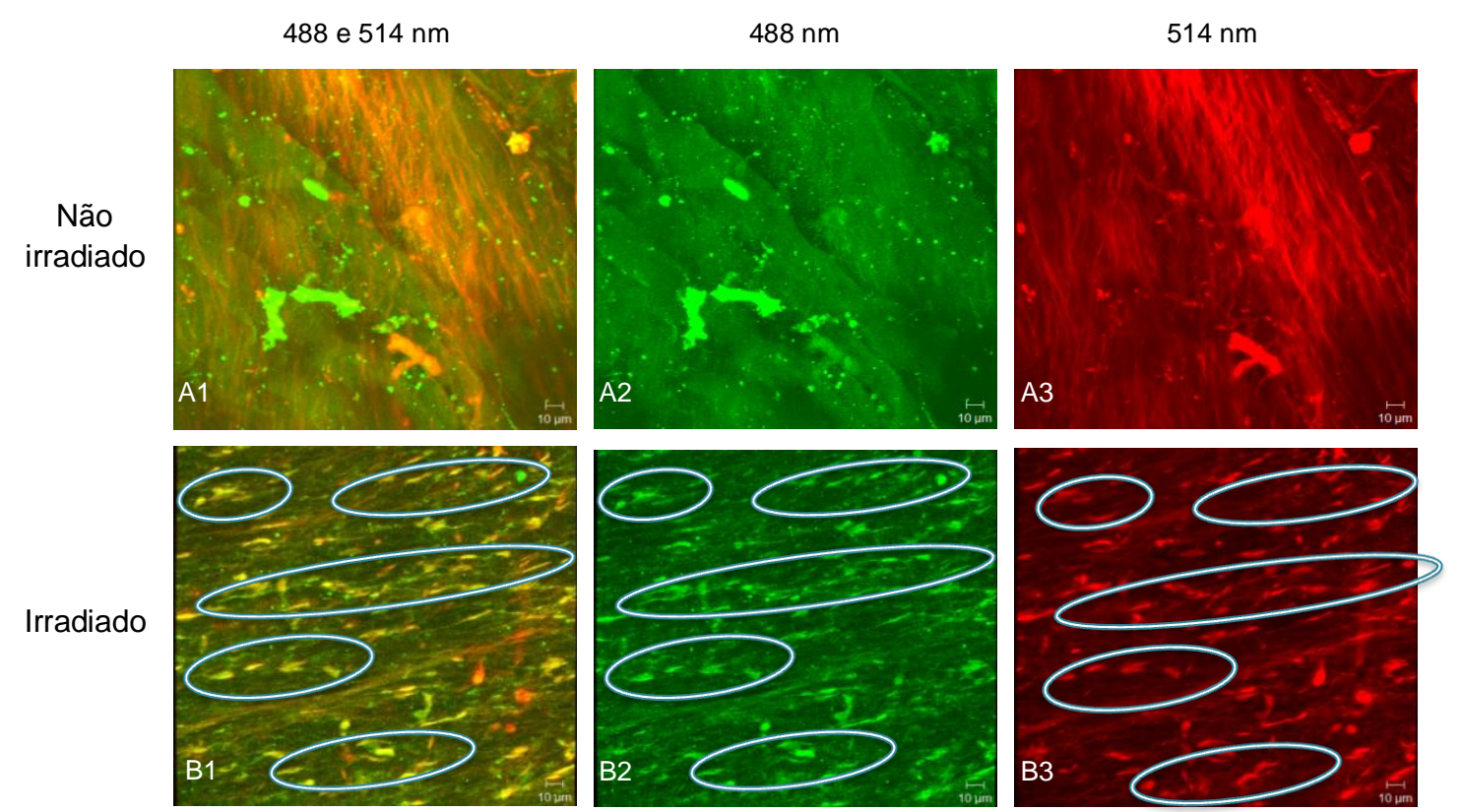

Figura 62. Imagens tridimensionais obtidas após o cultivo de células endoteliais no PQSF 3:1 não irradiado (superior) e irradiado (inferior). Os círculos indicam as células aderidas e viáveis no tecido. Todas as barras de escala em $10 \mu \mathrm{m}$.
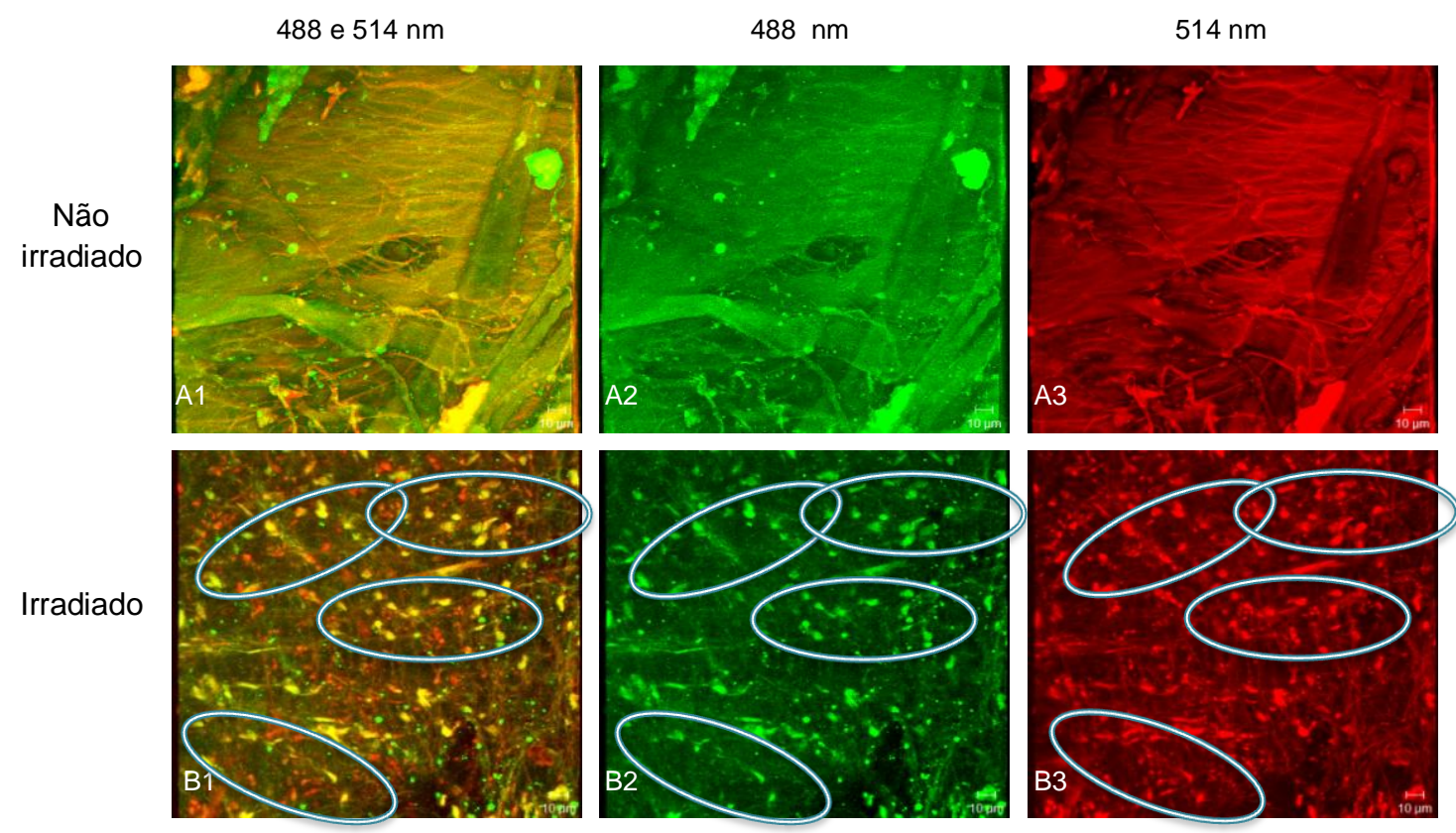

Figura 63. Imagens tridimensionais obtidas após o cultivo de células endoteliais no PQSF 1:1 não irradiado (superior) e irradiado (inferior). Os círculos indicam as células aderidas e viáveis no tecido. Todas as barras de escala em $10 \mu \mathrm{m}$. 


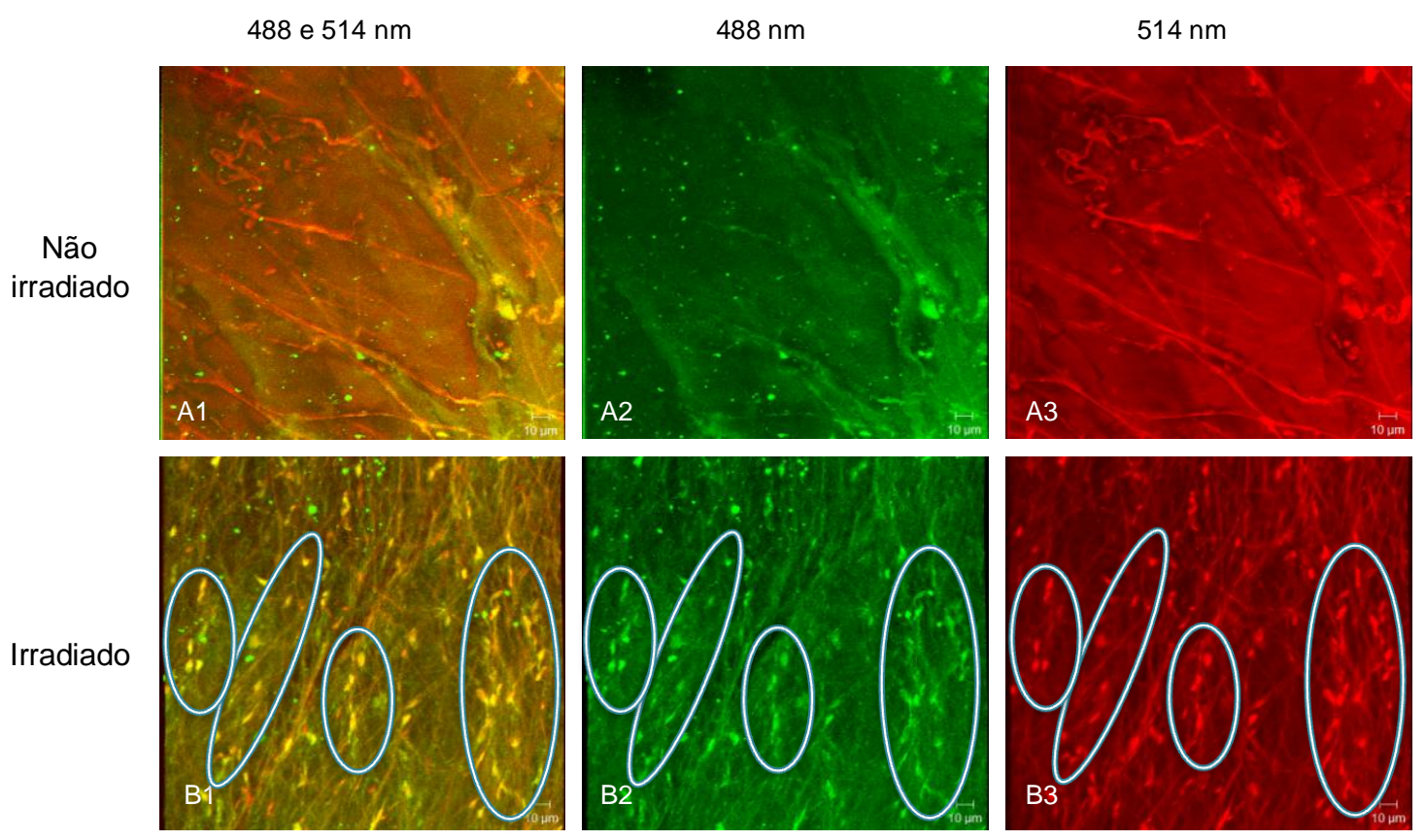

Figura 64. Imagens tridimensionais obtidas após o cultivo de células endoteliais no PQSF 1:3 não irradiado (superior) e irradiado (inferior). Os círculos indicam as células aderidas e viáveis no tecido. Todas as barras de escala em $10 \mu \mathrm{m}$.

Os resultados acima (Figuras 62-64) mostraram que as amostras de PQSF sem tratamento pela irradiação não apresentaram células aderidas. Nestas imagens conseguimos notar a presença de grumos de quitosana e/ou de fibroína que estao aderidos ao tecido. Tambem é possivel perceber a distribuição das misturas de QSF pelo tecido.

Após a irradiação das amostras PQSF (imagem inferior das figuras), para todas as proporções de misturas, nota-se que estas novas membranas favorecem a adesão e o crescimento de células endoteliais ao longo de todo 0 tecido (indicado por círculos). Estes resultados sugerem que a irradiação reorganiza as fibras do tecido de $\mathrm{PB}$ e/ou promove alterações entre as misturas (QSF) e as fibras de colágeno, e que estas alterações apresentam condições favoráveis para a adesão e crescimento das células endoteliais na matriz, pela 
preservação ou alteração (interação biologicamente favorável) dos sítios sinalizadores para a adesão das células endoteliais.

\subsubsection{Ensaios de calcificação in vitro}

Após realizar os ensaios de calcificação in vitro (Seção 4.19), as amostras foram analisadas por MEV e EDS (Figuras 65 - 75).Os resultados são mostrados a seguir.
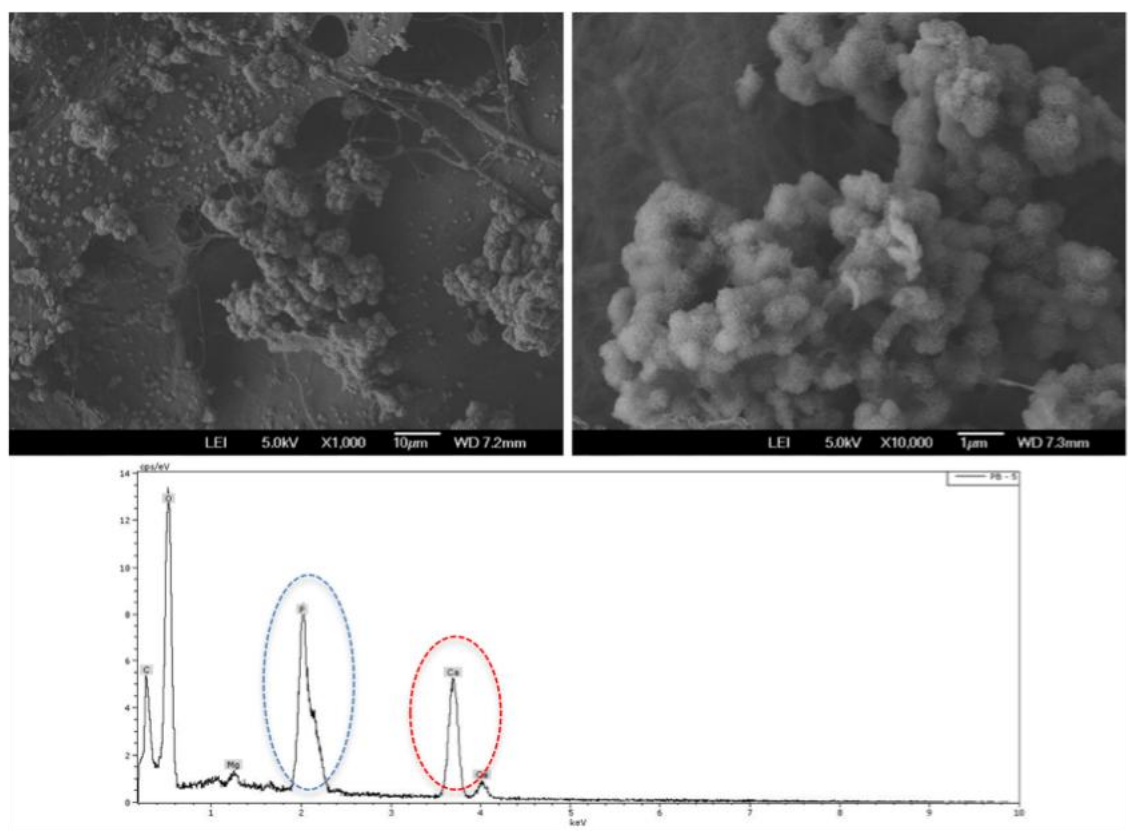

Figura 65. Imagens da superfície da amostra de PB obtidas por MEV (acima) e espectro gerado por EDS (abaixo) após ensaio de calcificação. Círculo azul = $\mathrm{P} ;$ círculo vermelho $=\mathrm{Ca}$. 

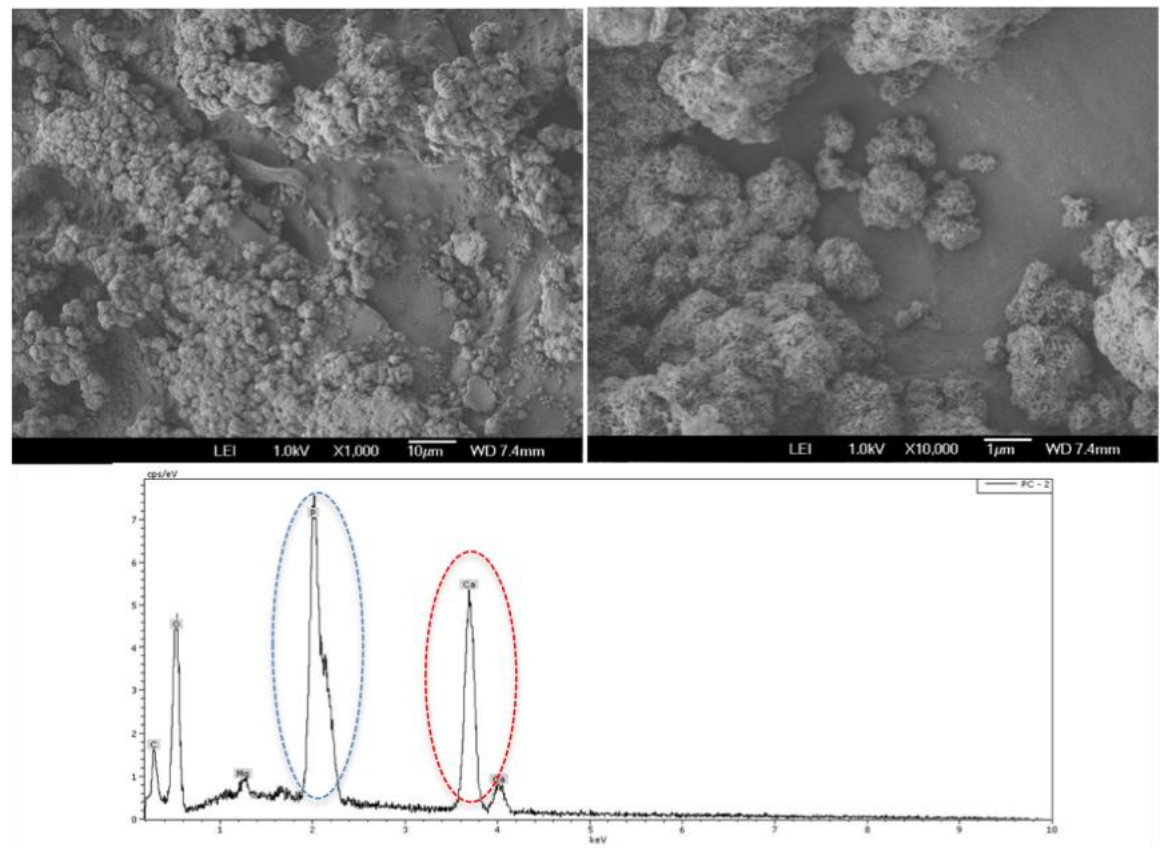

Figura 66. Imagens da superfície da amostra de PQ obtidas por MEV (acima) e espectro gerado por EDS (abaixo) após ensaio de calcificação. Círculo azul = $\mathrm{P}$; círculo vermelho = Ca.
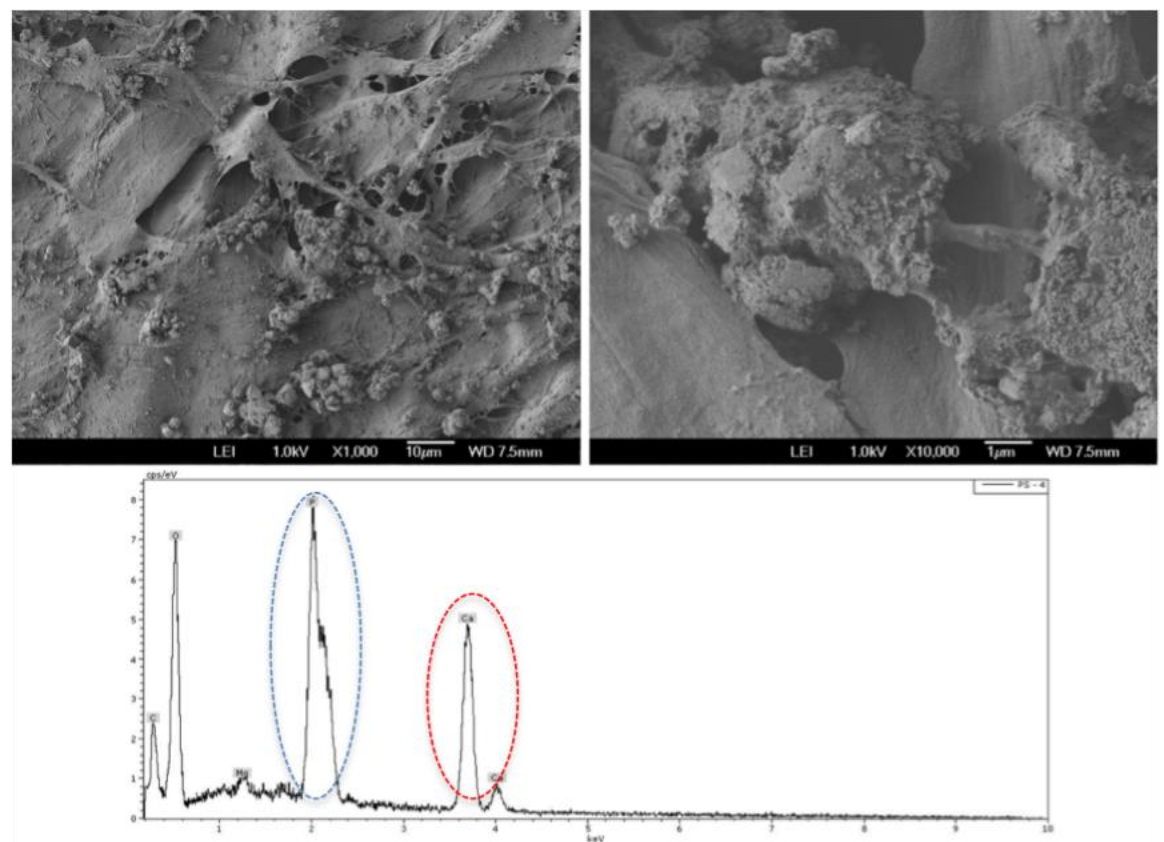

Figura 67. Imagens da superfície da amostra de PSF obtidas por MEV (acima) e espectro gerado por EDS (abaixo) após ensaio de calcificação. Círculo azul = $\mathrm{P} ;$ círculo vermelho $=\mathrm{Ca}$. 

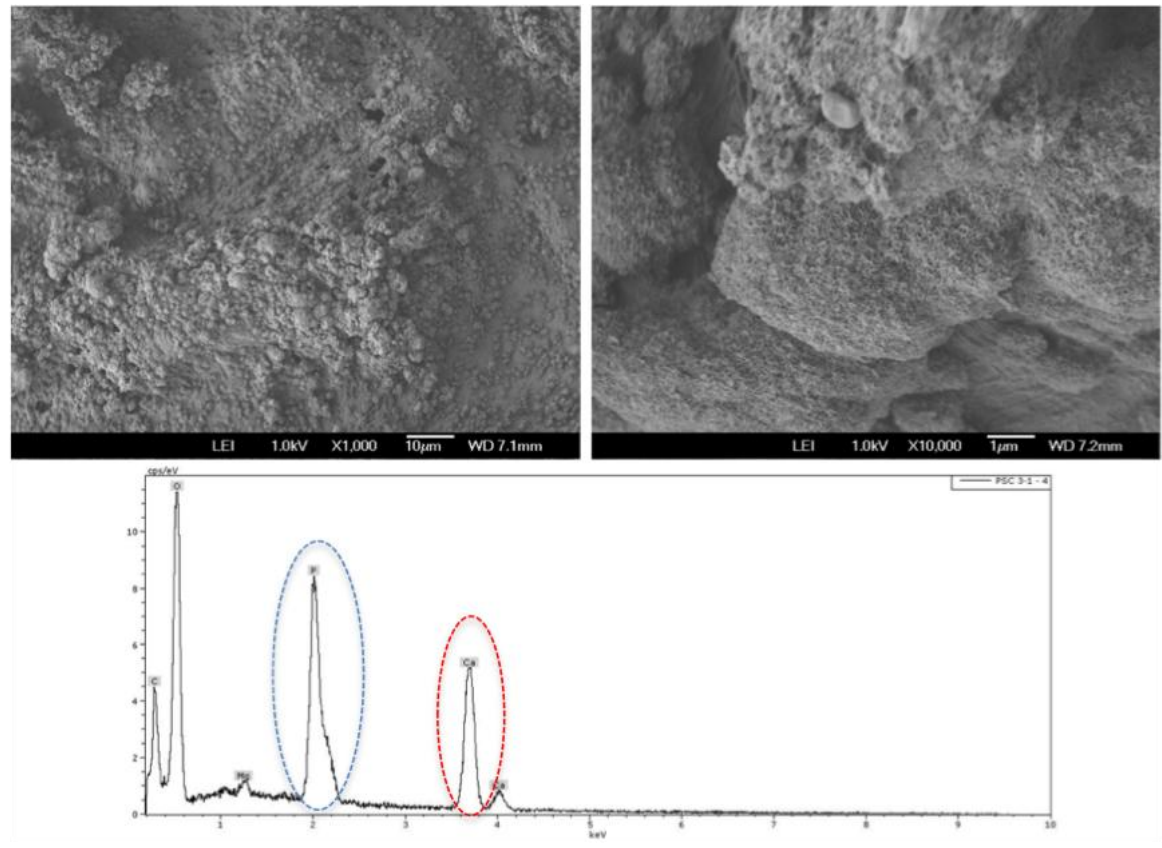

Figura 68. Imagens da superfície da amostra de PQSF 1:3 obtidas por MEV (acima) e espectro gerado por EDS (abaixo) após ensaio de calcificação. Círculo azul = P; círculo vermelho = Ca.
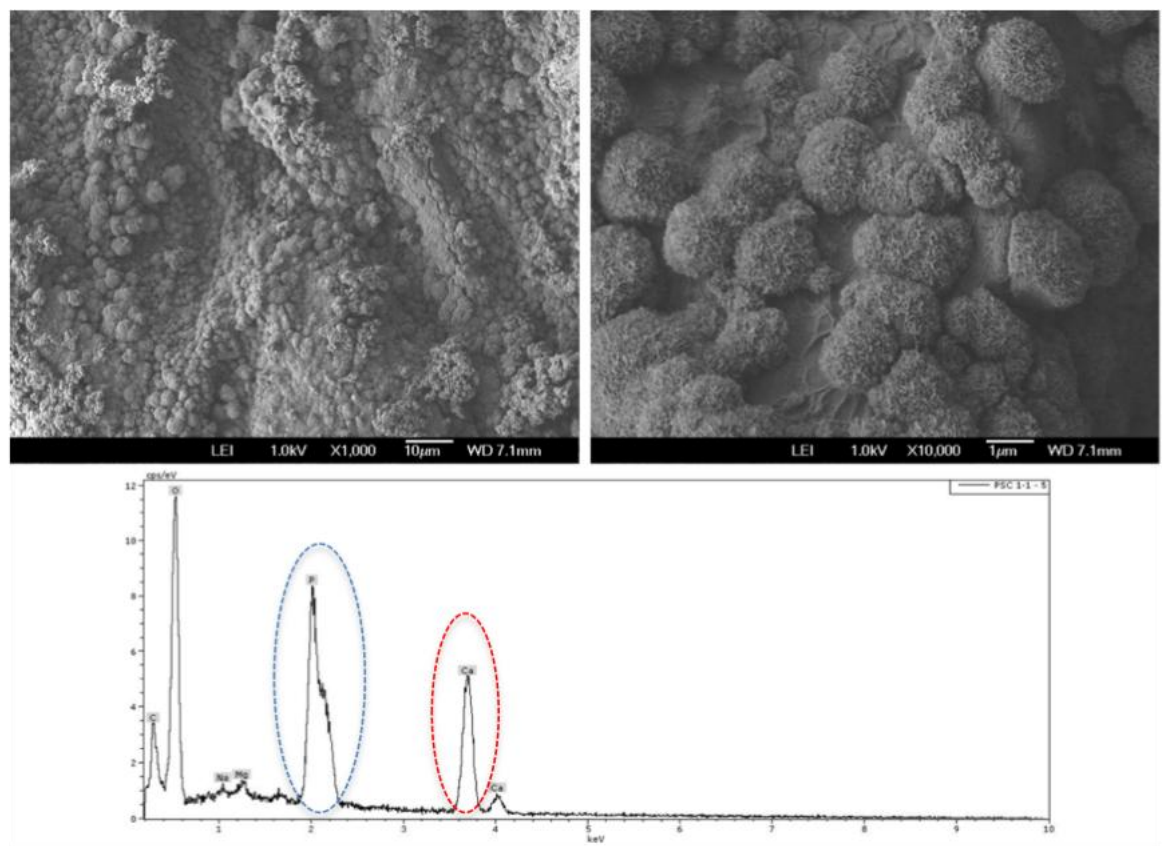

Figura 69. Imagens da superfície da amostra de PQSF 1:1 obtidas por MEV (acima) e espectro gerado por EDS (abaixo) após ensaio de calcificação. Círculo azul = P; círculo vermelho = Ca. 

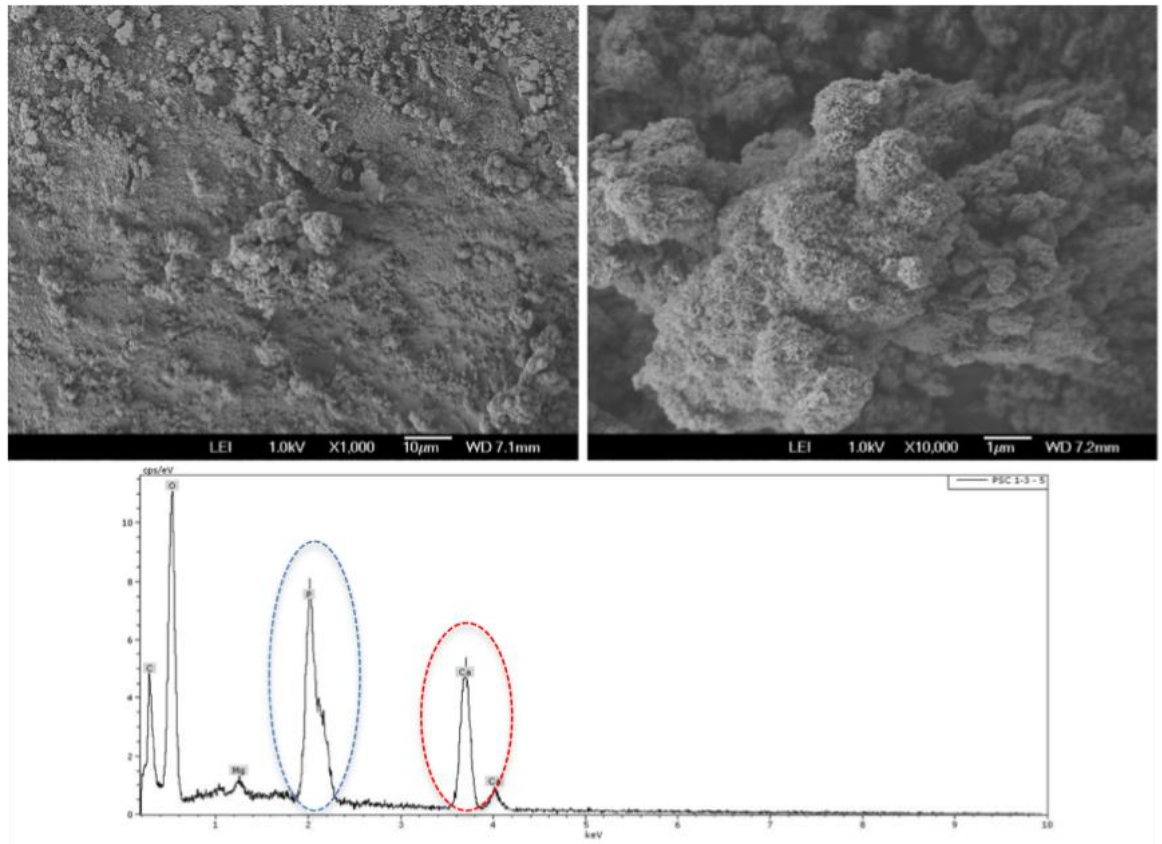

Figura 70. Imagens da superfície da amostra de PQSF 3:1 obtidas por MEV (acima) e espectro gerado por EDS (abaixo) após ensaio de calcificação. Círculo azul = P; círculo vermelho $=\mathrm{Ca}$.
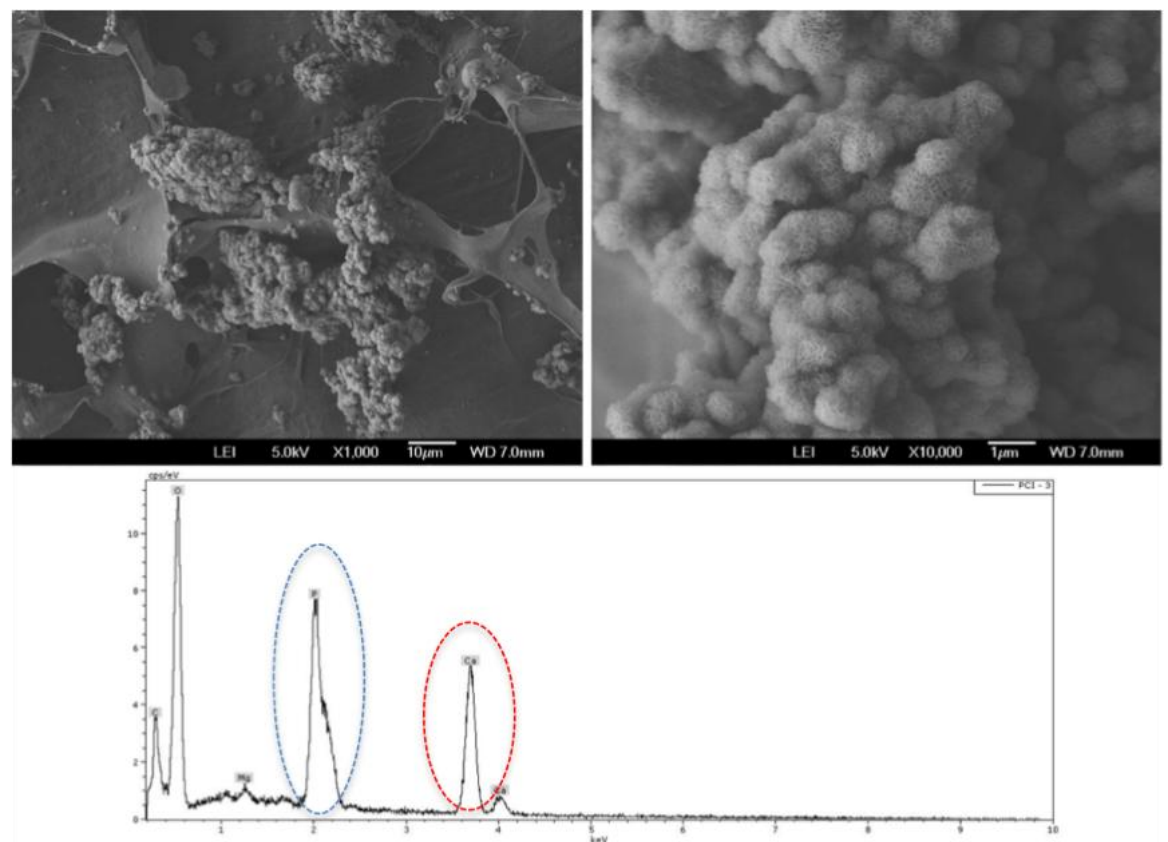

Figura 71. Imagens da superfície da amostra de PQI obtidas por MEV (acima) e espectro gerado por EDS (abaixo) após ensaio de calcificação. Círculo azul = $\mathrm{P}$; círculo vermelho $=\mathrm{Ca}$. 

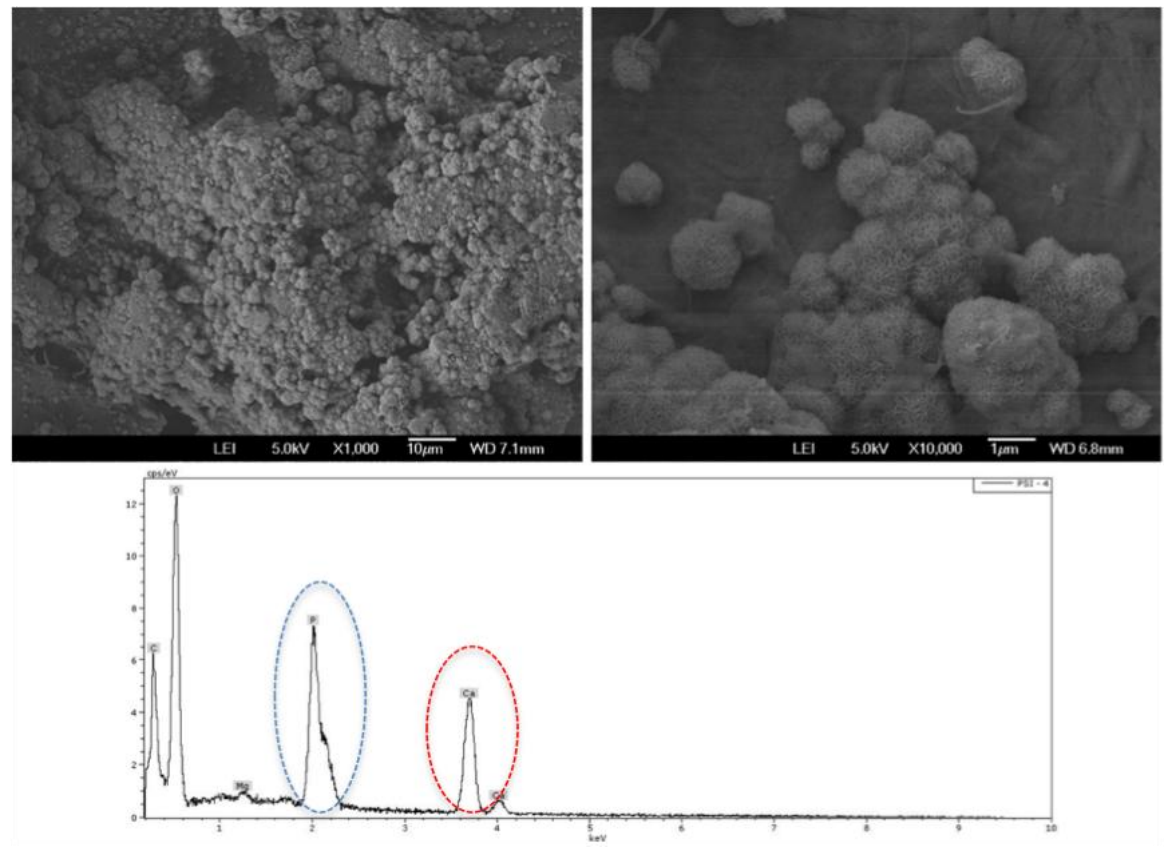

Figura 72. Imagens da superfície da amostra de PSFI obtidas por MEV (acima) e espectro gerado por EDS (abaixo) após ensaio de calcificação. Círculo azul = $\mathrm{P}$; círculo vermelho $=\mathrm{Ca}$.
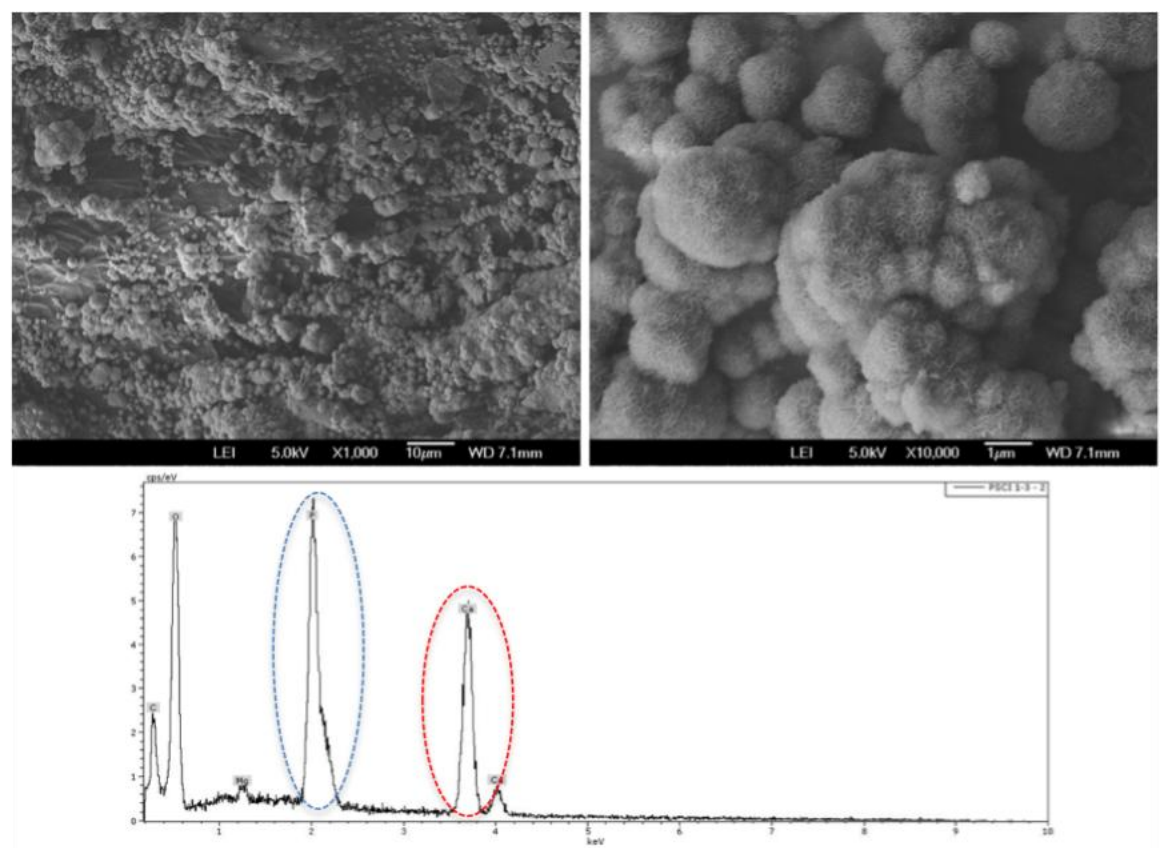

Figura 73. Imagens da superfície da amostra de PQSFI 3:1 obtidas por MEV (acima) e espectro gerado por EDS (abaixo) após ensaio de calcificação. Círculo azul = P; círculo vermelho $=\mathrm{Ca}$. 

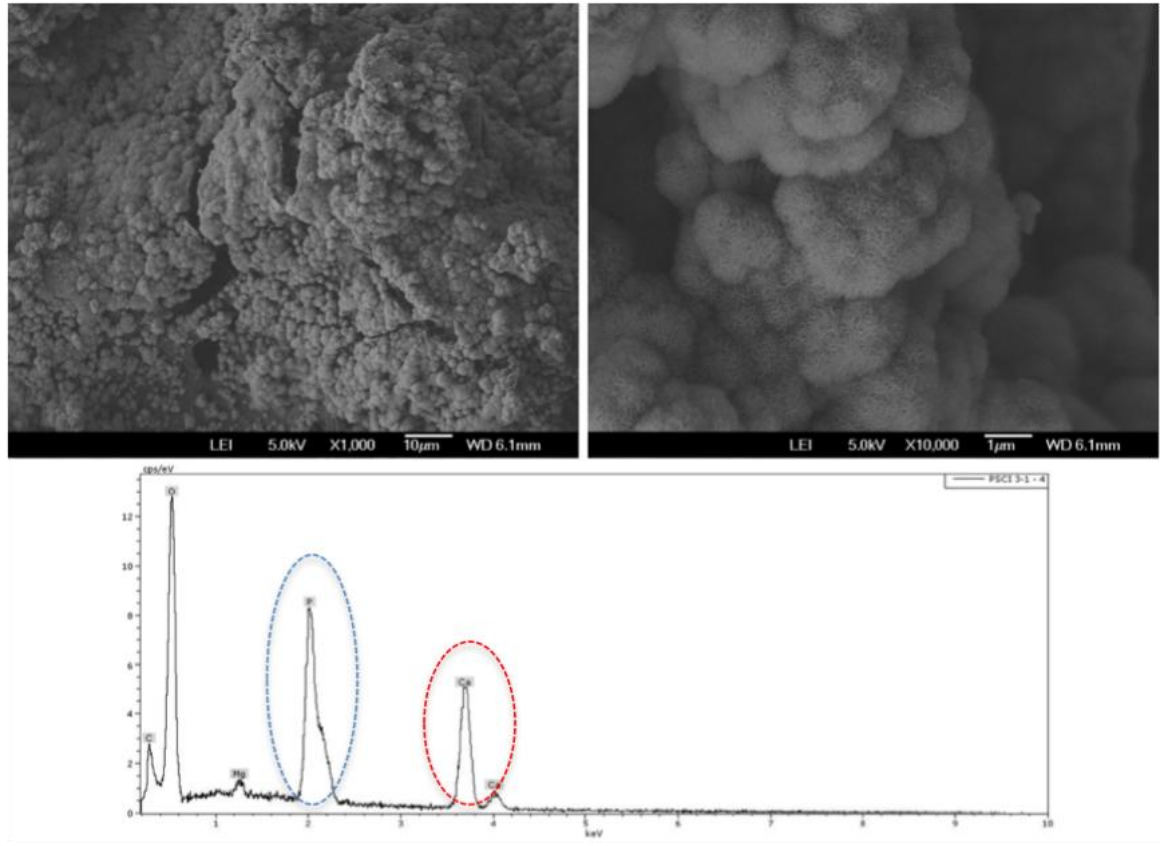

Figura 74. Imagens da superfície da amostra de PQSFI 1:3 obtidas por MEV (acima) e espectro gerado por EDS (abaixo) após ensaio de calcificação. Círculo azul = P; círculo vermelho $=\mathrm{Ca}$.
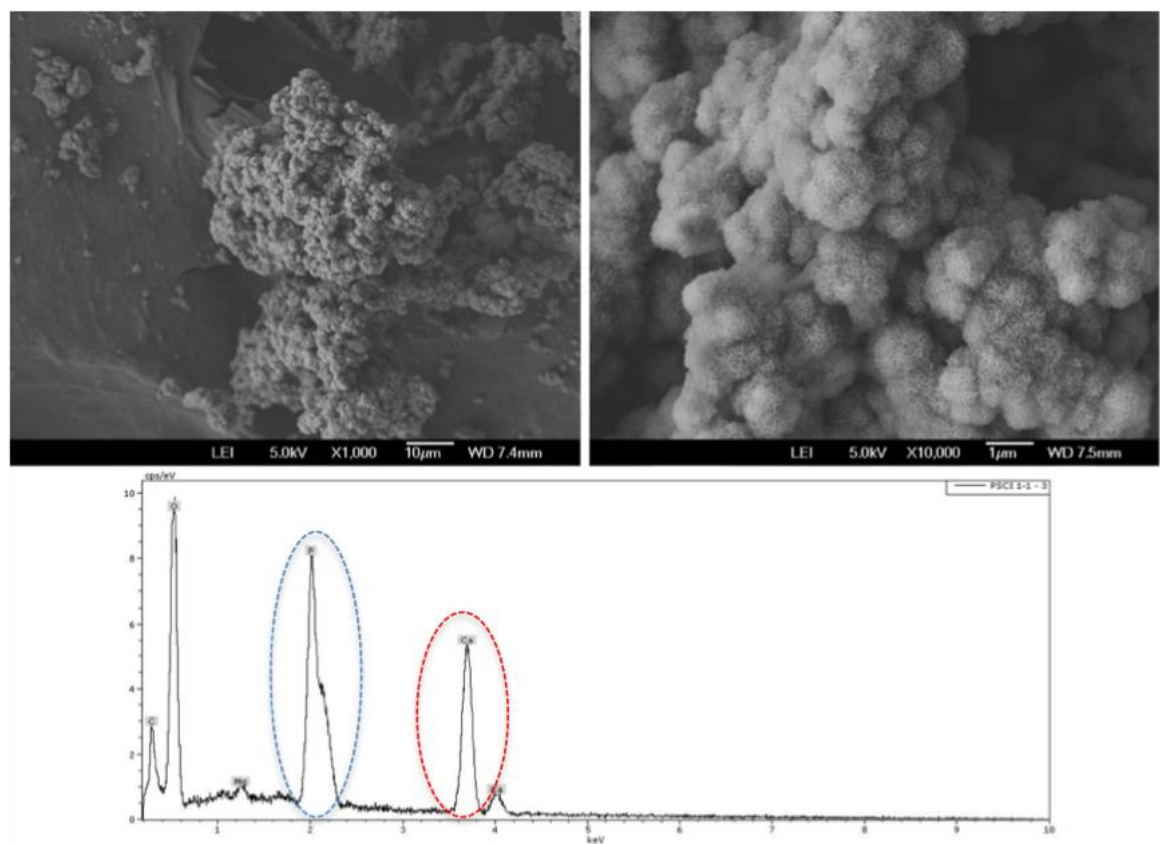

Figura 75. Imagens da superfície da amostra de PQSFI 1:1 obtidas por MEV (acima) e espectro gerado por EDS (abaixo) após ensaio de calcificação. Círculo azul = P; círculo vermelho = Ca. 
Como pode-se observar nas imagens captadas por MEV, todas as amostras tratadas com quitosana, fibroína de seda e suas misturas, mostraram depósitos esféricos na superfície das amostras. As amostras que sofreram irradiação também induziram a calcificaram.

Duarante todo o teste, a cada troca de solução de SBF e ao fim dos testes, o pH das soluções foi medido. $\mathrm{O} \mathrm{pH}$ de todas as soluções foi aumentado, o que é um indício de calcificação (BEPPU, 1999). Além disso o $\mathrm{pH}$ mostra que as amostras não estavam contaminadas, exceto uma das amostras de PB sem tratamento que mostrou uma queda do $\mathrm{pH}$ para 7,3, indicando uma possível contaminação microbiana.

A natureza dos depósitos foram confirmadas por análises de EDS, confirmando-se a presença de $\mathrm{Ca}$ e de $\mathrm{P}$ nas formações. $\mathrm{A}$ análise por EDS nos permite obter a relação molar de cálcio e fósforo nas amostras $(\mathrm{Ca} / \mathrm{P})$. Em todas as amostras (Figuras 65-75) o Ca e P estão presentes e o cálculo da relação molar de $\mathrm{Ca} / \mathrm{P}$ para cada amostra pode ser observada na Tabela 10. Esta relação atômica nos permite verificar o tipo de depósitos que estão sendo formados na amostra. Normalmente, o principal tipo de formação investigada é a da hidroxiapatita (HA). A HA apresenta uma relação de $\mathrm{Ca} / \mathrm{P}$ de 1,67 (MIKROULIS et al., 2002). Entretanto, as amostras analisadas apresentaram uma relação $\mathrm{Ca} / \mathrm{P}$ menor do que 1,67 , indicando portanto que outro tipo de calcificação estava sendo formado e não HA.

Algumas amostras apresentaram formas esféricas mais irregulares (PQSF 3:1, PQSF 1:3 e PSF, por exemplo) e outras mais regulares e homogêneos (PQSFI em todas as proporções, por exemplo), sugerindo mecanismos de deposição diferentes (BEPPU; SANTANA, 2002). 
Tabela 10. Valores da relação $\mathrm{Ca} / \mathrm{P}$ obtidos por EDS.

\begin{tabular}{c|c}
\hline Amostra & Média* $(\mathbf{C a} / \mathbf{P})^{\text {PB }}$ \\
PQ & $1,31 \pm 0,08$ \\
PSF & $1,27 \pm 0,20$ \\
PQSF 3:1 & $0,99 \pm 0,23$ \\
PQSF 1:3 & $1,24 \pm 0,20$ \\
PQSF 1:1 & $1,38 \pm 0,07$ \\
PQI & $1,04 \pm 0,11$ \\
PSFI & $1,28 \pm 0,03$ \\
PQSFI 3:1 & $1,41 \pm 0,17$ \\
PQSF 1:3 & $1,31 \pm 0,04$ \\
PQSF 1:1 & $1,29 \pm 0,07$ \\
\hline
\end{tabular}

* Média de cinco valores $(\mathrm{n}=5)$. 


\section{CONCLUSÕES}

- A irradiação do tecido na presença de oxigênio favorece a cisão das cadeias de colágeno. Entretanto, na ausência de oxigênio, utilizando-se os mesmos parâmetros de irradiação, foi possível notar que o tecido sofre preferencialmente reticulação;

- As taxas de dose aplicadas durante a irradiação é um parâmetro importante, pois sugere que a menor taxa aplicada favorece maior taxa de reticulação;

- O módulo de elasticidade é diminuído quando amostras de PB são irradiadas tanto na presença quanto na ausência de oxigênio;

- O teste de biofuncionalidade sugere que os tecidos irradiados favorecem a adesão e crescimento de células endoteliais;

- Não foram observadas alterações estruturais significativas através da Espectroscopia Raman para as amostras modificadas com Q e SF;

- Todas as amostras apresentam toxicidade na concentração do extrato de $100 \%$. Entretanto após algumas lavagens é possível verificar que os resíduos são removidos;

- Os testes de biofuncionalidade sugerem que as amostras de PQSFI (todas as proporções) favorecem a adesão e crescimento das células endoteliais;

- Todas as amostras induziram a calcificação, mas apresentaram uma relação $\mathrm{Ca} / \mathrm{P}$ menor do que a da $\mathrm{HA}$;

- As amostras PQSFI (todas as proporções) afinidade pelas células endoteliais. Esta camada de células poderia ajudar a manter a integridade da válvula, além de melhorar suas propriedades mecânicas e ajudar a evitar a calcificação. 


\section{PROPOSTAS PARA TRABALHOS FUTUROS}

- Estudar a calcificação in vitro após realizar o crescimento de células endoteliais in vitro;

- Realizar ensaios de punção após os ensaios de adesão e crescimento celular in vitro;

- Estudar a cultura de células endoteliais in vitro em membranas de PB recobertas por layer-by-layer (filmes multicamadas) com as soluções de quitosana e fibroína de seda, para verificar se com um melhor alinhamento destes biopolímeros na superfície do tecido de PB a adesão e crescimento de células é favorecido. 


\section{REFERÊNCIAS BIBLIOGRÁFICAS}

ABDELWAHED, W.; DEOGOBERT, G.; FESSI, H. Freeze-drying of nanocapsules: impact of annealing on the drying process. International Journal of Pharmaceutics, v.324, n.1, p.74-82, 2006.

ABOLHODA, A.; YU, S.; OYARZUN, J.R.; MCCORMICK, J.R.; BOGDEN, J.D.; GABBAY, S. Calcification of bovine pericardium: glutaraldehyde versus no-react biomodification. Annals of Thoracic Surgery, v.62, n.1, p.169-174, 1996.

AIMOLI, C.G.; NOGUEIRA, G.M.; NASCIMENTO, L.S.; BACETI, A.; LEIRNER, A.A.; MAIZATO, M.J.S.; HIGA, O.Z.; POLAKIEWICZ, B.; PITOMBO, R.N.M.; BEPPU M.M. Lyophilized bovine pericardium treated with a phenethylaminediepoxide as an alternative to preventing calcification of cardiovascular bioprosthesis: preliminary calcification results. Artificial Organs, v.31, n.4, p.278283, 2007.

ALTMAN, A.M.; GUPTA, V.; RÍOS, C.N. Adhesion, migration and mechanics of human adipose-tissue-derived stem cells on silk fibroin-chitosan matrix. Acta Biomaterialia, v.6, n.4, p.1388-1397, 2010.

ALTMAN, G.H.; DIAZ, F.; JAKUBA, C.; CALABRO, T.; HORAN, R.L.; CHEN, J.; LU, H.; RICHMOND, J.; KAPLAN, D.L. Silk-based biomaterials. Biomaterials, v.24, n.3, p.401-416, 2003.

ARCIDIACONO, G.; CORVI, A.; SEVERI, T. Functional analysis of bioprosthetic heart valves. Journal of Biomechanics, v.38, n.7, p.1483-1490, 2005.

BAILEY, A.J.; TROMANS, W.J. Effects of ionizing radiation on the ultrastructure of collagen fibrils. Radiation Research, v.23, n.1, p.145-155, 1964.

BATISTA, T.M.; MARTINS, V.C.A.; PLEPIS, A.M.G. Thermal behavior of in vitro mineralized anionic collagen matrices. Journal of Thermal Analysis and Calorimetry, v.95, n.3, p.945-949, 2009. 
BAUCIA, J.A.; LEAL NETO, R.M.; ROGERO, J.R.; NASCIMENTO, N.; REYES, C.A.C. Effects of gamma irradiation on mechanical behavior and calcification of glutaraldehyde-fixed bovine pericardium. Brazilian Journal of Cardiovascular Surgery, v.22, n.1, p.75-80, 2007.

BEPPU, M.M. Estudo da calcificação in vitro de quitosana. Campinas, 1999. 125p. Tese de Doutorado - Faculdade de Engenharia Química, Universidade de Campinas.

BEPPU, M.M.; SANTANA, C.C. Influence of calcification solution on in vitro chitosan mineralization. Materials Research, v.5, n.1, p.47-50, 2002.

BORGOGNONI, C.F.; TATTINI JR., V.; AYROSA, A.M.I.B.; POLAKIEWICZ, B.; LEIRNER, A.A.; MAIZATO, M.J.S.; HIGA, O.Z.; BEPPU, M.M.; PITOMBO, R.N.M. The Influence of Freezing Rates on Bovine Pericardium Tissue FreezeDrying. Brazilian Archives of Biology and Technology, v.52, n.6, p. 1493-1504, 2009.

BUTLER, J.; LAND, E.J.; PRÜTZ, W.A.; SWALLOW, A.J. Charge transfer between tryptophan and tyrosine in proteins. Biochimica et Biophysica Acta, v.705, n.2, p.150-162, 1982.

CAMERON, P., ed. Good pharmaceutical freeze-drying practice. Buffalo Grove: Interpharm, 1997. 303p.

CHAPIRO, A. Radiation chemistry of polymeric systems. New York, London: Interscience, 1962. 732p. (High polymers, v.15).

CHEN, X.; KNIGHT, D.P.; SHAO, Z.; VOLLRATH, F. Regenerated Bombyx silk solutions studied with rheometry and FTIR. Polymer, v.42, n.25, p.9969-9974, 2001.

CHEN, X.; LI, W.; YU, T. Conformation transition of silk fibroin induced by blending chitosan. Journal of Polymer Science: Part B: Polymer Physics, v.35, n.14, p.2293-2296, 1997. 
CONNOLLY, J.M.; ALFERIEV, I.; CLARK-GRUEL, J.N.; EIDELMAN, N.; SACKS, M.; PALMATORY, E.; KRONSTEINER, A.; DEFELICE, S.; XU, J.; OHRI, R.; NARULA, N.; VYAVAHARE, N.; LEVY, R.J. Triglycidylamine crosslinking of porcine aortic valve cusps or bovine pericardium: results in improved biocompatibility, biomechanics, and calcification resistance: chemical and biological mechanisms. American Journal of Pathology, v.166, n.1, p.1-13, 2005.

CORY, A.H.; OWEN, T.C.; BARLTROP, J.A.; CORY J.G. Use of an aqueous soluble tetrazolium/formazan assay for cell growth assays in culture. Cancer Communications, v.3, p.207-212, 1991.

COSGROVE, D.M.; LYTLE, B.W.; GILL, C.C.; GOLDING, L.A.; STEWART, R.W.; LOOP, F.D.; WILLIAMS, G.W. In vivo hemodynamic comparison of porcine and pericardial valves. Journal of Thoracic and Cardiovascular Surgery, v.89, n.3, p.358-368, 1985.

COSTA, F.D.A.; DOHMEN, P.M.; LOPES, S.V.; LACERDA, G.; POHL, F.; VILANI, R.; COSTA, M.B.A.; VIEIRA, E.D.; YOSCHI, S.; KONERTZ, W.; COSTA, I.A. Comparison of cryopreserved homografts and decellularized porcine heterografts implanted in sheep. Artificial Organs, v.28, n.4, p.366-370, 2004.

DAAR, E.; WOODS, E.; KEDDIE, J.L.; NISBET, A.; BRADLEY, D.A. Effect of penetrating ionizing radiation on the mechanical properties of pericardium. Nuclear Instruments \& Methods in Physics Research, Section A, 2009. [No Prelo].

DOENST, T.; BORGER, M.A.; DAVID, T.E. Long-term results of bioprosthetic mitral valve replacement the pericardial perspective. Journal of Cardiovascular Surgery, v.45, n.5, p.449-454, 2004.

DORNISH, M.; KAPLAN, D.; SKAUGRUD, O. Standards and guidelines for biopolymers in tissue-engineered medical products: ASTM alginate and 
chitosan standard guides. Annals of the New York Academy of Sciences, v.944, p.388-397, 2001.

EHRENSTEIN, G.W.; RIEDEL, G.; TRAWIEL, P. Thermal analysis of plastics: theory and practice. Munich: Hanser, 2004. 368p.

FEUGIER, P.; BLACK, R.A.; HUNT, J.A.; HOW, T.V. Attachment, morphology and adherence of human endothelial cells to vascular prosthesis materials under the action of shear stress. Biomaterials, v.26, n.13, p.1457-1466, 2005.

FREDDI, G.; PESSINA, G.; TSUKADA, M. Swelling and dissolution of silk fibroin (Bombyx mori) in $\mathrm{N}$-methyl morpholine $\mathrm{N}$-oxide. International Journal of Biological Macromolecules, v.24, n.2/3, p.251-263, 1999.

FRIESS, W. Collagen-biomaterial for drug delivery. European Journal of Pharmaceutics and Biopharmaceutics, v.45, n.2, p.113-136, 1998.

FRUSHOUR, B.G.; KOENIG, J.L. Raman spectroscopic study of mechanically deformed poly-l-alanine. Biopolymers, v.13, n.3, p.455-474, 1974.

FUCHS, S.; MOTTA, A.; MIGLIARESI, C.; KIRKPATRICK, C.J. Outgrowth endothelial cells isolated and expanded from human peripheral blood progenitor cells as a potential source of autologous cells for endothelialization of silk fibroin biomaterials. Biomaterials, v.27, n.31, p.5399-5408, 2006.

GENDLER, E.; GENDLER, S.; NIMNI, M.E. Toxic reactions evoked by glutaraldehyde-fixed pericardium and cardiac valve tissue bioprosthesis. Journal of Biomedical Materials Research, v.18, n.7, p.727-736, 1984.

GOBIN, A.S.; FROUDE, V.E.; MATHUR, A.B. Structural and mechanical characteristics of silk fibroin and chitosan blend scaffolds for tissue regeneration. Journal of Biomedical Materials Research, Part A, v.74, n.3, p.465-473, 2005.

GRAUSSA, R.W.; HAZEKAMPB, M.G.; OPPENHUIZENA, F.; VAN MUNSTERENA, C.J.; GITTENBERGER-DE GROOTA, A.C.; DERUITERA, 
M.C. Histological evaluation of decellularised porcine aortic valves: matrix changes due to different decellularisation methods. European Journal of CardioThoracic Surgery, v.27, n.4, p.566-571, 2005.

GULBINS, H.; PRITISANAC, A.; PIEPER, K.; GOLDEMUND, A.; MEISER, B.M.; REICHART, B.; DAEBRITZ, S. Successful endothelialization of porcine glutaraldehyde-fixed aortic valves in a heterotopic sheep model. Annals of Thoracic Surgery, v.81, n.4, p.1472-1479, 2006.

GUPTA, M.K.; KHOKHAR, S.K.; PHILLIPS, D.M.; SOWARDS, L.A.; DRUMMY, L.F.; KADAKIA, M.P.; NAIK, R.R. Patterned silk films cast from ionic liquid solubilized fibroin as scaffolds for cell growth. Langmuir, v.23, n.3, p.1315-1319, 2007.

HAFEEZ, Y.M.; ZUKI, A.B.Z.; YUSOF, N.; ASNAH, H.; LOQMAN, M.Y.; NOORDIN, M.M.; AINUL-YUZAIRI, M.Y. Effect of freeze-drying and gamma irradiation on biomechanical properties of bovine pericardium. Cell and Tissue Banking, v.6, n.2, p.85-89, 2005.

HAWE, A.; FRIESS, W. Impact of freezing procedure and annealing on the physico-chemical properties and the formation of mannitol hydrate in mannitolsucrose- $\mathrm{NaCl}$ formulations. European Journal of Pharmaceutics and Biopharmaceutics, v.64, n.3, p.316-325, 2006.

HU, K.; CUI, F.; LV, Q.; MA, J.; FENG, Q.; XU, L.; FAN, D. Preparation of fibroin/recombinant human-like collagen scaffold to promote fibroblasts compatibility. Journal of Biomedical Materials Research, Part A, v.84, n.2, p.483-490, 2008.

INTERNATIONAL ORGANIZATION FOR STANDARDIZATION. ISO 10993-5: biological testing of medical and dental materials devices. Part 5: tests for cytotoxicity: in vitro methods. Geneva, 1992. 33p. 
INTERNATIONAL ORGANIZATION FOR STANDARDIZATION. ISO 10993-5: biological testing of medical and dental materials devices. Part 5: tests for cytotoxicity: in vitro methods. Geneva, 2009. 33p.

JAFFE, E.A.; HOYER, L.W.; NACHMAN, R.L. Synthesis of antihemophilic factor antigen by cultured human endothelial cells. Journal of Clinical Investigation, v.52, n.11, p.2757-2764, 1973.

JASTRZEBSKA, M.; ZALEWSKA-REJDAK, J.; WRZALIK, R.; KOCOT, A.; BARWIN'SKI, B.; MRÓZ, I.; CWALINA, B. Dimethyl suberimidate cross-linked pericardium tissue: raman spectroscopic and atomic force microscopy investigations. Journal of Molecular Structure, v.744/747, p.789-795, 2005.

JIANG, B.; WU, Z.; ZHAO, H.; TANG, F.; LU, J.; WEI, Q.; ZHANG, X. Electron beam irradiation modification of collagen membrane. Biomaterials, v.27, n.1, p.15-23, 2006.

JORGE-HERRERO, E.; GARCÍA PÁEZ, J.M.; DEL CASTILLO-OLIVARES RAMOS, J.L. Tissue heart valve mineralization: review of calcification mechanisms and strategies for prevention. Journal of Applied Biomaterials \& Biomechanics, v.3, n.2, p.67-82, 2005.

KANTI, P.; SRIGOWRI, J.; MADHURI, J.; SMITHA, B.; SRIDHAR, S. Dehydration of ethanol through blend membranes of chitosan and sodium alginate by pervaporation. Separation and Purification Technology, v.40, n.3, p.259-266, 2004.

KASIMIR, M.T.; WEIGEL, G.; SHARMA, J.; RIEDER, E.; SEEBACHER, G.; WOLNER, E.; SIMON, P. The decellularized porcine heart valve matrix in tissue engineering: platelet adhesion and activation. Thrombosis and Haemostasis, v.94, n.3, p.562-567, 2005.

KHOR, E. Chitin: a biomaterial in waiting. Current Opinion in Solid State \& Materials Science, v.6, n.4, p.313-317, 2002. 
KIM, I.Y.; SEO, S.J.; MOON, H.S.; YOO, M.K.; PARK, I.Y.; KIM, B.C.; CHO, C.S. Chitosan and its derivatives for tissue engineering applications. Biotechnology Advances, v.26, n.1, p.1-21, 2008.

KITAGAWA, T.; YABUKI, K. Physical properties of silk fibroin/chitosan blend films. Journal of Applied Polymer Science, v.80, n.7, p.928-934, 2001.

KOKUBO, T.; TAKADAMA, H. How useful is SBF in predicting in vivo bone bioactivity? Biomaterials, v.27, n.1, p.2907-2915, 2006.

KUBISZ, L.; POLOMSKA, M. FT NIR Raman studies on irradiated bone. Spectrochimica Acta, Part A: Molecular and Biomolecular Spectroscopy, v.66, n.3, p.616-625, 2007.

KUMAR, M.N.V.R. A review of chitin and chitosan applications. Reactive \& Functional Polymers, v.46, n.1, p.1-27, 2000.

LEHNINGER, A.L.; NELSON, D.L.; COX, M.M. Lehninger principles of biochemistry. 5.ed. New York: W.H. Freeman, 2008. 1158p.

LEIRNER, A.A.; TATTINI Jr., V.; PITOMBO, R.M.N. Prospects in Lyophilization of bovine pericardium. Artificial Organs, v.33, n.3, p.221-229, 2009.

LI, M.; TAO, W.K.S.; NISHIYAMA, Y. Controlling molecular conformation of regenerated wild silk fibroin by aqueous ethanol treatment. Polymers for Advanced Technologies, v.14, n.10, p.694-698, 2003.

MADIHALLY, S.V.; MATTHEW, H.W.T. Porous chitosan scaffolds for tissue engineering. Biomaterials, v.20, n.12, p.1133-1142, 1999.

MAIZATO, M.J.; HIGA, O.Z.; MATHOR, M.B.; CAMILLO, M.A.; SPENCER, P.J.; PITOMBO, R.N.; ZAVAGLIA, C.A.; LEIRNER, A.A. Glutaraldehyde-treated bovine pericardium: effects of lyophilization on cytotoxicity and residual aldehydes. Artificial Organs, v.27, n.8, p.692-694, 2003. 
MELLO, K.G.P.C.; BERNUSSO, L.C.; PITOMBO, R.N.M.; POLAKIEWICZ, B. Synthesis and physicochemical characterization of chemically modified chitosan by succinic anhydride. Brazilian Archives of Biology and Technology, v.49, n.4, p.665-668, 2006.

MIKROULIS, D.; MAVRILAS, D.; KAPOLOS, J.; KOUTSOUKOS, P.G.; LOLAS C. Physicochemical and microscopical study of calcific deposits from natural and bioprosthetic heart valves. Comparison and implications for mineralization mechanism. Journal of Materials Science: Materials in Medicine, v.13, n.9, p.885 - 889, 2002.

MOHAMED, F.; BRADLEY, D.A.; WINLOVE, C.P. Effects of ionizing radiation on extracellular matrix. Nuclear Instruments and Methods in Physics Research, Section A, v.580, p.566-569, 2007.

MONTI, P.; FREDDI, G.; SAMPAIO, S.; TSUKADA, M.; TADDEI, P. Structure modifications induced in silk fibroin by enzymatic treatments: a Raman study. Journal of Molecular Structure, v.744-747, p.685-690, 2005.

MURRAY, R.K.; GRANNER, D.K.; MAYES, P.A.; RODWELL, V.W. Harper's biochemistry. 26.ed. London: Prentice-Hall Internacional, 2000. 866p.

NAIMARK, W.A.; LEE, J.M.; LIMEBACK, H.; CHEUNG, D.T. Correlation of structure and viscoelastic properties in the pericardia of four mammalian species. American Journal of Physiology: Heart and Circulatory Physiology, v.263, p.1095-1106, 1992.

NOGUEIRA, G.M. Hidrogéis e filmes de fibroína de seda para a fabricação ou recobrimento de biomateriais. Campinas, 2009. 150p. Tese de Doutorado Faculdade de Engenharia Química - Universidade Estadual de Campinas.

O'BRIEN, F.J.; HARLEY, B.A.; YANNAS, I.V.; GIBSON, L. Influence of freezing rate on pore structure in freeze-dried collagen-GAG scaffolds. Biomaterials, v.25, n.6, p.1077-1086, 2004. 
OETJEN, G.W.; HASELEY, P. Freeze-drying. 2.ed. Weinheim: Wiley-VCH, 2004. 395p.

OHRI, R.; HAHN, S.K.; HOFFMAN, A.S.; STAYTON, P.S.; GIACHELLI, C.M. Hyaluronic acid grafting mitigates calcification of glutaraldehyde-fixed bovine pericardium. Journal of Biomedical Materials Research, Part A, v.70, n.2, p.328334, 2004.

ORÉFICE, R.L.; PEREIRA, M.M.; MANSUR, H.S. Biomateriais: fundamentos e aplicações. Rio de Janeiro: Cultura Médica; 2006. 538p.

ORREGO, C.E.; SALGADO, N.; VALENCIA, J.S.; GIRALDO, G.I.; GIRALDO, O.H.; CARDONA, C.A. Novel chitosan membranes as support for lipases immobilization: characterization aspects. Carbohydrate Polymers, v.79, n.1, p.916, 2010.

PARK, J.B.; BRONZINO, J.D., eds. Biomaterials: principles and applications. 2.ed. Boca Raton: CRC Press, 2003. 250p.

PATAPOFF, T.W.; OVERCASHIER, D.E. The importance of freezing on Iyophilization cycle development. BioPharm, v.15, n.3, p.16-21, 2002.

PREGHENELLA, M.; PEZZOTTI, G.; MIGLIARESI C. Comparative Raman spectroscopic analysis of orientation in fibers and regenerated films of Bombyx mori silk fibroin. Journal of Raman Spectroscopy, v.38, n.5, p.522-536, 2007.

RATNER, B.D.; HOFFMAN, A.S.; SCHOEN, F.J.; LEMONS, J.E., eds. Biomaterials science: an introduction to materials in medicine. 2.ed. Amsterdam: Elsevier Academic Press, 2004. 851p.

RIEDER, E.; NIGISCH, A.; DEKAN, B.; KASIMIR, M.T.; MÜHLBACHER, F.; WOLNER, E.; SIMON, P.; WEIGEL, G. Granulocyte-based immune response against decellularized or glutaraldehyde cross-linked vascular tissue. Biomaterials, v.27, n.33, p.5634-5642, 2006.

ROBERTS, G.A.F. Chitin chemistry. Hampshire: Macmillan Press, 1992. 350p. 
RODAS, A.C.D. Desenvolvimento de membranas como compostos dermoepidérmicos. São Paulo, 2004. 149p. Tese de Doutorado - Instituto de Pesquisas Energéticas e Nucleares.

RODAS, A.C.D.; MAIZATO, M.J.S.; LEIRNER, A.A.; PITOMBO, R.N.M.; POLAKIEWICZ, B.; BEPPU, M.M.; HIGA, O.Z. Cytotoxicity and genotoxicity of bovine pericardium preserved in glycerol. Artificial Organs, v.32, n.4, p.272-276, 2008.

SCHOEN, F.J.; LEVY, R.J. Calcification of tissue heart valve substitutes: progress toward understanding and prevention. Annals of Thoracic Surgery, v.79, n.3, p.1072-1080, 2005.

SCHRADER, B. Infrared and Raman spectroscopy: methods and applications. Weinheim: VCH, 1995. 787p.

SEARLES, J.A.; CARPENTER, J.F.; RANDOLPH, T.W. Annealing to optimize the primary drying rate, reduce freeze-induced drying rate heterogeneity, and determine T'g in pharmaceutical lyophilization. Journal of Pharmaceutical Sciences, v.90, n.7, p.872-887, 2001.

SERVOLI, E.; MANIGLIO, D.; MOTTA, A.; PREDAZZER, R.; MIGLIARESI, C. Surface properties of silk fibroin films and their interaction with fibroblasts. Macromolecular Bioscience, v.5, n.12, p.1175-1183, 2005.

SHAO, J.; ZHENG, J.; LIU, J.; CARR, C.M. Fourier Transform Raman and Fourier Transform Infrared spectroscopy studies of silk fibroin. Journal of Applied Polymer Science, v.96, n.6, p.1999-2004, 2005.

MCGINNISS, V.D. Cross-linking with radiation. In: ENCYCLOPEDIA of Polymer Science and Engineering. New York: John Wiley, 1985. v.4, p.418-449.

SILVA, H.C.; SANTOS, K.S.C.R.; FERREIRA, E.I. Quitosana: derivados hidrossolúveis, aplicações farmacêuticas e avanços. Química Nova, v.29, n.4, p.776-785, 2006. 
SIMIONESCU, D.; SIMIONESCU, A.; DEAC, R. Mapping of glutaraldehydetreated bovine pericardium and tissue selection for bioprosthetic heart valves. Journal of Biomedical Materials Research, v.27, n.6, p.697-704, 1993.

SIRICHAISIT, J.; BROOKES, V.; YOUNG, R.J.; VOLLRATH, F. Analysis of structure/property relationships in silkworm (Bombyx mori) and spider dragline (Nephila edulis) silks using Raman spectroscopy. Biomacromolecules, v.4, n.2, p.387-394, 2003.

SOMESSARI, S.L.; SILVEIRA, C.G.; PAES, H.; SOMESSARI, E.S.R. Electron beam accelerator facilities at IPEN-CNEN/SP. In: INTERNATIONAL NUCLEAR ATLANTIC CONFERENCE (INAC), Santos, 2007. Abstracts. Santos: ASSOCIAÇÃO BRASILEIRA DE ENERGIA NUCLEAR 2007. 1 DVD.

STARR, A.; FESSLER, C.L.; GRUNKEMEIER, G.; HE, W.G. Heart valve replacement surgery: past, present and future. Clinical and Experimental Pharmacology and Physiology, v.29, n.8, p.735-738, 2002.

SUGRANES, J.A. Basic operating principles and validation of electron beam irradiation. Journal of Validation Technology, v.12, n.1, 2005. Disponível em: http://www.gxpandjvt.com/IVTNews/templates/IVTNews.aspx?articleid=1440\&z oneid=18. Acesso em: 07 jul. 2009.

SWALLOW, A.J. Radiation chemistry of organic compounds. Oxford, New York: Pergamon Press, 1960. 380p. (International Series of Monographs on radiation effects in materials, v.2).

TATTINI Jr., V.; MATOS, J.R.; POLAKIEWICZ, B.; PITOMBO, R.N.M. Evaluation of shrinkage temperature of bovine pericardium tissue for bioprosthetic heart valve application by differential scanning calorimetry and freeze-drying microscopy. Materials Research, v.10, n.1, p.1-4, 2007.

LABANA, S.S. Cross-linking. In: ENCYCLOPEDIA of Polymer Science and Engineering. New York: John Wiley, 1985. v.4, p.350-395. 
TRANTINA-YATES, A.E.; HUMAN, P.; BRACHER, M.; ZILLA, P. Mitigation of bioprosthetic heart valve degeneration through biocompatibility: in vitro versus spontaneous endothelialization. Biomaterials, v.22, n.13, p.1837-1846, 2001.

TSUKADA, M.; FREDDI, G.; MASSAFRA, M.R.; BERETTA, S. Structure and properties of tussah silk fibers graft-copolymerized with methacrylamide and 2hydroxyethyl methacrylate. Journal of Applied Polymer Science, v.67, n.8, p.1393-1403, 1998.

TSUKADA, M.; FREDDI, G.; MONTI, P.; BERTOLUZZA, A.; KASAI, N. Structure and molecular conformation of tussah silk fibroin films: effect of methanol. Journal of Polymer Science, Part B: Polymer Physics, v.33, n.14, p.1995-2001, 1995.

VANDEVORD, P.J.; MATTHEW, H.W.; DESILVA, S.P.; MAYTON, L.; WU, B.; WOOLEY, P.H. Evaluation of the biocompatibility of a chitosan scaffold in mice. Journal of Biomedical Materials Research, v.59, n.3, p.585-590, 2002.

VANKEIRSBILCK, T.; VERCAUTEREN, A.; BAEYENS, W.; VAN DER WEKEN, G.; VERPOOR, F.; VERGOTE, G.; REMON, J.P. Applications of Raman spectroscopy in pharmaceutical analysis. Trends in Analytical Chemistry, v.21, n.12, p.869-877, 2002.

VASCONCELOS, H.L.; CAMARGO, T.P.; GONÇALVES, N.S.; NEVES, A.; LARANJEIRA, M.C.M.; FÁVERE, V.T. Chitosan crosslinked with a metal complexing agent: synthesis, characterization and copper (II) ions adsorption. Reactive \& Functional Polymers, v.68, n.2, p.572-579, 2008.

VITALI, L.; LARANJEIRA, M.C.M.; FÁVERE, V.T. Microencapsulação do agente quelante sulfoxina em microesferas de quitosana preparadas por spray drying como novo adsorvente para íons metálicos. Química Nova, v.31, n.6, p.1400-1404, 2008.

WOODS, R.J.; PIKAEV, A.K. Applied radiation chemistry: radiation processing. New York: Wiley Interscience, 1994. 535p. 